UNIVERSIDADE DE SÃO PAULO

FACULDADE DE ARQUITETURA E URBANISMO

ALINE DA SILVA ESCÓRCIO RIBEIRO

ELEMENTOS DA CULTURA POPULAR NA OBRA DE LINA BO BARDI SESC POMPÉIA E IGREJA DO ESPÍRITO SANTO DO CERRADO 



\title{
ELEMENTOS DA CULTURA POPULAR NA OBRA DE LINA BO BARDI SESC POMPÉIA E IGREJA DO ESPÍRITO SANTO DO CERRADO
}

\author{
Dissertação apresentada à Faculdade de \\ Arquitetura e Urbanismo da Universidade de São \\ Paulo para obtenção do título de Mestre em \\ Arquitetura e Urbanismo \\ Área de Concentração: Projeto, Espaço e Cultura \\ Orientador: Prof. Dr. Luís Antônio Jorge
}

São Paulo, 2016

EXEMPLAR REVISADO E ALTERADO EM RELAÇÃO À VERSÃO ORIGINAL, SOB RESPONSABILIDADE DO AUTOR E ANUÊNCIA DO ORIENTADOR.

$O$ original se encontra na sede do programa

São Paulo, 29 de junho de 2016 
AUTORIZO A REPRODUÇÃO E DIVULGAÇÃO TOTAL OU PARCIAL DESTE TRABALHO, POR QUALQUER MEIO CONVENCIONAL OU ELETRÔNICO, PARA FINS DE ESTUDO E PESQUISA, DESDE QUE CITADA A FONTE.

E-MAIL DA AUTORA: aline-e@usp.br

Ribeiro, Aline da Silva Escórcio

R484e Elementos da cultura popular na obra de Lina Bo Bardi. SESC

Pompéia e Igreja do Espírito Santo do Cerrado / Aline da Silva

Escórcio Ribeiro. -- São Paulo, 2016.

160 p. : il.

Dissertação (Mestrado - Área de Concentração: Projeto, Espaço e Cultura) - FAUUSP.

Orientador: Luís Antônio Jorge

1.Arquitetura moderna - Brasil 2.Cultura popular 3.Bardi, Lina Bo 1914-1992 I.Título 
FOLHA DE APROVAÇÃO

Nome: Aline da Silva Escórcio Ribeiro

Título: Elementos da cultura popular na obra de Lina Bo Bardi - SESC Pompéia e Igreja do Espírito Santo do Cerrado

Dissertação apresentada a Faculdade de Arquitetura e Urbanismo da Universidade de São Paulo para obtenção do título de Mestre em Arquitetura e Urbanismo

Área de Concentração: Projeto, Espaço e Cultura

Orientador: Prof. Dr. Luís Antônio Jorge

Aprovado em:

Banca Examinadora

Prof. Dr. Instituição:

Assinatura: Julgamento:

Prof. Dr. Instituição:

Assinatura: Julgamento:

Prof. Dr. Instituição:

Assinatura: Julgamento: 



\section{AGRADECIMENTOS}

Ao professor Luís Antônio Jorge pela orientação, e sobretudo pela paciência e confiança.

Aos professores Mônica Junqueira e Marcelo Suzuki pelos valiosos comentários durante o exame de qualificação. À professora Fernanda Fernandes, pelas importantes conversas no início deste percurso. Aos professores da Faculdade de Arquitetura e Urbanismo da Universidade de São Paulo pelo ensino de qualidade na Graduação e na Pós-Graduação.

Aos pesquisadores que se dedicam à obra de Lina Bo Bardi por compartilharem seus conhecimentos e descobertas.

Ao Instituto Lina Bo e Pietro Maria Bardi pela disponibilização dos materiais.

Aos meus pais, Zélia e Francisco, por toda dedicação, pelo apoio e confiança, e por compartilharem comigo a paixão pela docência.

À Ariane, pela profunda amizade, pelas leituras e pelo incentivo constante.

Ao Leandro, pela companhia e apoio incondicional.

À Fátima, Miguel e Maurício pelo apoio.

Em especial aos amigos da FAU e de sempre, Andrea Conard, Andrea Erdos, Carolina Pedrosa, Gabriel Rossi, Higor Carvalho, Itala Bonatelli, Juliana Cipolletta, Luciana Romão, Maíra Baltrusch, Paula Flumian, Raphael Souza, Sofia Sterzi, Tadeu Binsztajn.

Aos demais familiares, amigos, colegas de trabalho e todos aqueles que me incentivaram, apoiaram e compreenderam minhas ausências.

Aos meus alunos, pelo aprendizado diário que me proporcionam. 

à memória dos meu avós 

"Respeite o mandacaruzinho ao lado."

Lina Bo Bardi 



\section{RESUMO}

Esta dissertação estabelece uma leitura sobre os projetos de Lina Bo Bardi para o Sesc Pompéia e para a Igreja do Espírito Santo do Cerrado a partir de sua relação com a cultura popular. A investigação atravessa três importantes períodos no percurso profissional da arquiteta. Inicia na origem de seu olhar sobre a cultura popular na Itália em um contexto de revisão da modernidade no período entre guerras e no imediato pós Segunda Guerra Mundial. Passa por seus primeiros anos de atuação no Brasil, sobretudo entre São Paulo e Bahia, durante o período de abertura política em um contexto de coexistência entre a formação de uma modernidade nacional e a crescente atenção e valorização da cultura popular por parte de diversos artistas e intelectuais. Por fim atinge o período de produção cuja base interpretativa sobre a cultura popular, formulada ao longo dos anos, possibilitou a geração de elementos na arquitetura capazes de estabelecer uma comunicação direta com os usuários de forma familiar e poética, caracterizando a peculiaridade dos projetos de Lina Bo Bardi dentro do cenário da arquitetura brasileira.

Palavras-chave: Lina Bo Bardi. Cultura Popular. Arquitetura moderna - Brasil. 



\section{ABSTRACT}

This work establishes a read on the project of Lina Bo Bardi to the SESC Pompéia and the Igreja do Espírito Santo do Cerrado from its relationship with popular culture. Research through three major periods in the professional architect route. Starts at the origin of his gaze on popular culture in Italy in a context of the revision of the modernity in the interwar period and after World War II. Goes through its first years of operations in Brazil, especially in São Paulo and Bahia, during the period of political opening in a context of coexistence between the formation of a national modernity and the increasing attention and appreciation of popular culture by various artists and intellectuals. Finally reaches the production period whose interpretation based on popular culture, formulated over the years, enabled the creation of elements in the architecture capable of establishing a direct communication with the users in a poetic and familiar way, featuring the peculiarity of Lina Bo Bardi projects inside the Brazilian architecture scene.

Keywords: Lina Bo Bardi. Popular Culture. Modern architecture - Brazil. 

LISTA DE FIGURAS

Figura 1

Figura 2

Figura 3

Figura 4

Figura 5-6

Figura 7-12

Figura 13

Figura 14

Figura 15

Figura 16

Figura 17

Figura 18

Figura 19

Figura 20

Figura 21

Figura 22

Figura 24

Figura 25-26

Figura 27-32

Figura 33-34

Figura 35-40

Figura 41

Figura 42

Figura 43

Figura 44

Figura 45

Figura 46

Figura 47

Figura 48

Figura 49

Figura 50
Pintura de Umberto Boccioni "The city rises"

Série de pinturas de Umberto Boccioni "States of mind I", "States of mind II" e "States of mind III"

Ilustração de Antonio Sant'Elia "Città Nuova"

Manifesto "L’architettura Futurista" de Sant'Elia, 1914

"Documenti di Arquitettura Rurale", Giuseppe Pagano

"Documenti di Arquitettura Rurale", Giuseppe Pagano

Capa da revista Casabella no 95

Mostra "Achitettura Rurale Italiana" na IV Trienal de Milão, 1936

Capa do catálogo da mostra "Archittetura Rurale Italiana"

Capas da revista Domus

Páginas internas da revista Domus

Reitoria da Cittá Universitaria di Roma, projeto de

Marcello Piacentini

Instituto de Matemática da Cittá Universitaria di Roma, projeto de Gio Ponti

Artigos escritos e ilustrados por Lina e Pagani para a revista Grazia, 1941

Páginas da revista Domus digirida por Lina e Pagani, 1943

Revista A - Cultura della vita no2

Lina Bo e Pietro Maria Bardi, 1946

“Case Rurale”, Giuseppe Pagano

“Case Rurale”, Giuseppe Pagano

"Arquitettura rurale in Italia", Giuseppe Pagano

"Arquitettura rurale in Italia", Giuseppe Pagano

Pinacoteca do Museu de Arte de São Paulo, 1950

Auditório do Museu com cadeira projetadas pelo Studio Palma

Cadeiras do auditório empilhadas

Capa da revista Habitat $\mathrm{n}-1$

Páginas da revista Habitat $\mathrm{n}$ ㅇ 1

Família de ceramistas

Escultura de cerâmica "Família do nordeste"

Escultura de cerâmica "Ao mercado"

"Vaso de flores, executado por caboclos do Ceará"

Redes dos "navios gaiola"
FRAQUELLI, 2014, p.83 pag. 15

SALARIS, 2014, p.27 pag. 15

ISGRO, 2014, p.140 pag. 16

MEYER, 2014, p.143 pag. 16

CASABELLA, $\mathrm{n}$ 오으, 1935, p.18-19

pag. $22-23$

CASABELLA, n95, 1935, p.20-25

pag. $24-25$

pag. 25

1935

SABATINHO, 2012,

p.132

pag. 26

BONOMETTO, 2005

pag. 26

PONTI, 1990

pag. 27

PONTI, 1990

pag. 27

COHEN, 2013, p.274

pag. 29

PONTI, 1990, p.67

pag. 29

FERRAZ, 1993, p.28

pag. 34

FERRAZ, 1993, p.29

pag. 35

FERRAZ, 1993, p.30

pag. 34-35

FERRAZ, 1993, p.37

pag. 40

CASABELLA, n으,

1935, p.8-9

pag. 51

CASABELLA, n86, 1935, p.10-15

pag. 52-53

CASABELLA, no 96 , dez. 1935, p. 16-17

pag. $54-55$

CASABELLA, no 96,

dez. 1935 , p. 18-23

pag. 56-57

FERRAZ, 1993, p.47

pag. 67

FERRAZ, 1993, p.50

pag. 67

FERRAZ, 1993, p.50

pag. 67

FERRAZ, 1993, p.64

pag. 68

FERRAZ, 1993, p.64

pag. 68

HABITAT, 1951, p.72

pag. 74

HABITAT, 1951, p.75

pag. 74

HABITAT, 1951, p.74

pag. 74

HABITAT, 1951, p.55

pag. 75

HABITAT, 1950, p.55 pag. 77 


\begin{tabular}{|c|c|c|c|c|}
\hline Figura 51 & Cadeira tripé em madeira inspirada nas redes & HABITAT, 1950, p.55 & pag. & 77 \\
\hline Figura 52-53 & Cadeiras desenhadas e executadas no Studio Palma & HABITAT, 1950, p.56 & pag. & 77 \\
\hline Figura 54 & $\begin{array}{l}\text { Projeto de interiores para um restaurante em São Paulo, } \\
\text { Lina Bo Bardi, } 1950\end{array}$ & HABITAT, 1951, p.30 & pag. & 78 \\
\hline Figura 55-56 & Páginas no artigo "Desenho Industrial” & $\begin{array}{l}\text { HABITAT, 1951, p.62- } \\
63\end{array}$ & pag. & 78 \\
\hline Figura 57 & Página no artigo "Dois objetos" & $\begin{array}{l}\text { HABITAT, 1951, p.62- } \\
63\end{array}$ & pag. & 79 \\
\hline Figura 58 & Vista externa da "Casa de 7 mil cruzeiros" & HABITAT, 1951, p.4 & pag. & 83 \\
\hline Figura 59 & Família moradora da "Casa de 7 mil cruzeiros" & HABITAT, 1951, p.4 & pag. & 83 \\
\hline Figura 60 & Vista interna da "Casa de 7 mil cruzeiros" & HABITAT, 1951, p.5 & pag. & 83 \\
\hline Figura 61 & Vista externa da casa de José da Silva e Matto & HABITAT, 1952, p.3 & pag. & 84 \\
\hline Figura 62-63 & Processo construtivo da casa de José da Silva e Matto & HABITAT, 1952, p.3-5 & pag. & 84 \\
\hline Figura 64 & Casa na beira de uma estrada em Belém & HABITAT, 1952, p.47 & pag. & 85 \\
\hline Figura 65 & Casa na beira do rio em "Amazonas o povo arquiteto" & HABITAT, 1950, p.68 & pag. & 85 \\
\hline Figura 66 & Casa em "O povo é arquiteto" & HABITAT, 1953, p.52 & pag. & 85 \\
\hline Figura 67-68 & Produção em série feita pelo povo & FERRAZ, 1993, p.89 & pag. & 103 \\
\hline Figura 69 & $\begin{array}{l}\text { Página do primeiro número de "Crônicas de arte, de } \\
\text { história, de costume, de cultura da vida" }\end{array}$ & FERRAZ, 1993, p.130 & pag. & 104 \\
\hline Figura 70 & Conjunto do Unhão após a restauração, 1963 & FERRAZ, 1993, p.153 & pag. & 105 \\
\hline Figura 71 & Conjunto do Unhão antes da restauração, 1959 & FERRAZ, 1993, p.153 & pag. & 105 \\
\hline Figura 72 & Escada do conjunto do Unhão & FERRAZ, 1993, p.157 & pag. & 105 \\
\hline Figura 73-74 & Exposição “Bahia no Ibirapuera”, 1959 & FERRAZ, 1993, p.135 & pag. & 111 \\
\hline Figura 75 & $\begin{array}{l}\text { Lina Bo Bardi na montagem da exposição "Bahia" no } \\
\text { lbirapuera }\end{array}$ & FERRAZ, 1993, p.134 & pag. & 111 \\
\hline Figura 76 & Exposição “Carrancas do São Francisco" & FERRAZ, 1993, p.140 & pag. & 112 \\
\hline Figura 77 & Exposição de cristais gigantes "Formas Naturais" & FERRAZ, 1993, p.138 & pag. & 112 \\
\hline Figura 78 & Exposição "Bailarinas" de Degas & FERRAZ, 1993, p.139 & pag. & 112 \\
\hline Figura 79 & Cartaz da exposição "Nordeste" no MAMB, 1963 & FERRAZ, 1993, p.158 & pag. & 113 \\
\hline Figura $80-83$ & Exposição “Nordeste" no MAMB, 1963 & FERRAZ, 1993, p.159 & pag. & 113 \\
\hline Figura 84 & Igreja do Espírito Santo do Cerrado após a construção & FERRAZ, 1993, p.215 & pag. & 131 \\
\hline Figura 85-86 & Igreja de tábuas & FERRAZ, 1999 & pag. & 131 \\
\hline Figura 87 & Lina em reunião para definições de projeto & FERRAZ, 1999 & pag. & 131 \\
\hline Figura 88 & $\begin{array}{l}\text { SESC Pompéia após a restauração dos galpões e } \\
\text { construção das novas torres }\end{array}$ & FERRAZ, 1993, p.220 & pag. & 132 \\
\hline Figura 89 & $\begin{array}{l}\text { Vista do conjunto da fábrica da Pompéia antes da } \\
\text { reforma }\end{array}$ & OLIVEIRA, 2007, p.16 & pag. & 132 \\
\hline Figura 90 & Utilização do galpão da fábrica antes do restauro & OLIVEIRA, 2007, p.22 & pag. & 132 \\
\hline Figura 91 & "Festa de Noantri in Trestevere" - Lina Bo Bardi, 1929 & FERRAZ, 1993, p.18 & pag. & 134 \\
\hline Figura 92 & “Piazza Guglielmo Pepe” - Enrico Bo & FERRAZ, 1993, p.33 & pag. & 134 \\
\hline Figura 93 & Figurinos para peça de teatro - Gio Ponti, 1939 & GIOPONTI.org & pag. & 134 \\
\hline Figura 94 & $\begin{array}{l}\text { Aquarelas de Lina Bo Bardi para estudo do projeto para } \\
\text { a Igreja do Espírito Santo do Cerrado }\end{array}$ & FERRAZ, 1993, p.211 & pag. & 135 \\
\hline Figura 95 & $\begin{array}{l}\text { Aquarelas de Lina Bo Bardi para estudo do projeto para } \\
\text { o SESC Pompéia }\end{array}$ & FERRAZ, 1993, p.211 & pag. & 135 \\
\hline
\end{tabular}




\begin{tabular}{|c|c|c|c|}
\hline Figura 96 & Planta e Elevação da Igreja do Espírito Santo do Cerrado & FERRAZ, 1993, p.221 & pag. \\
\hline Figura 97-99 & Paredes curvas da igreja em construção & FERRAZ, 1999 & pag. \\
\hline Figura 100 & Vista dos telhados da igreja & FERRAZ, 1999 & pag. \\
\hline Figura 101 & Centro comunitário & FERRAZ, 1993, p.213 & pag. \\
\hline Figura 102 & Planta e Cortes do SESC Pompéia & FERRAZ, 1993, p.222 & pag. \\
\hline Figura 103 & Rua central de acesso ao conjunto do SESC Pompéia & SUZUKI, 2010, p.145 & pag. \\
\hline Figura 104 & $\begin{array}{l}\text { "Praia" e blocos esportivos ao fundo com suas janela } \\
\text { buraco }\end{array}$ & FERRAZ, 1993, p.230 & pag. \\
\hline Figura 105 & Galpão com atividades em diferentes níveis & OLIVEIRA, 2014, p.134 & pag. \\
\hline Figura 106 & "Rio São Francisco" e lareira ao fundo & $\begin{array}{l}\text { LATORRACA, 1999, } \\
\text { p.79 }\end{array}$ & pag. \\
\hline Figura 107-110 & Igreja do Espírito Santo do Cerrado em construção & FERRAZ, 1999 & pag. \\
\hline Figura 111 & Detalhe da construção da caixa d'água do SESC Pompéia & OLIVEIRA, 2007, p.95 & pag. \\
\hline Figura 112 & $\begin{array}{l}\text { Placa do restaurante desenhada por Lina e executada } \\
\text { pelo marceneiro da obra }\end{array}$ & OLIVEIRA, 2007, p.77 & pa \\
\hline
\end{tabular}




\section{LISTA DE SIGLAS}

$\begin{array}{ll}\text { CEAO } & \text { Centro de Estudos Afro-Orientais } \\ \text { CPC } & \text { Centro Popular de Cultura } \\ \text { FAAUSP } & \text { Faculdade de Arquitetura e Urbanismo da Universidade de São Paulo } \\ \text { IAB } & \text { Instituto de Arquitetos do Brasil } \\ \text { MAMB } & \text { Museu de Arte Moderna da Bahia } \\ \text { MASP } & \text { Museu de Arte de São Paulo } \\ \text { MAUC } & \text { Museu de Arte da Universidade Federal do Ceará } \\ \text { MCP } & \text { Movimento de Cultura Popular } \\ \text { TCA } & \text { Teatro Castro Alves } \\ \text { UFBA } & \text { Universidade Federal da Bahia } \\ \text { UNE } & \text { União Nacional dos Estudantes } \\ \text { UNESCO } & \text { United Nations Educational, Scientific and Cultural Organization }\end{array}$


SUMÁRIO

INTRODUÇÃO

CAPÍTULO 1 - FORMAÇÃO DO OLHAR

1.1. O LUGAR DA CULTURA POPULAR NO RACIONALISMO ITALIANO

O RACIONALISMO A PARTIR DE CROCE

UMA MODERNIDADE PLURAL

O DEBATE ATRAVÉS DAS REVISTAS CASABELLA E DOMUS

1.2. INTERLOCUÇÕES

PARTICIPAÇÃO NOS EDITORIAIS

O TRABALHO COM GIO PONTI

A INFLUÊNCIA DA LEITURA DE GRAMSCI 37

O ENCONTRO COM PIETRO MARIA BARDI

1.3. OS PRINCÍPIOS DE LEITURA SOBRE A CULTURA POPULAR

ARQUITETURA PARA A VIDA DO HOMEM

O COTIDIANO COMO CONSTRUÇÃO PERMANENTE DA HISTÓRIA 44

O SABER FAZER

A ARQUITETURA MENOR

CAPÍTULO 2 - CONSOLIDAÇÃO

2.1. CHEGADA AO BRASIL

61

2.2. A CULTURA POPULAR NA REVISTA HABITAT 64

ARTE E ARQUITETURA PARA A VIDA DO HOMEM 69

A PRESENÇA DA CULTURA POPULAR 71

A PRODUÇÃO DE LINA NA REVISTA 76

ARQUITETURA POPULAR 80

A FORMULAÇÃO DE UMA DIDÁTICA 86

2.3. OLHO SOBRE A BAHIA 91

HISTÓRIA E PRESERVAÇÃO 93

PRENÚNCIO DAS AÇÕES 98

PESQUISA SOBRE OS OBJETOS POPULARES 
2.4. BASES PARA A INTERPRETAÇÃO DA CULTURA POPULAR 115

$\begin{array}{ll}\text { ARTE E ARQUITETURA PARA A VIDA DO HOMEM } & 116\end{array}$

O COTIDIANO COMO CONSTRUÇÃO DA HISTÓRIA 116

$\begin{array}{ll}\text { O SABER FAZER } & 117\end{array}$

CAPÍTULO 3 - INVEÇÃO DA MEMÓRIA - SESC POMPÉIA E IGREJA DO ESPÍRITO SANTO DO CERRADO

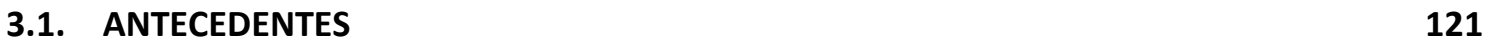

3.2. PREMISSAS PARA DOIS PROJETOS DE LINA BO BARDI 127

$\begin{array}{ll}\text { IGREJA DO ESPÍRITO SANTO DO CERRADO } & 128\end{array}$

$\begin{array}{ll}\text { SESC POMPÉIA } & 129\end{array}$

3.3. ARQUITETURA PARA A VIDA DO HOMEM 133

$\begin{array}{ll}\text { IGREJA DO ESPÍRITO SANTO DO CERRADO } & 136\end{array}$

$\begin{array}{ll}\text { SESC POMPÉIA } & 138\end{array}$

3.4. PRESENTE HISTÓRICO

$\begin{array}{ll}\text { IGREJA DO ESPÍRITO SANTO DO CERRADO } & 147\end{array}$

$\begin{array}{ll}\text { SESC POMPÉIA } & 148\end{array}$

$\begin{array}{ll}\text { 3.5. O SABER FAZER } & 149\end{array}$

$\begin{array}{ll}\text { ARQUITETURA POBRE } & 149\end{array}$

IGREJA DO ESPÍRITO SANTO DO CERRADO 150

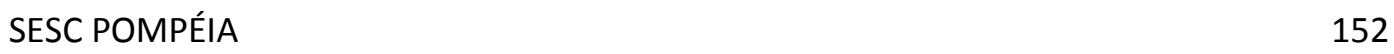

$\begin{array}{ll}\text { CONSIDERAÇõES FINAIS } & 157\end{array}$

$\begin{array}{ll}\text { BIBLIOGRAFIA } & 160\end{array}$ 


\section{INTRODUÇÃO}

O estudo sobre a obra de Lina Bo Bardi, mesmo que bastante explorado nos últimos anos, ainda se mostra como um campo vasto de possibilidades de abordagem. A ampla rede de relações e conhecimentos acumulados ao longo de seus anos de atuação e a complexidade dos arranjos formados para a geração de espaços para a vida tornam os trabalhos da arquiteta ainda mais instigantes. E dizemos espaços para a vida, pois a arquitetura de Lina nunca foi um fato urbano estéril, a interação com a cidade e com os usuários extrapola a burocracia dos programas de necessidades e atinge de forma leve e quase imperceptível a alma de qualquer pessoa.

A esta capacidade de aproximação atribuímos o compromisso com a verdade das construções conferida tanto aos projetos modernos quanto à expressão popular que adota a racionalidade como meio de sobrevivência e a estética como manifestação de sua originalidade. Entendendo a cultura popular como geradora de processos práticos onde os principais agentes são aqueles que não estão inseridos no campo acadêmico, o que propomos aqui é uma leitura atenta sobre elementos dessa cutlura que foram apreendidos, interpretados e incorporados por Lina Bo Bardi em seus projetos.

Para isso, partiremos do contexto de formação da arquiteta na Itália, estabelecendo um breve panorama sobre os acontecimentos formadores do conceito de modernidade em um ambiente de ideologias plurais, e em cuja cultura popular estava inserida como um dado metodológico e estético a ser percebido. A busca pela verdadeira identidade cultural de um país recém unificado fez com que a tradição fosse resgatada a partir de suas raízes mais primitivas, despertando o interesse das diversas vertentes de movimentos artísticos, cada uma a seu modo. Assim, os arquitetos em formação durante os anos de 1930 e 1940 presenciaram um importante debate acerca da racionalidade e dos 
questionamentos sobre o significado da arte, despertando o espírito crítico e observador destes jovens. Ademais, os infelizes resultados das guerras foram determinantes para a busca de significado e da qualidade na simplicidade como forma de superação de uma linguagem e de um modo de operar que não se relacionava mais com as necessidades modernas da sociedade.

Buscou-se, então, nas chamadas artes menores, o valor real da arte a ser estabelecido como princípio para a produção do espaço e dos objetos do uso cotidiano, uma vez que estas manifestações estariam apoiadas na solução de problemas práticos, e com a técnica e a originalidade experimentadas através de gerações. Esta visão, formulada a partir de estudos teóricos, viagens de pesquisa, intensos debates e interlocuções diversas, serviu como base para a construção de um pensamento sobre a modernidade que Lina levou adiante no Brasil. Como um recurso didático para este estudo estabelecemos os princípios de leitura sobre a cultura popular, inerentes a esse processo de formação crítica da arquiteta e que levantam grupos de questões pertinentes ao pensamento sobre a apropriação de métodos populares na produção moderna. Configuram-se: a a rquitetura para a vida do homem, o cotidiano como construção permanente da história, o saber fazer ea arquitetura menor.

Em um segundo momento da trajetória profissional de Lina, dá-se a consolidação desses princípios que são logo transformados em bases para a interpretação da cultura popular. Já no Brasil, este processo é potencializado com os acontecimentos de um período fértil em relação às pesquisas sobre a cultura popular no país. Assim como na Itália, Lina procurou participar intensamente dos debates e das investigações que levaram a uma busca pelo (re)descobrimento das raízes brasileiras. Mais próxima de uma atuação efetiva sobra a cultura nacional, através das atividades no Museu de Arte de São Paulo (MASP) e no Museu de Arte Moderna da Bahia (MAMB), a arquiteta esforçou-se para colocar em prática o intercâmbio entre as chamadas cultura popular e cultura erudita com o intuito de quebrar a barreira entre esses conceitos e contribuir para a formação da cultura moderna de um país cheio de possibilidades.

É durante este período que Lina estabelece o recorte de sua abordagem no campo cultural brasileiro. A aproximação com a origem africana do Nordeste configura o ponto de partida para suas pesquisas sobre a cultura popular, e o sertão torna-se uma referência chave a partir da observação sobre as soluções racionais e originais desenvolvidas por suas populações para suprir as necessidades do cotidiano em um cenário precário e com escassez de recursos. A riqueza desses métodos populares alimenta a esperança na possibilidade do desenvolvimento de um desenho industrial moderno e 
aderente à cultura nacional. Entretanto, os acontecimentos políticos de 1964 interrompem o projeto de um Brasil moderno baseado nas raízes culturais do país empreendido pela arquiteta.

A partir de um momento de desesperança, o repertório crítico de Lina passa então a servir de base para a invenção da memória de um povo que mais do que nunca deveria tomar consciência de sua condição diante das rápidas e drásticas transformações que a sociedade brasileira estava passando. Era o momento de repensar as relações entre os homens e do homem com seu ambiente de vida. O manifesto de Lina ecoou através de suas exposições, seus textos e sobretudo através de sua arquitetura inusitada, questionadora e ao mesmo tempo tão própria para a natural convivência entre as pessoas.

Como primeiro plano para a investigação sobre esses processos, trazemos os casos dos projetos para algreja do Espírito Santo do Cerrado e para o SESC Pompéia como breves amostras da compreensão da cultura popular como método de projeto e como linguagem crítica sobre os valores estéticos e técnicos pré-estabelecidos.

Alguns trabalhos de pesquisa foram fundamentais para a realização deste estudo, uma vez que adotamos como procedimento a investigação sobre os registros bibliográficos como fonte inicial de conhecimento acerca dos pensamentos de Lina sobre a cultura popular e a definição dos elementos de projeto que evidenciam os tópicos dessa discussão. Entre eles está a aprofundada pesquisa de Grinover (2010) sobre os escritos de Lina Bo Bardi; as investigações de Rubino (2002) sobre a modernidade a partir da trajetória da arquiteta; as elaborações de Azevedo (1995) acerca da experiência de Lina no Brasil; a detalhada análise de Oliveira (2006) sobre os elementos peculiares de sua arquitetura; o trabalho de Pereira (2008) acerca do período em que a arquiteta esteve na Bahia; entre outros estudos que seguem referenciados nesta dissertação e olham para a obra da arquiteta, cada um a partir de uma perspectiva particular, e que, mesmo em seu conjunto ainda não desvendam por completo todas as singularidades que compõem a obra de Lina Bo Bardi.

Como contribuição a esse quadro, este trabalho oferece mais uma perspectiva de leitura sobre a obra de Lina e, sobretudo, busca contribuir com a reflexão sobre a possibilidade da adoção de métodos não pasteurizados de produção dos espaços da cidade tomando como exemplo a trajetória e as ações da arquiteta. 

CAPÍTULO 1

FORMAÇÃO DO OLHAR 



\subsection{O LUGAR DA CULTURA POPULAR NO RACIONALISMO ITALIANO}

O desenvolvimento da estética moderna na Itália ocorreu de forma plural entre a teoria e a prática da arquitetura durante as primeiras décadas do século XX. Em meio à tradição clássica, o futurismo, o racionalismo, o Novecento, e todas as outras manifestações que se desenrolaram durante a construção da modernidade italiana, estava a tradição vernacular, alimentando o debate arquitetônico e influenciando em diferentes medidas cada um dos artistas e intelectuais do período.

Os primeiros anos do século XX na Itália marcaram um período de busca pela identidade cultural de um país recém unificado. ${ }^{1}$ As cidades do norte da Itália tiveram sua paisagem rapidamente modificada com o crescimento da indústria após o Risorgimento, e muitos artistas seguiram em um movimento de oposição ao espírito da arte clássica, que por sua vez, remetia a uma política reacionária. Também na arquitetura, onde a produção estava em grande parte vinculada ao poder público, o posicionamento variava de acordo com as posturas políticas adotadas.

\section{O RACIONALISMO A PARTIR DE CROCE}

O início da ideia moderna italiana é associado ao pensamento do filósofo Benedetto Croce (18661952), que através de sua "filosofia do espírito", baseada em Hegel, estabeleceu uma nova visão sobre a concepção da arte. Em um cenário cuja base da crítica amparava-se nos movimentos de vanguarda como uma produção de estética coletiva, a abordagem baseada em Croce voltou a considerar o estudo

\footnotetext{
${ }^{1}$ Em 1861 formou-se o Reino da Itália com anexação de grande parte do território que no decorrer dos anos foi se completando até aproximadamente 1870 com a conquista de Roma
} 
da produção individual, integrando ainda a esta análise o juízo de valor com a distinção do que poderia ou não ser considerado como arte. Seus estudos propunham também a superação de dualismos, como espírito e matéria, vontade e ação, intuição e expressão, pontos que se mostravam mais evidentes na arquitetura do que nas outras artes. ${ }^{2}$

A conciliação entre teoria e prática também foi elaborada pelo filósofo, ainda que em um segundo momento de suas teorias ${ }^{3}$. Para Croce todas as manifestações artísticas carregavam questões técnicas, econômicas e utilitárias, que eram, sobretudo, características determinantes na produção arquitetônica.

\begin{abstract}
Lo importante, escribe, es que un artista no concibe nunca su obra en el vacío sino siempre en el lleno, es decir, en determinadas condiciones y presupuestos, entre los que están también (al menos en todas las obras de arte de una cierta complejidad) sus necesidades él hace suyas. El trabajo del artista no se ve impedido, ni puede ser impedido, por estos presupuestos, porque entre materia y forma no hay contradicción... El poeta imagina con el presupuesto de las palabras de du pueblo, con el conocimiento de ciertas disposiciones de su ambiente, etcétera; el arquitecto imagina según aquellas piedras, aquel terreno, aquel espacio dado, aquellas exigencias de vida. ${ }^{4}$
\end{abstract}

Desse modo, tomou-se como premissa o fato de que a atenção às condições ambientais para a criação da arte, em especial para a criação da arquitetura, contribuía para que o artista/arquiteto não se desvinculasse das questões reais a serem resolvidas pela pura execução da arte pela arte. Ele trabalharia a partir das condições pré-determinadas e, junto a isto, integraria seu espírito individual de criação imprimindo um caráter original a solução dos problemas impostos.

Esta originalidade, por sua vez, surgiria a partir da combinação entre um dado histórico e uma nova ideia para resolver determinadas questões. Então, ao operar sobre a fusão dessas duas esferas, entre o velho e o novo, o artista se tornaria capaz de estabelecer a comunicação com todos. ${ }^{5}$

\footnotetext{
2 DE FUSCO, Renato. La idea de arquitectura - historia de la critica desde Viollet-le-duc a Persico. Barcelona: Editorial Gustavo Gili, 1976. p.182

${ }^{3}$ Conforme De Fusco (1976, p.182), a primeira estética crociana considerava a autonomia do espírito da arte diante da prática. Tal consideração fez com que a crítica ao seu trabalho questionasse sobre um possível pensamento contraditório em seus estudos. Entretanto, a reformulação desta ideia é publicada dois anos depois de sua primeira Estética., de 1902.

${ }^{4}$ CROCE, 1946, p.80-81 apud DE FUSCO, 1976, p.183

${ }^{5}$ Este arranjo é fundamental na obra de Lina Bo Bardi em relação a identificação entre suas obras e os usuários como vemos mais adiante.
} 
Cuando el artista ha formado su imagen, aquel lenguaje anterior, aquella sintaxis, aquella métrica, aquella psicología, etcétera, es decir, toda aquella historia, están ya dentro de la nueva imagen; existen, pero, al mismo tiempo, ya están superadas por la nueva imagen: la lengua es la vieja lengua, y sin embargo nueva; el metro es el viejo metro, y sin embargo tiene un movimiento nuevo; se habla a los demás hombres en modos que les son familiares, pero también aun no familiares, porque aquella poesía es, al mismo tiempo, vieja y nueva. ${ }^{6}$

Outro ponto relevante nos estudos do filósofo, e compatível com as ideias do Movimento Moderno arquitetônico, é a relação entre ética e estética na arte diretamente vinculada à técnica. "Según Croce la técnica propiamente dicha es un conjunto de nociones y operaciones destinadas a la fijación practica de aquella imagen que el artista ya ha formado claramente dentro de sí."7 Desse modo, haveria uma "técnica interior" ao artista capaz de responder às questões fornecidas para a execução de determinada arquitetura. De Fusco (1976) coloca ainda em paralelo a este pensamento a ideia vigente no Movimento Moderno arquitetônico, onde a noção de técnica vinha atrelada a uma noção de escolha sobre o melhor processo construtivo a ser adotado considerando valores sociais, econômicos e morais, o que caracterizava um processo cultural e sociológico, além de ser também um processo artístico.

O caráter individual da criação na arte apontado por Croce deixa de lado a categorização coletiva dos movimentos. Este conceito, contrário à lógica de equalização estética da arte dos movimentos de vanguarda apresenta-se, para De Fusco (1976), como uma lacuna deixada pelos estudos do filósofo acerca da estética moderna, que posteriormente passa a ser preenchida pelos preceitos do futurismo, dando forma à base de elaboração da ideia moderna italiana.

\section{UMA MODERNIDADE PLURAL}

O futurismo ${ }^{8}$ surgiu como uma reação ao academicismo clássico ainda praticado na Itália e que, segundo os futuristas, cada vez mais se afastava da realidade evolutiva e tecnológica das cidades. 0 pragmatismo das máquinas e o aumento do dinamismo vivido pelo ambiente moderno trouxeram o

\footnotetext{
${ }^{6}$ CROCE, 1946, p.218 apud DE FUSCO, 1976, p.183

${ }^{7}$ DE FUSCO, 1976, p.185

8 Um panorama bastante amplo sobre o futurismo pode ser encontrado no catálogo da exposição Italian Futurism 1909 1944: Reconstructing the Universe, apresentada no museu Guggenheim de Nova York, de 2014
} 
desejo de antecipação do espírito do futuro através da investida em uma reformulação da arte, do modo de vida e até mesmo na busca pela constituição de um "novo homem". ${ }^{9}$

O passo inicial para este movimento foi dado por Filippo Tommaso Marinetti (1876-1944) cujas ideias foram divulgadas na publicação de seu "Manifesto Futurista" no impresso italiano Le Figaro no início de 1909. O poeta egípcio com educação francesa mudou-se para Milão em 1894, mas continuou mantendo seus laços com a França onde adquiriu experiência editorial ao publicar seus primeiros trabalhos. Neste período, manteve também uma rede de relações com outros escritores, que mais adiante integraram o Movimento Futurista. ${ }^{10}$

Conforme Salaris (2014), para as ideias dessa nova vanguarda, a arte não deveria ser uma busca individual, mas sim uma atividade de criação coletiva em que a energia utilizada para esta criação configurasse um motor para a transformação do homem, extrapolando os limites entre a arte e a vida. A associação entre essas duas instâncias foi uma das principais contribuições do futurismo para o pensamento moderno italiano. Para tanto, ao contrário das demais vanguardas europeias que estavam ligadas a uma elite intelectual, o futurismo tomou direções capazes de atingir as massas através da ampla divulgação de suas ideias e de seus produtos de criação.

O primeiro manifesto de Marinetti, que iniciou com foco nos movimentos literários, logo atingiu as demais manifestações artísticas, incluindo a arquitetura. Também foi difundido em diversos países onde havia pesquisa por parte de seus artistas e intelectuais sobre uma nova visão para a modernidade dentro e fora da Europa.

O pintor e escultor Umberto Boccioni (1882-1916) foi um desses artistas de Milão do círculo de discussões de Marinetti que se ocupou em promover o futurismo, tanto através de sua arte, como através de novos ensaios intelectuais acerca das ideias futuristas. A partir de 1910, com a publicação conjunta do manifesto "Pintura Futurista", a dinâmica acelerada das cidades industriais passa a ser estampada tanto nas telas de Boccioni, ${ }^{11}$ como em seu manifesto de 1914, "Arquitetura futurista, manifesto", cujo conteúdo

(...) evocou a possibilidade de um "impressionismo arquitetônico", de uma arquitetura de pura necessidade, na qual "os espaços de um edifício deem o

\footnotetext{
${ }_{9}$ SALARIS, Claudia. The invention of the programmatic avant-garde. In: GREENE, Vivien (org.). Italian Futurism 1909-1944: reconstructing the universe. New York : Guggenheim Museum Publications, 2014. p.23

10 SALARIS, 2014, p.24

11 SALARIS, 2014, p.26
} 
rendimento máximo, como um motor". Anunciava, ainda, que "as necessidades dinâmicas da vida moderna darão ensejo, inevitavelmente, a uma arquitetura evolutiva", e chamava a atenção para o fato de que "os navios, os automóveis e as estações ferroviárias quanto mais subordinaram suas arquiteturas às necessidades a que deviam responder, mais ganham em expressão artística". ${ }^{12}$

As ideias de seu manifesto foram retomadas anos depois por Antonio Sant'Elia (1888-1916) em “A Arquitetura Futurista", manifesto publicado em 1914 no catálogo da exposição do grupo Nuove Tendenze, onde também apresentou a concepção de cidades futuristas através de seus desenhos. $\mathrm{O}$ manifesto que rejeitava o historicismo, carregava a noção da arquitetura como uma máquina que se valeria dos materiais modernos como o vidro, o ferro e o cimento, e das novas técnicas de construção para a composição de edifícios em que a estética ficaria a cargo das características dos materiais utilizados. Da mesma maneira, o antigo urbanismo de ruas estreitas deveria dar lugar a modernas infraestruturas, onde um perfil mais verticalizado dos edifícios revelaria as vantagens de novas tecnologias, como os elevadores por exemplo. ${ }^{13}$

O desejo de transformação empreendida pelos futuristas era tamanho a ponto de considerarem a guerra como forma de "higiene mundial" onde a morte das velhas ideias daria lugar às novas ideias, estabelecendo assim possibilidades reais de renovação total não só na arte, mas também no modo de vida. ${ }^{14}$ Este posicionamento fez com que muitos dos futuristas se lançassem à batalha na Primeira Guerra Mundial. O resultado foi a morte de alguns dos mais importantes representantes do movimento, como Boccioni e Sant'Elia.

Os efeitos desastrosos da guerra fizeram com que muitos conceitos fossem reconsiderados. Até mesmo a aproximação do fascismo ${ }^{15}$ com o ideário futurista de reestruturação da sociedade e de exaltação da máquina passaram a ser vistos com cautela. ${ }^{16}$

(...) a guerra não modifica os termos do debate cultural, mas torna mais aguda a sensibilidade para distinguir a forma da substância e mostra a necessidade de se

\footnotetext{
12 COHEN, Jean-Louis. O futuro da arquitetura desde 1889: Uma história mundial. São Paulo: Cosac Naify, 2013. p.89 citando trechos de BOCCIONI (1914)

${ }^{13}$ MEYER, Esther da Costa. Drawn into the Future: Urban Vision by Mario Chiattone and Antonio Sant'Elia. In: GREENE, Vivien (org.). Italian Futurism 1909-1944: reconstructing the universe. New York : Guggenheim Museum Publications, 2014. p.141

${ }^{14}$ ADAMSON, Walter L. Futurism and Italian Intervention in World War I. In: GREENE, Vivien (org.). Italian Futurism 19091944: reconstructing the universe. New York : Guggenheim Museum Publications, 2014. p.175

${ }^{15}$ Assim como o racionalismo, o futurismo possui um histórico de aproximação com o fascismo em virtude da postura ambígua do regime

16 O futurismo ainda resistiu por anos através de diversas vertentes dentro e fora da Itália mesmo após a Primeira Guerra.
} 
repensar radicalmente muitos daqueles termos, para que os problemas recebidos em herança adquiram significado real. Faz compreender, sobretudo, que as soluções não podem ser encontradas de uma só vez por todos na teoria - e, portanto, não pode bastar o fato de serem formuladas por um grupo restrito de pessoas -, mas devem ser verificadas na prática, envolvendo todos os interessados, e adaptadas à mutação das circunstâncias com um esforço contínuo, sem pausas. ${ }^{17}$

Após a guerra os pluralismos da busca por uma modernidade italiana seguiram alimentando novos debates. Mesmo os futuristas, que em um primeiro momento estabeleceram um movimento de ruptura com o historicismo clássico e a inserção da máquina no contexto da criação passaram, em um segundo momento, a considerar a adição de outros elementos como os de origem primitivista a partir do momento que começam a compartilhar com os racionalistas a percepção sobre a noção de autenticidade e origem existente na cultura vernacular. ${ }^{18}$

O regime fascista de Benito Mussolini (1883-1945), que em 1922 tomou definitivamente o poder, posicionou-se de forma ambígua perante às questões da cultura alternando seus conceitos de acordo com a conveniência política. Em 1923, apoiou a primeira exposição artística do pós-Primeira Guerra apresentada como Novecento, que era composta por artistas que anteriormente não teriam se alinhado à vanguarda futurista, e que neste momento buscavam contribuir para o restabelecimento da "ordem" requerida pelo regime. Entre estes artistas estava Gio Ponti (1891-1979), com quem Lina Bo Bardi trabalhou anos mais tarde.

Já em 1926, ainda vigorando o embate entre futurismo e Novecento, entrou em cena, também com o apoio de Mussolini, o racionalismo anunciado por artigos publicados pelo chamado Gruppo 7. Os jovens arquitetos que compunham o grupo traziam um estudo sobre as vanguardas europeias já consolidadas propondo uma nova "ordem" funcionalista sem que a tradição italiana fosse deixada de lado, conforme deixam claro em um trecho do primeiro dos quatro artigos publicados citado por De Fusco (1976, p.196):

\footnotetext{
"Entre nuestro pasado y nuestro presente no existen incompatibilidades. Nosotros no queremos romper con la tradición: es la tradición la que se transforma, adquiere nuevos aspectos, bajo de los cuales pocos la reconocen."
}

\footnotetext{
${ }^{17}$ BENEVOLO, Leonardo. A História da Arquitetura Moderna. Barcelona: Gustavo Gili, 2004. p.392

18 SABATINO, Michelangelo. Pride in Modesty: modernist architecture and the vernacular tradition in Italy. Toronto: University of Toronto Press, 2012. p.92
} 




FIG.1 Pintura de Umberto Boccioni

"The city rises"

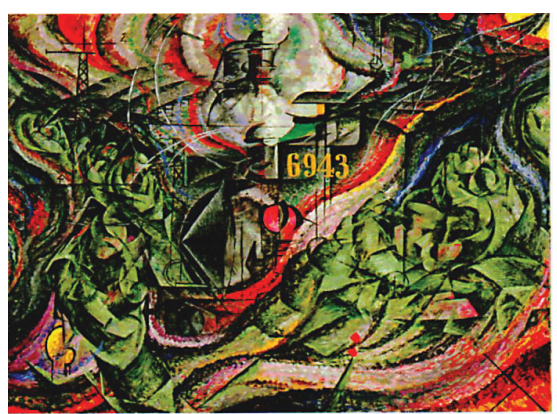

Fonte: FRAQUELLI, 2014, p.83
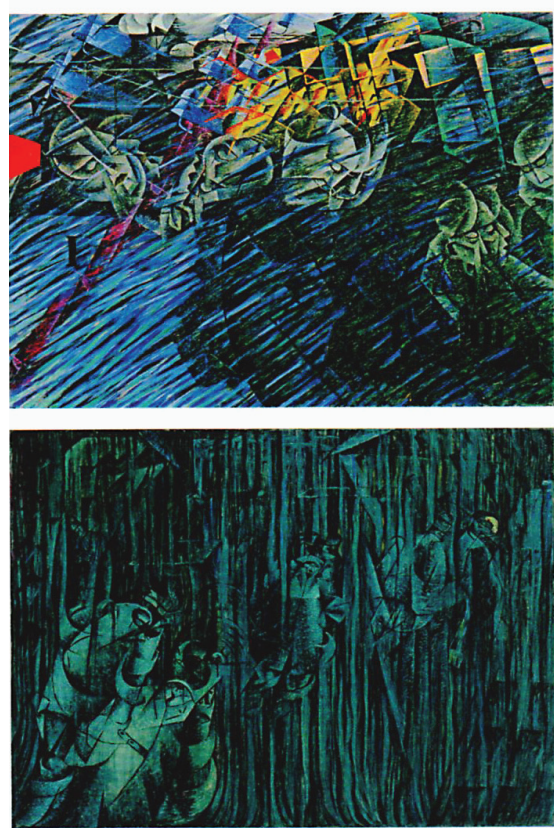

FIG.2 Série de pinturas de Umberto Boccioni

"States of mind I", "States of mind II" e "States of mind III"

Fonte: SALARIS, 2014, p.27 


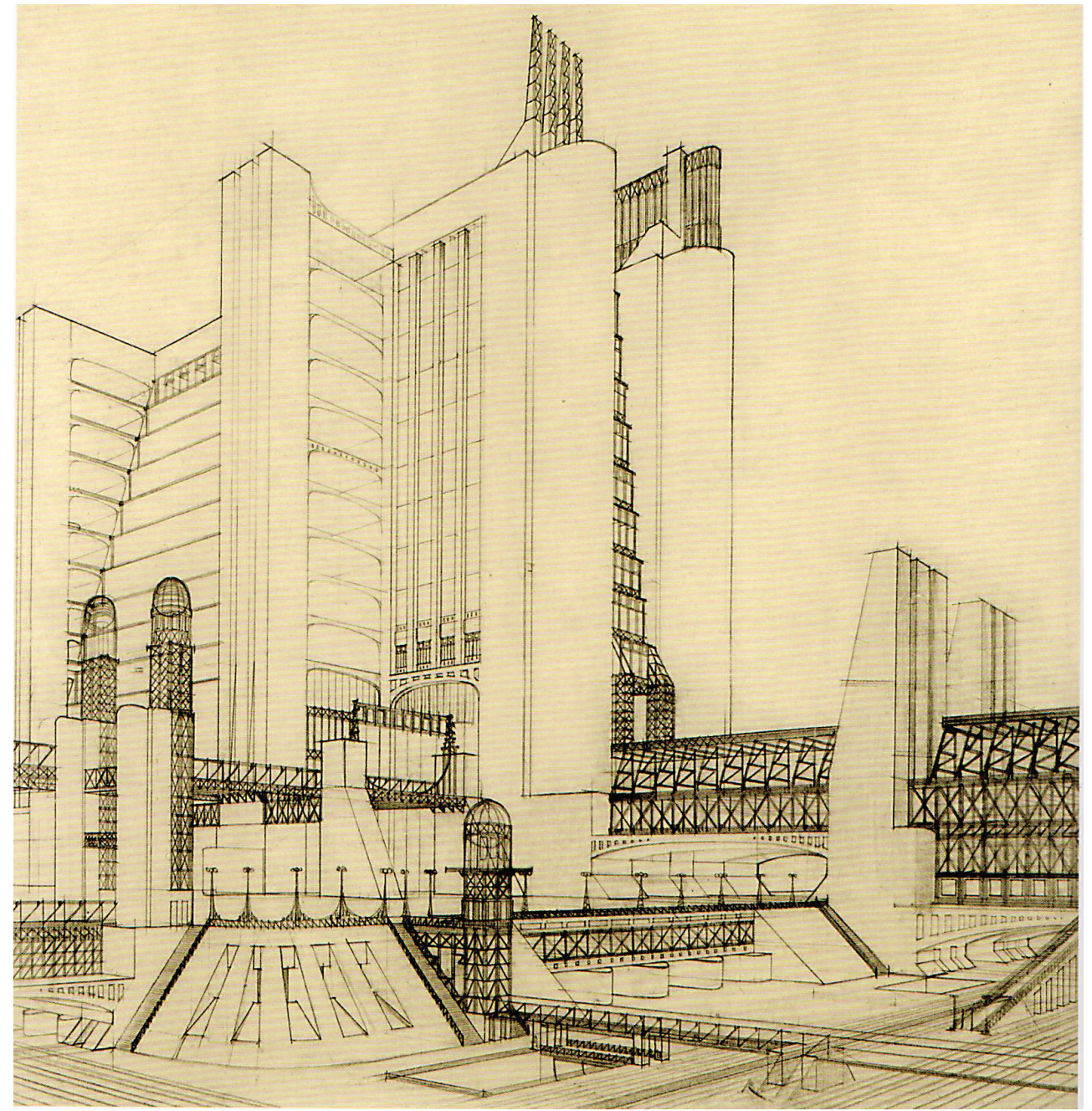

FIG.3 Ilustração de Antonio Sant'Elia "Città Nuova"

Fonte: ISGRO, 2014, p.140

\section{L'ARCHITETTURA FUTURISTA}

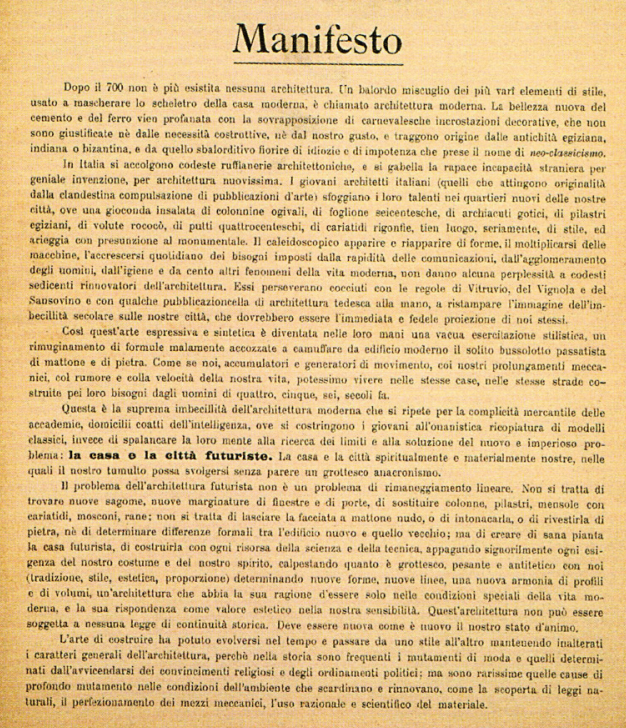

FIG.4 Manifesto "L'architettura Futurista" de Sant'Elia, 1914

Fonte: MEYER, 2014, p.143 
Entre suas proposições, por vezes contraditórias ${ }^{19}$, é importante destacar que a contribuição das ideias do Gruppo 7 para o pensamento moderno italiano acerca da continuidade histórica do ponto de vista arquitetônico, é somada ainda a outros aspectos, como a aderência à lógica, a atenção às necessidades do lugar, a importância de definição de uma tipologia construtiva, entre outras questões inerentes ao racionalismo já enunciadas inclusive por teorias anteriores. ${ }^{20}$ Deste grupo derivou ainda o Movimento Italiano per l'Architettura Racionale (MIAR) em $1926^{21}$, que acreditava em um caráter de inovação no regime fascista e no estabelecimento do racionalismo como estilo oficial.

Pietro Maria Bardi (1900-1999), em sua Galleria d'Arte di Roma, investiu na ideia do racionalismo como arquitetura do regime tomando como base a obra de Le Corbusier e promove, em 1931, a "Mostra dell'architettura racionale" que trazia um catálogo manifesto com críticas ao estilo Neoclássico. Contudo, Mussolini acaba por eleger o Neoclássico como estilo e Marcello Piacentini como o arquiteto oficial.

Neste momento também se desenvolvia o discurso antifascista proposto por Edoardo Persico (19001936) e os estudos urbanísticos e culturais por Giuseppe Pagano (1896-1945), cujos conteúdos foram fundamentais para a formação do pensamento moderno na arquitetura italiana e repercutiram diretamente nos debates vivenciados por Lina Bo Bardi.

\section{O DEBATE ATRAVÉS DAS REVISTAS CASABELLA E DOMUS}

Os editoriais configuraram uma importante plataforma de discussão dentro do contexto moderno italiano. Em 1928, foram criadas as revistas de arquitetura Casabella e Domus, que traziam em seu conteúdo debates sobre a produção arquitetônica moderna local e internacional, dedicando espaço também à pesquisa sobre as manifestações arquitetônicas vernaculares que ganhavam cada vez mais a atenção dos arquitetos como conteúdo metodológico e estético a ser compreendido e, em certa medida, aplicado na produção racionalista.

\footnotetext{
${ }^{19}$ Assim como ocorreu também com as outras formulações teóricas ainda em processo de maturação de ideias.

${ }^{20}$ DE FUSCO, 1976, p.196

${ }^{21}$ RUBINO, Silvana Barbosa. Rotas da modernidade: trajetória, campo e história na atuação de Lina Bo Bardi, 1947-1968.

Campinas, Universidade Estadual de Campinas, tese de doutorado, 2002. p.35
} 
As críticas de Edoardo Persico e Giuseppe Pagano manifestadas na revista Casabella marcaram um importante momento para a elaboração do pensamento moderno e para os arquitetos em formação nos anos 1930 e 1940, entre os quais estava Lina Bo Bardi.

Em Persico, o posicionamento socialista marxista e a declarada oposição ao fascismo contribuíram para o debate arquitetônico entendido como um produto de cultura, assim como as demais manifestações artísticas. ${ }^{22}$ Também presente nos estudos de Persico, o conceito do gosto, cuja origem esteve nos estudos do professor de artes Lionello Venturi (1885-1961), trouxe para a crítica uma abertura maior às questões culturais, históricas e sociais, elementos que normalmente não estavam incluídos de forma tão ativa no debate sobre a estética.

Para Pagano, essa atualização da crítica e a inclusão da questão do gosto serviria como pressuposto para atualização da técnica. Sua abordagem, mais sociológica que as manifestações teóricas anteriores, trouxe uma nova percepção sobre o alcance da produção arquitetônica moderna.

La arquitectura es un servicio, su punto de partida es estricta y rigurosamente utilitario... El mundo tiene necesidad de disciplina constructiva, de construcciones modestas, de buena educación... Para llegar a la verdad y sentir la arquitectura como una misión social es necesario avanzar más allá del gusto decorativo y penetrar en la substancia de las tradiciones, forzar la vanidad y considerar el problema del gusto contemporáneo como un problema de contenido. ${ }^{23}$

Através do interesse pela produção vernacular - ou "arquitetura menor" -, Pagano encontrou uma civilização construtiva, que já aplicava as premissas da poética racionalista evidenciando a "verdade" da arquitetura. Esta observação baseou-se também em uma formulação teórica de Venturi sobre o chamado "orgulho da modéstia".

O estudo da "arquitetura menor" desenvolvido pelo arquiteto ao longo dos anos 1930 repercutiu em artigos para a revista Casabella, no livro "Architettura rurale Italiana" em 1936, e na mostra homônima durante mesmo ano organizada junto com arquiteto Guarniero Werner Daniel para a VI Trienal de Milão, dividindo espaço com a mostra Architettura Moderna in Italia, de Agnoldomenico Pica. ${ }^{24}$

Outros textos de Pagano para a revista Casabella anteciparam a visão sobre quais seriam os critérios necessários para o desenvolvimento de uma nova metodologia de projeto baseada no espírito das

\footnotetext{
22 DE FUSCO, 1976, p.208

23 PAGANO, 1935, p.105 apud DE FUSCO, 1976, p.204

${ }^{24}$ COHEN, 2013, p.208-209
} 
construções vernaculares, como foi o caso do artigo "Documenti di Architettura Rurale"25, publicado em 1935 no número 95 da revista. O texto traz logo no início uma crítica à maneira como os livros de história mostravam o valor dos grandes edifícios através da classificação estética e de seus aspectos decorativos a partir de um formalismo engessado. É como se aceitação da criação do gênio como manifestação do gosto libertasse a obra de suas motivações práticas e de seu processo construtivo, fazendo com que a noção de entendimento da obra residisse apenas na questão de "como foi feita", deixando de lado a pergunta mais importante: "por que foi feita?"

Para Pagano, a preocupação central dos intelectuais ao analisar uma obra estaria relacionada ao reconhecimento da expressão comum a um determinado período, não havendo uma associação às condições sociais, econômicas e funcionais em que a arquitetura estava inserida, ainda que essas condições estivessem à frente de qualquer preocupação estética no momento de sua concepção. Usando o exemplo da leitura sobre a estrutura das construções dóricas, o arquiteto diz que apenas a intuição é capaz de apontar para o processo das necessidades técnicas que levaram até o resultado final de suas formas, pois as informações fornecidas eram baseadas apenas em uma interpretação estética e ilógica do ponto de vista funcional.

Pagano explica que a reação contra o formalismo acadêmico do século XIX opõe-se à retórica da decoração estabelecendo seu fundamento na racionalidade, na funcionalidade e na tecnologia sem abrir mão da preocupação estética. Tomando como base o fato de que a relação entre técnica e estética sempre existiu, diz ainda que as obras mais primitivas já carregavam a clareza e honestidade necessárias à construção racional, e que negar este fato ao conceber a nova arquitetura seria um erro.

(...) lo stesso desiderio di voler conoscere e dimostrare come i rapporti tra utilità, tecnica, forma ed estetica non siano invenzioni recenti ma soltanto recenti rivelazioni originate da un bisogno etico di chiarezza e di onestà, ci fanno superare ogni ritegno nel ricercare una dimostrazione storicamente documentata dei rapporti intercorsi tra l'architettura dei libri di storia e il soddisfacimento delle più semplici e meno vanitose necessità costruttive realizzate dall'uomo, con uno spirito di meraviglioso "primitivismo". ${ }^{26}$

Neste sentido, a análise da arquitetura rural - que na maioria das vezes era tratada como folclore seria capaz de demonstrar a forte ligação entre o clima, o ambiente e a tecnologia, já que historicamente a possibilidade da construção do abrigo representaria a primeira vitória do homem

\footnotetext{
25 PAGANO, Giuseppe. "Documenti di Architettura Rurale”. Casabella, Milão, no95, nov. 1935, p.18-25

26 PAGANO, 1935, p.18-19
} 
diante da necessidade de fixar-se em algum lugar para extrair seu sustento da terra. As adaptações necessárias seriam executadas pelo homem de acordo com as características de seu ambiente e, apesar da escassez de recursos, essas construções não estariam isentas de se configurarem também como realizações artísticas. Como exemplo disso, Pagano cita os casos dos iglus e das cabanas de palha. Segundo o arquiteto, esses modelos básicos foram assumindo outras formas conforme a evolução da tecnologia e da economia local, mas ainda assim preservaram a tradição e a atenção ao atendimento das necessidades em oposição à construção como mera exposição de riqueza.

A mostra "Achitettura Rurale Italiana" procurou expor, por meio de fotos de autoria de Pagano, as técnicas construtivas e a estética desta "civilização" ${ }^{27}$ a ser descoberta pelo homem moderno como fundamento para sua arquitetura.

Contemporâneo a Giuseppe Pagano, o arquiteto Gio Ponti também manifestou especial atenção à cultura popular. Entretanto, com um trabalho mais voltado à escala do desenho industrial, Ponti voltou seu olhar principalmente para a produção artesanal. Na direção da revista Domus, criada no mesmo ano de 1928, Ponti manteve um espaço editorial para discussão sobre as questões da produção do design, da arquitetura e das ténicas construtivas e materiais em desenvolvimento no período. Em seus artigos constavam desde a questão da casa moderna dentro de um contexto artístico, racionalista e em transformação, até o debate sobre relação entre a tradição e a modernidade racionalista. Esta visão que, em certa medida, se aproximava da abordagem da revista Casabella, foi retomada mais adiante também na revsita Lo Stile, criada e dirigida por Ponti.

(...) both domus and Casabella shared the objective of cultivating a new culture for the forme that would make art, architecture and decorative arts coverge into unified expressions of an organic vision of the domestic universe, which was also sensitive to make demands.

(...)

Nevertheleds, the convergences end with these generic statements of intent. In fact, once the two magazines consolidated their editorial lines and defined their interest, they radically diverged, even before Giuseppe Pagano Pogatsching took over management of Casabella in 1932, transforming it into the organ of new Italian Rationalism. ${ }^{28}$

\footnotetext{
27 Lina Bo Bardi também usa o termo "civilização" anos depois.

28 IRACE, Fulvio. Domus, a Home for Italians. In: FIELL, Peter; FIELL, Charlotte (org.). Domus, vol.I, 1928-1939. Koln: Taschen, 2006. p.12
} 
Conforme relata Lisa Ponti (1990, p. 18), a produção editorial do arquiteto teve diferentes focos ao longo do tempo que acompanharam o contexto de seus trabalhos e pesquisas, assim como acompanharam também o contexto de desenvolvimento da modernidade italiana.

In Domus, from 1928 to 1940, there is a tension of the"new,"coming out of another level of thinking. In Stile, from 1941 to 1947, the tension is between the uniqueness of arte and creativity at the service of mass production, as was required by postwar reconstruction. In Domus, from 1948 to 1979, the field was thrown open to distinctive talents from all over the world.

Contudo, o cerne de seu trabalho permanecia na esfera das possibilidades para a criação de espaços e objetos utilitários, e na manutenção do caráter informativo e didático de seus artigos, promovendo assim a coexistência entre diversas manifestações artísticas, além de embates entre diferentes posicionamentos nas páginas da Domus.

Ponti argued: "More than things, it is the spirit that has to be different and aimed at different goals in organizing the new home." This "must not be fashionable because it must never go out of style." Thus, the strategy of domus was comparable to a sort of "sentimental education" of the reader, to the "formation of an individual and collective taste", wich can be acquired only through the visual didatic of a modernity that is fully revealed in the most varied manifestations of art and contemporary culture. $^{29}$

Em acordo com o espírito da época onde estava presente a busca por um novo modo de morar, baseado no conceito moderno da "máquina de morar" de Le Corbusier, para Ponti, o espaço da casa deveria ter a qualidade conferida a um espaço funcional de muitas possibilidades, colocando em questionamento também a função de seus habitantes dentro deste ambiente. Ele acreditava que um novo modo de funcionamento do cotidiano das casas poderia repercutir em uma nova sociedade a partir de sua revisão. "Home architecture", Ponti would repeatedly write, "is not just a problem of art but also a problem of civilization." ${ }^{\prime 30}$

\footnotetext{
29 IRACE, 2006, p.13

30 IRACE, 2006, p.13
} 


\section{${ }_{18}^{18}$ O C U M E N T I D I A R C H I T E T T}

La storia dell'architettura si occupa, quasi senza eccezioni, della architettura stilistica, cioè di quella forma d'arte edilizia ritenuta meritevole di attenzione per il suo valore intenzionalmente estetico e palesemente orientato a forme decorative. Nella storia della architettura noi studiamo, generalmente, la storia del gusto architettonico attraverso le forme auliche adottate dalle costruzioni maggiori: i tem-

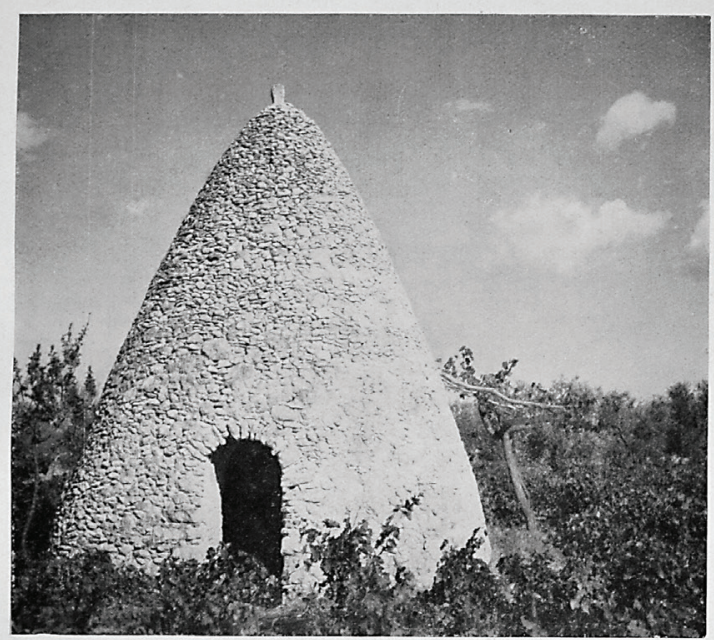

DINTORNI DI BARLETTA. TRULLO A FORMA DI PAGLIAIO, FASE SUCCESSIVA AL PAGLIAIO DI LEGNO NON SQUADRATO E COPERTO DI STOPPIA

pli, le chiese, i palazzi. Quali ragioni tecniche e quali rapporti di tradizione formale e quali influenze di carattere economico e funzionale abbiano originate queste manifestazioni non interessano per lo più nè il mondo degli studiosi nè quello degli artisti. Nell'esame dell'architettura stilistica ci interessa enormemente il «come», ma non il "perchè ». Accettiamo il fatto compiuto ed analizziamo la creazione del genio come una manifestazione del gusto, come una libera espressione dello spirito al di fuori di ogni rapporto con le ragioni pratiche del fenomeno costruttivo. Per il fatto che l'interesse critico degli studiosi di architettura rivolge la propria attenzione soltanto alla massima conclusione edilizia dei diversi periodi, non possiamo nè vogliamo collegare queste conclusioni con quelle premesse puramente utilitarie, ed inizialmente costituite da esclusivi superamenti del fatto strutturale, economico, funzionale. Sappiamo tuttavia che l'architettura dorica è una interpretazione illogica ed estetica, eseguita in pietra, di una struttura in legno inizialmente logica e comprensibile Conosciamo, più per intuizione che per esperienza, che una forma naturalmente estetica nella architettura rappresentativa e stata inizialmente suggerita dalla risoluzione di una necessità tecnica o funzionale. Ma i rapporti tra l'ultimo anello della catena e quello iniziale spesso ci sfuggono perchè crediamo morte e disperse nella preistoria

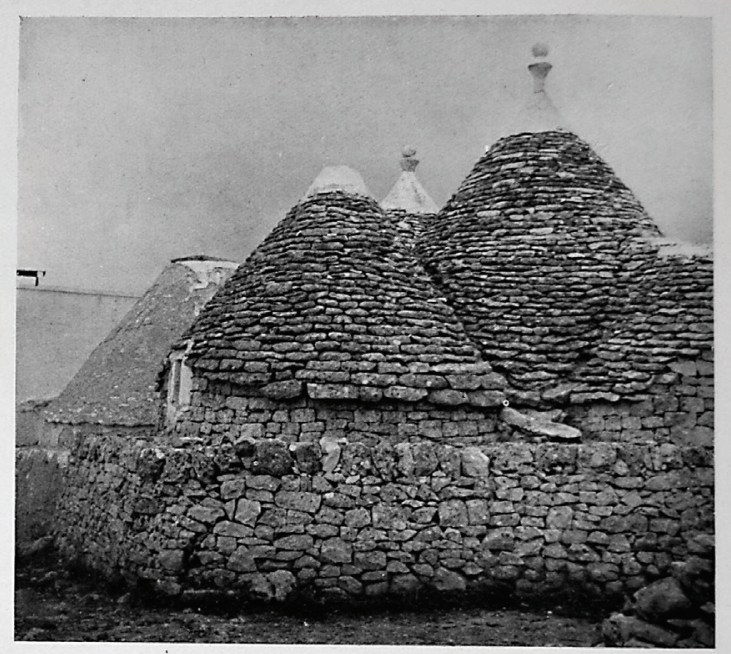

RAGGRUPPAMENTO DI TRULLI NELLA REGIONE DI BARI, DOVE LA COPERTURA DI PIETRA RICORDA IO SCHEMA DELLA COPERTURA DI PAGLIA

quelle testimonianze edilizie intermedie che han servito da lievito alalla rappresentazione aulica. Pur conoscendo che la sopravvivenza di una forma è più forte della sua stessa ragione pratica, e che una abitudine formale originata da un bisogno ben circostanziato e ripetuto, diventa abitudine estetica o gergo decorativo o inerzia tradizionale quando è cessato lo stimolo di quel bisogno, la maggioranza si rifiuta di sottoporre l'architettura stilistica a questa indagine apparentemente difficile e poco rispettosa. Ma la reazione al formalismo accademico dell'ottocento e l'indagine obbiettiva e realistica che anima il mondo moderno come una imperativa opposizione della ragione contro la rettorica dei tabù decorativi; la stessa abitudine morale dell'architetto contemporaneo di sottoporre la propria fantasia artistica alle leggi della utilità, della tecnica, dell'economia senza tuttavia rinnegare il fine estetico della sua fatica; lo stesso desiderio di voler conoscere e dimostrare come i rapporti tra utilità, tecnica, forma ed 


\section{U R A}

estetica non sieno invenzioni recenti ma soltanto recenti rivelazioni originate da un bisogno etico di chiarezza e di onestà, ci fanno superare ogni ritegno nel ricercare una dimostrazione storicamente documentata dei rapporti intercorsi tra l'architettura dei libri di storia e il soddisfacimento delle piú semplici e meno vanitose necessità costruttive realizzate dall'uomo, con uno spirito di meraviglioso «primitivismo».

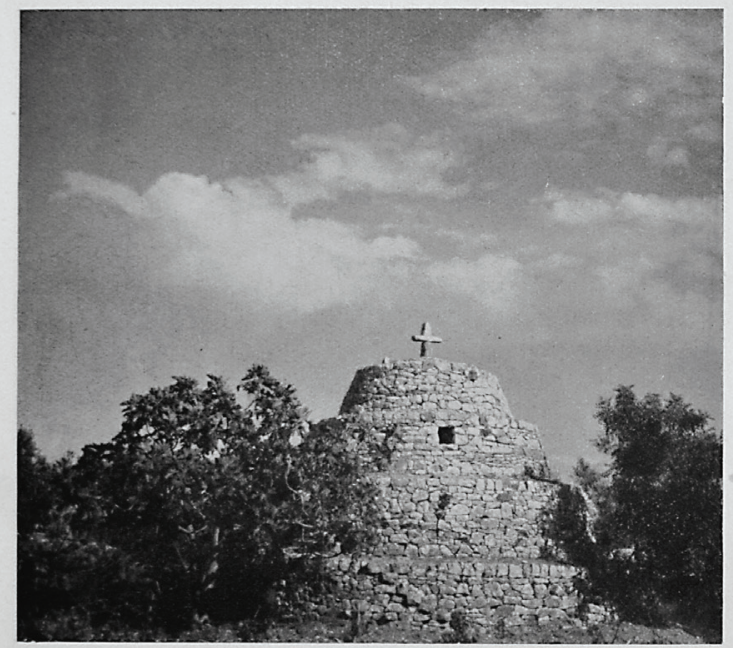

CASELLA, O TRULLO GRADINATO NELLA REGIONE DI TRANI, DOVE LA DISPOSIZIONE ESTERNA RICORDA LE PIRAMIDI A GRADONI

La difficoltà potrebbe tuttavia essere insormontabile se noi accettassimo l'idea di una architettura integralmente contemporanea, e disperassimo di trovare le testimonianze più ingenue e primitive di questi rapporti. Questo è un grave errore. Dove le condizioni climatiche, le abitudini di vita, le condizioni economiche non hanno subito sostanziali modificazioni le risultanti edilizie dell'architettura utilitaria non cambiano; dove la costruzione è interpretata come strumento di lavoro, e conseguenza della logica istintiva e primordiale dell'uomo, scaturiscono ancor oggi le stesse risultanti edilizie. Questo immenso dizionario della logica costruttiva dell'uomo, creatore di forme astratte e di fantasie plastiche spiegabili con evidenti legami col suolo, col clima, con l'economia, con la tecnica ci è aperto davanti agli occhi con l'architettura rurale. Un esame perciò dell'architettura rurale, condotto con questi criteri, può essere non soltanto utile ma necessario per comprendere quei rapporti tra causa ed effetto che lo studio della sola architettura stilistica ci hanno fatto dimenticare. L'architettura rurale rappresenta la prima e immediata vittoria dell'uomo che trae dalla terra il proprio sostentamento. Vittoria dettata da una necessità, ma satura di evoluzioni artistiche. Se l'ape fa la sua cella sempre uguale, dobbiamo ricordare che l'ape si serve sempre dello stesso materiale per costruirla e che vive soltanto in determinate condizioni di clima. L'uomo no. Esso deve sottoporre il proprio istinto alle possibilità offerte dall'ambiente. L'istinto del riparo, analogo di forma, ma diverso di sostanza, si manifesta nell'igloo eschimese o nella capanna di paglia o nel trullo, fino ad assumere apparenze sempre più evolute a seconda delle possibilità tecniche e delle condizioni economiche derivate dalla generosità del suolo. Sta però il fatto che è esistito ed esiste tuttora tutto un mondo edilizio per cui la casa non è un gioco estetico ma una necessità, non è uno sfoggio di ricchezza ma il risultato di uno sforzo realizzato col minimo disperdimento di energia. E la catena di questi graduali passaggi, col variare delle colture agricole (tipica per esempio quella del granoturco) o col variare delle condizioni economiche e tecniche è andata frantumandosi. I primi anelli della catena possono sopravvivere in un pagliaio che serve ai contadini del Lazio soltanto durante le ore diurne per il riposo dalla mietitura; una fase intermedia tra il trullo in pietra della $\mathrm{Pu}-$ glia, e la capanna di legno e paglia dei pastori può ancora sussistere in una collina della Liguria. Comunque può essere tentata la ricostruzione logica di questa catena. E l'analisi di questo grande serbatoio di energie edilizie, che è sempre sussistito come un sottofondo astilistico, può riserbarci la gioia di scoprire motivi di onestà, di chiarezza, di logica, di salute edilizia là dove l'ottocento vedeva solo arcadia e folclore. E' come fare una cura di cibi semplici per chi s'è guastato con la pasticceria delle cariatidi, e constatare quanta distanza ci sia tra le frasi fatte e la realtà. I tetti aguzzi, per esempio, si dicevano nordici. Ma se analizziamo i documenti senza pregiudizi dobbiamo constatare che anche nel meridione, quando i tetti son coperti di paglia, son molto inclinati. Non solo. Ma a Martina Franca abbiamo molte case con tetti a due falde molto inclinate, non certo per una influenza di Norimberga ma evidentemente per la resistenza locale a prediligere la caratteristica inclinazione del trullo, ricordandola anche là dove essa è illogica.

Con questi criteri e con un procedimento di esame uniforme, sarà presentata alla prossima Triennale una rassegna dell'architettura rurale italiana. La cordiale collaborazione dell'architetto Werner Daniel, che all'argomento si è dedicato con vivissimo senso critico iniziando da tempo uno studio sulla casa rurale del Trentino e del Bergamasco, mi ha fornita la traccia per tentare una indagine in tutta l'Italia. E le poche documentazioni che qui presento possono dare una idea, benchè incompleta, del materiale da noi raccolto.

GIUSEPPE PAGANO

\section{FIG.5-6 "Documenti di Arquitettura Rurale", Giuseppe Pagano Fonte: revista Casabella, no95, 1935, p.18-19}



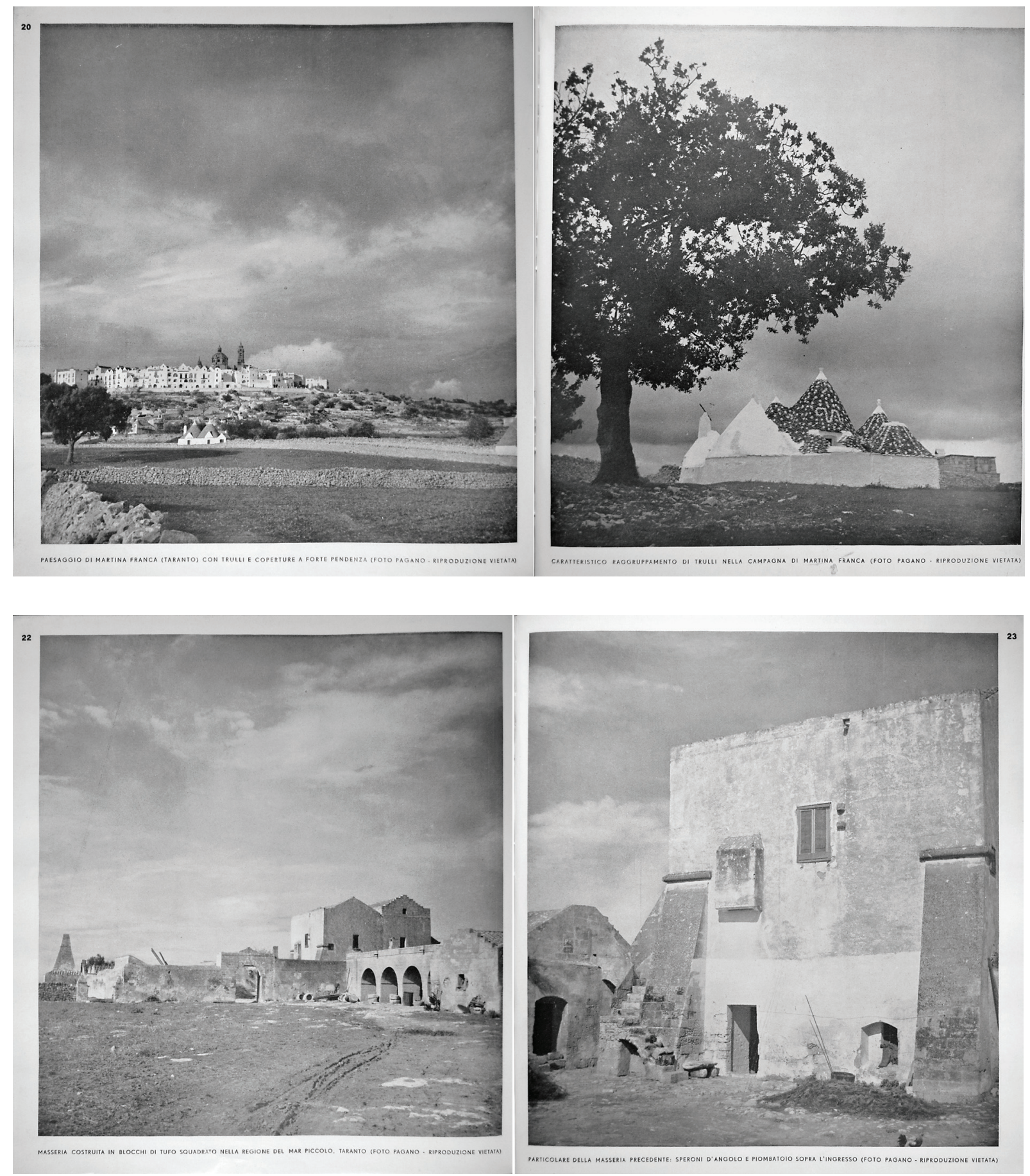

FIG.7-12 "Documenti di Arquitettura Rurale", Giuseppe Pagano Fonte: revista Casabella, no95, 1935, p.20-25 

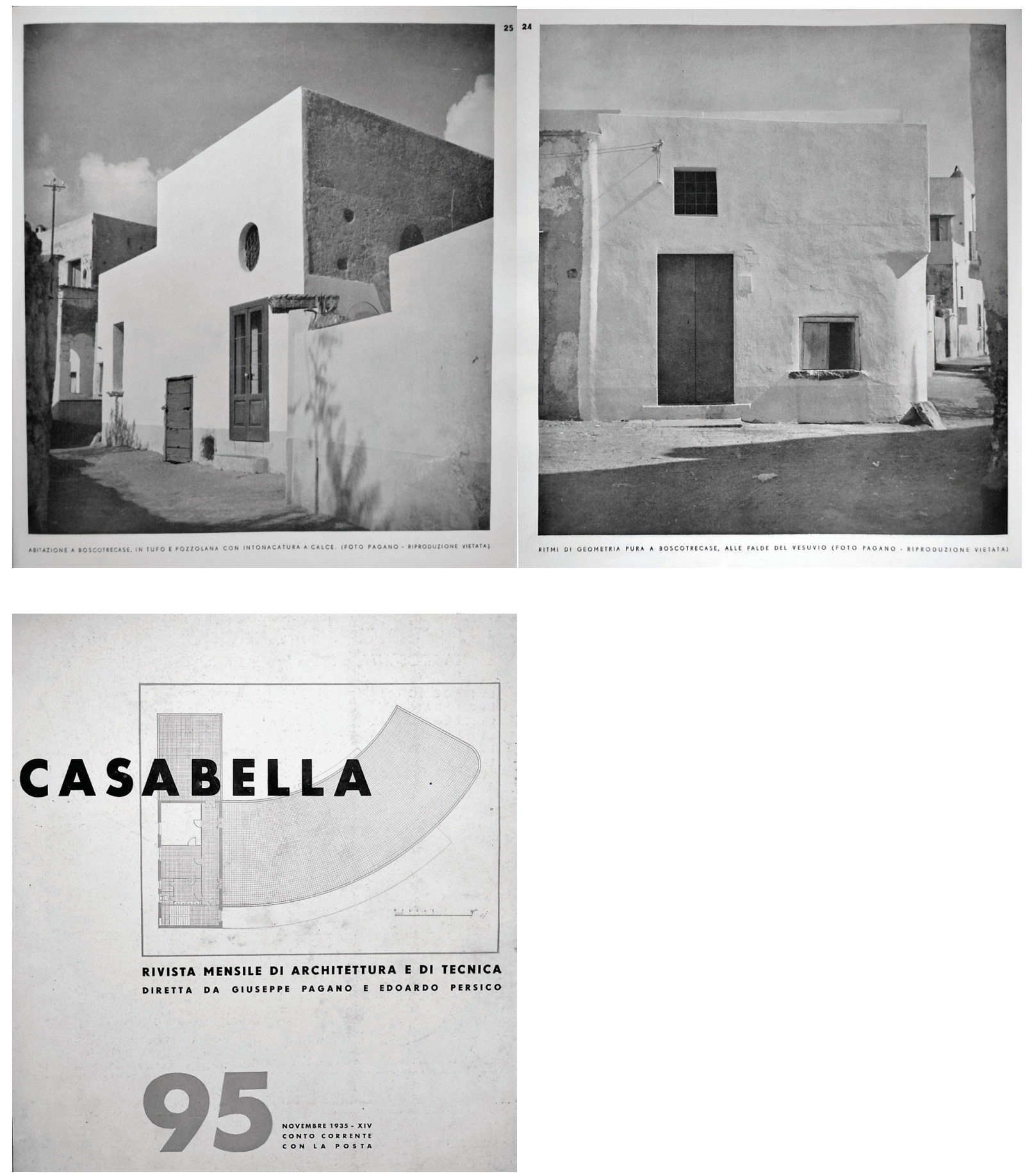

FIG.13 Capa da revista Casabella no 95 Fonte: revista Casabella, no95, 1935 


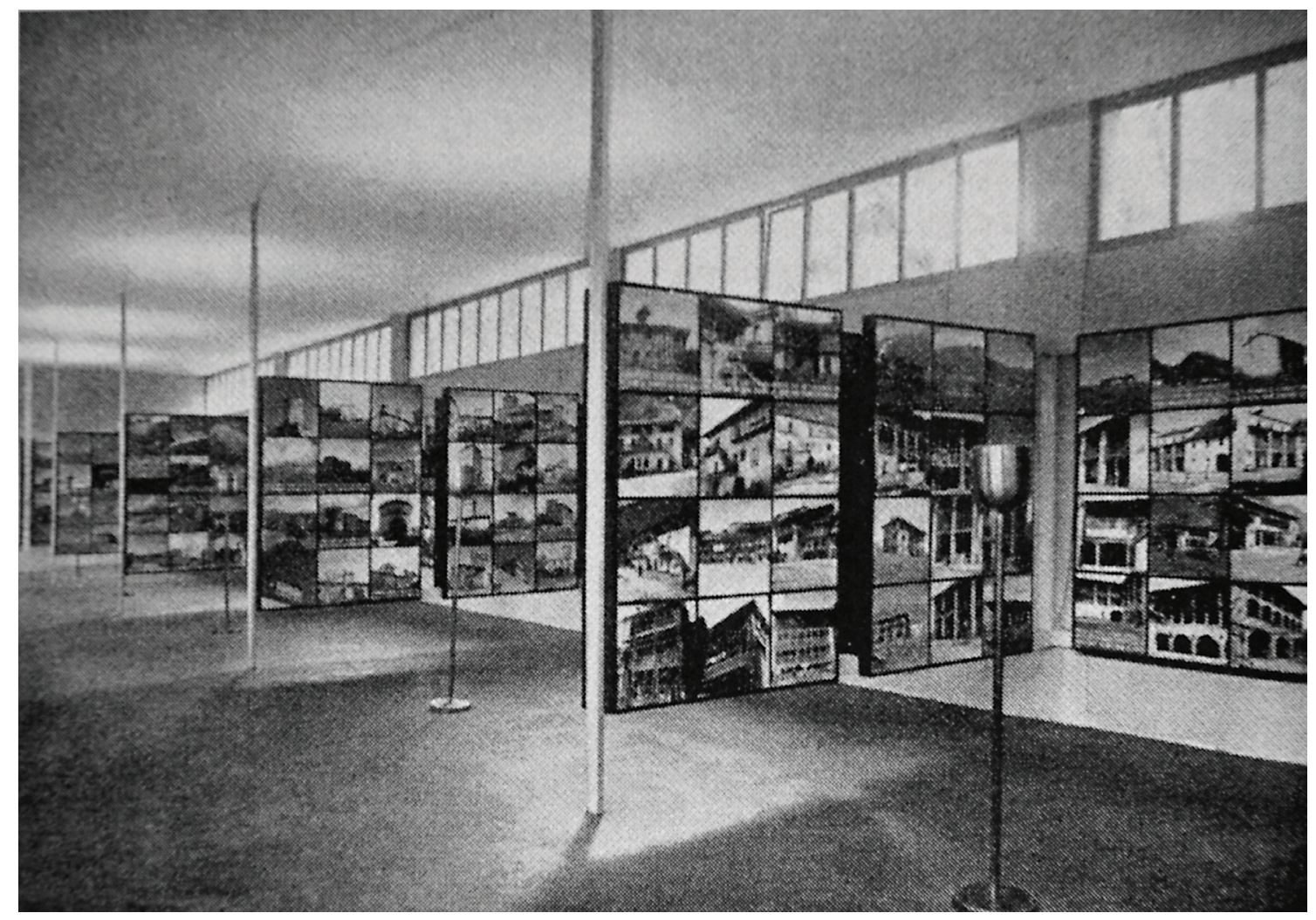

FIG.14 Mostra "Achitettura Rurale Italiana" na IV Trienal de Milão, 1936 Fonte: SABATINHO, 2012, p.132

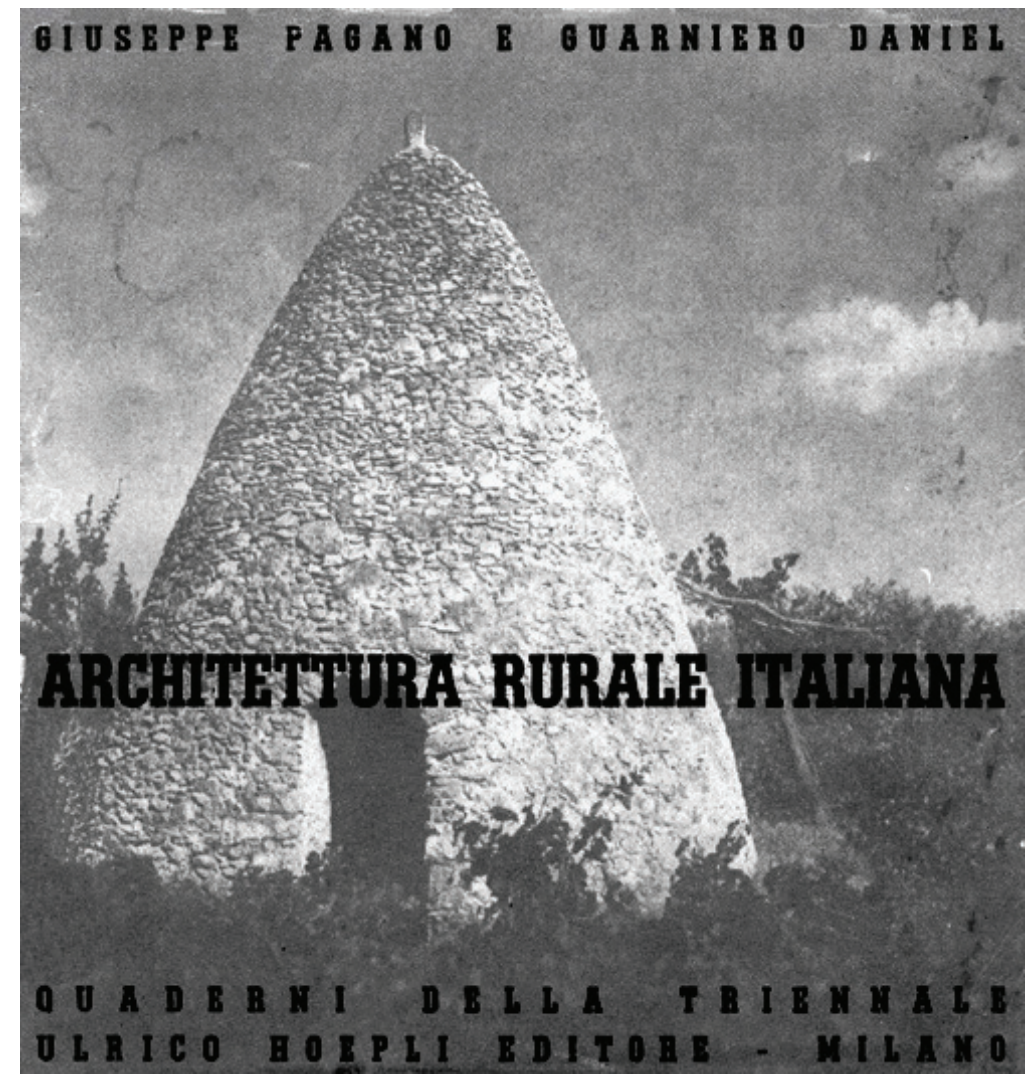

FIG.15 Capa do catálogo da mostra "Archittetura Rurale Italiana" BONOMETTO, 2005 

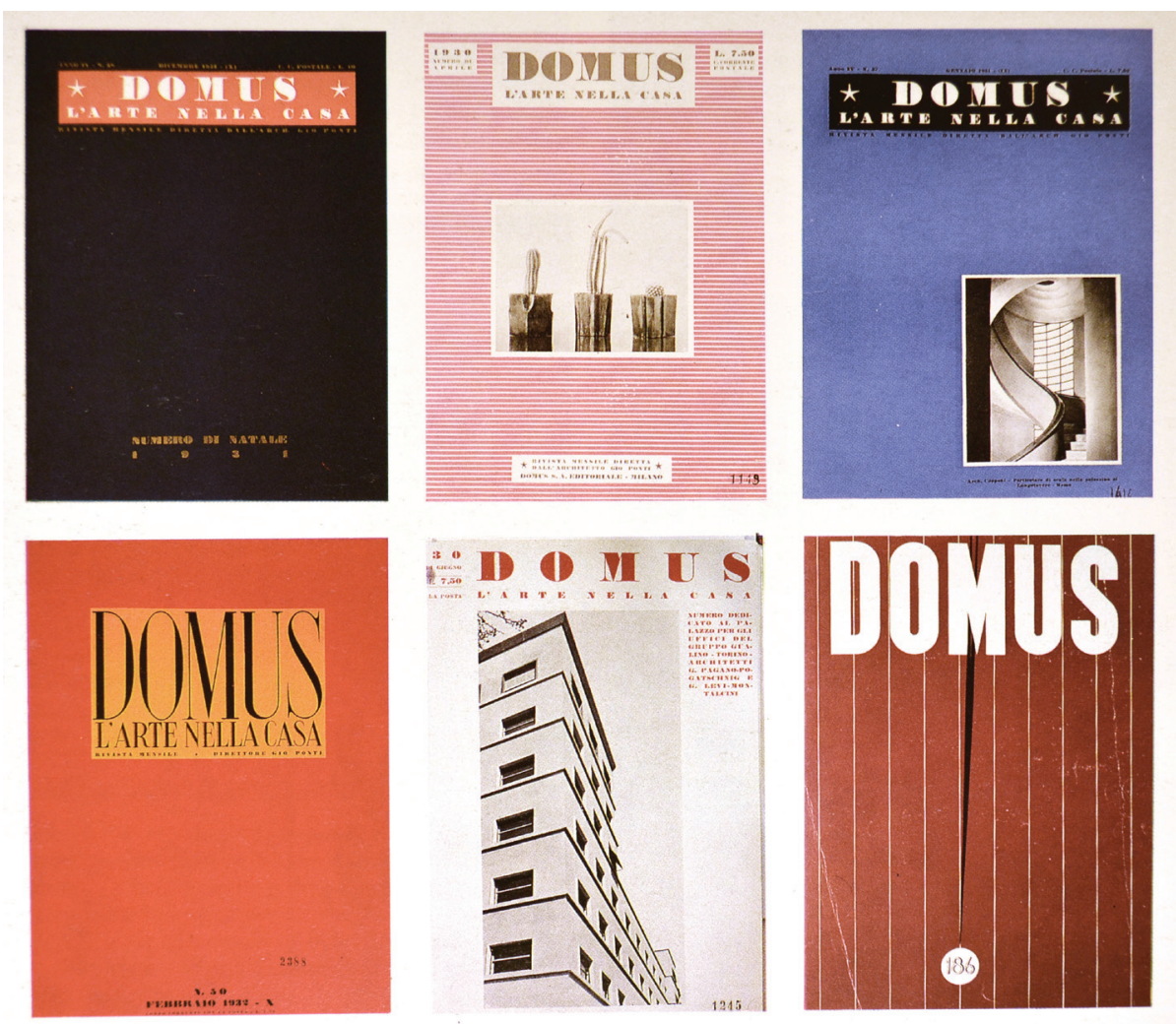

FIG.16 Capas da revista Domus

Fonte: PONTI, 1990
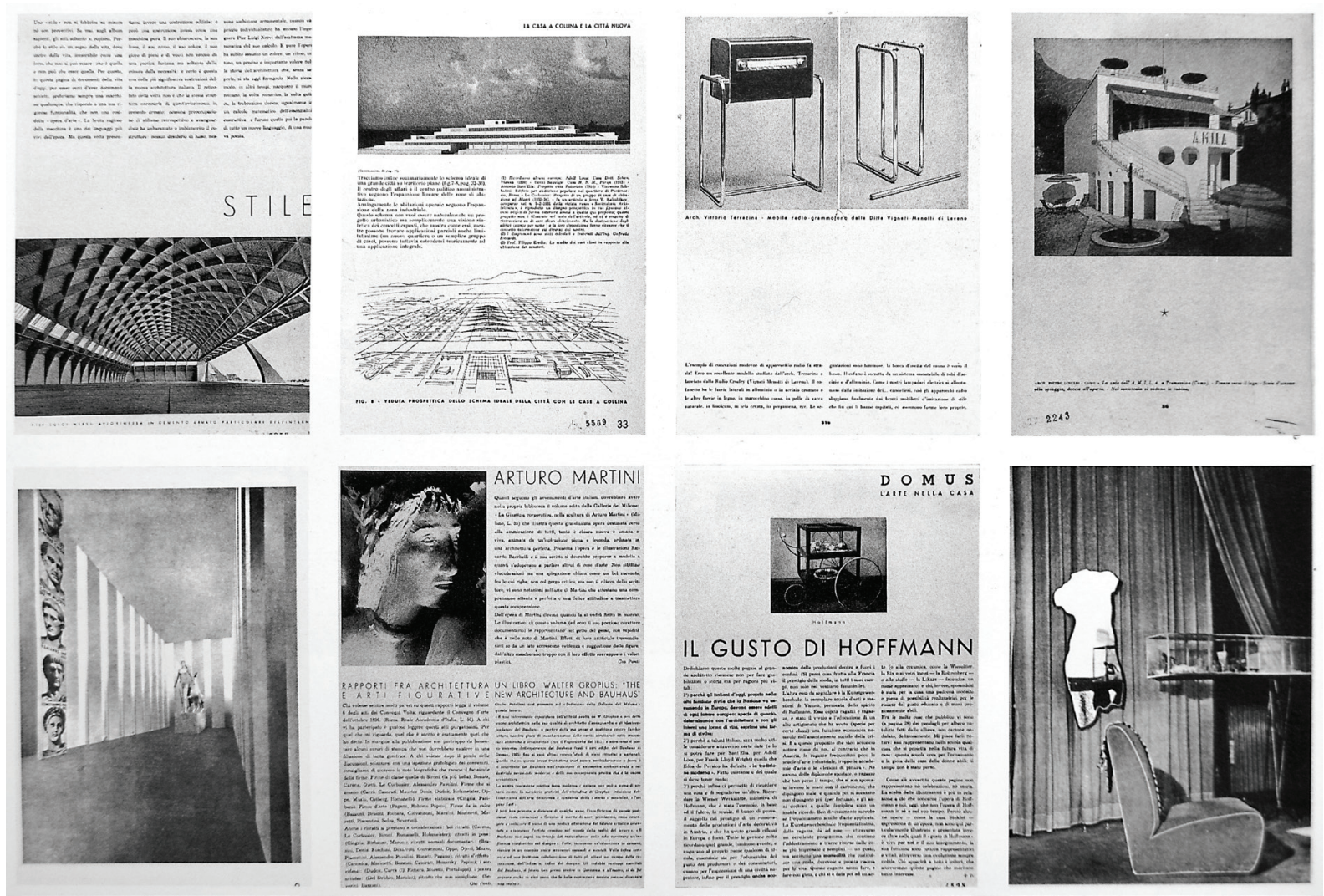

FIG.17 Páginas internas da revista Domus Fonte: PONTI, 1990 


\subsection{INTERLOCUÇÕES}

É neste ambiente de múltiplos pensamentos possíveis sobre a constituição de uma arquitetura nacional italiana que Lina Bo Bardi nasce em Roma em 1914, ano da publicação do manifesto de Sant'Elia, e forma-se architetto na Scuola Superiore di Architettura di Roma entre os anos de 1934 e 1939.

O primeiro contato de Lina com o debate sobre a arquitetura tradicional veio através do conceito pedagógico estabelecido por Gustavo Giovannoni (1873-1947) e Marcello Piacentini (1881-1960) para a escola de Roma, no qual a arquitetura tradicional e os conjuntos arquitetônicos tradicionais deveriam ser trabalhados pela valorização dos monumentos.

Neste período Lina assistiu ao embate entre a elaboração do moderno por diversas vertentes e a manutenção da ordem clássica escolhida por Mussolini como representativa do regime fascista. Presenciou na construção da Cittá Universitaria de Roma a coexistência dessas posturas através dos projetos de Piacentini para o plano geral e para a reitoria, e dos projetos modernos de Ponti e Pagano para os institutos de matemática e física entre os anos de 1932 e $1940 .^{31}$

Como estudante de arquitetura manteve contato com os editoriais em circulação, como as revistas Domus e Casabella, tomando conhecimento sobre o debate acerca da arquitetura moderna, o tema da "arquitetura menor", as pesquisas sobre o artesanato e a produção do design italiano.

${ }^{31}$ COHEN, 2013, p.217 


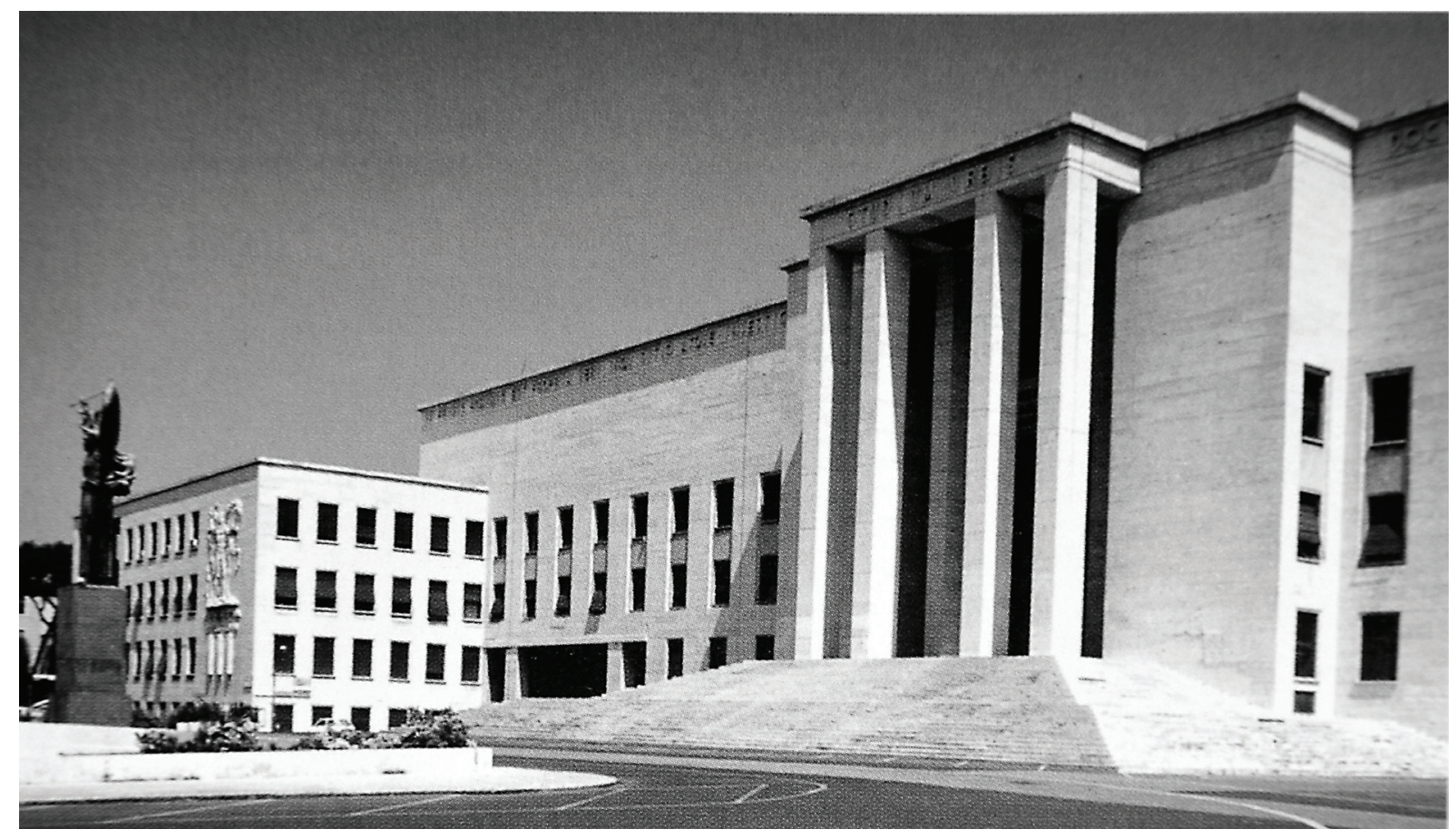

FIG.18 Reitoria da Cittá Universitaria di Roma, projeto de Marcello Piacentini Fonte: COHEN, 2013, p.274

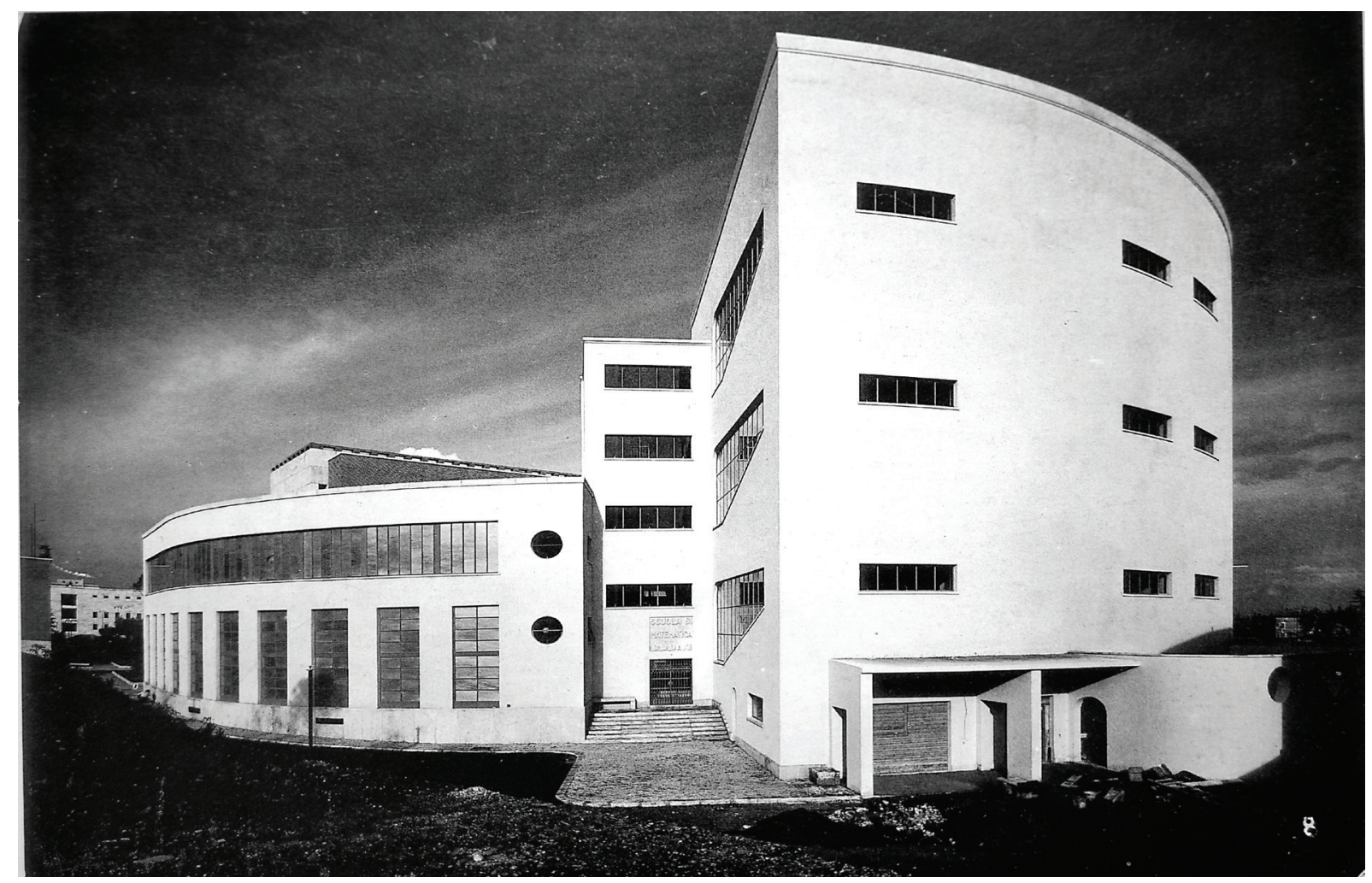

FIG.19 Instituto de Matemática da Cittá Universitaria di Roma, projeto de Gio Ponti Fonte: PONTI, 1990, p.67 
De posse deste panorama sobre as formulações da modernidade nacional, e assistindo de perto aos resultados da Primeira Guerra e o início da Segunda Guerra, Lina pôde ainda escolher fugir "das antigas ruínas recuperadas pelos fascistas" ${ }^{\prime 2} \mathrm{em}$ Roma e ir para a Milão dos futuristas e do debate racionalista em curso.

\title{
A PARTICIPAÇÃO NOS EDITORIAIS
}

Ao mudar-se para Milão, Lina começou sua atividade profissional ao lado do amigo Carlo Pagani, com quem tinha um estúdio de pequenas reformas e museografia, além de participarem juntos de editoriais ao longo dos anos (como Domus, Quaderni di Domus, Lo Stile, A - Cultura Della Vita) ${ }^{33}$. Conforme Campello $(2009$, p.4) o interesse de Lina pela arquitetura anônima manifestou-se de forma mais evidente a partir de 1941 em seus textos junto a Pagani para as revistas italianas.

\begin{abstract}
Seus primeiros trabalhos jornalísticos sobre o tema são publicados inicialmente na revista Grazia, quando ela e Carlo Pagani são responsáveis por uma seção semanal, dedicada à casa. Em um dos artigos que assinam, a atenção dos Autores se volta para a "arquitetura menor" das cidades italianas. Fazem pequenas sugestões para ocupação de espaços característicos de algumas regiões do País: loggette do Lazio, da Campania e da Calabria; terrazze que olham o mar da Bordighera; janelas da Toscana; casinhas napolitanas de volume puro e de branco calcinado.

O enfoque na tradição italiana é retomado em outro artigo - Tende e cabine- na revista Lo Stile, ainda no mesmo ano. Lina Bo e Carlo Pagani projetam abrigos desmontáveis para praia, concebidos como fruto da observação da paisagem natural e da paisagem construída de três províncias da costa mediterrânea: Liguria, Lacio e Sicilia. Pergolados, varandas, janelas e cores, são os elementos resgatados como tradicionais. $^{34}$
\end{abstract}

\footnotetext{
32 BARDI, Lina Bo. Curriculum Literário. In: FERRAZ, Marcelo (Coord.), Instituto Lina Bo e P.M. Bardi. Lina Bo Bardi. São Paulo: Empresa das Artes, 1993. p.9

33 Para maior aprofundamento sobre a participação de Lina Bo Bardi em editoriais, ver:

GRINOVER, Marina Mange. Uma ideia de arquitetura: escritos de Lina Bo Bardi. São Paulo, FAUUSP, Dissertação de Mestrado, 2010

RUBINO, Silvana; GRINOVER, Marina (Org). Lina por escrito: textos escolhidos de Lina Bo Bardi. São Paulo: Cosac Nayfi, 2009

${ }^{34}$ Campello se refere aos artigos:

BARDI, Lina Bo; PAGANI, Carlo. "Nelle vacanze d'estate semplicità e tradizione nelle vostre case". Grazia, 1941, p.31-3

BARDI, Lina Bo; PAGANI, Carlo. "Tende e cabine”. Lo Stile, no7, jun.1941, p.40-1.
} 
A participação de Lina na Domus data de 1940 a 1946, com artigos sobre o papel da arquitetura italiana em um contexto de guerra e pós-guerra, tendo inclusive a oportunidade de viajar pelo país em 1945 para registrar para a revista os estragos do bombardeio. Nestes artigos a arquiteta trabalhou seus principais campos de interesse: arquitetura americana, pré-fabricação, arquitetura orgânica, Bauhaus, moradia popular, desenho industrial, arte popular e artesanato ${ }^{35}$. Além disso, também seguiu com o desenvolvimento de uma das principais temáticas colocadas por Gio Ponti na revista Domus, destacando a importância da sistematização funcional dos ambientes internos da casa como forma de incorporar a modernidade à vida cotidiana.

No número 198, de 1944, o artigo "Sistemazione degli interni"36 inicia o texto com a seguinte indagação: "As afinidades das formas velhas como velho modo de vida estão perdidas. Como devem ser os interiores e a mobília da casa para que a adesão entre forma nova e vida se manifeste e seja coerente?" A resposta, ou as respostas, seguem com exemplos de como poderia ocorrer a interação entre arquitetura e mobiliário dentro de um ambiente moderno. Lina destaca a construção de estrutura independente como uma importante contribuição para a utilização de móveis que possuíssem flexibilidade de uso dentro de um ambiente também configurado de forma flexível. Contudo, a praticidade do ambiente não deveria significar frieza, e como podemos observar na legenda de uma das imagens que acompanham o texto, "a perfeição técnica levou a novos tipos de acabamento e materiais. Isso não significa que as casas devam assumir o aspecto de hospitais. Alguma intensidade de cor, riqueza ou simplicidade é desejável, que se pode obter também com a correta disposição dos móveis, das cores, tecidos e superfícies." ${ }^{37}$

Neste ano de 1944, Lina assumiu a direção da Domus junto a Pagani, com quem continuou a escrever textos sobre a "arquitetura menor". Em 1945 a dupla cria o encarte Quaderni Di Domus, com o intuito de dar espaço a assuntos mais aprofundados acerca do morar e de aspectos técnicos dos projetos. Este encarte continha sempre um texto teórico e um projeto detalhado pertinentes a um tema escolhido.

Ainda como parte do grupo Editoriale Domus, a revista Lo Stile (1941-1947), com direção de Gio Ponti, era considerada uma alternativa às revistas Domus e Casabella. ${ }^{38} \mathrm{~A}$ palavra estilo caracterizava-se

\footnotetext{
${ }^{35}$ GRINOVER, Marina Mange. Uma ideia de arquitetura: escritos de Lina Bo Bardi. São Paulo, FAUUSP, Dissertação de Mestrado, 2010. p.85-86

${ }^{36}$ BARDI, Lina Bo. Disposição dos ambientes internos. In: RUBINO, Silvana; GRINOVER, Marina (Org). Lina por escrito: textos escolhidos de Lina Bo Bardi. São Paulo: Cosac Nayfi, 2009. p.56

37 RUBINO;GRINOVER, 2009, p.58

${ }^{38}$ ANELI, Renato. Ponderações sobre os relatos da trajetória de Lina Bo Bardi na Itália. In: Revista Pós. São Paulo: FAUUSP, 2010, no27. p.91
} 
neste contexto como a normatização da arquitetura, e na Itália podia tomar significado tanto pelo "estilo moderno" quanto pelo "estilo clássico". Como o grupo em que Gio Ponti fazia parte propunha a comunhão destes estilos, a revista pretendia então abranger esta ambiguidade e estimular o debate sobre o "estilo moderno italiano". Somado a isso, "Gio Ponti pretendia trazer o caráter histórico da arte para o cotidiano, o que ficou claro não apenas nas seções da revista: arquitetura, urbanismo, artes plásticas, música; mas também nas matérias cujo objetivo era a 'aplicação', no cotidiano da casa, das novas modalidades formais e técnicas." 39

A partir do início dos bombardeios, a revista Lo Stile passou a incluir os debates sobre a reconstrução e o planejamento das cidades e das casas. Em 1942, o editorial contou com a colaboração de Pietro Maria Bardi através de artigos sobre arquitetura popular e sobre as oportunidades de reconstrução com o fim da guerra.

Assumindo essa abordagem os textos de Lina para a Lo Stile, entre os anos de 1941 a 1943, incluíam temas como a habitação coletiva e popular, a valorização do vernáculo e novas técnicas construtivas, destacando a pré-fabricação como alternativa para a reconstrução. A arquiteta também aproveitava as páginas do editorial para publicar seus trabalhos de arquitetura de interiores. ${ }^{40}$

A coluna La Casa, publicada a partir de agosto de 1941, oferece, para um público menos sofisticado, sugestões de decoração na linha desenvolvida sob orientação de Gio Ponti na revista Lo Stile. Em meio a generalidades da decoração, a coluna apresenta, de maneira didática, exemplos que valorizam a simplificação diante do rebuscamento, o melhor aproveitamento dos espaços internos, a reciclagem de móveis velhos, preparando seus leitores para se adaptarem às crescentes dificuldades dos tempos de guerra. ${ }^{41}$

Da mesma maneira, em sua participação na revista Grazia, trazia na coluna Casa, junto a Pagani, o debate sobre os ambientes residenciais em tempos de guerra, estendendo a discussão para a ocupação racional dos espaços da cidade.

Em conselhos e exemplos de decoração, planejamento dos espaços, escolha de materiais e mobílias Lina Bo vai ensinando as leitoras como organizar a casa dentro de valores da simplicidade, racionalização, eficiência, poesia. Com suas descrições detalhadas e desenhos, o leitor vai captando uma mensagem para incorporar em sua

\footnotetext{
39 GRINOVER, 2010,p.108

40 GRINOVER, 2010,p.111

${ }^{41}$ ANELLI,2010,p.93
} 
vida doméstica todo um universo de objetos e materiais novos que o mercado disponibilizava, sem no entanto exagerar, seja na composição, seja no consumo.

(...)

Falar da vida urbana durante a guerra era falar da vida que acontecia dentro de casa. Lina Bo, harmonizada com seus colegas, trabalhava divulgando uma nova cultura integrada com os homens e as possibilidades tecnológicas da indústria da construção. ${ }^{42}$

Terminada a guerra, como resultado do "Primeiro Convênio Nacional para a Reconstrução Edilícia", encontro realizado para o debate sobre a reconstrução da Itália, Lina cria junto a Bruno Zevi e Carlo Pagani a revista $A$. Este editorial tinha como objetivo discutir aspectos da reconstrução urbana que passassem também pela reconstrução da casa por meio da revisão de valores morais e culturais. A participação de Lina na revista esteve presente em artigos e em seu trabalho como editora responsável pelo projeto gráfico. Sob o pseudônimo de Allalo ${ }^{43}$, os artigos sobre design de interiores e cultura feminina presentes na revista também são atribuídos à arquiteta. ${ }^{44}$

A revista $A$ era curta como um folhetim e continha textos densos e fotos da destruição da guerra. Propunha uma visão ainda mais ampla e profunda sobre o modo de vida moderno, "extrapolava os limites, entrava em temas como planejamento familiar, mecanização do lar e buscava, seguindo a orientação de Zevi, ser um periódico politizado naqueles anos do imediato pós-guerra (...), era uma letra de recomeço: (h)abitação, ansiedade, amor, (h)abilidade, acordo, audácia, aviso, aspereza, absurdo, associação." ${ }^{45}$ O subtítulo Cultura Della Vita foi incorporado a partir do número 7, mas a revista resistiu apenas até o número 12.

\footnotetext{
42 GRINOVER, 2010, p.117

${ }^{43}$ Os pseudônimos eram usados como forma de proteção contra retaliações por parte do regime. Esse artifício também é utilizado anos mais tarde na revista Habitat na figura de Alencastro.

44 GRINOVER, 2010, p.

45 RUBINO;GRINOVER, 2009, p.29
} 


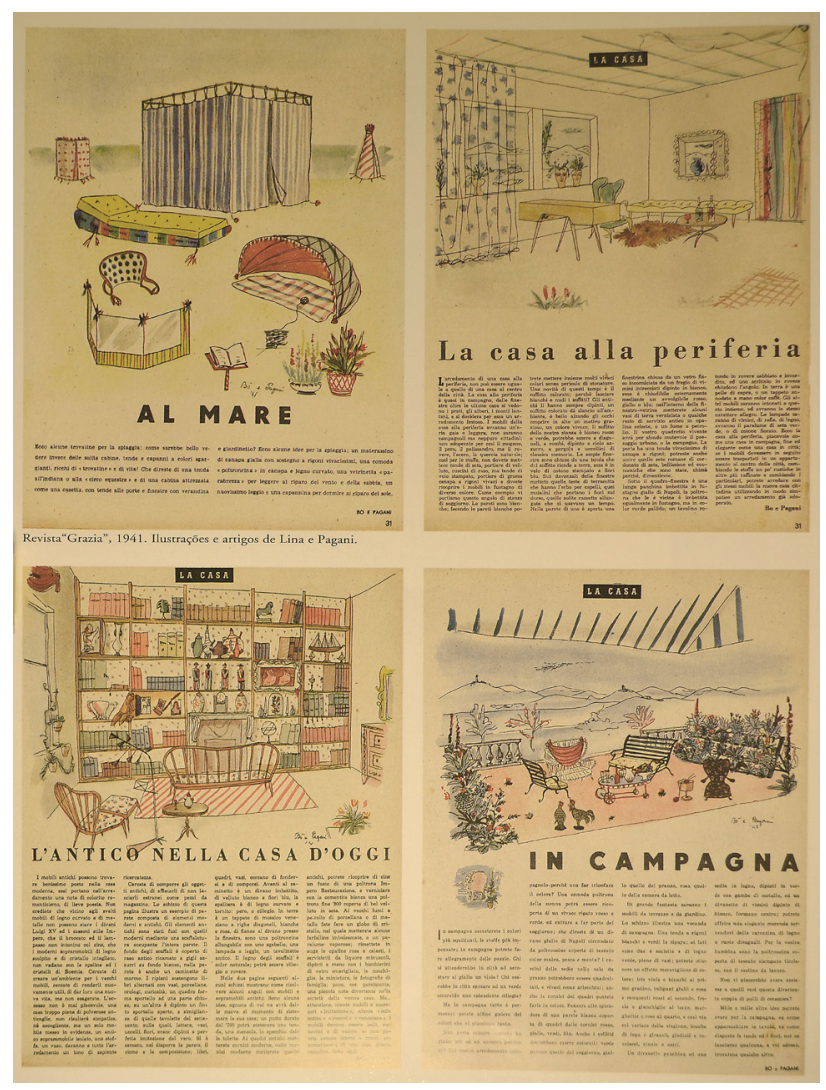

FIG.20 Artigos escritos e ilustrados por Lina e Pagani para a revista Grazia, 1941 Fonte: FERRAZ, 1993, p.28

FIG.22-23 Revista $A$ - Cultura della vita $\mathrm{n} \div 2$ Fonte: FERRAZ, 1993, p.30

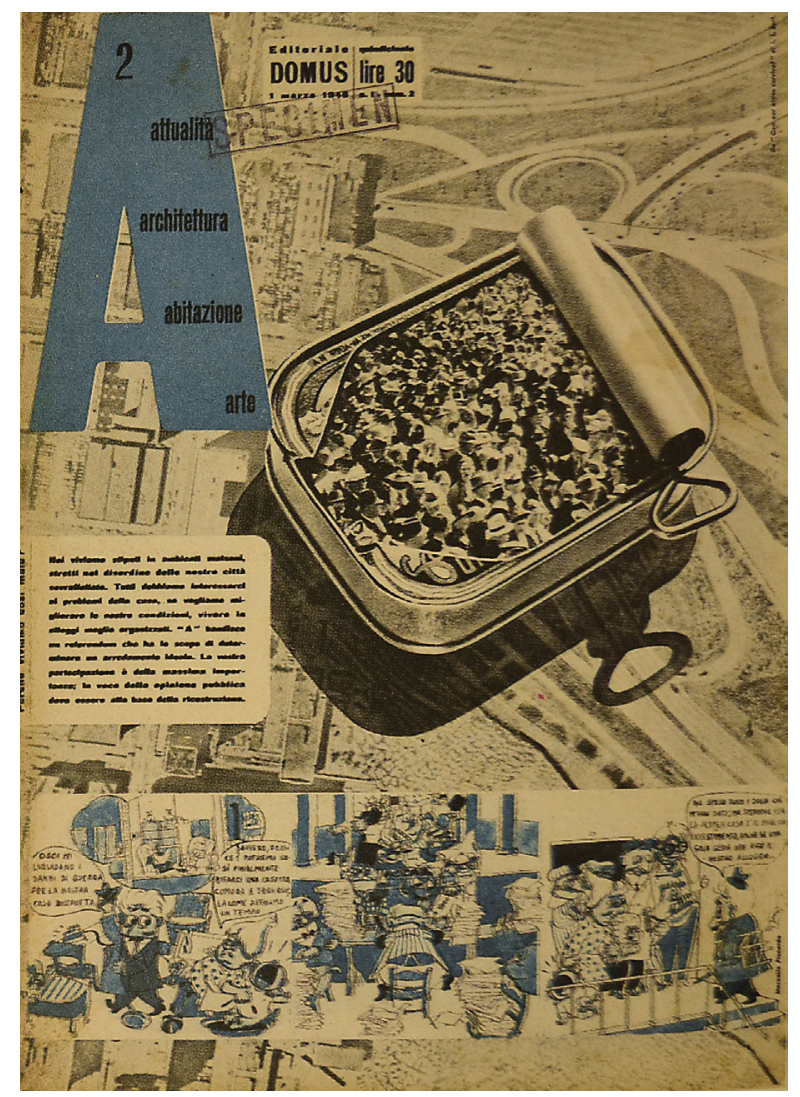




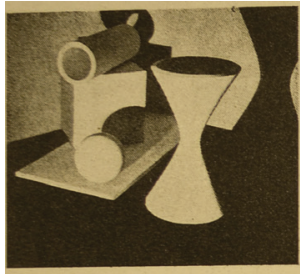

Alla ricerea di una architettura vivente

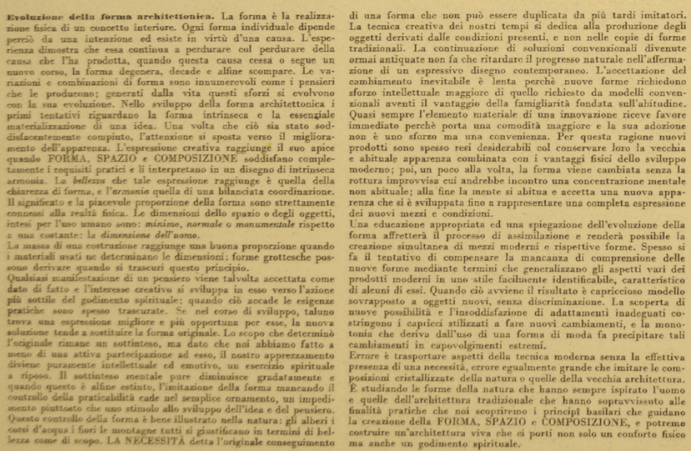

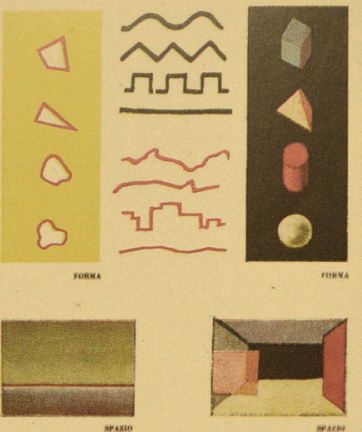

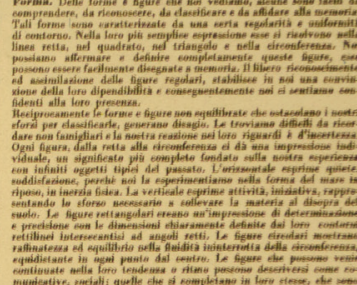

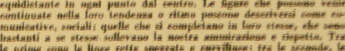

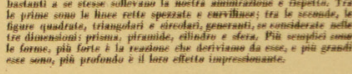

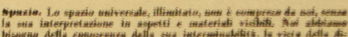

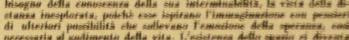

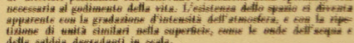

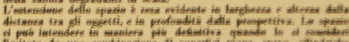
$\therefore= \pm=-2=0$ $\therefore=-1=-2=3=$

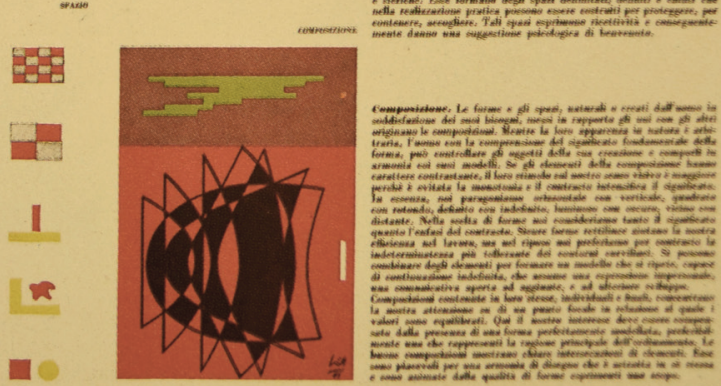

FIG.21 Páginas da revista Domus digirida por Lina e Pagani, 1943

Fonte: FERRAZ, 1993, p.29

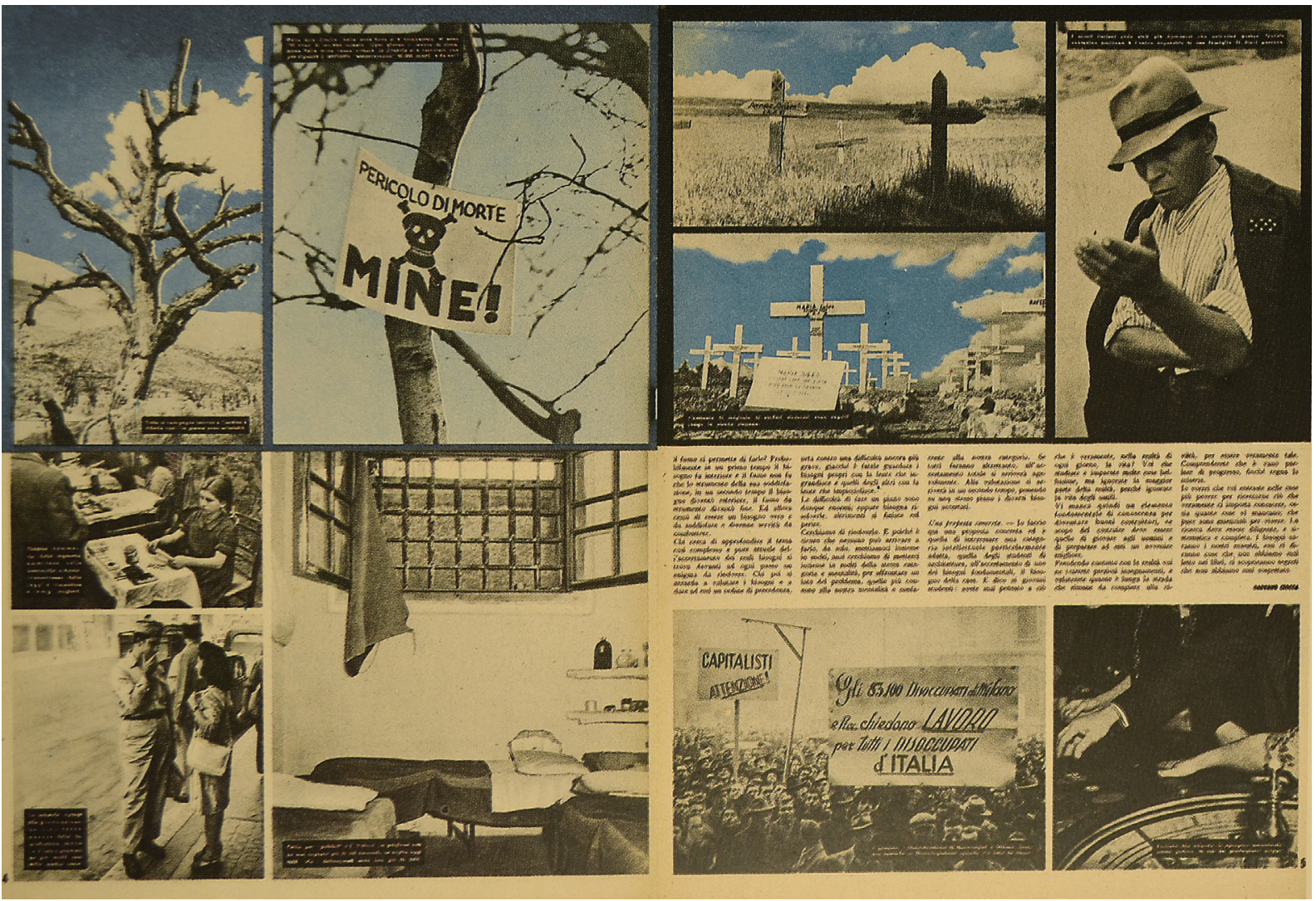




\section{O TRABALHO COM GIO PONTI}

Após formar-se como architetto, Lina trabalhou com Gio Ponti em diferentes tipos de projetos assimilando, além da experiência na prática do design, a ideia da possibilidade de um design nacional baseado na produção artesanal local estudada por ele.

Ao percorrer diversas disciplinas, escalas de trabalho e valores sociais, e tomando como referência os estudos da Bauhaus de Gropius, Gio Ponti desenvolveu uma metodologia de produção de objetos que combinava as pesquisas formais de vanguarda, as tradições artesanais e a demanda da indústria. Seus estudos, ideias e projetos por muitos anos foram colocadas ao lado de trabalhos de outros artistas na revista Domus.

The arts, that word that is used in the plural, were Ponti's obsession: the greater and lesser arts that Italy, like few other countries in the world, knew how to make converge in a natural way. They were the centerpiece of the magazine that he had always wanted to make. The focus was more on the home than on the architecture the home entered through what seemed to be its 'back door': furniture - precisely at a time when everyone was chattering pompously about reconstruction architecture. Ponti examined furniture in a surgical way, exploring its viscera by juxtaposing pictures of its components that suggested to readers and designers alike what could be done, both expressively and technically. ${ }^{46}$

Ponti foi um artista de formação clássica, e teve sua perspectiva sobre a modernidade reformulada a partir dos debates com Edoardo Persico e Giusepe Pagano, quando começou a buscar os valores de uma simplicidade racionalista, fazendo resultar em um design que contemplava a lógica da industrialização e a qualidade na quantidade. Por isso é considerado como o arquiteto que melhor representa a formação do desenho industrial italiano. ${ }^{47}$ Para Lina, mais do que isso, Gio Ponti era o líder do movimento pela valorização do artesanato italiano. ${ }^{48}$

O design para G. Ponti era entendido como um caminho para a expressão artística moderna, e seu desenho artístico uma peculiar maneira de expressar os conteúdos técnicos descrevendo-os e comunicando-os. Ponti foi atento às questões técnicorepresentativas do desenho e esta chave colocou seu trabalho num patamar

\footnotetext{
${ }^{46}$ DE GIORGI, Manolo. Vicissitudes of the 1940s. In: FIELL, Peter; FIELL, Charlotte (org.). Domus, vol.I, 1928-1939. Koln:

Taschen, 2006. p.11

${ }^{47}$ GRINOVER, 2010, p.78

48 BARDI, Lina Bo. Curriculum Literário. In: FERRAZ, Marcelo (Coord.), Instituto Lina Bo e P.M. Bardi. Lina Bo Bardi. São Paulo: Empresa das Artes, 1993. p.9
} 
experimental significativo, tanto para o desenho gráfico quanto para o desenho técnico industrial. Derivam deste trabalho sua compreensão dos materiais e suas capacidades técnico-construtivas, as pesquisas com manufatura e as possibilidades de transformação industrial foram importantes para a criação formal. Sua pesquisa deu especial atenção a uma revisão da aplicação de materiais 'tradicionais' da indústria da construção como o concreto, o vidro, o mármore, o alumínio e o ferro, a argamassa e os novos, como o plástico. ${ }^{49}$

A experiência de Gio Ponti, tão peculiar sobre a produção do espaço cotidiano através da experimentação de formas, cores, materiais e utilidades agiu claramente como uma forte influência para a formação do pensamento e para o desenvolvimento dos projetos de Lina Bo Bardi. Da mesma maneira, agiu sobre a formulação da ideia de um possível design nacional baseado na produção artesanal e na cultura popular, que acabou sendo levada adiante pela arquiteta para o contexto brasileiro anos depois.

\section{A INFLUÊNCIA DA LEITURA DE GRAMSCI}

Outra grande influência para o pensamento e para as ações de Lina foram os escritos de Antonio Gramsci (1891-1937), principalmente os que dizem sobre conceitos ligados ao cultural e ao nacional. Com um trabalho bastante amplo e engajado nas questões políticas sob o ponto de vista do marxismo, o jornalista e ativista político italiano esteve vinculado aos movimentos da classe operária de Turim até ser preso em 1926. Assim como os intelectuais italianos de sua época, teve grande influência das teorias de Benedetto Croce em seus estudos. "Estrutura, superestrutura, ideologia, filosofia, hegemonia, intelectuais, história e política, objetividade e subjetividade, individual e coletivo, necessidade e liberdade, são categorias presentes nesta interlocução com o napolitano Croce, reafirmando o esforço de Gramsci em recuperar a teoria social de Marx e traduzi-la como filosofia da práxis." ${ }^{50}$

Na prisão, onde ficou até sua morte em 1937, escreveu grande parte de suas obras, publicadas anos mais tarde como os "Cadernos do Cárcere". O conceito de hegemonia elaborado por Gramsci estava relacionado à ideia de que a condição humana seria determinante para a transformação da história, portanto, a variável econômica não seria capaz de agir como responsável absoluta pela determinação

\footnotetext{
49 GRINOVER, 2010, p.79

50 SIMIONATTO, Ivete. Cadernos do cárcere. Rev. bras. Ci. Soc. São Paulo, v. 17, no 48, p. 212-215, fev. 2002. Disponível em: <http://www.scielo.br/scielo.php?script=sci_arttext\&pid=S0102-69092002000100016\&lng=en\&nrm=iso> Acesso em: 23 nov. 2015
} 
de diferentes classes sociais, existindo também fatores ideológicos e sobretudo, fatores culturais, na determinação deste sistema. A histórica manutenção de uma hegemonia consentida por determinada classe social diante de outra precisaria ser então revista através da conscientização das classes desfavorecidas. ${ }^{51}$

\begin{abstract}
Reconstrução, a palavra de ordem de uma geração que cresceu sob o fascismo e durante a guerra aproximou-se do comunismo, tinha um peso muito maior do que a mera reconstrução física do que havia sido bombardeado. O termo adquiria uma conotação política, da reconstrução social e cultural do país. É o período da publicação póstuma dos textos que Antonio Gramsci escrevera no cárcere, da emergência da cultura popular como um problema no meio intelectual italiano. ${ }^{52}$
\end{abstract}

A leitura de Gramsci, ainda na Itália, fez com que Lina carregasse suas interpretações sobre a questão da hegemonia para o caso brasileiro, onde sua crítica ao comportamento da burguesia diante das questões sociais do país se tornou ainda mais contundente. "Esse conhecimento da obra de Gramsci mais tarde se desdobraria em seus escritos sobre arte popular, sua distinção entre nacional e nacionalista, e nesse momento remetia à faculdade que todo homem tem de pensar, e também a noção de que a filosofia de uma época não é outra coisa que não a história dessa mesma época." ${ }^{\text {"53 }}$

Outra formulação de Gramsci presente na obra de Lina é a diferenciação entre o nacional e o nacionalista, noção também ligada à questão da hegemonia. "Quando Gramsci propôs a expressão nacional-popular pretendia interpretar o nacional e o popular distintamente da hegemonia burguesa ou fascista. O nacional significava a possibilidade de resgatar o passado histórico cultural italiano como patrimônio das classes populares: seria o passado resgatado pela consciência e pelos sentimentos populares." ${ }^{25}$

Anos depois, Lina resgata este conceito ao falar de sua experiência vivida na Bahia onde enxergou grandes possibilidades da realização de uma arte nacional consciente de seu papel na formação de uma produção industrial, mas que foi interrompida pelas circunstâncias políticas dos anos 1960, do qual trataremos mais adiante.

E aqui queremos ressaltar a distinção, feita por Antonio Gramsci, entre NACIONAL e NACIONALISTA. Nacional é diferente de Nacionalista. Goethe era nacional alemão, Stendhal, nacional francês, mas ne um nem outro foram nacionalistas. Nacionais são

\footnotetext{
51 STRINATI, Domenic. Cultura popular. Uma introdução. São Paulo: Editora Hedra, 2000. p.160-162

52 RUBINO, 2002, p. 59

53 RUBINO, GRINOVER, p.37

54 MACHADO, Vanessa R. Dos "parangolés" ao "eat me: a gula ou a luxúria?". São Carlos, EESC-USP, tese de doutorado, 2014
} 
os valores reais de um País, ao passo que nacionalistas são as atitudes políticas que visam impôr (sic) certas particularidades de um país com todos os meios, às vezes com a violência. Nacionalistas foram Hitler e Mussolini, a última guerra mundial foi provocada pelos ufanismos nacionalistas. ${ }^{55}$

\section{O ENCONTRO COM PIETRO MARIA BARDI}

Se há uma interlocução importante sob o ponto de vista prático para as realizações de Lina posteriormente no Brasil, esta se deu de forma direta através do relacionamento com Pietro Maria Bardi. Jornalista, marchand e crítico de arte, conheceu Lina entre seus trabalhos editoriais e suas atividades na Studio d'Arte Palma.

Na Itália, alinhado ao regime fascista, procurou exercer influência sobre a definição do racionalismo como a estética oficial, mas como já mencionado, tem sua investida fracassada com a escolha de Mussolini pelo estilo neoclássico. Bardi esteve envolvido no debate sobre a formação da modernidade italiana através da revista Quadrante, além de se relacionar diretamente com os principais intelectuais da época envolvidos nessa discussão, como Pagano, Terragni e Le Corbusier.

Contudo, assim como a maioria dos intelectuais alinhados inicialmente ao regime, perde as esperanças na construção de uma modernidade racionalista após a destruição da guerra e parte para o Brasil junto com Lina Bo Bardi, com quem se casa em 1946.

\footnotetext{
55 BARDI, Lina Bo. Discurso sobre a significação da palavra artesanato. SUZUKI, M. (Coord.). Tempos de Grossura: o Design no Impasse. São Paulo: Instituto Lina Bo e P. M. Bardi, 1994. p. 17
} 


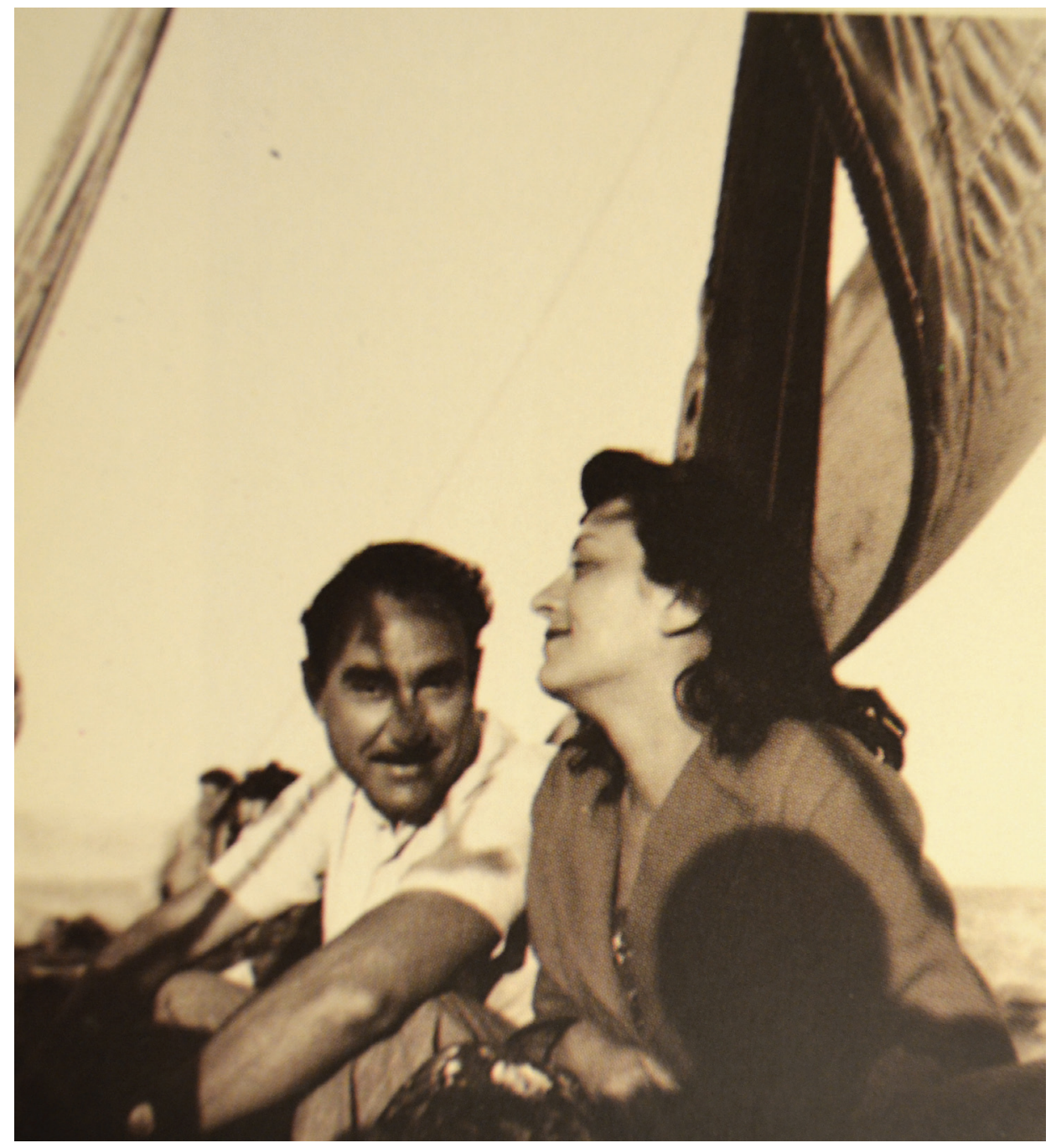

FIG.24 Lina Bo e Pietro Maria Bardi, 1946 Fonte: FERRAZ, 1993, p.37 


\subsection{OS PRINCÍPIOS DE LEITURA SOBRE A CULTURA POPULAR}

Os anos de Lina Bo Bardi na Itália no momento da formação de uma modernidade nacional pós Risorgimento foram fundamentais para a construção do pensamento ético e estético da arquiteta. Sua experiência nos editoriais e em projetos de diversas escalas em um contexto de guerras e de questionamentos ideológicos, foram motores de um engajamento político sobre as questões da arte.

A convivência e o debate com os principais intelectuais participantes do movimento moderno italiano trouxeram elementos de leitura e ação sobre a arte e a arquitetura contribuindo para a formação de um repertório que aos poucos se desenvolveria por Lina, constituindo uma atuação por seus próprios meios e interpretações. A questão da cultura popular, neste sentido, serviu como chave para o desenvolvimento metodológico desses elementos de forma definitiva nos projetos posteriores da arquiteta.

Iniciamos aqui uma investigação sobre a possível gênese destes elementos a partir do entendimento sobre o que chamamos de princípios de leitura sobre a cultura popular. Seguem a arquitetura para o homem, o cotidiano como construção da história, o saber fazer e a arquitetura menor.

\section{ARQUITETURA PARA A VIDA DO HOMEM}

As transformações sociais, econômicas, estruturais e tecnológicas da modernidade europeia fizeram com que a relação do homem com seu ambiente de vida e com seu tempo fossem repensadas. Nas artes, esta reformulação esteve vinculada a um caráter crítico que colocou em cheque antigas definições estéticas. Soma-se a isso a destruição das cidades pelas guerras, algo que intensificou ainda 
mais este questionamento, reforçando também o âmbito político dessa necessária mudança de posicionamento.

Lina Bo Bardi expôs essa condição ao relatar a destruição da casa do homem não só do ponto de vista físico e espacial como também moral, com sua crítica a uma estética excessiva adotada nas casas burguesas até aquele momento. Após o fim das guerras, a urgência da reconstrução tornou mais evidente a necessidade de que as ações assumissem de forma definitiva e como preceitos essenciais a economia, a funcionalidade e a racionalidade na arquitetura.

Foi então, enquanto as bombas demoliam sem piedade a obra e a obra do homem, que compreendemos que a casa deve ser para a "vida" do homem, deve servir, deve consolar; e não mostrar, numa exibição teatral, as vaidades inúteis do espírito humano; então, compreendemos porque as casas ruíam, e ruíam os estuques, a miseem-scéne, os cetins, os veludos, as franjas, os brasões; porque, de manhã, tudo era montinhos cinzentos desoladamente idênticos.

(...)

A guerra destruiu os mitos dos "monumentos", também na casa, os móveismonumentos não devem existir mais, (...) os móveis devem 'servir", as cadeiras para sentar, as mesas para comer, as poltronas para ler e repousar, as camas para dormir, e a casa assim não será um lar eterno e terrível, mas uma aliada do homem, ágil e serviçal, e que pode, como o homem, morrer. ${ }^{56}$

Nota-se em seu discurso a apreensão dos conceitos de Gio Ponti sobre a concepção racional dos ambientes da casa como forma de racionalização também das relações sociais e da consciência do homem sobre si mesmo diante do espaço que habita. Esta lição, Ponti, por sua vez, trouxe do entendimento sobre a "máquina de morar" de Le Corbusier e da lógica de produção proposta pela Bauhaus de Gropius.

Contudo, a ideia da casa como ambiente racional e funcional não se aplicaria apenas às construções urbanas. A investigação de Pagano sobre as habitações rurais trouxe também a importância da racionalidade na produção dessas construções ao mostrar que esta condição estaria diretamente relacionada ao atendimento das necessidades do homem vinculadas ao seu modo de vida e ao trabalho.

${ }^{56}$ BARDI, Lina Bo. Na Europa a casa do homem ruiu. In: RUBINO;GRINOVER, 2009, p.66-67 
A casa é um refúgio, um workshop seminal, uma célula viva e da civilização na luta constante e com as forças mais misteriosas e mais poderosos da natureza. A tradição desta luta constante se manifesta em todos os lares rurais, quando foram construídas pelas mãos do agricultor. A casa rural é uma ferramenta de trabalho; a ferramenta de trabalho mais importante e mais animada que a alma de um agricultor constrói. E da ferramenta de trabalho tem as características: nada é inútil, nada é tudo o supérfluo é nascido de uma necessidade. Uso sustentável dos materiais, a distribuição de volume, a adaptação às condições climáticas, o estilo de construção ingênua da região, a vontade de superar com astúcia e com paciência os problemas essenciais da habitação, a simplicidade calma e áspera com que resolver em uma necessidade essencial primitiva, mas ainda suficiente para uma fonte, um assento, um telhado de transformar a arquitetura rural de honestidade em um edifício livro, cheio de ensinamentos.

(...)

A tradição da casa rural não é, portanto, representado por certas formas, mas por sua mente funcional. ${ }^{57}$

Compreendendo a amplitude desta questão e fazendo referência aos estudos de Pagano ${ }^{58}$, Lina Bo Bardi estabeleceu os termos para uma nova visão sobre a arquitetura ligada à vida do homem, ao ambiente e a suas faculdades técnicas ao concluir que,

A pesquisa realista do mundo moderno, destruidora de toda superficialidade, de todo preconceito, de todo decorativismo, trouxe para a arquitetura a relação SOLO, CLIMA, AMBIENTE, VIDA, relação que, com maravilhoso primitivismo, vemos brotar da mais espontânea das formas da arquitetura: a arquitetura rural. (...) A arquitetura moderna trouxe à precisa relação de TÉCNICA, ESTÉTICA e FUNÇÃO aquele complexo organismo que é a casa, e estabeleceu uma estreita ligação entre esta e a terra, a vida, o trabalho do homem. ${ }^{59}$

No campo teórico italiano, a noção de "técnica interior", elaborada por Croce, trouxe valores morais importantes para a determinação das escolhas técnicas do arquiteto, tornando a visão sobre o processo de produção do espaço também composto por fatores sociológicos e culturais. A formação dessa técnica, por sua vez, estaria atrelada às experiências do artista, bem como ao ambiente no qual

\footnotetext{
57 PAGANO, Giuseppe. "Case Rurale", Casabella, no 86, fev. 1935, p. 12-13

58 Além de abordar seus conteúdos, Lina Bo Bardi faz uma referência direta ao "maravilhoso primitivismo" destacado por Pagano no artigo: PAGANO, Giuseppe. “Documenti di Architettura Rurale”. Casabella, Milão, no95, nov. 1935, p.18-25

59 BARDI, Lina Bo. Arquitetura e natureza: a casa na paisagem. In: RUBINO;GRINOVER, 2009, p.48
} 
e para o qual se estaria produzindo. Desse modo, ao trabalhar com as condições pré-determinadas como variáveis fundamentais para a criação, o artista não se afastaria das questões reais impostas por cada situação, gerando condições para a aproximação efetiva entre a teoria e a prática. Para Lina, esta arquitetura condicionada ao ambiente aproximava ainda mais a arquitetura à vida do homem.

O instinto primordial de proteção que inspirou as cabanas de palha e galhos, os abrigos em forma de cones, de cubos de blocos de pedra maciços, se encontra de novo hoje, através de uma evolução profunda, nas arquiteturas de casas que, embora adaptadas às severas leis de funcionalidade e essencialidade da arquitetura moderna, conservam sempre a "pureza" das formas espontâneas e primordiais das quais derivam: conservam ainda na pedra regular, na madeira trabalhada, aquele sentimento "puro", "natural" na qual elas estão inseridas, radicadas à terra onde nasceram, fundidas à natureza, imersas naquela paisagem. ${ }^{60}$

Esta conciliação entre arte e vida também esteve presente nas ideias futuristas como maneira de viabilizar a transformação do ser humano. Ainda que manifestada através de propostas mais radicais que as apresentadas por outras concepções de modernidade, trouxe como contribuição fundamental, nesse sentido, a negação ao tradicionalismo clássico e a valorização da concepção da arquitetura por meio da pureza das formas e das características dos materiais.

\section{O COTIDIANO COMO CONSTRUÇÃO PERMANENTE DA HISTÓRIA}

A ideia de aproximação da arquitetura à vida do homem, ao ambienete a sua volta e a seu modo de vida colocou em evidência a questão do cotidiano. A funcionalidade dos espaços da casa e seu mobiliário deveria ser favorável à eficiência das atividades a serem ali desenvolvidas. Da mesma maneira, deveria ser com os ambientes de trabalho, estudo, lazer e também na cidade. Essas atividades do cotidiano, inerentes ao desenvolvimento das tradições, seriam responsáveis pela construção da história que se montaria a cada dia somando experiências e alterando seus resultados à medida que as necessidades do homem se modificassem.

Para Croce, esse dado histórico seria fundamental para a nova criação, e as combinações entre o velho e o novo seriam a chave para uma comunicação híbrida que pudesse atingir tanto as pessoas com conceitos antigos como as pessoas com novos conceitos sobre a concepção dos espaços. Em seus

${ }^{60}$ BARDI, Lina Bo. Arquitetura e natureza: a casa na paisagem. In: RUBINO;GRINOVER, 2009, p.48 
estudos, Croce também considera que através da consciência sobre a construção da história como uma ação contínua pode-se reelaborar as atitudes do presente a partir da crítica ao passado tornando, assim, as ações atuais tão eficientes quanto precisam para atender às necessidades do presente, (...) "é de Benedetto Croce a visão de que o juízo histórico é determinado pelo presente, por um sujeito que para agir observa a situação contemporânea para a partir desta avaliar o passado."161

Com um pensamento similar sobre a questão da construção da história, o Gruppo 7 propôs uma nova ordem funcionalista que deveria ser criada sem que se deixasse a tradição de lado, ou seja, que se conservasse os métodos tradicionais de produção. E por tradição entende-se os processos tradicionais sedimentados e não a tradição clássica, combatida como uma estética estagnadora da história e componente de um historicismo retrógrado.

\section{O SABER FAZER}

O saber fazer, intrínseco à prática arquitetônica, e destacado por Croce, traz a noção de que as questões técnicas, econômicas e utilitárias seriam tão importantes para a concepção da arquitetura quanto as características do ambiente de implantação da construção. Esta conciliação entre meio ambiente, função e racionalidade faria com que o arquiteto não se desvinculasse dos problemas reais da produção das cidades.

Atenta a esta ideia, Lina Bo Bardi, em 1943, escreve na revista Lo Stile sobre um projeto de Luigi Piccinato cujo saber fazer do arquiteto foi colocado a prova em uma situação com restrições para a concepção da obra pretendida. O conjunto residencial projetado na década de 1940 para ser construído em Mazzini, um bairro de construções tradicionais de estilo floreal (ou pseudoestilo, como dizia a arquiteta), se destacaria em meio às construções vizinhas por seu caráter moderno e funcional, uma arquitetura em franco contraste com as necessidades humanas (... e) responde exatamente a necessidades reais e práticas da vida contemporânea. ${ }^{62}$

As soluções empregadas por Piccinato em meio às dificuldades para a execução da obra foram destacadas por Lina como uma atitude moderna de sua arquitetura. A primeira questão descrita estava relacionada a dificuldade de implantação do conjunto, que para respeitar os grandes recuos impostos pela regulamentação urbanística, aproximou-se muito de um jardim de grandes eucaliptos. Além disso,

\footnotetext{
${ }^{61}$ RUBINO; GRINOVER, 2009, p.37

62 BARDI, Lina Bo. A moradia nos bairros habitacionais em Roma. In: RUBINO;GRINOVER, 2009, p.42
} 
a regulamentação urbana também exigia que a construção ocupasse uma pequena parcela do terreno, de maneira que houve a necessidade de dividir o conjunto de apartamentos em dois blocos. Assim, para a criação de uma circulação comum para todo o conjunto, se "impôs a necessidade de uma construção aérea, com formas bem definidas e individualizadas, isoladas perfeitamente pelo ar. Por isso surgiram a escada completamente aberta e os patamares-passarela." 63

A outra questão encontrava-se na limitação dos materiais de construção utilizados para esta edificação, o que evidenciou a capacidade técnica e criativa do arquiteto em lidar com as condições que se encontravam disponíveis naquele momento. Piccinato,

\begin{abstract}
lutou contra graves dificuldades técnicas, resolveu problemas, empregou materiais desprezados no passado, fez, segundo suas próprias palavras, 'acrobacias', chegando à conviç̧ão de que 'o princípio básico para fazer arquitetura é procurar redescobrir e valorizar os materiais que nos são oferecidos, aceita-los, esses materiais, sem camufla-los e sem envergonhar-se deles, mas, ao contrário, exaltá-los'; e da sua construção não se pode senão escrever: alvenaria ordinária, reboco comum, estuque romano, travertino, quartzitos, madeira de castanheiro-da-europa e faia... ${ }^{64}$
\end{abstract}

A limitação de recursos para a construção foi bastante recorrente nas obras de Lina Bo Bardi anos mais tarde no Brasil. Diversos projetos em que a arquiteta esteve envolvida necessitaram de soluções habilidosas e precisas, que acabaram por favorecer a criação de formas e ambientes inusitados, carregados da verdade requerida pelas construções modernas.

Da mesma maneira, na escala do desenho industrial, a partir do trabalho com o arquiteto Gio Ponti, Lina apreendeu a noção da utilização dos materiais disponíveis e das tecnologias em desenvolvimento para a criação de objetos que integrassem os espaços do homem com base nos saberes do trabalho artesanal. O resultado desta produção, por seu caráter utilitário e estético, poderia integrar o conjunto de um design nacional.

Esta noção racional e funcional da produção do espaço e dos objetos de uso cotidiano, inerente ao espírito da modernidade, foi destacada por Pagano em suas pesquisas sobre a arquitetura rural italiana. $\mathrm{O}$ arquiteto observou nas construções do campo a racionalidade utilizada no emprego dos materiais disponíveis e a funcionalidade no resultado dessas construções capazes de suprir as necessidades de suas populações.

\footnotetext{
63 BARDI, Lina Bo. A moradia nos bairros habitacionais em Roma. In: RUBINO;GRINOVER, 2009, p.43

${ }^{64}$ BARDI, Lina Bo. A moradia nos bairros habitacionais em Roma. In RUBINO;GRINOVER, 2009, p.46
} 
Osserviamo anzitutto che le caratteristiche della principalmente da una constante e rigorosa osservanza dei principi funzionali imposti dalle abitudini edilizie del luogo (materiali più economici del posto, tradizione di lavorazione, attitudini delle maestranze locali), dalle necessità climatiche e dalle necessità tecniche imposte dal tipo di coltivazione. La architettura rurale, difatti, è quella che fin dai primordi della civiltà, è nata e si è sviluppata seguendo i più rigorosi principi funzionalisti e utilitari, progredendo nelle sue manifestazioni come una conseguenza logica scaturita da evidenti necessità pratiche. Nella storia della edilizia rurale si possono leggere ancor oggi le tappe della civiltà umana e osservare vivi e tangibili i rapporti tra i materiali impiegati, le necessità pratiche risolte, le condizioni economiche rispettate e le forme adottate. $^{65}$

O saber fazer na arquitetura vernacular estaria, então, vinculado à tradição sob um processo de transmissão de conhecimentos técnicos e estéticos que sofreram, e continuam a sofrer, transformações e adequações ao longo do tempo.

\section{A ARQUITETURA MENOR}

O campo das "artes menores" na Itália era definido pelos manuais de história da arte como o conjunto de produtos artísticos não enquadrados em classes da academia. Eram produtos utilitários, funcionais, que serviam ao cotidiano e que, em tese, não teriam uma expressão artística definida, embora preservassem uma intenção estética. Esta definição, que a princípio era recorrente no universo do desenho industrial, foi também levada à arquitetura. Neste caso a "arquitetura menor" seria aquela ligada estritamente à prática e produzida por "não-arquitetos" a partir de suas necessidades utilizando apenas os recursos que dispunham.

A formação da modernidade italiana e a busca pela gênese da arquitetura nacional incluiu a atenção à "arquitetura menor" na agenda das diversas vertentes do movimento moderno. Contudo, é através dos estudos de Giuseppe Pagano que conseguimos ter mais acesso a esta produção. Com seus artigos para a revista Casabella e com a mostra "Architettura rurale Italiana" na VI Trienal de Milão, o arquiteto divulga esta produção gerada a partir das necessidades do homem no campo por meio dos materiais disponíveis e dos conhecimentos transmitidos através de gerações, constituindo a tradição construtiva de determinado lugar.

\footnotetext{
65 PAGANO, Giuseppe. “Case Rurale”, Casabella, no 86, fev. 1935, p. 9-10
} 
No artigo "Architettura rurale in Italia"66, Pagano diz que a arquitetura rural italiana descrita por John Ruskin em meados do século XIX carregava o mesmo caráter ainda nos anos 1930. As formas simples, sem ornamentos ou adereços inúteis, continuavam a cumprir seu papel funcional e a demonstrar a dignidade da construção. A grandeza e a nobreza dessa arquitetura estaria em sua capacidade de cumprir de forma eficiente com as necessidades requeridas à vida no campo. Entretanto, Pagano atenta para o fato de que alguns elementos excessivos estariam sendo levados para o campo por meio de assistências técnicas ou mesmo de influências externas, colocando em risco a pureza dessas construções. Por outro lado, as condições econômicas e as reais necessidades do cotidiano poderiam servir como importantes barreiras para o desenvolvimento de uma estética não condizente com o contexto da vida rural.

Em seu texto, Pagano segue mostrando exemplos dessas influências, e diz ainda que podemos considerar como um fato que ocorre tanto da arquitetura acadêmica para a arquitetura rural quanto o oposto, ainda que a influência da arquitetura rural sobre a arquitetura acadêmica ocorresse de forma quase inconsciente, já que os elementos da arquitetura rural não seriam admitidos na academia. No artigo "Case Rurale", também da revista Casabella, publicado alguns meses antes, Pagano diz sobre esta situação:

Nelle scuole di architettura un professore si vergognerebbe di occuparsi di concimaie o di affidare un tema di laurea sul progetto di una fattoria. Eppure quanto bene potrebbe fare la sensibilità di un architetto rigorosamente funzionale, messa a profitto di un tema artistico cosi vivo, cosi pieno di responsabilità e cosi affine ai postulati morali della architettura moderna. Le illustrazioni di alcuni progetti allestiti dall'architetto Gino Levi - Montalcini nel 1931, danno la dimostrazione di questa sensibilità rurale degli architetti moderni e fano pensare come potrebbe essere utile ai geometri se essi potessero essere educati alla semplicità in una scuola dove insegnassero architetti vivi, che non si vergognano di progettare una casa per contadini. $^{67}$

Assim como todos os outros estudantes de arquitetura que foram privados desse conhecimento profundo da tradição popular durante sua formação na academia, Lina Bo Bardi manteve contato com este debate de olhar atento à "arquitetura menor" e suas possibilidades para a modernidade através das discussões nas revistas, do contato com os estudos de Pagano e da experiência com Gio Ponti.

\footnotetext{
66 PAGANO, Giuseppe. "Architettura rurale in Italia", Casabella, no 96, dez. 1935, p. 16-23

67 PAGANO, Giuseppe. "Case Rurale", Casabella, no 86, fev. 1935, p. 14
} 
Como já destacado nos elementos de leitura sobre a cultura popular descritos anteriormente, esse olhar para a cultura vernacular não se voltava exatamente às formas e materiais, mas tinha como foco principal os métodos utilizados e a ética aplicada, sem que a estética fosse deixada de lado. Tais atributos, totalmente compatíveis com as premissas modernas traziam a simplicidade e a criatividade como características essenciais da produção popular que poderiam ser tomadas como princípio também pelos arquitetos. 



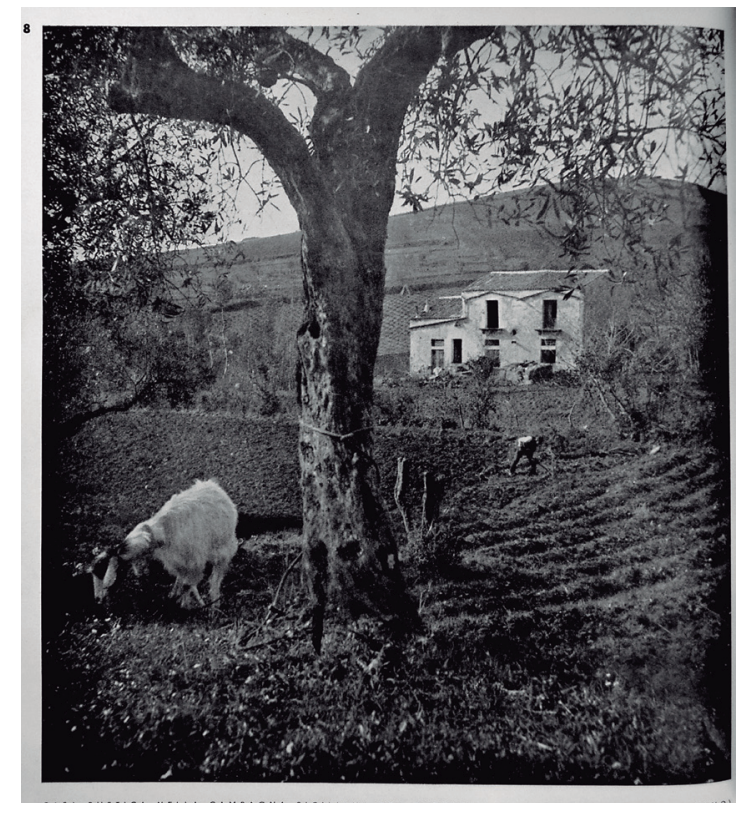

FIG.25-26 "Case Rurale", Giuseppe Pagano Fonte: revista Casabella, no86, 1935, p.8-9

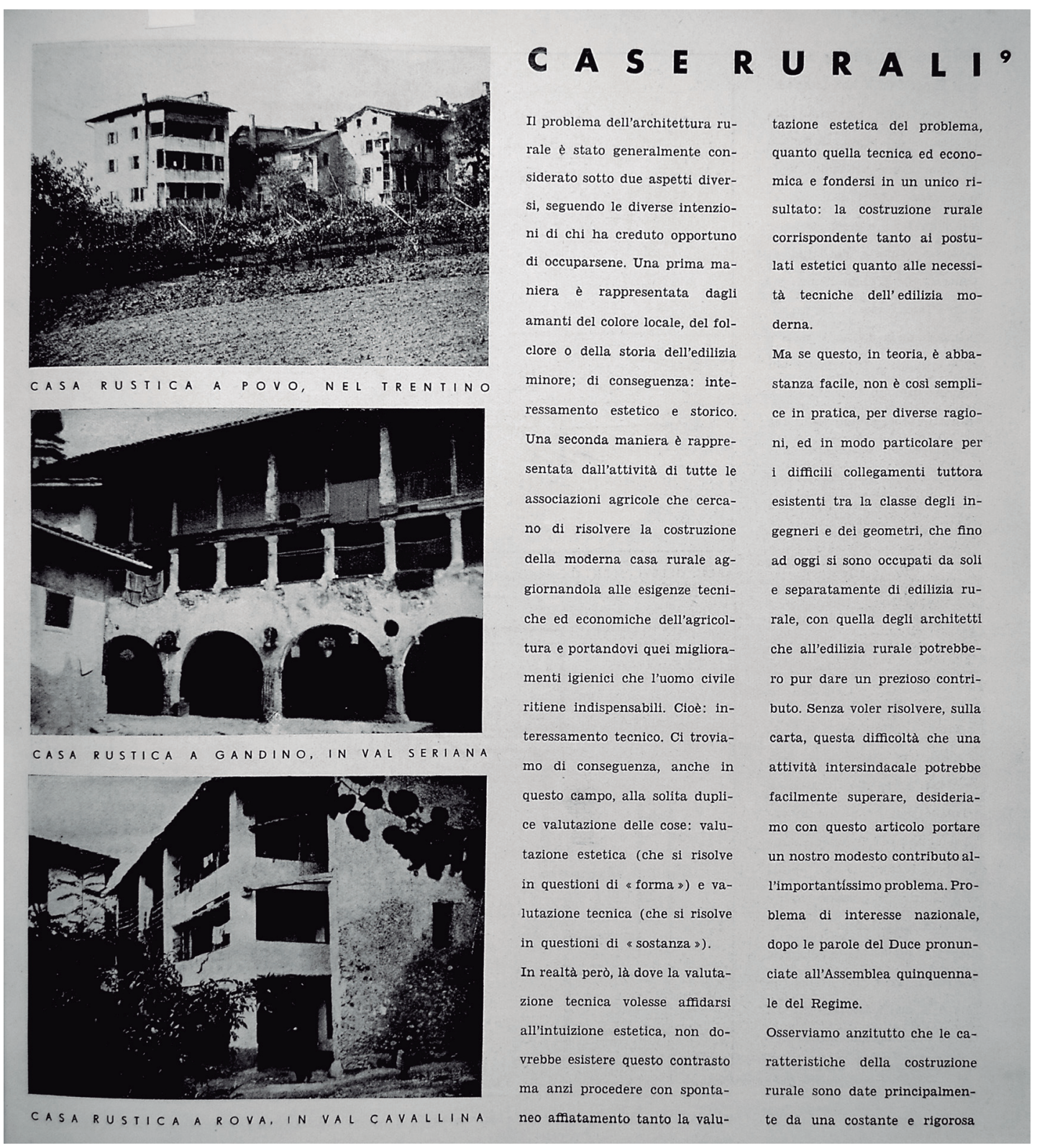



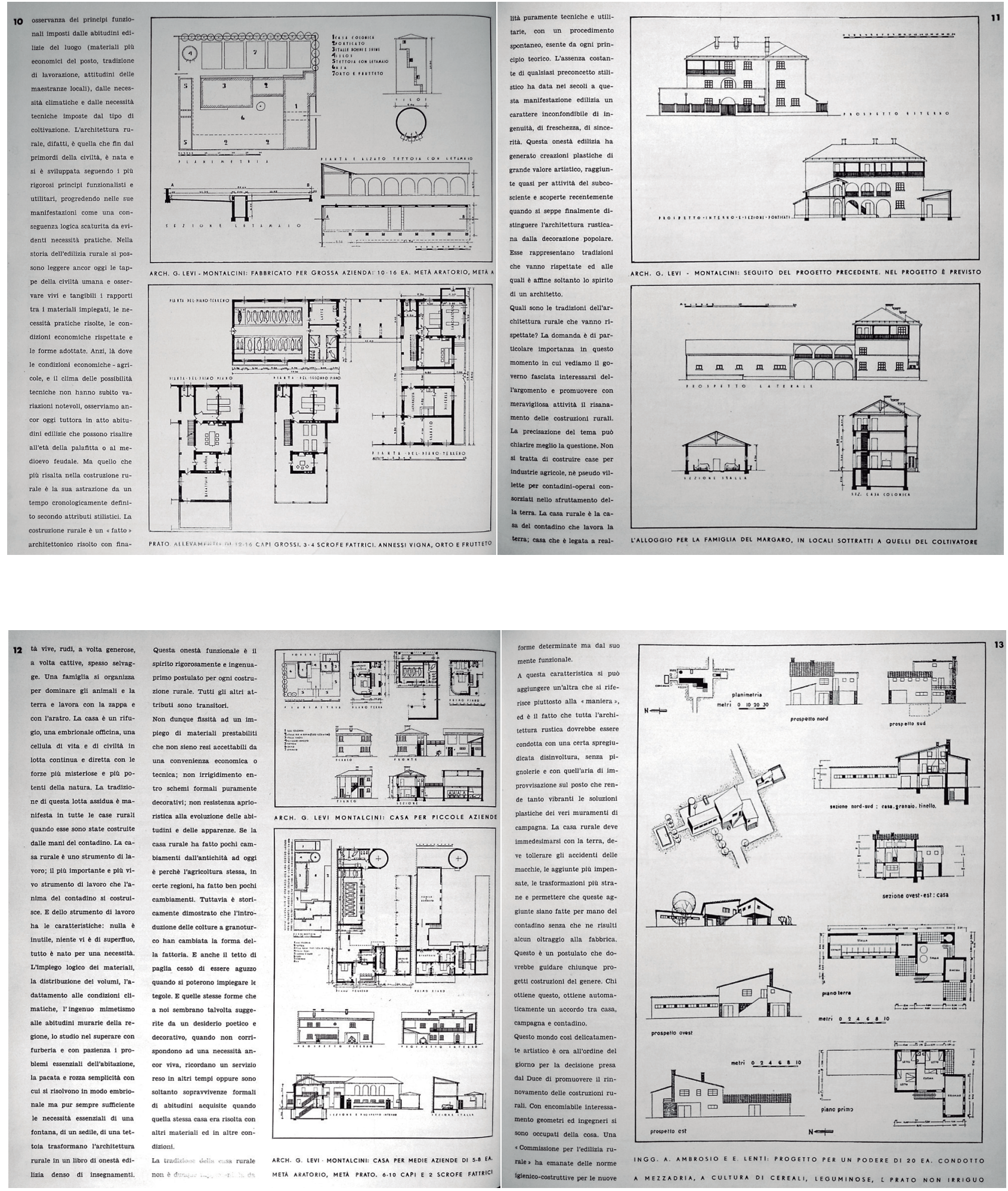


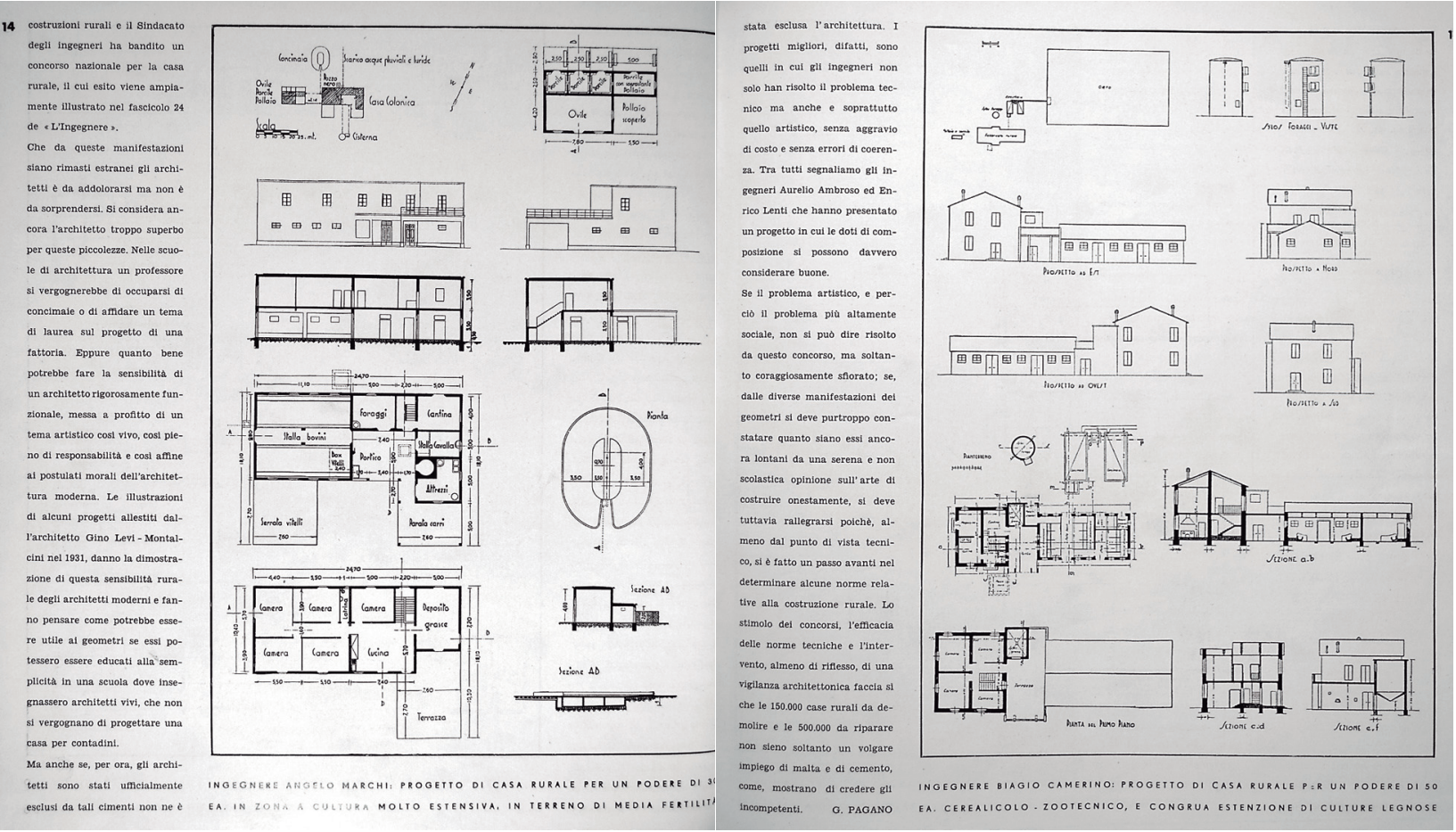

FIG.27-32 "Case Rurale", Giuseppe Pagano

Fonte: revista Casabella, nㅇ, 1935, p.10-15 


\section{$\begin{array}{llllllllllllllllll}{ }^{16} & \text { A } & \mathbf{R} & \mathbf{C} & \mathbf{H} & \mathbf{I} & \mathbf{T} & \mathbf{E} & \mathbf{T} & \mathbf{T} & \mathbf{U} & \mathbf{R} & \mathbf{A} & \mathbf{R} & \mathbf{U} & \mathbf{R} & \mathbf{A} & \mathbf{L}\end{array}$}

Cento anni or sono quando John Ruskin parlava della casa rurale italiana, si soffermava «con piacere sulle modellature cadenti dalle finestre e sui capitelli scolpiti delle colonne d'angolo in contrasto, le une con le tenebre senza vetri dell'interno, le altre con la lacera e sudicia confusione di panni sparsi all'intorno ». Ma pur in questa sua romantica adorazione del pittoresco l'illustre grafomane, parlando della

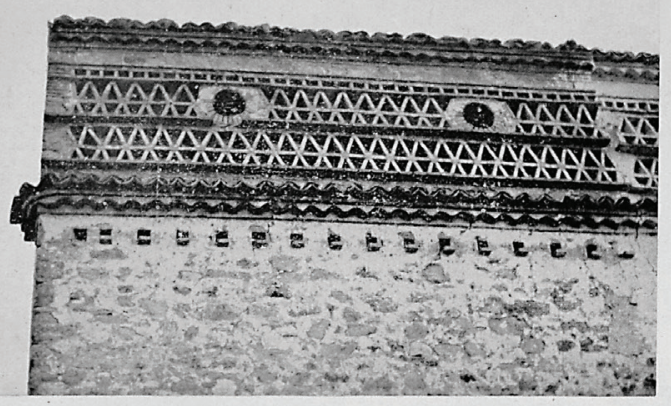

CORNICE DI AEREAZIONE E COLOMBAIA IN UNA CASA RURALE PRESSO CAMPOBASSO

abitazione rurale italiana, riusciva a determinare alcune osservazioni che ancor oggi possono servire per chi si accontenta soltanto di un primo esame superficiale. Egli ne esaltava la «semplicità di forma». «Il tetto» egli scriveva nello studio sulla «Poesia dell'Architettura» (1837) «, che è sempre piatto o poco inclinato, non ammette alcuna finestra di soffitta sporgente, nè termina con fantastici pinnacoli: le mura stesse sono ugualmente liscie; nessuna finestra ad alcova, scolpita, come si incontrano perpetuamente in Germania, in Francia, o nei Paesi Bassi, dà varietà alle loro facciate bianche. E questa semplicità è forse l'attributo principale per il quale la casa rurale italiana raggiunge la grandiosità di carattere, che desideravamo e attendevamo. Tutto ciò che è fantastico di forma e frivolo nei particolari, annichila l'aria aristocratica d'una costruzione: distrugge subito la sua semplicità e la sua grandezza, oltre a destare, come avviene quasi sempre, associazioni di specie bassa e meschine. La casa rurale italiana assume, con la sua semplicità, l'«air noble » delle costruzioni di un ordine superiore; e, benchè eviti ogni ridicola imitazione in miniatura di un palazzo, sdegna i più umili attributi del « cottage». L'ornamentazione che acquista è dignitosa; non ridicole facciate, non insensati travi nodosi. Mentre non ha nulla di inadatto all'umiltà dei suoi abitatori, vi è nella sua aria una dignità generale, che armonizza in modo bellissimo con la nobiltà degli edifici vicini e con la gloria del paesaggio circostante $\gg$.

Queste annotazioni, scritte nel 1837, testimoniano come allora l'architettura rurale italiana non era ancora contaminata da atteggiamen-

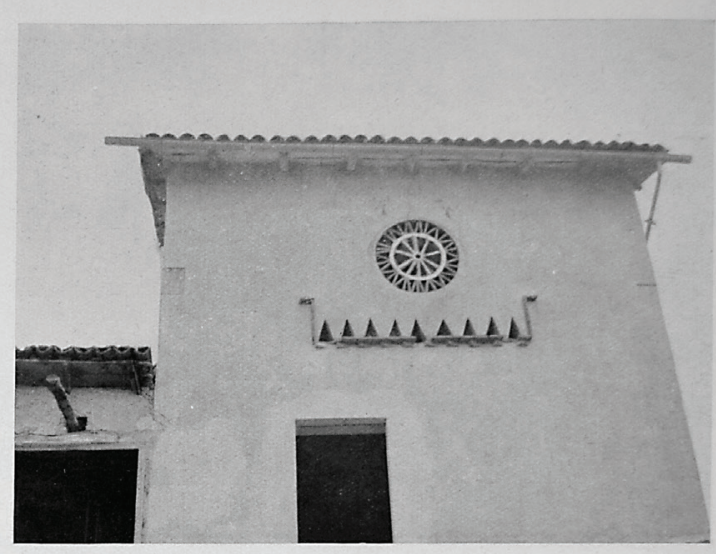

TORREITA COLOMBAIA CON ROSONE DI AEREAZIONE IN UNA CASA ABRUZZESE

ti irrazionali. Oggi tale solida aderenza alla realtà del clima, alla economia agricola e alla onestà costruttiva non è sempre rispettata. Finchè era il contadino, che si murava la propria dimora o finchè il fattore, per antiche abitudini rispettate e sempre collaudate dalla prova dei fatti, sovraintendeva alla progettazione delle nuove cascina, l'architettura rurale procedette su un binario strettamente logico, assumendo quasi il valore di una manifestazione del subcosciente. Con l'estendersi delle cognizioni tecniche, con l'influenza (spesso esteticamente perniciosa) degli esperti rurali innamorati dal falso colore locale, con il pudore romantico di cui diedero prova molti costruttori che si credettero obbligati a trasformare in villini le fattorie o in villaggi medioevali i moderni cascinali industrializzati, l'architettura rurale ha corso il pericolo di perdere il suo immenso valore di costruzione $\&$ pura », astilistica, funzionale. Contro questo pericolo non sono mai insorti i sovraintendenti dei monumenti. Soltanto la realtà economica e la legge stessa della vita provvedono affinchè la rettorica non prevalga. A dispetto dei romantici, anche la forma del silos entra oggi a far parte del quadro rurale, architettonicamente plastica come quella del solenne campanile cilindrico della chiesa di Pomposa. 


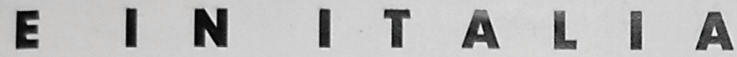

Ma questo discorso, se può riferirsi in certo modo a qualche lato della mostra di architettura rurale che, assieme all'architetto Daniel, sto preparando per la prossima Triennale, serve soltanto a dimostrare come sia costantemente viva, nell'architettura rurale, la massima indipendenza da ogni influenza stilistica. Se esiste, anzi, un libro mastro del dare e dell'avere siamo perfettamente convinti che questo bilan-

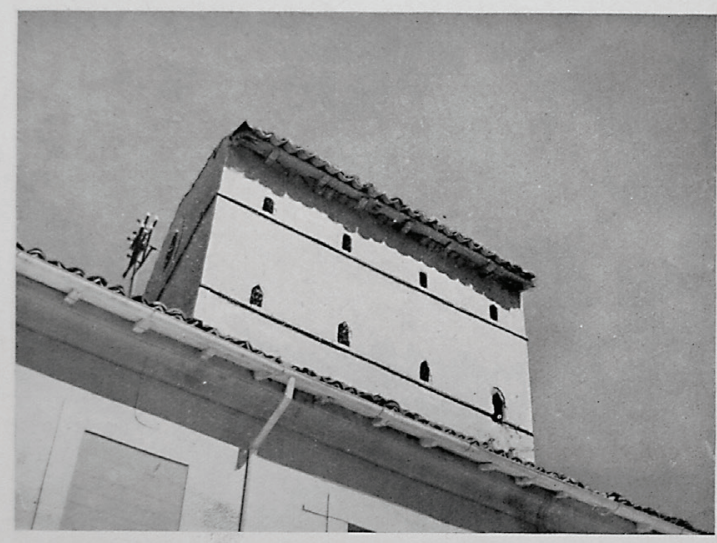

COLOMBAIA A DUE PIANI IN UNA ABITAZIONE DELLA CAMPANIA

cio sia in attivo per l'architettura rurale. Esistono innegabilmente delle costruzioni rurali che stanno ai margini della pura funzionalità e che non si spiegano completamente senza un riflesso di composizione. Ma gli elementi di composizione non sono obbligati all'architettura stilistica, corrispondono piuttosto ad evoluzioni, a deformazioni o a sopravvivenze di soluzioni già elaborate dall'architettura rurale. Tipiche in questo senso sono le due costruzioni che si illustrano nelle pagine seguenti: la casa di Cori e la cascina di Ferentino. La prima è una espressione fantastica dove i valori plastici assumono una intensità quasi mostruosamente voluta. La energica indipendenza da ogni cànone, la sua violenza di chiaroscuro, la sua sdegnosa e maestosa crudezza fanno di questa casa miserabile un capolavoro d espressione. Vi è in germe tutta la ribellione antiaccademica e vi si può ricavare il valore di un ritmo modernissimo. Tanto è espressivo il suo stato di ribellione che sembra intenzionale, cioè stilistico. L'altra casa, quella di Ferentino, è al lato opposto dei rapporti con uno schema stilistico. Qui si sente una cadenza e una simmetria che a prima vista possono far credere ad una villa decaduta. Ma l'assenza di un ingresso centrale spiega che non si tratta di una villa; le due scale esterne dimostrano che la casa è fatta per due famiglie e questo è motivo del ritmo simmetrico; l'assenza di ornatí parla in favore di una costruzione integralmente rurale. Tuttavia essa è effettivamente al limite di una confessata intenzione architettonica. E' il contadino che è diventato stilista o l'architețto di città che ha influenzato qualche onesto capomastro? A questi dubbi non sempre si può rispondere.

Questa casa e le altre che qui si illustrano si prestano anche ad un'altra constatazione. Se osserviamo la casa di Ferentino vediamo collegati da una cornice i davanzali delle finestre del sottotetto. Questa cornice potrebbe sembrare volutamente decorativa. Essa difatti ricorda il ritmo caratteristico delle costruzioni italiane del primo quattrocento, dove i vuoti delle finestre risultano appoggiati ad una cornice orizzontale continua. Tipico l'esempio di Palazzo Venezia a Roma. Ma se gli esempi stilistici hanno assunto questo caratteristico schema per accettazione di una cornice abitualmente usata, qui vediamo spiegata quella cornice dalla colombaia. E' evidente che la colombaia esige la cornice e offre una ragione inizialmente funzionale a quel collegamento orizzontale che sottolinea le facciate dei palazzi italiani de quattrocento, non all'altezza dei piani (come sarebbe logico se la cornice denunciasse una struttura interna) ma all'altezza dei davanzali, come si era abituati a vedere nelle colombaie. E questa abitudine persiste anche quando la facciata degli ediffci aulici vien decorata con la trabeazione classica: il sommo della cornice dell'architrave decorativo corre a fllo dei davanzali, continuando il medesimo effetto di chiaroscuro e rinunciando a denunciare la struttura dei piani interni. Questa influenza della colombaia rurale sulla casa stilistica è forse la più interessante e tipicamente italiana.

Se qualcuno volesse ancora analizzare le influenze formali esercitate dalla colombaia nella architettura di città e dare cosi altre prove delle influenze dell'architettura rurale sull'architettura stilistica, potrebbe ricordare la colombaia a torre della casa toscana e la nefasta influenza che questa bellissima e utilissima torretta ha esercitato sui villini capricciosetti del romantico liberty. Ma se queste sono degenerazioni di cui è meglio tacere, vorrei che si osservassero i rosoni di aereazione delle colombaie e dei solai per pensare alla loro grande analogia coi rosoni delle chiese e coi disegni cosmateschi. Quando si pensa che sempre, nell'architettura rurale, quando si ha da risolvere un problema di pura aereazione si apre un foro rotondo; quando si pensa al primordiale e spontaneo impiego del mattone, si può immaginare questo sistema di risolvere l'aereazione e la chiusura del foro come antichissimo e legato alla esistenza stessa del mattone e perciò precedente ai ritmi stilistici cui esso somiglia. E questa abitudine puramente funzionale può aver suggeriti quei motivi decorativi di cui noi abbiamo esempi nelle chiese medioevali. GIUSEPPE PAGANO

FIG.33-34 "Arquitettura rurale in Italia", Giuseppe Pagano

Fonte: revista Casabella, no 96, dez. 1935, p. 16-17 

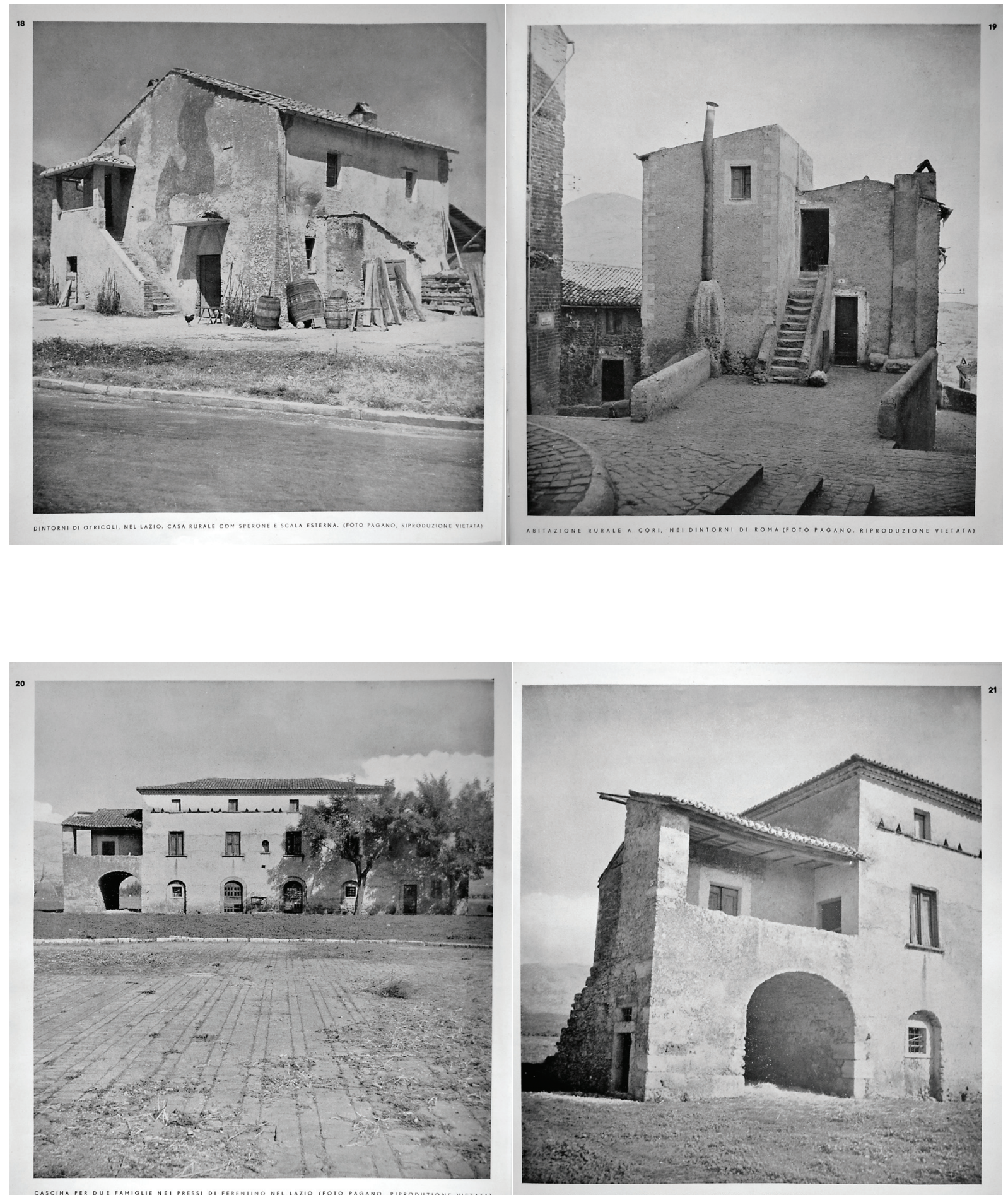


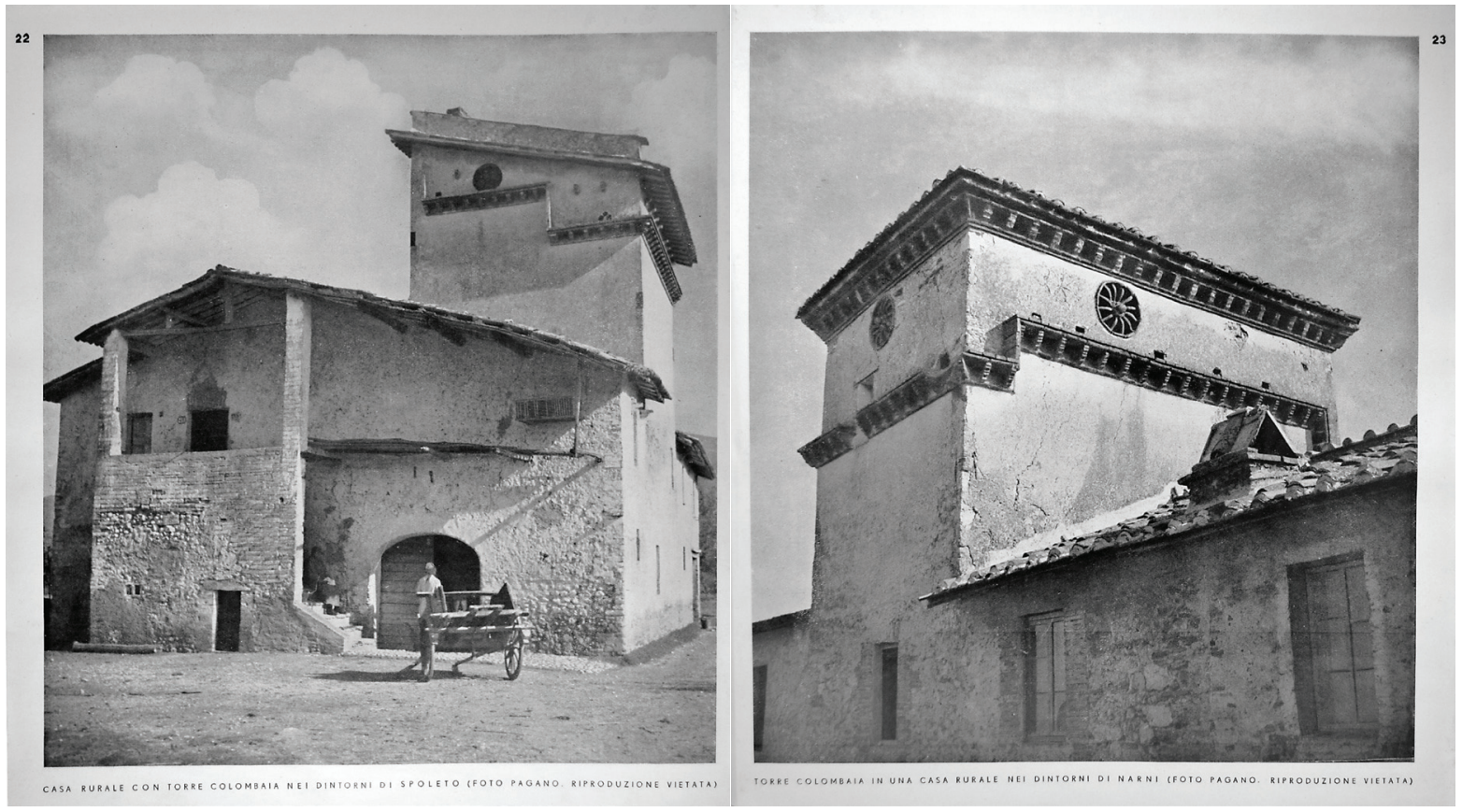

FIG.35-40 "Arquitettura rurale in Italia", Giuseppe Pagano

Fonte: revista Casabella, no 96, dez. 1935, p. 18-23 

CAPÍTULO 2 CONSOLIDAÇÃO 



\subsection{CHEGADA AO BRASIL}

Ao desembarcar no Brasil, em 1946, Lina Bo Bardi esteve junto aos intelectuais formadores da modernidade no país. Por aqui, o "moderno" passava por um processo de construção que, em certa medida, procurava o diálogo entre a arte de vanguarda com origem na modernidade europeia ao qual alguns artistas brasileiros tiveram acesso direto no início do século XX, e a cultura popular, fruto de investigações impulsionadas principalmente pela Semana de 1922.

\footnotetext{
Nesse sentido, o exemplo de Mário de Andrade é paradigmático. Ele protagonizou o "descobrimento" do Brasil, percorrendo nas décadas de 1920 e 1930 o interior do país para registrar manifestações folclóricas num período em que artistas e intelectuais ainda contribuíam diretamente para os quadros do Estado, amparados em um amplo projeto político-cultural que incorporava o elemento popular como dado essencial. A pesquisa e reelaboração da produção musical popular realizada pelo maestro Heitor Villa-Lobos também é uma referência para se analisar o período. As fontes musicais populares coletadas em pesquisas eram retrabalhadas segundo parâmetros eruditos e postas de volta à circulação. ${ }^{68}$
}

$\mathrm{Na}$ arquitetura, a busca pela tradição brasileira estava presente nos estudos de Lucio Costa que, assim como Lina Bo Bardi, os futuristas e racionalistas italianos, descobriu as construções populares em viagens de pesquisa. No caso de Lucio Costa, já engajado no estudo sobre o colonial brasileiro, a descoberta aconteceu em uma viagem encomendada para Diamantina.

${ }^{68}$ MACHADO, Vanessa R. Dos "parangolés" ao "eat me: a gula ou a luxúria?". São Carlos, EESC-USP, tese de doutorado, 2014. p.7-8 
Em 1922, comissionado pela Sociedade Brasileira de Belas Artes, conheci Diamantina. (..)

Lá chegando caí em cheio no passado no seu sentido mais despojado, mais puro; um passado de verdade que ignorava, um passado novo em folha para mim. Foi uma revelação: casas, igrejas, pousada dos tropeiros, era tudo de pau-a-pique, ou seja, fortes arcabouços de madeira - esteios, baldrames, frechais - enquadrando paredes de trama barreada, a chamada taipa de mão, ou de sebe, ao contrário de São Paulo onde a taipa de pilão imperava. ${ }^{69}$

Enquanto no Brasil a procura pelas raízes da cultura e sua contribuição para a construção de manifestações nacionalmente modernas ganhava espaço, na Europa, a destruição das guerras aliada a tomada dos regimes ditatoriais fazia com que o campo de atuação se tornasse cada vez mais restrito.

Após a Segunda Guerra não só o casal Bardi, mas uma série de artistas imigrantes vieram buscar no "Novo Mundo", durante a primeira metade do século XX, oportunidades de trabalho. Em particular os arquitetos tinham como referência a repercussão dada à arquitetura brasileira após a exposição Brazil Builds70 e publicação de seu catálogo. Nas palavras de Lina, "uma esperança real quase cotidiana, não metafísica, na simplicidade das soluções arquitetônicas, nos "hallos" humanos, coisas desconhecidas para uma geração que chegava de muito longe. Naquele tempo, no imediato pós-guerra, foi como um farol de luz a resplandecer em um campo de morte... Era uma coisa maravilhosa." ${ }^{71}$

A bela criança ${ }^{72}$ encontrada pela arquiteta mostrava uma modernidade ainda em formação, com alguns equívocos formais evidentes para ela, mas que parecia querer se encontrar dentro dos verdadeiros ideais modernos, com "um espírito de intransigência e do amor para o homem, que nada tem que ver com as formas exteriores e acrobacias formalísticas." 73

Discordando do que vinha sendo dito nos editoriais europeus, Lina acreditava na evolução da arquitetura moderna brasileira justamente por estar fora do caminho da academia, colocando a prova suas próprias referências e conservando a poesia peculiar do país.

\footnotetext{
${ }^{69}$ COSTA, L. Registro de uma vivência. São Paulo: Empresa das Artes, 1995, p.27

70 Publicação da exposição sobre a arquitetura moderna brasileira realizada pelo Museum of Modern Art de New York em 1943. GOODWIN, Philip L. Brazil Builds: Architecture Old and New: 1652-1942. New York: Museum of Modern Art, 1943.

71 FERRAZ, 1993, p.12

72 Referência ao artigo: BARDI, Lina Bo. "Bela criança”. Habitat, São Paulo, no2, jan./ mar. 1951

73 BARDI, Lina Bo. "Bela criança”. Habitat, São Paulo, no2, jan./ mar. 1951, p.3
} 
"Esta falta de polidez, esta rudeza, êste (sic) tomar e transformar sem preocupações, é a força da arquitetura contemporânea brasileira, é um contínuo possuir em si, entre a consciência da técnica, a espontaneidade e o ardor da arte primitiva."74

Com este espírito, Lina Bo Bardi deu início a consolidação de seu olhar sobre um campo vasto de possibilidades encontrado no país.

74 BARDI, Lina Bo. “Bela criança”. Habitat, São Paulo, no2, jan./ mar. 1951, p.3 


\subsection{A CULTURA POPULAR NA REVISTA HABITAT}

Lina Bo Bardi e Pietro Maria Bardi se instalaram em São Paulo, onde Pietro teria a missão de dirigir o Museu de Arte Moderna a convite de Assis Chateaubriand ${ }^{75}$. Inaugurado em 1947, o Museu cuja proposta era "de formar uma atmosfera, uma conduta apta a criar no visitante a forma mental adaptada à compreensão da obra de arte" não faria sentido "a distinção entre uma obra de arte antiga e uma obra de arte moderna" ${ }^{\prime 76}$, portanto, não caberia a denominação de Museu de Arte Moderna, mas sim Museu de Arte, como foi logo determinado por seu novo diretor.

É nesse novo sentido social que se constituiu o Museu de Arte de S. Paulo, que se dirige especificamente à massa não informada, nem intelectual, nem preparada. ${ }^{77}$ (...) não é um Museu de Arte Antiga nem um Museu de Arte Moderna - é Museu de Arte, e busca formar uma "mentalidade para compreensão de arte"78

A experiência no Museu de Arte de São Paulo priorizou a democratização do acesso à arte e à cultura em sua programação de atividades e exposições, seguindo um modelo mais aproximado ao dos museus americanos, incorporando o aspecto didático às suas atividades. Neste contexto, foram promovidas as Exposições Didáticas com intuito de instruir um público ainda não habituado com as obras de arte aos moldes do que ocorria no Studio d'Arte Palma em Roma. ${ }^{79}$

\footnotetext{
${ }^{75}$ Assis Chetaubriand (1892-1968), foi um influente jornalista, empresário, mecenas, advogado e político brasileiro.

${ }^{76}$ BARDI, Lina Bo. “O Museu de Arte de São Paulo - A função social dos museus”, Habitat, São Paulo, no1, out-dez 1950, p.17

77 BARDI, Lina Bo. "O Museu de Arte de São Paulo - A função social dos museus”, Habitat, São Paulo, no1, out-dez 1950, p.17

${ }^{78}$ BARDI, Lina Bo. "O Museu de Arte de São Paulo - A função social dos museus”, Habitat, São Paulo, no1, out-dez 1950, p.17

79 FERRAZ, 1993, p.46
} 
O envolvimento com a elaboração de um novo conceito fez com que Lina propusesse soluções para as lacunas estruturais observadas por ela dentro dos espaços do museu, que inicialmente estava localizado no centro da cidade, na rua 7 de abril. Tudo foi devidamente adequado pela arquiteta, desde a divisão de ambientes e o tratamento para a qualidade de conservação das obras até a expografia e a produção de cadeiras que atendessem às necessidades das novas atividades ${ }^{80}$. Este conceito de museu seguiu para a nova sede do MASP construído posteriormente na Avenida Paulista, e incorporou também uma arquitetura adequada a esta proposta.

Integrando as atividades do MASP estava ainda o Instituto de Arte Contemporânea (IAC), cuja função era oferecer atividades relacionadas a vários segmentos das artes, como desenho, desenho industrial, fotografia, pintura e música. Em 1950 foi lançada a revista Habitat ${ }^{81}$, criada com o objetivo de divulgar as atividades do Museu e do Instituto e também para servir como ferramenta de debate acerca da cultura moderna e das culturas tradicionais do país aos moldes do que havia sido praticado por Lina e Pietro nos editoriais italianos.

Esta influência italiana sobre a revista foi a chave para a peculiaridade de seus conteúdos. Dentro do contexto brasileiro, onde o debate sobre modernidade da arquitetura encontrava-se latente em publicações produzidas principalmente no Rio de Janeiro e em São Paulo ${ }^{82}$, os temas restringiam-se aos projetos arquitetura e decoração elaborados por arquitetos, "Uma revista que colocasse os temas da arquitetura junto com artigos sobre arte, cinema, fotografia, teatro, dança, literatura e que se pautasse na formação de uma cultura nacional moderna, só a Habitat." ${ }^{33}$ Lina Bo Bardi assumiu a direção da revista do número 01 ao número 09 e, posteriormente, dirigiu os números 14 e 15 junto com Pietro Maria Bardi. ${ }^{84}$

\footnotetext{
80 “Nós viramos São Paulo inteiro e não achamos ninguém que tivesse uma cadeira moderna. Fomos obrigados a desenhála." Lina em FERRAZ, 1993, p.50

${ }^{81}$ Estudos mais aprofundados sobre a revista Habitat podem ser encontrados nos seguintes trabalhos: GRINOVER, Marina Mange. Uma ideia de arquitetura: escritos de Lina Bo Bardi. São Paulo, FAUUSP, Dissertação de Mestrado, 2010

STUCHI, Fabiana Terenzi. Revista Habitat: um olhar moderno sobre os anos 50 em São Paulo. São Paulo, FAUUSP, Dissertação de Mestrado, 2006

82 "O panorama da produção da Habitat no campo editorial em São Paulo não era grande. Aqui, editava-se na época as revistas Acrópole (1938-1965), Pilotis (1949-1949), em mais tarde AD (1953-1958), Bem Estar (1958-1960), Arquitetura Mackenzie (1958-1958) e a Revista do IAB (1954-1961). (...)

No Rio de Janeiro, a produção sobre arte e arquitetura era mais antiga, com edições desde 1921, como a revista Arquitetura do Brasil, que no cenário carioca colocava a arquitetura em par com o debate da arte moderna. Podemos mencionar ainda as revistas Ante-projeto (1945-1959), Brasil arquitetura contemporânea (1953-1958), Forma (1954-1955) e Módulo (19551968). Verificamos que o debate sobre arquitetura até 1969 com o Al5 e a censura editorial deu-se, também no Brasil, além destas editorias específicas nos jornais diários." (GRINOVER, 2009, p.149)

83 GRINOVER, 2009, p.149

84 PEREIRA, Juliano. Lina Bo Bardi. BAHIA, 1958 - 1964. Uberlândia, EDUFU, 2008. p. 39
} 
O "Prefácio" do primeiro número da revista já anunciava a busca por uma arte nacional constituída de forma híbrida entre diversos agentes, de maneira que "todos os que contribuíram, continuam contribuindo e participam de alguma forma da arte no Brasil, terão as suas atividades registradas em "Habitat" com o empenho de quem sabe apreciar o que de mais característico tem o país." 85

Assim, as chamadas "arte erudita" e "arte popular" dividiam as páginas da publicação e seus conteúdos assumiam igual importância na construção de um debate sobre a formação da cultura brasileira. Esse posicionamento, já praticado nos editoriais italianos - sobretudo nas revistas Domus e A - Cultura della Vita - retornava em Habitat reativando o desejo de conciliação entre tradição e modernidade como forma de afirmação da originalidade da arte nacional e evolução das restritas definições de arte e cultura estabelecidas até então.

Os artigos dos primeiros quinze números de Habitat tratavam de uma geografia própria que compreendia os eixos São Paulo-Rio de Janeiro e Norte-Nordeste. Pereira (2007, p.41) ensaia uma justificativa para este fato considerando por um lado o desenvolvimento cultural capaz de apresentar produtos modernos como era o caso da arquitetura desenvolvida no Rio de Janeiro e em São Paulo e, por outro, as matrizes atribuídas às culturas presentes no interior dos Estados do Sudeste e no eixo Norte-Nordeste.

Curiosamente não é possível reconhecer como um dos focos privilegiados da atenção da revista a região Sul do Brasil, isto é, Paraná, Santa Catarina e Rio Grande do Sul. Apenas o Norte do Paraná comparece, porém mais como parte do imaginário sobre o interior e os limites do Estado de São Paulo, do que explorando as suas características particulares. Para a explicação de tal exclusão, aqui se poderia arriscar como justificativa o fato de esses Estados, por um lado, não terem atingido o nível de desenvolvimento econômico e urbano e, consequentemente, artístico e cultural que atingira a região Sudeste e, por outro, do ponto de vista de sua cultura tradicional, estarem ligados, diferentemente da região Norte e Nordeste do País, à matriz europeia, de onde aflui a maior parte de seus habitantes-migrantes - ao contrário da constituição do Norte e Nordeste, com uma base cultural proveniente de uma outra matriz que Lina, alguns anos mais tarde, definiria como ligada ao Oriente, tendo em sua origem bases ameríndias e africanas.

\footnotetext{
A Habitat continuou a ser editada mesmo após saída de Lina e Pietro da direção da revista, mas para este estudo interessam os assuntos editados nos primeiros quinze números, conforme segue.

85 PREFÁCIO. Habitat, São Paulo, no1, out-dez 1950, p.1
} 


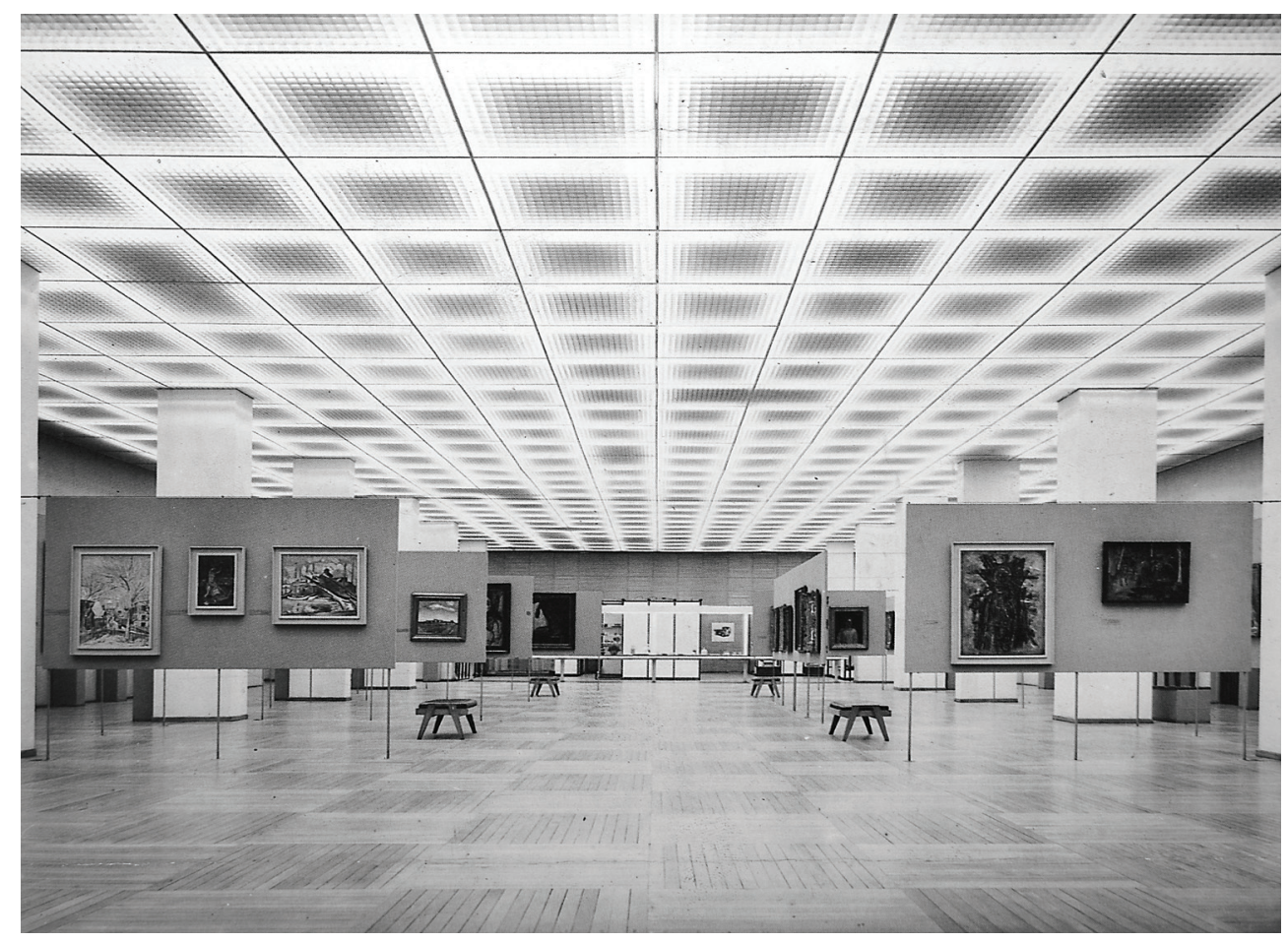

FIG.41 Pinacoteca do Museu de Arte de São Paulo, 1950

Fonte: FERRAZ, 1993, p.47
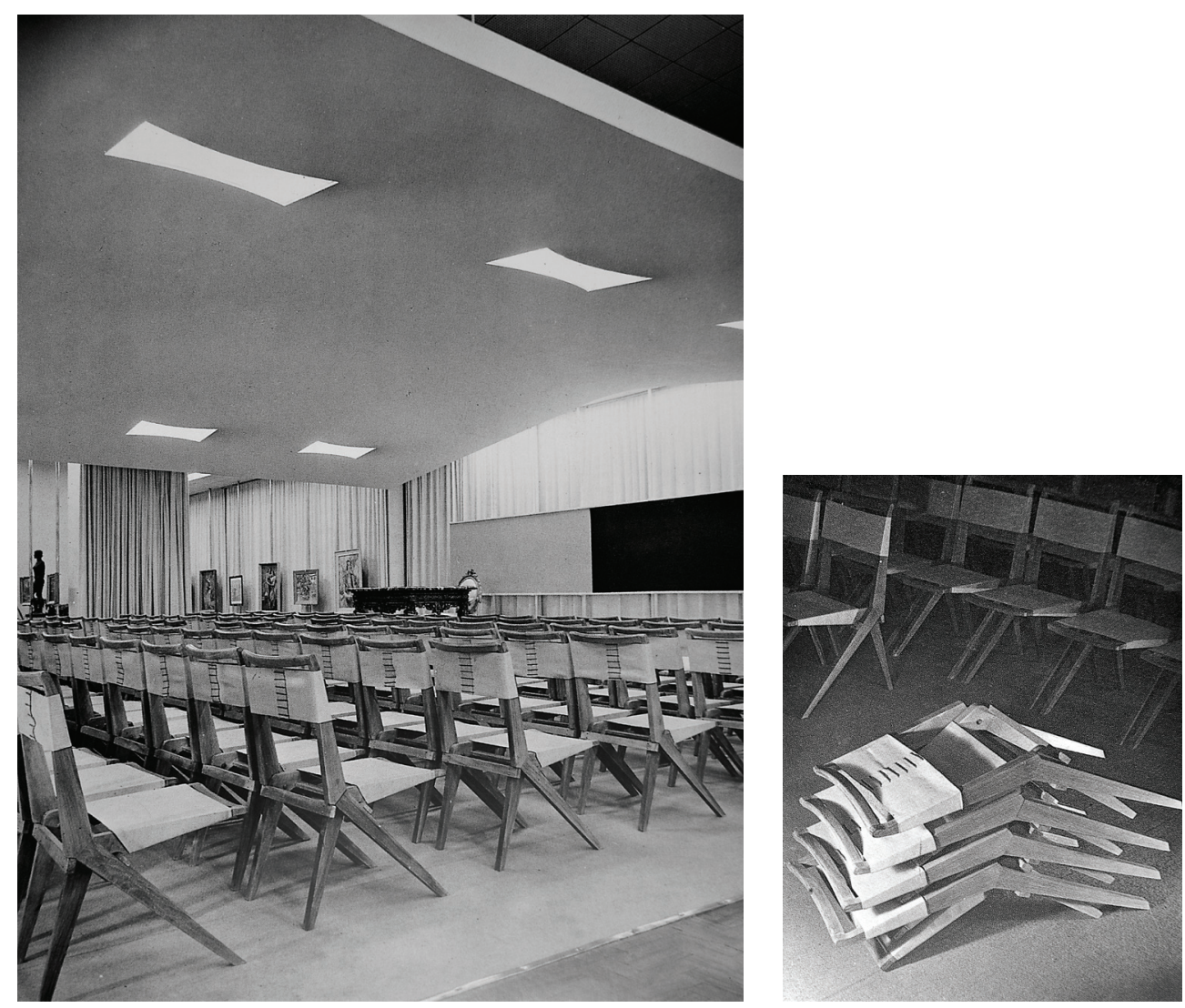

FIG.42-43 Auditório do Museu com cadeira projetadas pelo Studio Palma. Ao lado, empilhamento das cadeiras Fonte: FERRAZ, 1993, p.50 
FIG.44 Capa da revista Habitat $\mathrm{n}$ - 1 Fonte: FERRAZ, 1993, p.64

\section{HABITAT}
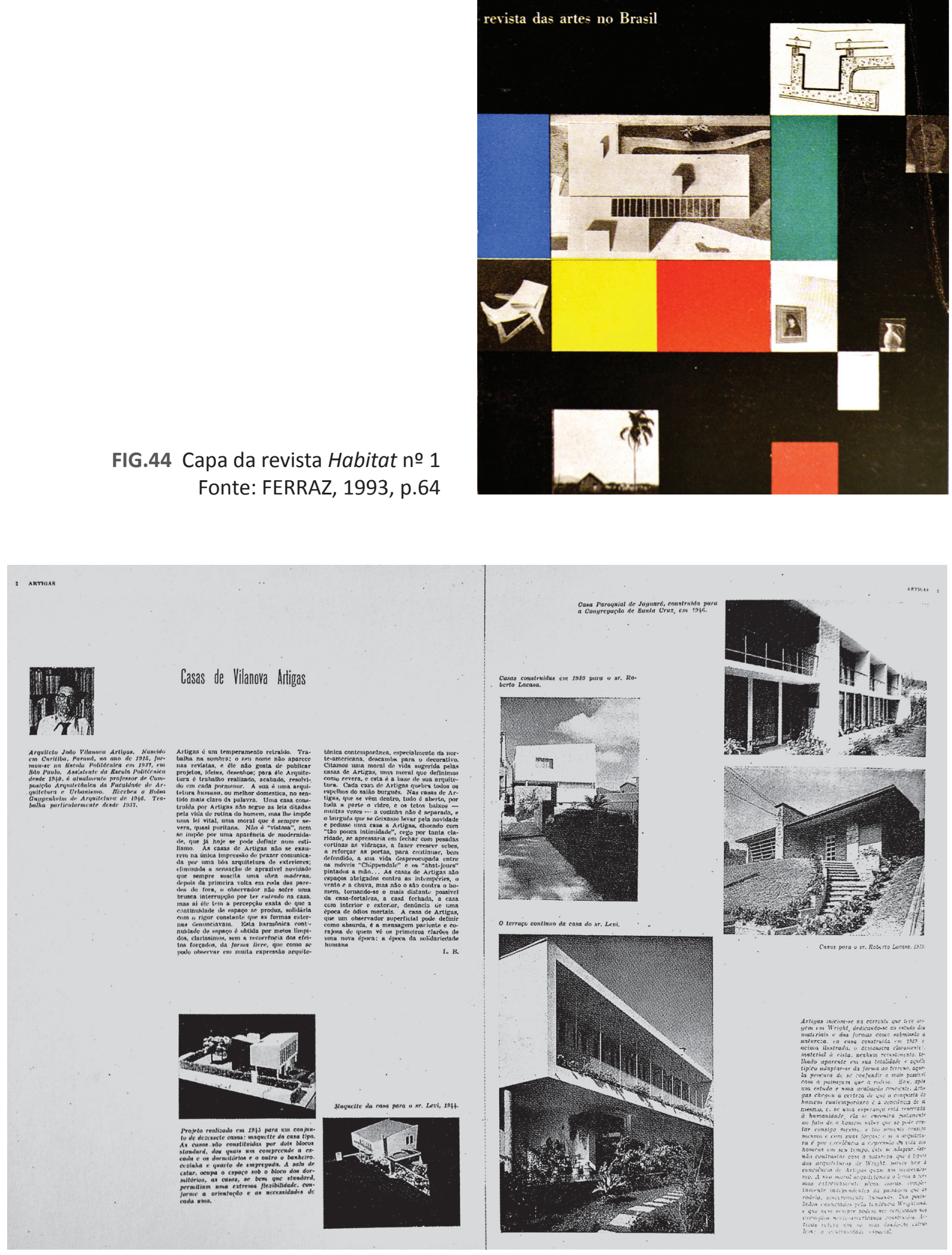

FIG.45 Páginas da revista Habitat $\mathrm{n}$ o 1 Fonte: FERRAZ, 1993, p.64 
As parcerias firmadas durante os primeiros quatro anos em que Lina esteve envolvida com a publicação da revista, as atividades realizadas no Museu de Arte de São Paulo e suas viagens de pesquisa pelo país foram determinantes para o estabelecimento deste recorte para os seus trabalhos posteriores.

\section{ARTE E ARQUITETURA PARA A VIDA DO HOMEM}

A questão da arte e da arquitetura feita "para a vida do homem" trazida por Lina teve origem nos estudos teóricos de Croce, que influenciaram a formação do pensamento racionalista italiano; na questão da hegemonia elaborada por Gramsci; na crítica ao estilo Neoclássico e a ornamentação excessiva; nos aprendizados junto a Gio Ponti sobre a racionalização da produção; na ideia da criação intuitiva de soluções racionais primitivas percebida por Pagano em seus estudos sobre a "arquitetura menor"; e, sobretudo, na tomada de consciência sobre a necessidade da simplificação e na atenção às necessidades do homem acima de qualquer rigor estilístico pré-estabelecido.

De par com a elite arquitetônica de seu país de origem, Lina Bo Bardi traria na bagagem ao Brasil um olhar peculiar sobre a formação de uma cultura genuinamente moderna e amalgamada aos homens. Uma postura para a formação de um gosto pelo ambiente moderno, simples, racionalizado e funcional que partisse de referências das raízes culturais e não de uma ação imposta e externa. ${ }^{86}$

O texto "Para uma nova cultura do homem" 87 de Pietro Maria Bardi, abre a revista Habitat 02 apresentando um ideal a ser estabelecido para os museus através de trechos do texto de um relatório publicado pela Unesco ${ }^{88}$ que, segundo Bardi, recomenda que o museu seja tratado como mediador da cultura entre o especialista e o público geral e não apenas como um lugar espetacular e turístico como ocorria no passado.

Precisa transformar o homem dedicado à cultura. Isto é, a de estimular um processo mental no especialista, em virtude do qual êste (sic) possa vencer o isolamento em que as próprias exigências da metodologia e a ampliação quantitativa crescente dos materiais tendiam a confina-lo e em virtude do qual sejam destruídas as hesitações

\footnotetext{
86 GRINOVER, 2010, p.31

87 BARDI, Pietro Maria. Para uma nova cultura do homem. Habitat, São Paulo, no2, jan-mar 1951, p.1

88 Dentro do contexto da criação da própria Unesco (United Nations Educational, Scientific and Cultural Organization) após o fim da 2a Guerra e o posterior estabelecimento do ICOM (International Council of Museums) entre 1946-1947, que passaram a produzir publicações acerca da prática da "preservação e divulgação do patrimônio natural e cultural mundial, do presente e do futuro, tangível e intangível". ICOM Internacional. Portugal, 2015. Disponível em: <http://www.icomportugal.org/pagina,123,152.aspx> Acesso em 05 de janeiro de 2015
} 
os mal entendidos e as asperezas que atuam como compartimentos estanques entre o cientista e o público. O cientista deverá perder a atitude e o hábito dos sacerdotes, guarda de um patrimônio misterioso e privativo. Deverá resignar-se a perder as prerrogativas de ermitão em meio às tebaldas (sic), nas quais somente a fascinação abstrata dos materiais e o sentimento cristalizado em peças seriam a expressão de um orgulho privilegiado e desumano. O público, por outro lado será conduzido passo a passo a rica e versatil (sic) condição na qual grupos sociais não se comprimem como massas acéfalas à espera do maná dos oráculos, mas como um organismo vivo, composto por indivíduos vivos. ${ }^{89}$

Este ideal de museu vivo e de caráter educativo refletia o espírito das atividades desenvolvidas no Museu de Arte de São Paulo e posteriormente seguiu incorporado ao Museu de Arte Moderna da Bahia (MAMB) dirigido por Lina Bo Bardi a partir de 1960.

Em Habitat 03, o texto inicial é uma "Carta Aberta"90 escrita por Renato Cirell Czerna ${ }^{91}$ ao Governador do Estado de São Paulo manifestando suas preocupações sobre como a questão da cultura era tratada no Estado. Segundo o autor, esta questão estava sendo colocada de forma secundária diante dos problemas práticos da vida e acabava por privar o povo de sua própria cultura. Para Czerna, naquele momento, a cultura para o povo no máximo se aproximava do princípio do Império Romano de "panem et circenses". E dizia ainda que

o problema não é tanto da existência, da realização de uma cultura, de uma vida cultural entre nós, mas sim da autenticidade da sinceridade desta cultura e da vida do espírito. É preciso restaurar uma consciência cultural autêntica, e não tolerar que continue esta atmosfera de "cultura" hipócrita (...). É possível instaurar uma cultura realmente viva, em que o povo esteja integrado e, ao mesmo tempo, no sentido de um humanismo verdadeiro, positivo, concreto e não puramente eruditivo (sic).

\section{(...)}

Os dois aspectos principais dos males que nos afligem (...) podem ser resumidos no seguinte: pratica-se uma "cultura" superficial, erudita e rotineira, à qual a Nação e o povo que a forma, não participam. Há entre esta "cultura" e o povo, uma cisão profunda, e direi mais, uma inimizade e uma incompreensão recíprocas. ${ }^{92}$

\footnotetext{
89 BARDI, Pietro Maria. Para uma nova cultura do homem. Habitat, São Paulo, no2, jan-mar 1951, p.1

90 CZERNA, Renato Cirell. Carta aberta. Habitat, São Paulo, no3, abr-jun 1951, p.1

${ }^{91}$ Renato Cirell Czerna (1922 - 2005). No período em que escreveu para a revista era professor de Filosofia do Direito da Universidade de São Paulo. Em 1958 teve a casa de sua mãe, Valéria Piacentini Cirell, projetada por Lina Bo Bardi.

92 CZERNA, Renato Cirell. Carta aberta. Habitat, São Paulo, no3, abr-mai 1951, p.2
} 
Como alternativa para solucionar o problema desta cisão, ambos os autores concordavam com o potencial cultural do país e com sua afirmação através de atividades que promovessem a discussão e o conhecimento das manifestações de arte e os agentes envolvidos na formação dessa cultura moderna nacional. Tal posicionamento é verificado também na trajetória profissional de Lina Bo Bardi que, por sua vez, carregou a preocupação sobre a importância da comunicação com o público geral para a formação de um gosto moderno desde o seu período na Itália, como já tratado no capítulo anterior.

\section{A PRESENÇA DA CULTURA POPULAR}

A cultura popular esteve presente na revista Habitat em textos que falavam sobre a arte indígena, as cerâmicas do norte e nordeste, a pintura feita pelos pintores primitivos ${ }^{93}$, os objetos fabricados para o uso cotidiano e para os rituais mítico-religiosos, a arquitetura feita pelo arquiteto sem compasso ${ }^{94}$, além das manifestações populares na música, no teatro e no cinema.

Ao colocar os assuntos sobre a cultura popular ao lado de assuntos da arte moderna - também presentes através de diversas manifestações - a revista reforçou seu compromisso com a formação de uma cultura nacional fundamentada na complexidade de suas raízes. Conforme descrito no início do artigo "Nossos instrumentos musicais", na Habitat 07, a divulgação dos produtos populares tinha um objetivo definido dentro da formação dessa cultura.

A nossa revista, que nada tem de etnográfica, mantém-se firme na sua opinião, ou melhor, na sua fé que é a seguinte: o produto popular genuíno (dizem os cientistas: "ergológico") é o germe que contém na sua variedade e expontaneidade (sic) a semente de tôda (sic) a civilização futura, os aspectos de um complexo nacional em elaboração. Eis um ponto em que é essencial acreditar: não se forma uma cultura plástica enquanto não se atinge uma substância originária, expontâneamente (sic) criada por várias populações. O mesmo se poderá dizer com respeito a um grande país em fase de fermentação, em febre de crescimento, como é o caso do nosso, e

\footnotetext{
${ }_{93}$ Referência ao artigo da Habitat 02, chamado "Mais um pintor primitivo", que assim como outros artigos presentes em diversos números da revista, apresenta a produção de um artista do povo

94 Referência ao artigo da Habitat 07, chamado "Construir é viver", cujo texto fala sobre o conhecimento e a prática do arquiteto do povo
} 
aplica-se igualmente às culturas européias (sic). A alta cultura sempre surgiu de fontes populares. $^{95}$

Os objetos populares foram dispostos na revista Habitat como forma de registro sobre a produção dessas várias populações existentes no país, ainda sem definições precisas que os classificassem, mas já mirados sob o olhar crítico desenvolvido durante a experiência italiana de Lina Bo Bardi, sobretudo ao acompanhar as ações e pesquisas de Gio Ponti e Giuseppe Pagano.

A cerâmica é uma das técnicas populares mais recorrentes na revista. A Habitat 02 traz o artigo "Cerâmica do Nordeste" e fala sobre a coleção de Augusto Rodrigues ${ }^{96}$, que possui também ex-votos mostrados na Habitat $01^{97}$. Esses objetos foram recolhidos pelo artista durante vários anos de viagens e resultaram na Primeira Exposição de Cerâmica do Nordeste organizada no Museu de Arte de São Paulo em $1949^{98}$.

O texto diz sobre a capacidade do caboclo ceramista de reproduzir em seus objetos as cenas de seu cotidiano por meio da observação e do domínio de uma técnica primitiva que carrega a tradição popular e que possui uma peculiaridade estética munida de um exagero quase caricaturista. 0 ceramista "age inconscientemente, traduzindo em formas e cores puras, algo que êle (sic) sempre possuiu, porque herdou de seus antigos." ${ }^{\prime 99}$ É destacado ainda que tão importante quanto o conhecimento da tradição no processo de feitura dessas cerâmicas é a manutenção da coincidência entre o ambiente de vida e de criação destes caboclos, pois "Ionge de sua choupana e em conctato (sic) com outros ambientes, perderá qualquer capacidade, pois tôdas (sic) suas capacidades são atmosferas telúricas, são húmus da terra que êle (sic) respira." 100

Tal discurso sobre os processos e resultados vem acompanhado da crítica a um possível "primitivismo forçado" que estaria sendo divulgado em outras revistas apenas para promover artistas, o que ia contra o anseio da Habitat pela busca por uma verdadeira manifestação de arte tradicional, sem interferências externas.

\footnotetext{
95 NOSSOS instrumentos musicais. Habitat, São Paulo, no7, abr-jun 1952, p.42

${ }^{96}$ Augusto Rodrigues (191-1993). O artista pernambucano foi pintor, desenhista, gravador, ilustrador, caricaturista e poeta. MARTINS, Maria Lúcia. Augusto Rodrigues: um educador com arte. Educação Pública. Disponível em: <http://www.educacaopublica.rj.gov.br/biblioteca/educacao/0069_09.html> Acesso em: 03 de janeiro de 2015

${ }^{97}$ EX-VOTOS do nordeste. Habitat, São Paulo, no1, out-dez 1950, p.72

98 ITAÚ Cultural. Enciclopédia Itaú Cultural. Mestre Vitalino. Disponível em:

<http://enciclopedia.itaucultural.org.br/pessoa9523/mestre-vitalino> Acesso em 03 de janeiro de 2015

${ }^{99}$ CERÂMICA do Noroeste. Habitat, São Paulo, no2, jan-mar 1951, p.72

100 CERÂMICA do Noroeste. Habitat, São Paulo, n2, jan-mar 1951, p.72
} 
Procurando cumprir com sua função em chamar a atenção para o valor dos produtos populares, o número 05 da revista traz o artigo "Arte popular" que mostra um vaso feito de "papel crepe, amarelo e verde com flores e duas aves confeccionadas de retalhos de algodão estampado."101 A imagem deste objeto, que conforme a legenda, foi "executado por caboclos do Ceará" serviu para levantar a questão sobre qual o sentido do olhar atento para um objeto como este, que em um primeiro momento pode ser julgado sem valor para a arte.

não queremos afirmar que êste (sic) objeto modesto seja uma "obra de arte", objeto tão perto ao máu (sic) gôsto (sic) que bastaria um nada para perde-lo; queremos sòmente (sic) continuar documentando o fato que, aquêles (sic) sem o luxo de se ocupar de idéias (sic) e lugares comuns da assim chamada civilização, rotina, bom gôsto (sic), aqueles que não puderem sustentar esses luxos, vivem perto das coisas e continuam vendo-as e sentindo-as com o que pode ser paragonado à maneira do sentir das crianças, ingenuidade, que nós, porém, chamamos de poesia. ${ }^{102}$

Essa poesia contida no vaso de papel crepe, que tem muito mais a ver com o saber fazer com o que se tem a mão do que com o objeto acabado em si, pode ser apontado como um dos focos do olhar de Lina diante dos objetos populares a que teve acesso através de suas pesquisas ou mesmo através das pesquisas de outros divulgadas nas publicações em que esteve envolvida. Isso sem perder de vista os atributos modernos de funcionalidade e racionalidade também destacados por diversas vezes pela arquiteta em objetos e arquiteturas de fatura popular.

${ }^{101}$ CERÂMICA do Noroeste. Habitat, São Paulo, no2, jan-mar 1951, p.72

102 ARTE popular. Habitat, São Paulo, no5, out-dez 1951, p.55 


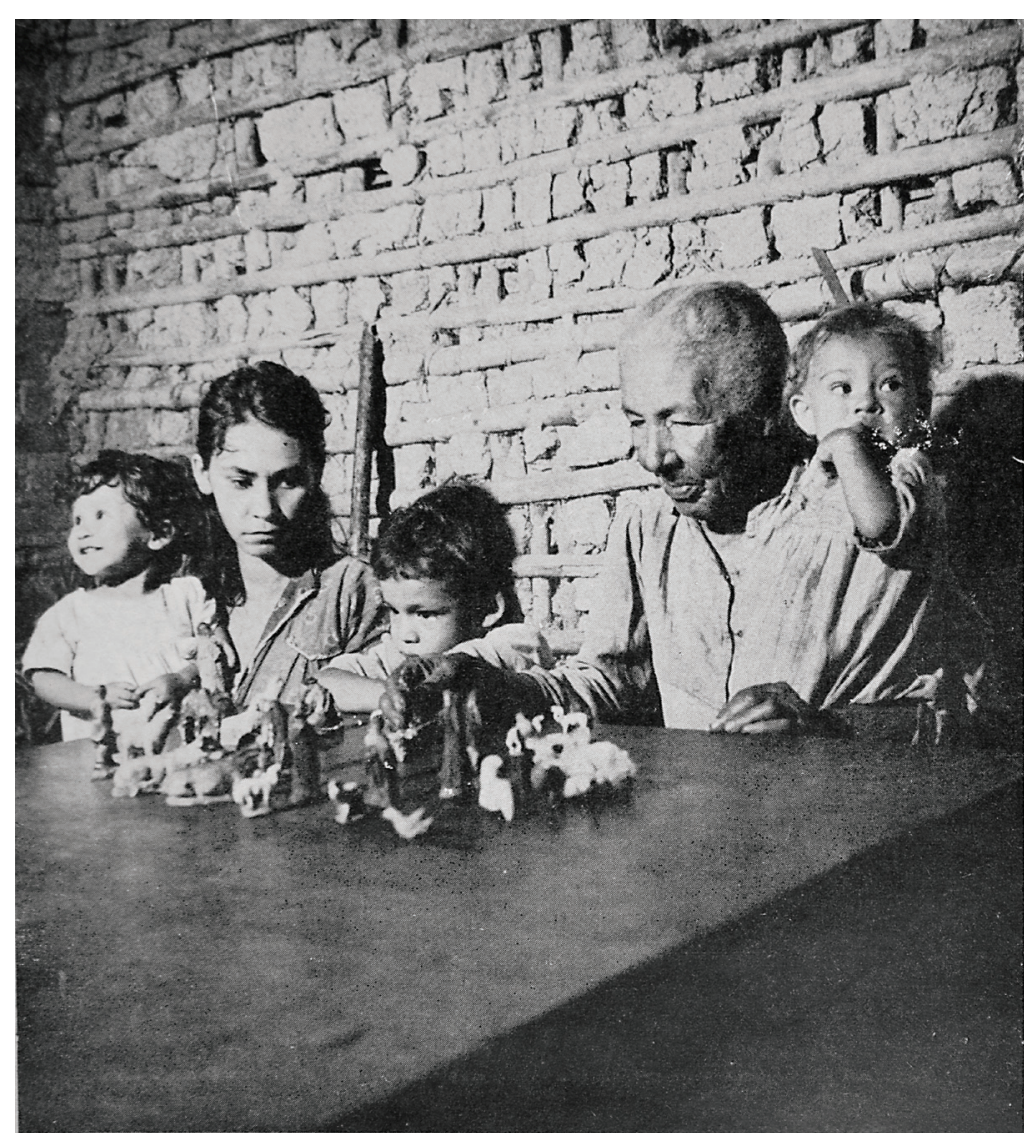

FIG.46 Família de ceramistas Fonte: HABITAT, 1951, p.72
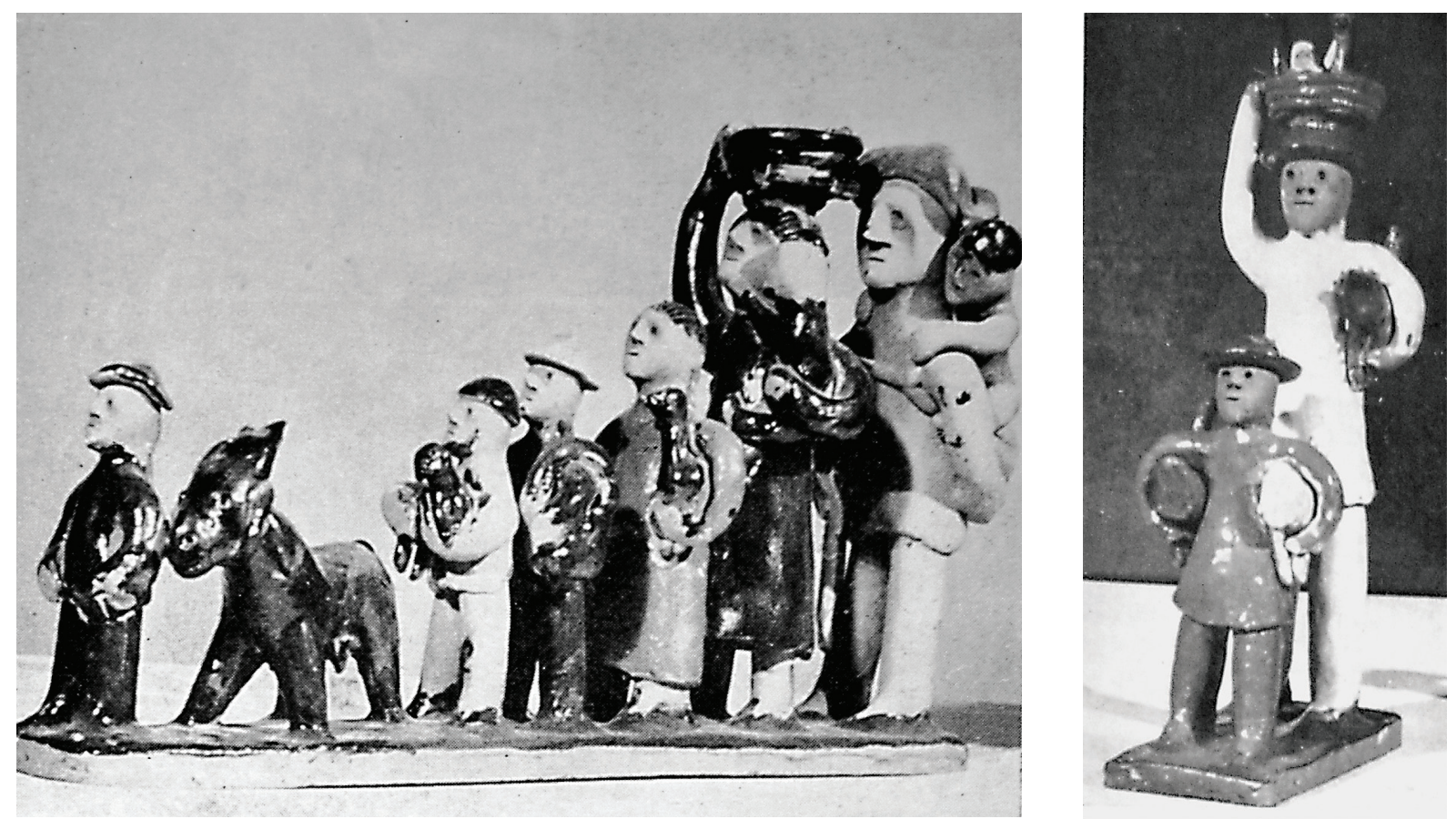

FIG.47-48 "Família do nordeste" e "Ao mercado" - Imagens de esculturas de cerâmica da coleção de Augusto Rodrigues que acompanham o artigo "Cêramica do Nordeste" Fonte: HABITAT, 1951, p.74-75 


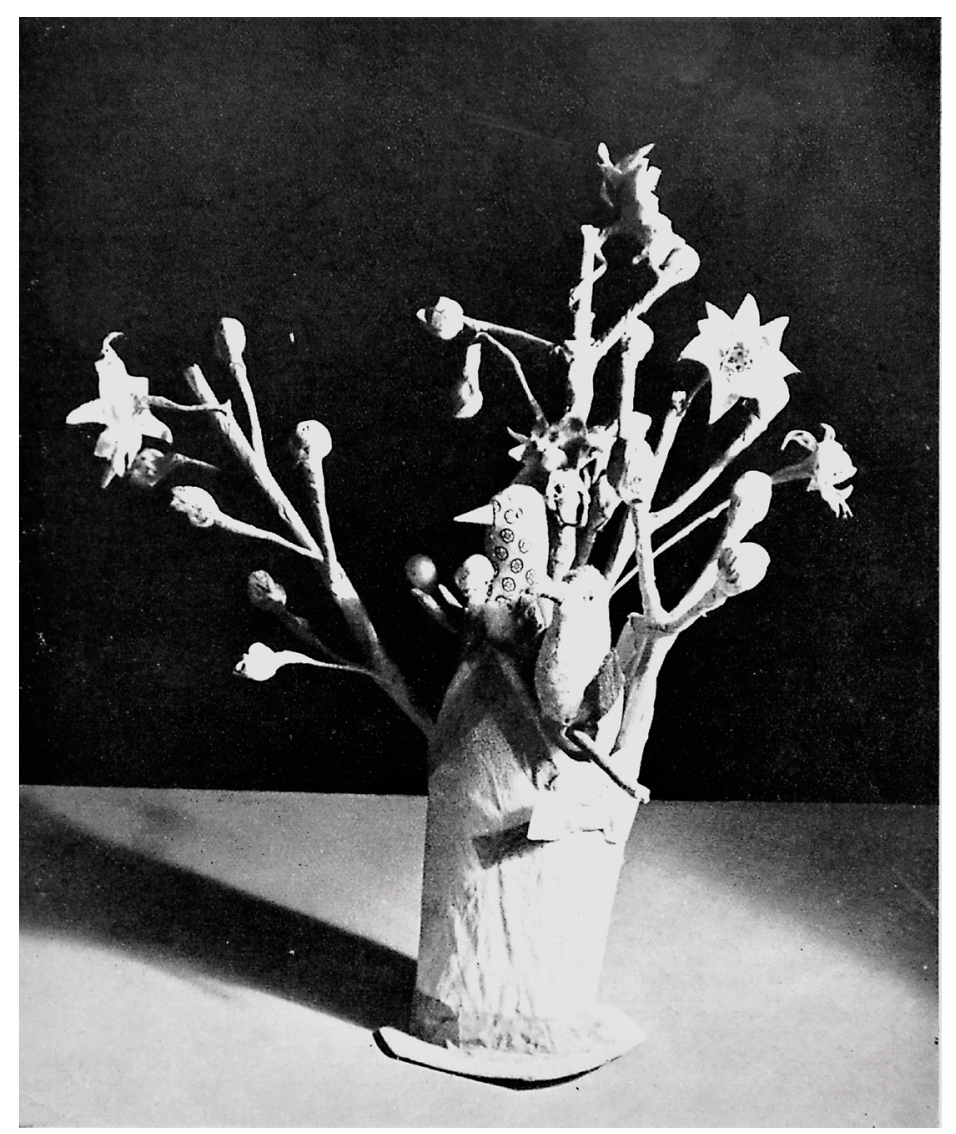

FIG.49 "Vaso de flores, executado por caboclos do Ceará" Imagem que acompanha o artigo "Arte Popular" Fonte: HABITAT, 1951, p.55 


\section{A PRODUÇÃO DE LINA NA REVISTA}

A leitura cuidadosa dos objetos populares e a interpretação de seus elementos diante do desejo de construção de uma modernidade nacional esteve presente não só no discurso de Lina, mas também em sua produção publicada em Habitat. O número 01 da revista traz o artigo "Móveis novos" que mostra as cadeiras produzidas pelo Studio de Arte Palma de Lina Bo Bardi e Giancarlo Palanti. A influência direta que Lina apreende da cultura popular fica expressa nas cadeiras inspiradas nas redes dos navios "gaiola", que são "a um só tempo leito e poltrona. A aderência perfeita à forma do corpo, o movimento ondulante, fazem dela um dos mais perfeitos instrumentos de repouso." ${ }^{103}$ Nas outras cadeiras, além da inspiração nas formas, observamos também a utilização de materiais locais em sua produção, além dados modernos de simplicidade, racionalidade e funcionalidade.

O segundo número da revista conta com o texto "Um restaurante" ${ }^{104}$, de autoria da própria arquiteta, sobre seu projeto de arquitetura de interior feito para um restaurante de São Paulo em 1950. A preocupação em distanciar-se do mau gosto das pessoas enriquecidas donos deste tipo de estabelecimento e aproximar-se de um ideal de modernidade é declarado. O partido adotado foi o da simplicidade e da lógica, a escolha do mobiliário industrial e da utilização de plavinil colorido foi aliada a utilização de elementos locais, como o sisal nas cortinas e nos jogos de mesa, e uma síntese de balões de São João coloridos pintados nas paredes.

As cadeiras de Lina reaparecem na revista Habitat 05 dando continuidade à discussão sobre a questão do gosto. No artigo "Desenho Industrial"105, o texto que acompanha as imagens das cadeiras reforça a necessidade já anunciada pela arquiteta de que qualquer objeto moderno devesse ser coerente com as características de seu tempo, tanto pela estética quanto por sua funcionalidade. Mesmo os objetos utilitários como uma cadeira, bastante suscetíveis aos hábitos decorativos, não poderiam fugir a essa regra. A fotos mostram novamente produtos híbridos entre materiais e desenho modernos e materiais e referências locais, demonstrando a continuidade do esforço de inclusão de elementos locais em uma linguagem moderna de maneira adequada a seu tempo. O possível procedimento utilizado por Lina para esta tradução é enunciado na página seguinte no artigo "Dois objetos"106, que divide a seção de Desenho Industrial com o artigo homônimo.

\footnotetext{
${ }^{103}$ MÓVEIS novos. Habitat, São Paulo, no1, out-dez. 1950, p.54

104 BARDI, Lina Bo. Um restaurante. Habitat, São Paulo, no2, jan-mar. 1951, p.39

105 BARDI, Lina Bo. Desenho Industrial. Habitat, São Paulo, no5, out-dez 1951, p.62-63

106 BARDI, Lina Bo. Dois objetos. Habitat, São Paulo, nำ5, 1951, p.64
} 


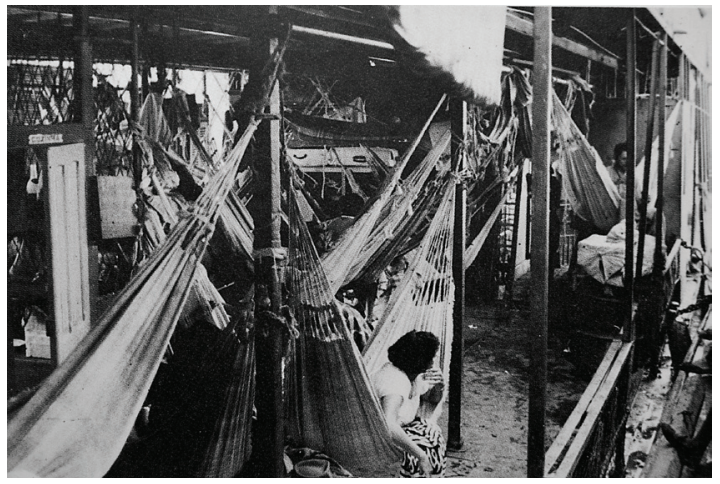

FIG.50 Redes dos "navios gaiola"

FIG.51 Cadeira tripé em madeira inspirada nas redes

Fonte: HABITAT, 1950, p.55
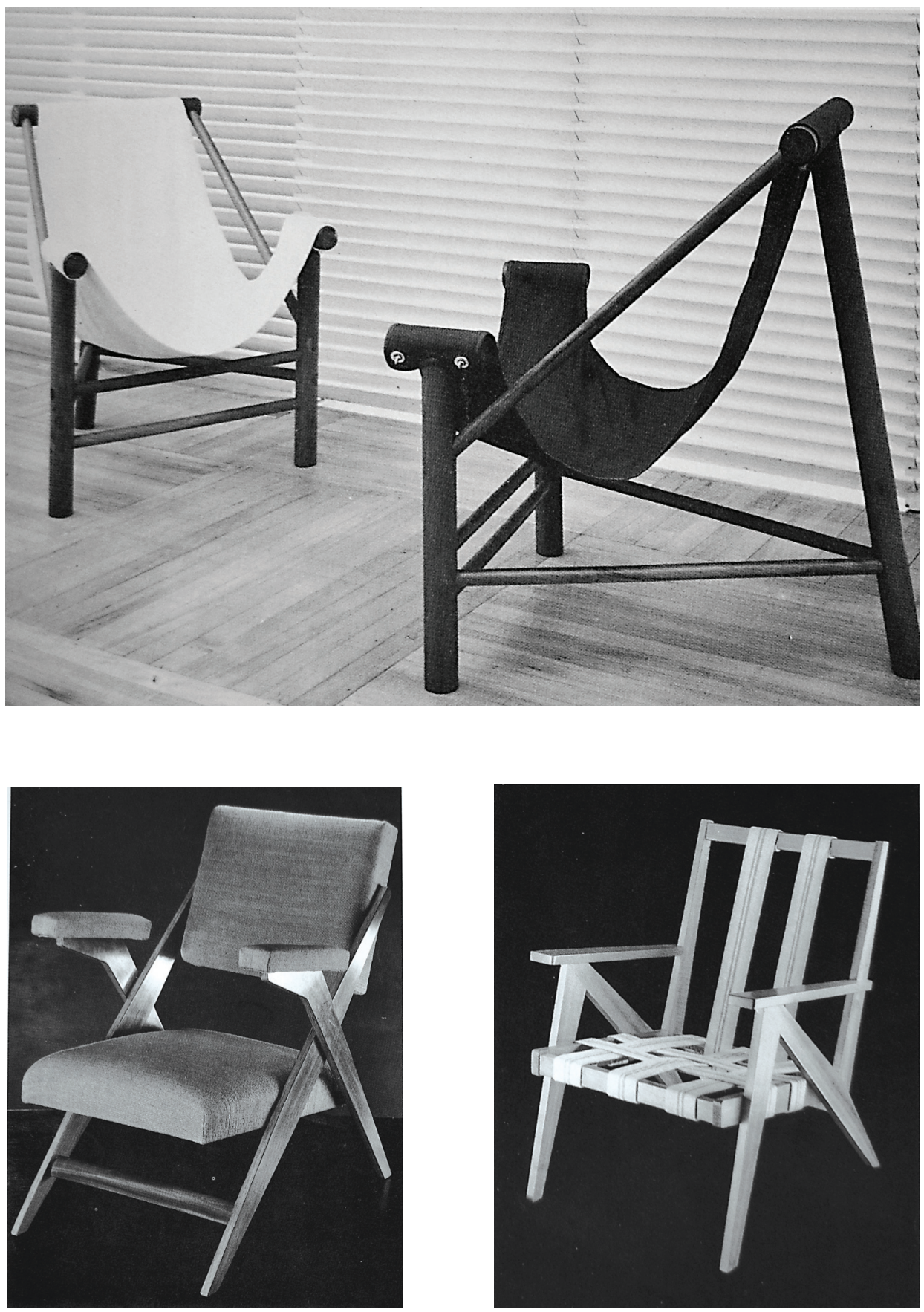

FIG.52-53 Cadeiras desenhadas e executadas no Studio Palma

Fonte: HABITAT, 1950, p.56 


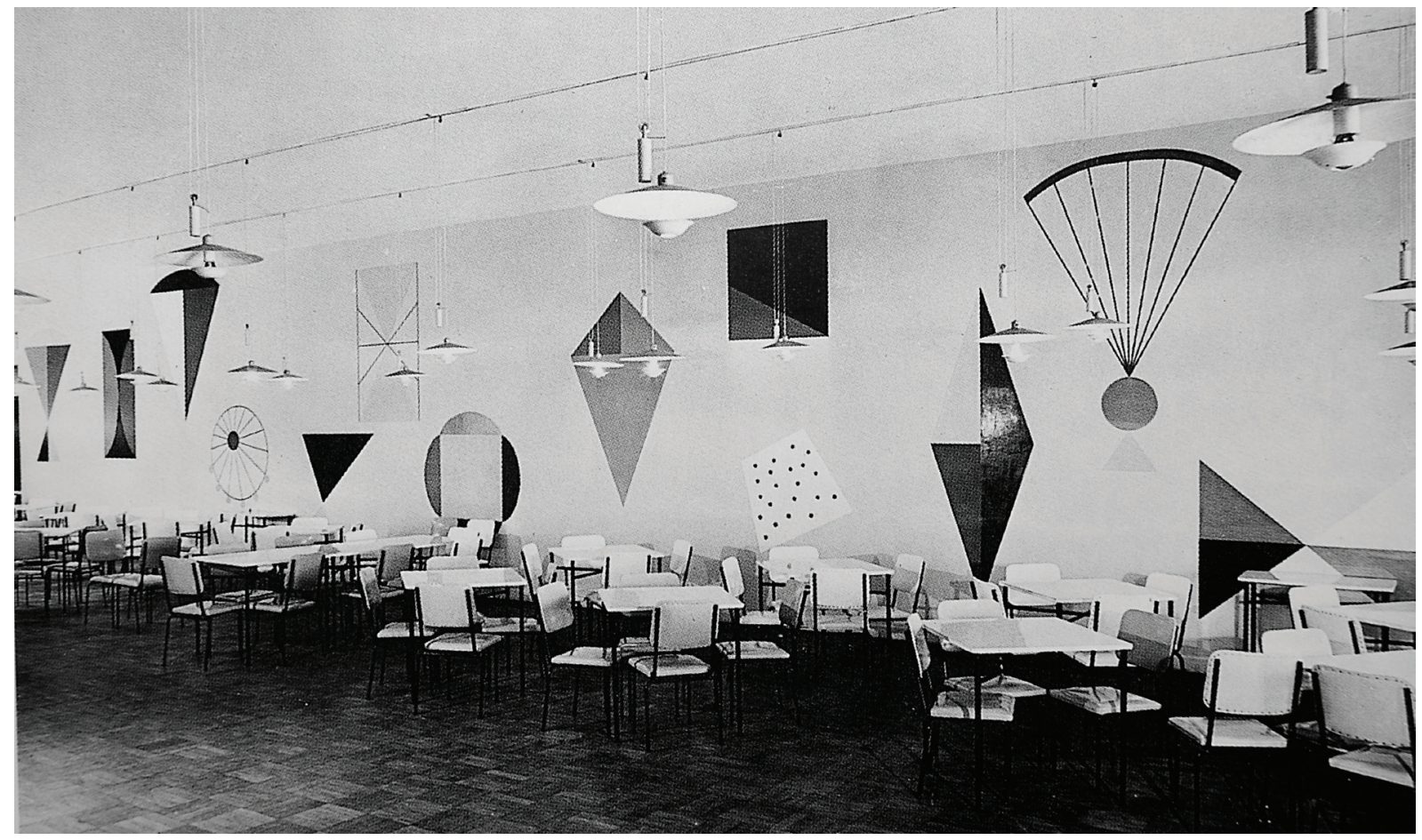

FIG.54 Projeto de interiores para um restaurante em São Paulo, Lina Bo Bardi, 1950 Fonte: HABITAT, 1951, p.30

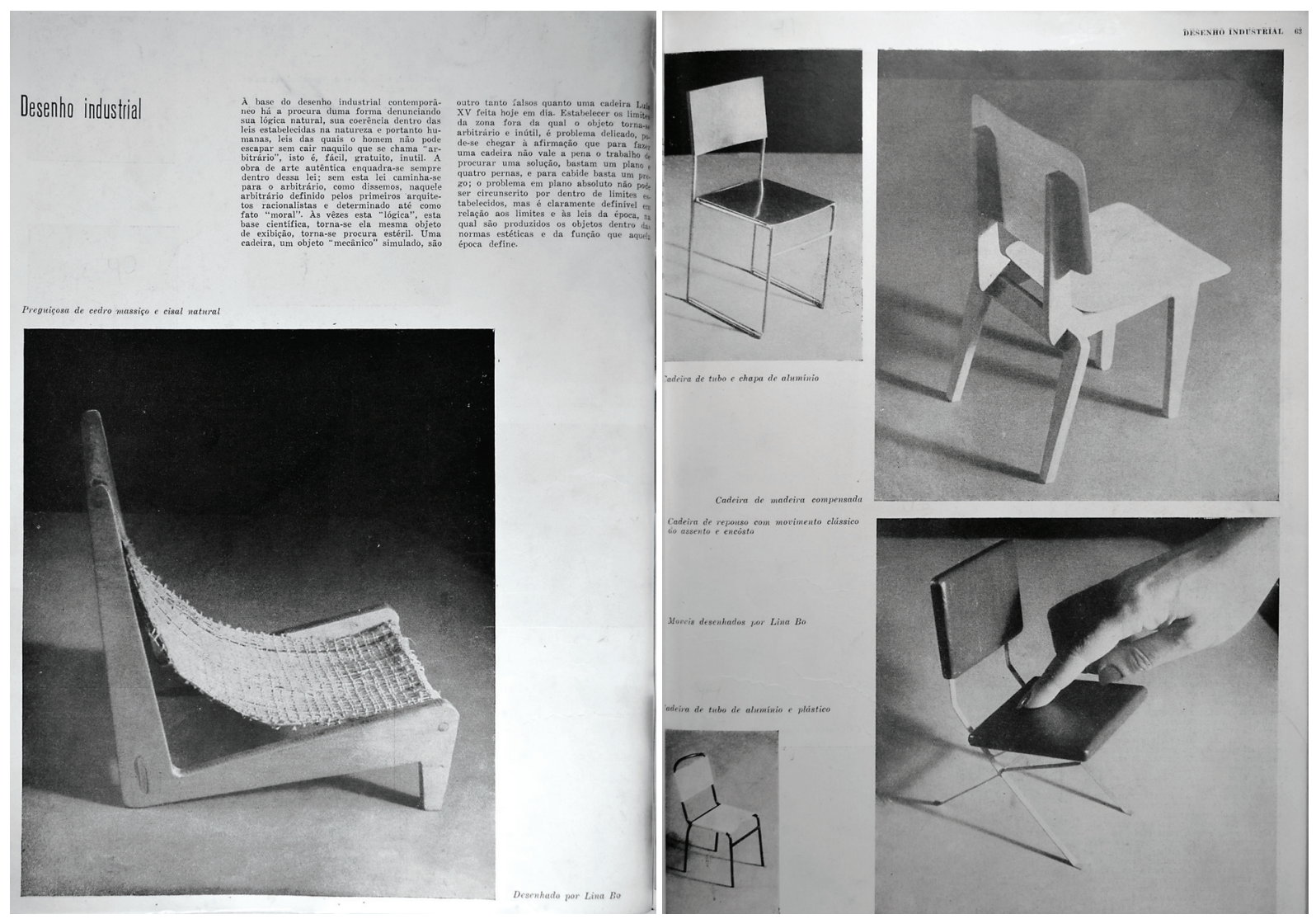




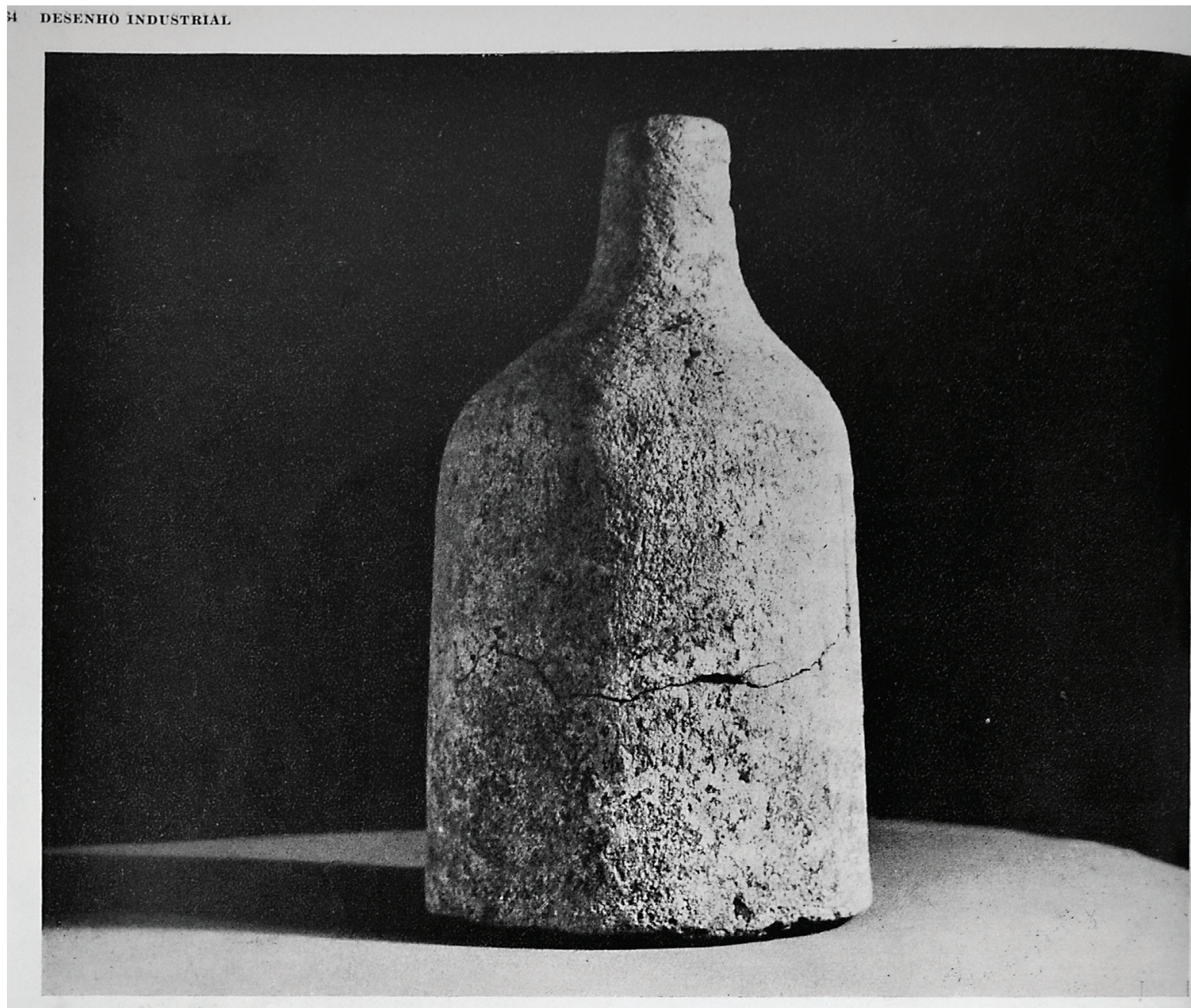

Garrafa com incrustações calcáreas

Êstes dois objetos: uma "concha" para água feita por um caboclo com casca de côco e um pauzinho de laranjeira, e a garrafa com incrustações calcáreas são objetos dos quais os arquitetos e os artistas "modernos" gostam muito, mas passam despercebidos ou quase ao observador qualquer. $O$ observador qualquer pergunta-nos - por-

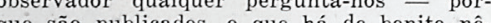
que sao púclo les. Năo há nada de bonito, o artista "moclerno" os olha porque sente instantaneamente em suas for aquela simplificação repleta de emotividade, aquela comunicação subita implicita nas coisas que trazem ainda em si a marca da natureza, que possuem ainda uma "verdade". artista assim procede quanto as descobertas dessas verdades, que mais tarde traduzira, procurando comunicalas aos poucos, lentamente, as demais pessoas, e anos e anos mais tarde o observador qualquer sustará para observar as conchas de côco e a garrafa modificada pelas incrustações calcáreas. Mas naquele momento o ar-

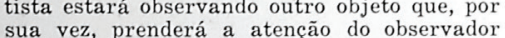
sua vez, prenderá a atenção do observador qualquer anos e anos mais tarde

Não se trata de conseguir "ver' ao mesmo tempo do artista, privilégio de aquêles modos de vê-los, revivê-los. Porisso é que zangamos com o observador qualquer que se ria da garrafa (perdoamo-lhe em seguida), mas zangamos também com um jovem arquiteto "moderno" que se ria de Borromini.

\section{Dois objetos}

Concha para água, executada por um caboe

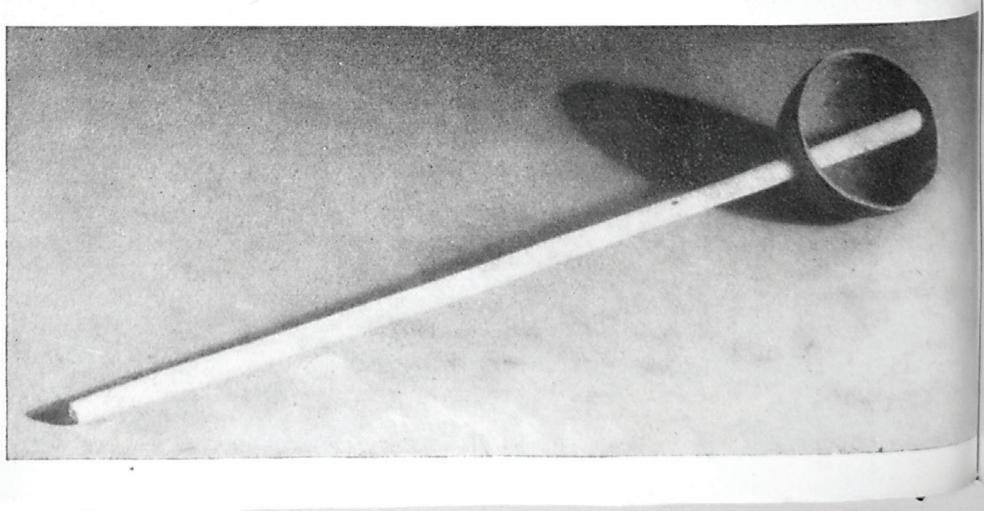


O texto acompanha imagens de dois objetos de fatura popular: uma "garrafa com incrustações calcárias" e uma " 'concha' para água feita com casca de coco e um pauzinho de laranjeira." Segundo a arquiteta, esses objetos populares de uso cotidiano, que nada têm de bonitos para os olhos do observador qualquer, carregam as características de simplicidade e a "verdade" requerida ao desenho moderno chamando a atenção para o olhar do artista, que é capaz de fazer a leitura e a posterior tradução desta "verdade" para o olhar de qualquer pessoa.

o artista "moderno" os olha porque sente instantaneamente em suas formas aquela simplificação repleta de emotividade, aquela comunicação súbita implícita nas coisas que trazem ainda em si a marca da natureza, que possuem ainda uma "verdade". 0 artista assim procede com as descobertas dessas verdades, que mais tarde traduzirá, procurando comunica-las aos poucos, lentamente, às demais pessoas, e anos e anos mais tarde o observador qualquer sustará para observar as conchas de côco (sic) e a garrafa modificada pelas incrustações calcárias. Mas naquele momento o artista estará observando outro objeto que, por sua vez, prenderá a atenção do observador qualquer anos e anos mais tarde. ${ }^{107}$

\section{ARQUITETURA POPULAR}

A questão da "verdade" na produção popular segue ao longo da Habitat não só nos objetos, mas também na arquitetura feita pelo povo. Embora nem todos os artigos da revista possuam autoria indicada, os de conteúdos sobre a arquitetura popular são atribuídos a Lina Bo Bardi ${ }^{108}$.

Essa arquitetura aparece na revista Habitat em construções feitas pelo povo em diversos lugares do país. A descrição dessas casas deixa evidente a particularidade dos locais em que estão inseridas e mostra como em cada caso houve habilidade para se extrair os recursos necessários para a sua concepção, seja da natureza ou ainda por meio da reciclagem de materiais industrializados descartados. Também se observa a relação respeitosa que o "homem do povo" preserva com o ambiente a sua volta, tudo isso dentro de um ciclo tradicional de conhecimento, passado de geração para geração seguido de seu aperfeiçoamento através da ação e da observação dos resultados. Diante destas condições, mais uma vez, são destacados os atributos comuns aos anseios da arquitetura moderna como a racionalidade, a funcionalidade e a simplicidade estética da construção.

\footnotetext{
107 BARDI, Lina Bo. Dois objetos. Habitat, São Paulo, no5, 1951, p.64

108 Conforme Stuchi (2006) essa afirmação foi feita por Flávio Motta para Campello (1997)
} 
O primeiro texto a tratar deste assunto aparece já na Habitat 01. Em "Amazonas: o povo arquiteto", Lina procura esclarecer que sociedade é qualquer agrupamento de cidadãos, por mais simples que sejam, que possuem seus próprios hábitos atrelados à tradição e que também possuem sua própria construção, nascida das necessidades do cotidiano.

Para o povo arquiteto do Amazônas (sic), construir uma moradia não é um problema tão difícil como para o morador da cidade, é um ato normal, fácil, natural, que tôda (sic) a família pode resolver por si, sem a intervenção daquele (sic) mundo de fiscais que se abate sobre (sic) a construção como moscas mutucas.

E nem a urbanística é um problema na Amazônas (sic): a bôa (sic) gente de lá possue (sic) espaçosas avenidas fluviais, ladeadas por árvores sempre limpassem seu fundo. ${ }^{109}$

No texto "Porque o povo é arquiteto?"110 as palavras "pobre" e "povo" são utilizadas de forma convenientemente intercalada, para que em alguns momentos se torne evidente a oposição pobre / rico, remetendo diretamente a oposição simplicidade / extravagância. Contudo, ambas as palavras "pobre" e "povo" se referem àquelas pessoas que, por falta de recursos financeiros, encontram os meios possíveis para suprir a necessidade da construção de seu abrigo. O povo retratado pela Habitat, ainda que por instinto e tradição, cria produtos com notável "simplicidade, racionalidade e construtura (sic) lógica."

"Os pobres são arquitetos porque não têm as idéias (sic) extravagantes dos ricos a respeito da casa." ${ }^{111}$ E por isso conseguem aplicar os princípios de racionalidade e funcionalidade de forma pura, sem a "construtura (sic) viciada de decorações."

Essa capacidade de construir a partir do conhecimento adquirido pela evolução de métodos tradicionais fica evidente na realização de processos como os registrados no artigo "Casa de 7 mil cruzeiros"112 para a construção de uma casa na periferia de São Paulo. A casa foi totalmente concebida por sua moradora, uma trabalhadora de olaria, que produziu desde os tijolos até as toalhinhas bordadas sob latas de conservas pintadas. As janelas reaproveitadas de uma obra em demolição, as tábuas dos caixotes de madeira que viraram mesa e, novamente, as latas de conserva que, pintadas para provavelmente armazenar outros alimentos, deixam claro que a falta de recursos financeiros não

\footnotetext{
109 BARDI, Lina Bo. “Amazonas: o povo arquiteto". Habitat, São Paulo, no1, out-dez 1950, p.70

110 PORQUE o povo é arquiteto? Habitat, São Paulo, no3, 1951, p.3

111 PORQUE o povo é arquiteto? Habitat, São Paulo, no3, 1951, p.3

112 CASA de 7 mil cruzeiros. Habitat, São Paulo, no, 1951, p.4
} 
significa necessariamente a falta de recursos materiais. É como se "essa pessoa do povo tivesse sido por necessidade ao mesmo tempo: arquiteto, proprietária, jardineira, pintora, e quantas outras cousas precisem para realizar uma bela casa." ${ }^{\prime 13}$

Tal fato também é comprovado na casa de José da Silva e Matto ${ }^{114}$, cujo processo construtivo foi registrado passo a passo para a revista. Sua casa foi construída no meio da floresta amazônica e José, que não dispunha de recursos financeiros, tinha em mãos os materiais existentes na floresta que aliados ao conhecimento do arquiteto sem compasso foram suficientes para que a construção da casa fosse realizada.

Como na selva o dinheiro não têm (sic) nenhum valor, ou quase nenhum, pode-se construir uma casa sem gastar um único tostão.

E ainda há quem acha que os da floresta sejam uma gente pobre. ${ }^{115}$

Neste texto é destacada ainda a importância da integração e respeito ao ambiente que o homem escolhe intervir para instalar sua casa.

José viajou bastante, mas compreendia que a selva não é de ninguém e ao mesmo tempo é de todos. (...) José fabricou sua casa sem arquiteto, sem o auxílio daqueles escritórios técnicos que só sabem encher as cidades de "finos palacetes" em estilo português e mexicano. (...) Conhecia, por tradição, a arte de construir e a sua belíssima casa ali está, firme, espaçosa e agradável

Aquele mundo exuberante que é o Amazonas tem na habitação de José um pequeno momento de ordem (sic), de carinho e de poesia humana, onde tão bem se compreende que construir é viver. ${ }^{116}$

A situação descrita sobre casa de 7 mil cruzeiros, que compartilha desse cuidado com o ambiente ao seu redor, mostra também atenção para aquilo que pudesse ser cultivado e extraído da natureza, além de legitimar a possibilidade de se reunir os conhecimentos acumulados de antepassados para suprir a necessidade básica do abrigo sem deixar de lado o cuidado com o conforto e a estética. "O povo nasce realmente com a arquitetura no sangue. Não é uma simples afirmação retórica, mas o instinto construtivo e um instinto inato."117

\footnotetext{
${ }^{113}$ CASA de 7 mil cruzeiros. Habitat, São Paulo, no3, abr-jun 1951, p.4

${ }^{114}$ CONSTRUIR é viver. Habitat, São Paulo, no7, abr-jun 1952, p.3-9

115 Texto junto a imagens no artigo CONSTRUIR é viver. Habitat, São Paulo, abr-jun no7, 1952, p.36

116 CONSTRUIR é viver. Habitat, São Paulo, no7, abr-jun 1952, p.33

117 BELÉM. Habitat, São Paulo, no9, out-nov 1952, p.47
} 


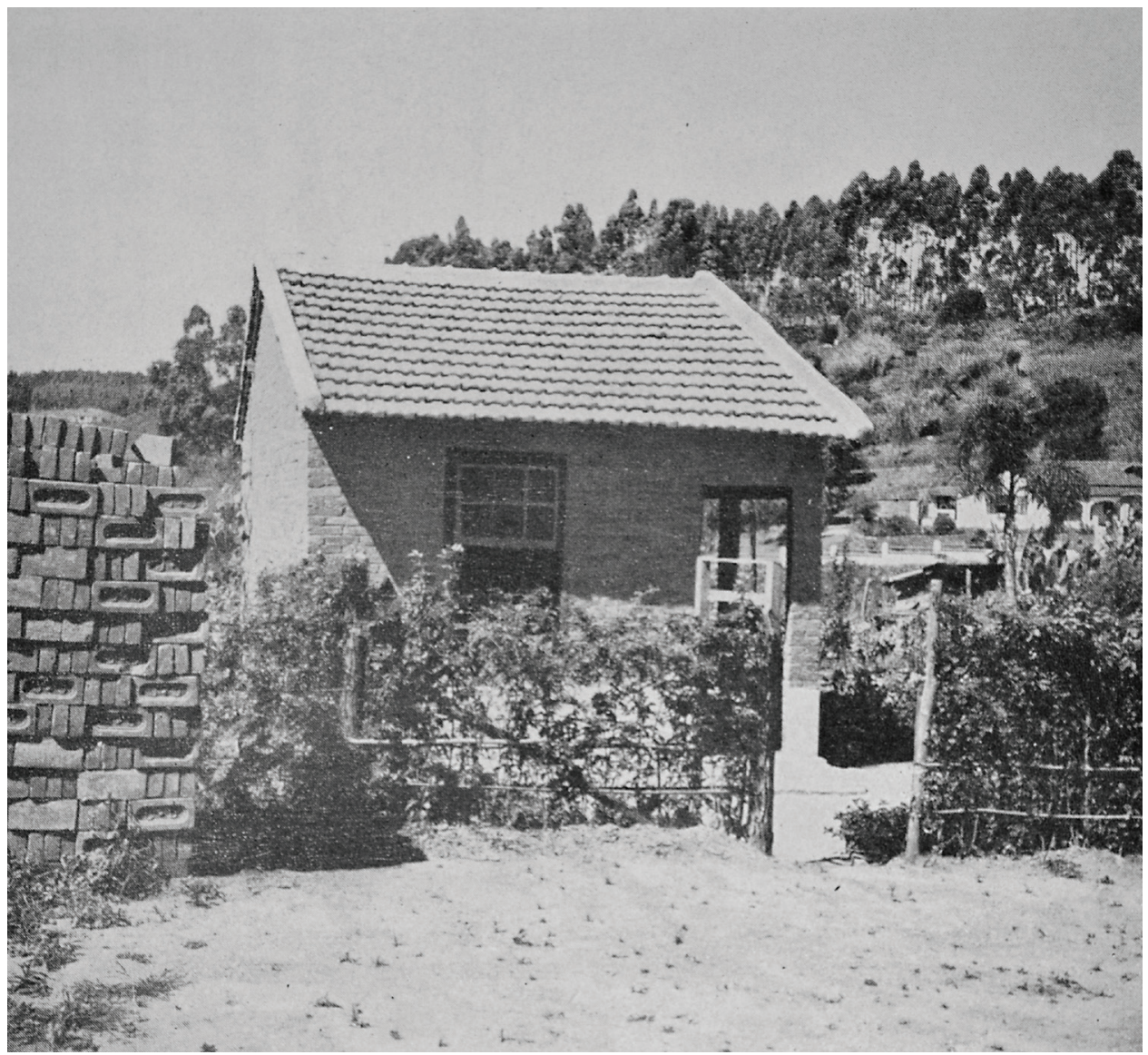

FIG.58 Vista externa da "Casa de 7 mil cruzeiros"

Nota-se a disposição cuidadosa dos tijolos ao lado da cerca

Fonte: HABITAT, 1951, p.4
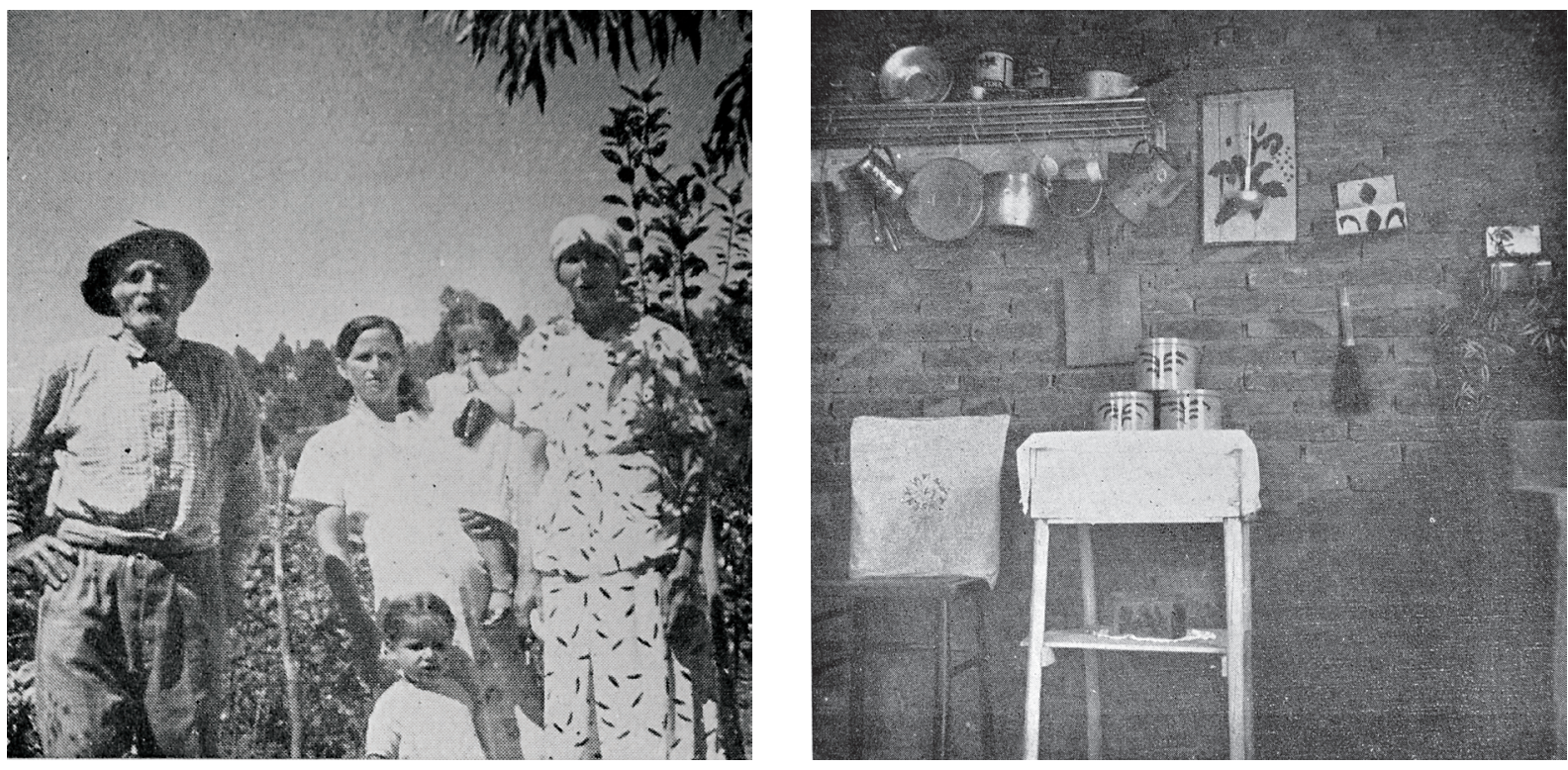

FIG.59 Família moradora da casa

FIG.60 Vista interna da "Casa de 7 mil cruzeiros"

Nota-se os utensílios domésticos feitos a partir de materiais reaproveitados

Fonte: HABITAT, 1951, p.4-5 


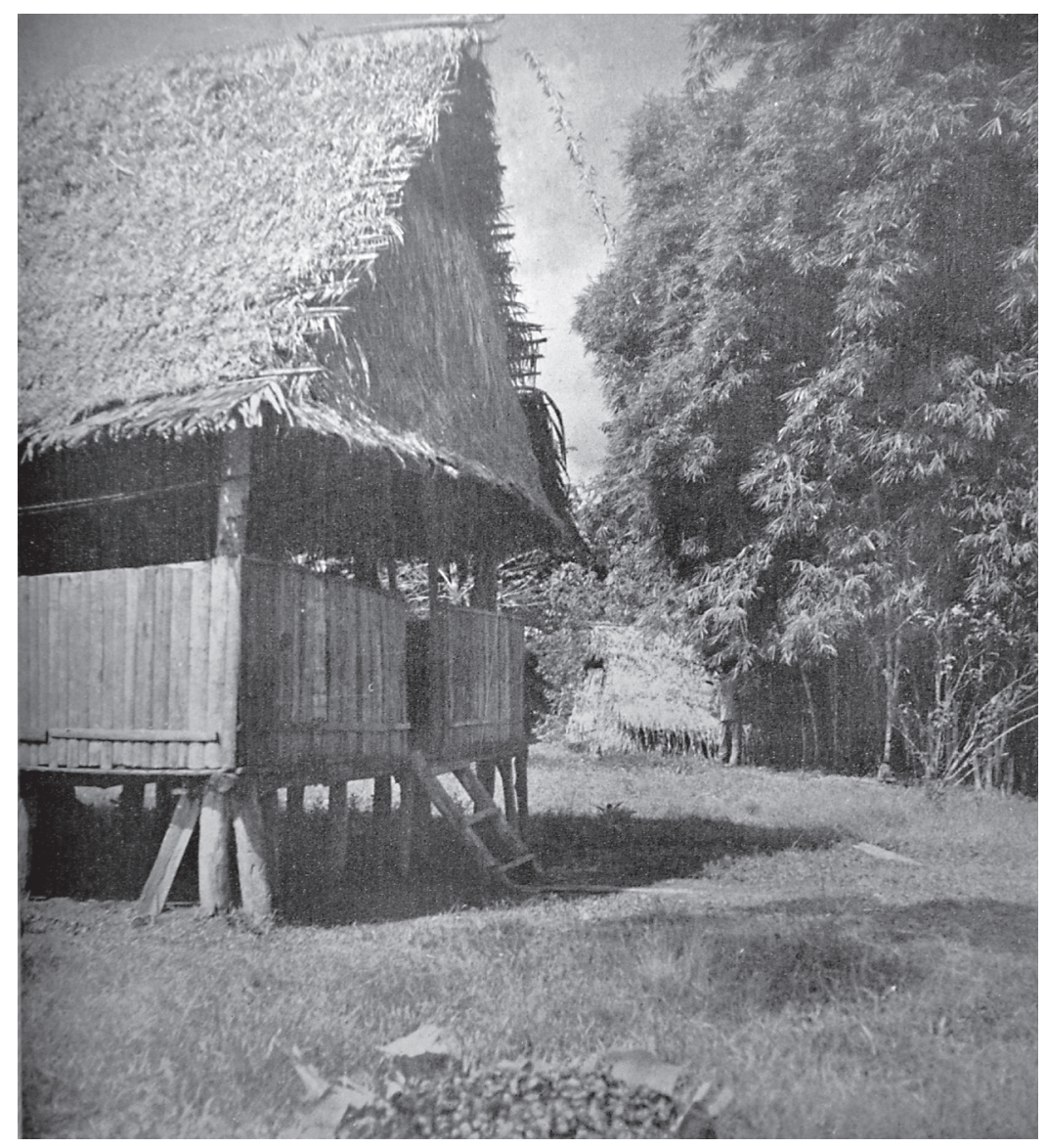

FIG.61 Vista externa da casa de José da Silva e Matto no artigo "Construir é viver" Fonte: HABITAT, 1952, p.3
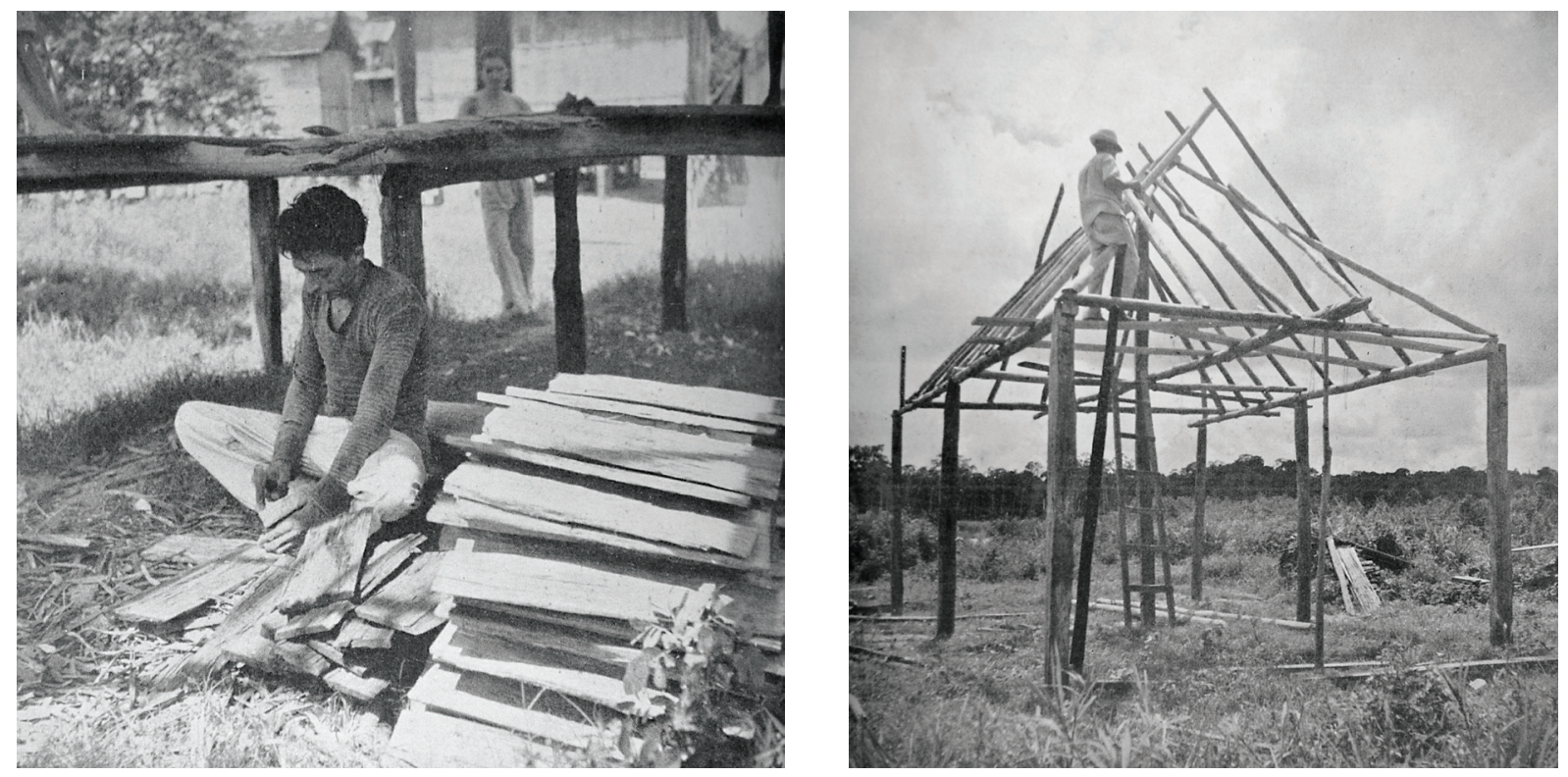

FIG.62-63 Processo construtivo da casa de José da Silva e Matto no artigo "Construir é viver" Fonte: HABITAT, 1952, p.3-5 

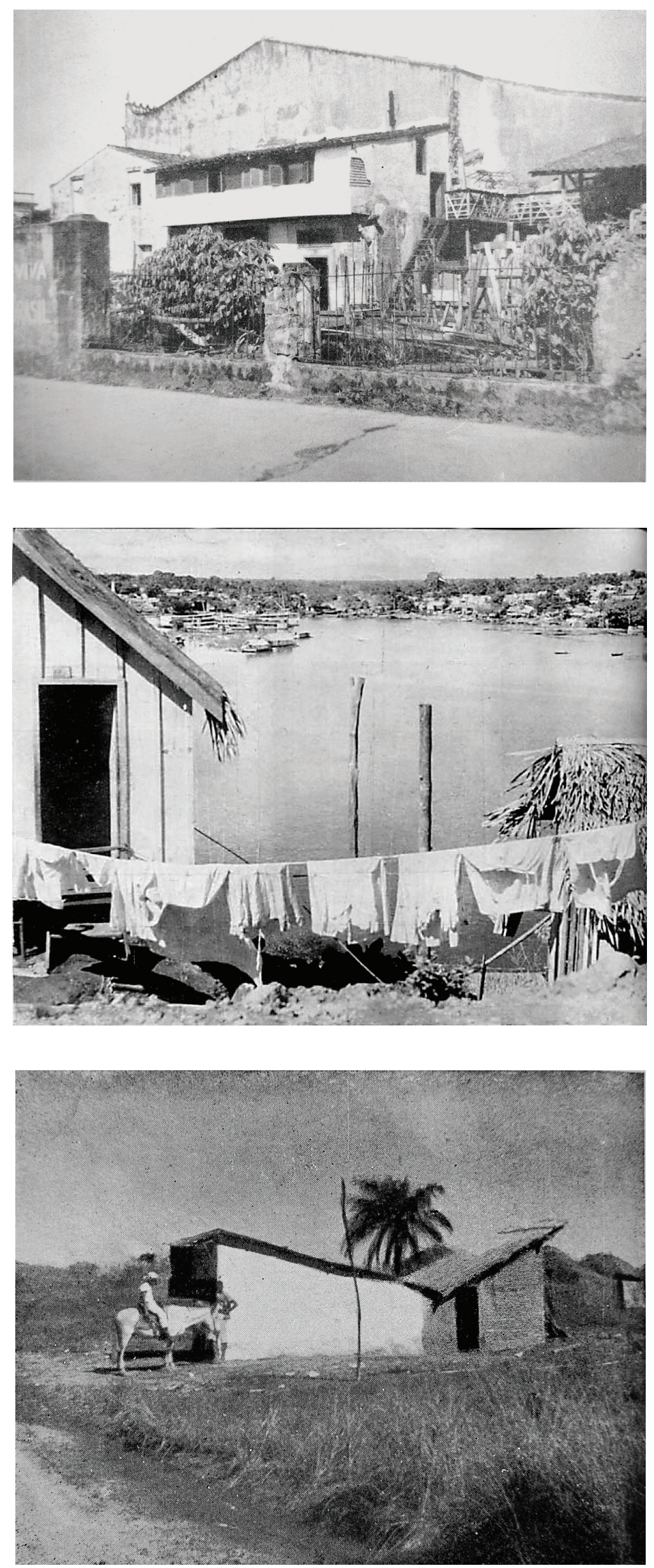

FIG.64 Casa na beira de uma estrada em Belém

Fonte: HABITAT, 1952, p.47

FIG.65 Casa na beira do rio em "Amazonas o povo arquiteto" Fonte: HABITAT, 1950, p.68

FIG.66 Casa em "O povo é arquiteto"

Fonte: HABITAT, 1953, p.52 
Outras construções como estas foram vistas durante viagens pelo país e retratadas na revista Habitat, como por exemplo a casa numa estrada de Belém, considerada como "um dos exemplos de arquitetura, incríveis por sua simplicidade e pelas soluções ousadas ou não previstas, ou ainda, realizadas com praticidade e intrepidés (sic)." 118

O sentido de instinto inato que age, observa os resultados e aos poucos se "transforma em inteligência e conhecimento dos problemas concretos", acabando por atingir as suas finalidades de "economia, propriedade dos materiais, exato emprêgo (sic) das funções, conhecimento dos resultados práticos." ${ }^{119}$

\section{A FORMULAÇÃO DE UMA DIDÁTICA}

Reconhecendo a grande complexidade cultural existente no país, a revista Habitat chega ao número 09 com a sugestão da criação de uma Enciclopédia Brasileira como forma de sistematizar as bases de uma cultura que pretenderia sua evolução a partir de fundamentos concretos tomando como base a crença de "que instaurar uma cultura nacional seja algo semelhante à construção de um grande edifício, de boa estrutura, indiscutível solidez, oportuna utilidade e estilo correto." ${ }^{120}$

Esta sugestão veio da observação sobre o fato de que naquele momento não havia um esforço para a consolidação desta cultura, ao contrário, a revista frequentemente acusava o diletantismo que reside em muitas de suas manifestações.

Neste sentido, podemos constatar, antes de mais nada, uma grave falta do sentido da medida e da proporção, e paralelamente, uma quase total incompreensão do autêntico sentido da atividade cultural e científica. (...) Em virtude disso, tudo permanece, bem ou mal, avulso no espaço, sem raízes autênticas que poderiam garantir o sentido orgânico futuro, e acaba desaparecendo em deixar traços, moda que passa, moda que surge de um entusiasmo súbito e que logo é esquecida e se dilui irremediavelmente. ${ }^{121}$

\footnotetext{
118 BELÉM. Habitat, São Paulo, no9, out-nov 1952, p.47

119 O POVO é arquiteto. Habitat, São Paulo, no10, jan-mar 1952, p.15

120 POR uma enciclopédia brasileira. Habitat, São Paulo, no9, out-nov 1952, p.1

121 POR uma enciclopédia brasileira. Habitat, São Paulo, no9, out-nov 1952, p.1
} 
Assim como os textos de abertura dos números 02 e 03 da revista, segue a crítica ao conhecimento gerado pelos intelectuais, que constantemente poderia se mostrar de restrito, superficial e por vezes equivocado.

a conversa fácil e o brilho aparente é algo que impressiona extraordináriamente (sic), aqui, inclusive os mais inteligentes e preparados; parece que a enfase (sic) categorica (sic) das afirmações as mais estapafurdias (sic) e a aparência muitas vêzes (sic) criada artificialmente por habeis (sic) propagandistas do próprio circulo (sic) de relações intimas (sic) sejam os criterios (sic) pelos quais se mede a importância e o valor das pessoas e dos acontecimentos, estranho destino esse, que pesa sôbre (sic) a nossa mentalidade.

Diante dessa situação,

A necessidade de uma tomada de consciencia (sic) da própria situação e de uma séria e vigorosa ação pedagogica (sic), que deve começar por dar uma idéia (sic) das coisas básicas, e do critério metodico (sic), já ha (sic) algum tempo que vem se fazendo sentir. ${ }^{122}$

Dentro desse processo de formação da cultura nacional ainda deveria se definir um posicionamento quanto a composição entre a aderência de referências internacionais aceitando seus preceitos, a negação completa dessas referências como forma de proteção da cultura genuinamente nacional, ou ainda a incorporação de referências internacionais acrescentando-lhes um conteúdo local.

Neste impasse, do que é preciso sair de uma maneira ou de outra, neste fermento geral, na necessária indecisão da escolha e do caminho a seguir, o que nos parece obra inicial fundamental, única capaz de conferir a indispensável unidade a uma tarefa tão difícil, é a criação de uma base informativa segura e autoravel (sic). Uma base que pudesse corresponder a uma completa e original Enciclopédia Brasileira. ${ }^{123}$

Com modestia (sic), mas com empenho total, uma tal enciclopedia (sic), como instrumento único e autorizado de informação nacional e internacional, criaria um sistema operante sôbre (sic) a consciência pública, dirigindo e orientando, além de

122 POR uma enciclopédia brasileira. Habitat, São Paulo, no9, out-nov 1952, p.2

123 POR uma enciclopédia brasileira. Habitat, São Paulo, no9, out-nov 1952, p.2 
preparar uma categoria de especialistas, aptos para contribuírem diretamente à elaboração de uma cultura. ${ }^{124}$

Ainda que não saibamos ao certo a autoria deste texto, podemos afirmar que seu raciocínio estava em completo acordo com o pensamento de Lina ao verificarmos seus trabalhos posteriores. O esforço em desvendar a gênese da cultura brasileira segue com suas pesquisas na Bahia a partir de seu deslocamento para o Nordeste em 1958. Assim como a cultura popular presente na revista Habitat, a continuidade do estudo de Lina sobre a gênese da cultura brasileira permaneceu sob um recorte específico. A coleta de objetos, as exposições e a idealização de uma escola de desenho industrial fizeram parte deste escopo e tiveram papel fundamental na consolidação deste ideal moderno fundamentado nas tradições que já vinha se desenvolvendo a partir da Itália.

A ideia da enciclopédia é análoga à “Gramatiquinha Brasileira” ${ }^{125}$ proposta por Mário de Andrade, uma referência sobre as ações e necessidades de inventariar a cultura popular brasileira, para nutrir o campo da modernidade no país: fez isso com a música e a dança, recolhendo substância rítmica, formas compositivas e conteúdos (ou temas) típicos identificados com um retrato da cultura nacional - a brasilidade.

Assim como Mário de Andrade, o interesse e o entendimento de Lina sobre a cultura popular não pretendiam atingir uma natureza acadêmica, mas sim servir como instrumento para a formação da modernidade nacional. Conforme Azevedo (1995), para Lina, a cultura possuía um caráter libertário e desse modo atingia uma dimensão política. Essa dimensão política da cultura materializou-se na produção da arquiteta através de seus textos, exposições e notadamente através das obras de arquitetura de caráter público, como veremos mais adiante.

Contudo, a experiência de Lina com as atividades no IAC possibilitou que a arquiteta também se aproximasse da universidade. Em 1955, Lina iniciou suas atividades como docente na Faculdade de Arquitetura e Urbanismo da Universidade de São Paulo com a disciplina de Composição Decorativa. Permaneceu no cargo até 1957, quando escreveu sua Contribuição Propedêutica ao ensino de Teoria da Arquitetura como tese para concorrer à cadeira de Teoria da Arquitetura.

\footnotetext{
124 POR uma enciclopédia brasileira. Habitat, São Paulo, no9, 1952, p.3

125 Estudos sobre a "Gramatiquinha Brasileira" de Mário de Andrade podem ser encontradas (entre outros) em: ALMEIDA, Aline Novais de. "Edição genética d’ A gramatiquinha da fala brasileira de Mário de Andrade". São Paulo, FFLCH, Dissertação de Mestrado, 2013

PINTO, Edith Pimentel. "A gramatiquinha de Mário de Andrade: Texto e Contexto". São Paulo: Duas Cidades; Secretaria do Estado da Cultura, 1990
} 
Esta tese, que traz recomendações sobre o ensino de arquitetura, apresenta também considerações que postulam sobre a aproximação da teoria da arquitetura à prática com completa aderência à realidade, reforçando a importância do estudo da história como parte da constituição do pensamento sobre o presente a partir do entendimento acerca da importância de se "superar a "fratura" histórica de um conflito de transição entre o "antigo" e o "moderno", procurando esclarecer e compreender a continuidade da história, e iluminando assim a mente do estudante mediante o hábito da cultura com relação à profissão, ou seja, à vida real." ${ }^{126}$ Lina pretendia, dessa maneira, provocar a ampliação do olhar para além do estudo da história e dos manuais de arquitetura e alerta aos professore que o "desenvolvimento histórico não significa, com efeito, "conciliação", e sim exame crítico profundo e sempre presente, no caso da arquitetura, indispensável para não se cair na abstração formalística." ${ }^{127}$

Por circunstâncias não conhecidas o concurso para professor da FAUUSP no qual Lina Bo Bardi apresentou sua tese foi cancelado. E por meio de um convite da Universidade da Bahia, Lina viaja para o Nordeste para ministrar palestras.

\footnotetext{
126 BARDI, Lina Bo. Contribuição propedêutica ao ensino da Teoria da Arquitetura. Tese apresentada ao Concurso da Cadeira de Teoria da Arquitetura na Faculdade de Arquitetura e Urbanismo da Universidade de São Paulo. São Paulo: Instituto Lina Bo e P. M. Bardi, 2002. Edição fac-símile do original de 1957. p.57

127 BARDI, 1957, p.69-70
} 



\subsection{OLHO SOBRE A BAHIA}

Lina chega a Bahia em um momento de grande movimentação cultural no Brasil, durante o período de abertura política entre os anos de 1945 e 1964. Sobretudo a partir de 1956, os governos de Juscelino Kubitschek (1956-1961), Jânio Quadros (1961) e João Goulart (1961-1964) adotaram como bandeira para suas campanhas o desenvolvimentismo e o nacionalismo, e com seu posicionamento populista deram margem ao crescimento de movimentos que procuravam promover melhorias estruturais dentro do contexto social.

A busca pela modernidade do país aconteceu em diversos setores e o desenvolvimento industrial e urbano, promovido sobretudo a partir do governo de Juscelino Kubitschek por meio de um desenvolvimentismo econômico, foi também acompanhado pelo desenvolvimento das artes e da arquitetura: Bossa Nova, Cinema Novo, Poesia Concreta, Brasília...

O povo emergia como importante figura social e como possível agente de transformação revolucionária desde que houvesse a conscientização de seu papel na sociedade. Neste sentido, a criação do Centro Popular de Cultura (CPC) pela União Nacional dos Estudantes (UNE) em 1961, foi uma ação que procurou aproximar o artista ao povo com livros de poesia vendidos a preços populares, com as peças teatrais encenadas em frente à fábricas, sindicatos e favelas, entre outras atividades artísticas sempre com o intuito instruir as massas. ${ }^{128}$

No Nordeste, desejava-se reverter o atraso econômico e social vivido pelos Estados que compunham esta região. Para tanto, foi criada em 1959 a Superintendência do Desenvolvimento do Nordeste

128 HOLLANDA, Heloisa B. de; GONÇALVES, Marcos A. Cultura e participação nos anos 60. São Paulo: Brasiliense, 1982., p.9-10 
(Sudene), sob a presidência de Celso Furtado, que seria responsável por prover recursos financeiros para a região. Em 1961, esse órgão dá origem ao Artesanato do Nordeste S.A. (ARTENE), cujo objetivo era agir sobre o desenvolvimento do artesanato local. Esta foi uma iniciativa vista com desconfiança por Lina Bo Bardi, que anos depois declara:

Não era uma iniciativa romântica do Nordeste, era um frio plano de financiamento sem preocupações estéticas. Um plano intermediário que desapareceria com o desenvolvimento e a elevação das rendas. $\mathrm{Na}$ "base" estava o levantamento das condições sócio-econômicas do povo Nordestino rural e semi-rural dedicado ao "artesanato": rendeiras, ceramistas, funileiros, marceneiros, tecelões, etc...

Desaparecido o corpo de sociólogos, antropólogos e economistas que se dedicavam àquela ação e pesquisa, a ARTENE subsistiu no Recife como lojinha de lembranças para turistas. ${ }^{129}$

Outras iniciativas estavam sendo empreendidas por artistas e intelectuais no Nordeste, como o Movimento de Cultura Popula (MCP) no Recife, criado em 1960, que contou com a colaboração de artistas e intelectuais como Paulo Freire, Abelardo da Hora, Francisco Brennand, Ariano Suassuna e Hermilo Borba Filho; e o Museu de Arte da Universidade Federal do Ceará (MAUC), criado em 1961, com o objetivo de levar para a universidade um conteúdo regional.

Na Bahia, em 1959, Agostinho da Silva criava o Centro de Estudos Afro-Orientais (CEAO), com o objetivo de trazer para o Brasil o estudo sobre a África, enquanto a Universidade Federal da Bahia desempenhava um importante papel no desenvolvimento cultural de diversos campos.

(...) era também o período de gestão de Edgar Santos na Universidade Federal da Bahia (UFBA) que propunha um sincretismo intelecto-cultural entre uma Bahia branca, pobre de "espírito", e uma Bahia negra, pobre de oportunidades. Uma estratégia que pôde congregar diversas fontes da cultura em torno da academia, colorindo de outros matizes a formação de jovens artistas e intelectuais. Ela incentivou a união de conteúdos da vanguarda europeia modernista aos traços fortes da cultura afro-brasileira. Foi nas aulas da universidade, nos palcos do Castro Alves e nos salões do Museu de Arte Moderna, aonde Koellreutter, Gonçalves e Bo Bardi puderam experimentar propostas artísticas humanistas e altamente criativas. Aonde construíram-se bases para uma cultura das artes nacional, democrática, radical. ${ }^{130}$

\footnotetext{
129 Lina Bo Bardi em SUZUKI, 1994, p.62 (grifo do autor)

130 GRINOVER, 2009, p.168
} 
Como testemunha desta época, Caetano Veloso em seu livro "Verdade Tropical" diz que:

Salvador vivia um período de intensa atividade cultural graças à decisão do então reitor da Universidade Federal, Dr. Edgar Santos, de somar às atividades acadêmicas das faculdades convencionais, escolas de música, dança e teatro, e de convidar os mais arrojados experimentalistas em todas essas áreas, oferecendo aos jovens da cidade um amplo repertório erudito. Ao mesmo tempo, a arquiteta italiana radicada em São Paulo Lina Bo Bardi tinha sido convidada pelo governo estadual para organizar o Museu de Arte Moderna da Bahia, onde, além do acervo crescente de obras brasileiras e estrangeiras, víamos magníficas exposições didáticas que, se fosse o caso, contavam com alguns quadros e esculturas de grandes artistas (Renoir, Degas, Van Gogh) a que a senhora Bardi tinha acesso por ser mulher do diretor do Museu de Arte de São Paulo. O Museu de Arte Moderna da Bahia funcionava no foyer, todo em mármore e vidros, do imenso Teatro Castro Alves, que tinha sido quase inteiramente destruído por um incêndio apenas um dia depois de inaugurado, poucos anos antes da criação do museu. O foyer ficara intacto, mas a sala de espetáculos tinha se transformado numa enorme caverna negra de que Lina Bardi utilizou a parte correspondente ao palco para criar um pequeno teatro de meia-arena onde, em sua colaboração com o diretor da Escola de Teatro, Eros Martim Gonçalves, montou-se a "Ópera de três tostões", de Brecht. ${ }^{131}$

\section{HISTÓRIA E PRESERVAÇÃO}

A primeira passagem de Lina por Salvador ${ }^{132}$ ocorreu em abril de 1958 para participar de um seminário na Escola de Belas Artes da Universidade da Bahia a convite da direção da escola. Em suas palestras a arquiteta procurou destacar a importância da humanização da arquitetura e utilizou como exemplo imagens da arquitetura de Antoní Gaudi, cujo contato havia se dado no ano anterior em temporada na Espanha.

Em agosto do mesmo ano, Lina retornou à Universidade da Bahia para colaborar com o professor Diógenes Rebouças na disciplina de Teoria e Filosofia da Arquitetura no curso de Arquitetura. ${ }^{133} \mathrm{Na}$ aula inaugural do curso Lina procurou esclarecer aos alunos qual seria a interpretação dada ao nome

\footnotetext{
131 VELOSO, Caetano. Verdade Tropical. São Paulo: Companhia das Letras, 1997. p.58

132 Conforme Rubino (2002, p.88), os contatos para este deslocamento já estavam sendo estabelecidos desde o período da revista Habitat

133 PEREIRA, 2008, p.67
} 
da disciplina a fim de estabelecer em que termos se dariam os estudos sobre a Teoria e Filosofia da Arquitetura. Em suas anotações para a aula, Lina diz que a teoria é a fundamentação básica para que se possa tomar decisões de projeto, por isso está totalmente vinculada à prática. De forma geral, ela define a Teoria como a prática planificada da arquitetura. Sobre a filosofia, Lina diz que "a filosofia duma época enquanto norma de vida da massa, concepção de mundo daquela época, se identifica com sua história; a filosofia duma época é então a história daquela época." ${ }^{134}$ Desse modo, a filosofia da arquitetura também poderia ser dita como a história da arquitetura. Contudo,

\begin{abstract}
Por história, esteja bem claro, não entendemos a "cristalização" da história, a história dos manuais e dos professores, mas a história em ato - a história do trabalho e da fadiga do homem. Olharemos para os diferentes períodos da história da arquitetura formulando as "perguntas" das quais as realizações dos diversos períodos arquitetônicos são as respostas. ${ }^{135}$
\end{abstract}

O desenvolvimento do pensamento da arquiteta sobre a questão da história como fato em permanente transformação, e por consequência, sobre as questões da preservação, manifestou-se logo em seguida através de publicações no jornal local.

Ainda em setembro de 1958, convidada por Odorico Tavares ${ }^{136}$, editor do jornal "Diário de Notícias de Salvador", Lina escreveu, diagramou e ilustrou a coluna dominical intitulada "Crônicas de Arte, de História, de Costumes, de Cultura da Vida". Durante os nove domingos em que a coluna esteve sob sua responsabilidade, além dos textos da própria arquiteta, a coluna contou também com a colaboração de outros artistas envolvidos com a Universidade que escreviam sobre assuntos pertinentes a cada uma de suas áreas de atuação artística. Conforme Pereira (2008), podem ser citados o maestro Hans Joachim Koellreutter, o escultor Mário Cravo, o professor Martim Gonçalves da Escola de Teatro da Bahia e o cenógrafo Gianni Ratto. ${ }^{137}$

A breve passagem de Lina pelo "Diário de Notícias" foi marcada por escritos que mantiveram o tom crítico característico das publicações ao qual participou anteriormente, além de conservar também uma temática fortemente ligada ao cotidiano. A cultura popular esteve presente não na demonstração de suas manifestações de arte, como ocorria na Habitat, mas através de sua relação com a cidade e as

\footnotetext{
134 BARDI, Lina Bo. Teoria e filosofia da arquitetura. In: RUBINO;GRINOVER, 2009, p. 83

135 BARDI, Lina Bo. Teoria e filosofia da arquitetura. In: RUBINO;GRINOVER, 2009, p. 83

136 Principal representante de Assis Chateaubriand na Bahia, e incentivador da permanência de Lina no Estado para a criação de um museu aos moldes do Museu de Arte de São Paulo, conforme Pereira (2008, p.67)

${ }_{137}$ Nota-se que alguns destes nomes já haviam aparecido anteriormente na revista Habitat no período de direção de Lina Bo Bardi. (PEREIRA, 2008, p.67)
} 
questões geradas pela tensão entre o crescimento de um ambiente urbano dominado pelos interesses da burguesia e uma história ainda em construção pelo povo que ali habitava.

Neste contexto, o tratamento dado ao crescimento urbano apareceu de forma recorrente na coluna, sobretudo nos textos que compunham a parte "Ôlho (sic) sobre a Bahia", onde Lina fez duras críticas à maneira como a especulação imobiliária e o urbanismo de prancheta podiam agir de forma decisiva, e muitas vezes, negativa na transformação das cidades. Considerando o princípio formado pela arquiteta de que o cotidiano faz parte da construção permanente da história, qualquer ruptura neste percurso poderia causar sérios danos a evolução de uma população enquanto órgão ativo de cultura.

Planificar, sanear, antes que a especulação imobiliária, fantasiada de filantropia, transforme as casas humildes, as ruas, as praças, o ambiente onde se desenvolve uma vida pobre, mas rica de fermentos vivos, de realidades pulsantes, em uma massa amorfa, mortificada e mortificante, o que obriga uma humanidade desvirilizada pela incompetência, pela subcultura, pelo desconhecimento dos valores humanos, a esquecer a si mesma, no desânimo de uma realidade fictícia, imposta por pseudos técnicos, pseudos urbanistas, pseudo arquitetos.

Arquitetos, urbanistas, precisamos defender-nos da invasão do Qualquer. Precisamos impedir que os valores da cultura sejam destruídos pela indiferença à Humanidade, à História, à Tradição. ${ }^{138}$

Para Lina Bo Bardi, o verdadeiro sentido da arquitetura neste momento seria o de se construir cidades efetivamente úteis aos homens, tarefa adequada ao arquiteto moderno. Entretanto, este arquiteto precisaria estar ciente de sua função diante da vitalidade da cidade para que não se tornasse também "um criador de edifícios e cidades abstratas, projetadas para uma humanidade que existe somente na sua fantasia, e os homens reais obrigados a habitar casas e cidades nas quais serão estrangeiros, as abandonarão ou serão transformados numa humanidade amorfa, sem desejos e sem personalidade." ${ }^{\prime 139}$

A falta de acesso aos assuntos referentes à cultura, ou ainda, a desvalorização do tema diante de outros acontecimentos cotidianos também foi apontada por Lina como mais uma das barreiras para a construção consciente das cidades. O esforço de manter o público geral a par dos acontecimentos de cultura promovido na revista Habitat, por exemplo, não se aplicava em outros veículos de imprensa, e acabava por manter a população alheia a esses fatos sob o senso da falta de discernimento crítico por parte destas pessoas. No terceiro número das Crônicas, em "Inatualidade da cultura”, Lina levanta esta

\footnotetext{
138 BARDI, Lina Bo. Olho sobre a Bahia. In: ROSSETTI, Eduardo P. Tensão moderno/popular em Lina Bo Bardi: nexos de arquitetura. Salvador, PPGAU-FAUFBA, dissertação de mestrado, 2002. p.101

139 BARDI, Lina Bo. Olho sobre a Bahia. In: PEREIRA, 2008, p.75
} 
questão a partir da tímida divulgação de um incêndio ocorrido no Convento do Carmo do Rio de Janeiro que destruiu também sua biblioteca.

Poder-se-ia objetar que falta no público a consciência crítica e a capacidade de julgamento, mas esta consciência crítica necessita ser criada e alimentada, e até que os problemas de cultura sejam relegados na terceira página e nos suplementos especiais e não entrosados no noticiário cotidiano, de público interêsse (sic), a maioria dos leitores continuará ignorando êstes (sic) problemas. ${ }^{140}$

Sua crítica também residiu no fato de que a minimização deste acontecimento não dava importância à necessidade de se estabelecer um debate sobre as ações a serem tomadas e situações como esta, aumentando a chance de ocorrerem equívocos em decisões posteriores, como o que ocorreu neste caso. Conforme a arquiteta, uma segunda nota lacônica sobre o assunto anunciaria a construção de um novo edifício com elevadores para substituir o velho edifício.

Nesse adjetivo velho, usado, ao invés de antigo, está tôda (sic) crise de nossa época: o cheiro de mofo da cultura abandonada a si mesma, do antigo não querido e não revivido mas sim mumificado e esquecido. Quem construirá o novo convento do Carmo? Quem será o arquiteto? Quando surgir a nova construção, sob a indiferença geral, o público poderá ver no lugar da antiga, uma arquitetura sem época, anônima, e ao observador saudoso do antigo edifício e consciente de uma ocasião perdida para uma construção verdadeiramente moderna, será talvez a única consolação aquilo que já havia chamado a atenção do repórter quando anunciou a nova construção ${ }^{141}$

Outro ponto desta situação é como a questão da preservação estava sendo tratada. Neste caso, a mera substituição pareceu bastar para os detentores das decisões sobre os assuntos de cultura, ainda que deixasse sem rastros uma parte da história daquele lugar. Entretanto, o oposto também era recorrente, a cristalização da história estava sendo aplicada, como diz Lina neste mesmo segundo número das Crônicas em Olho sobre a Bahia acerca do caso do Engenho São José da Vila de São Francisco, onde coube inclusive uma analogia sobre o que estava acontecendo com a cultura popular.

A conservação de um monumento antigo não significa a conservação de uma vitrina de museu, mas a integração do antigo na vida de hoje. Neste sentido, um edifício não tem que ser isolado, monumentalizado, ao contrário tem que ser humanizado. A conservação do antigo é um problema paralelo à da conservação das tradições

\footnotetext{
${ }^{140}$ BARDI, Lina Bo. Inatualidade da cultura. In: RUBINO;GRINOVER, 2009, p. 93-94

${ }^{141}$ BARDI, Lina Bo. Inatualidade da cultura. In: RUBINO;GRINOVER, 2009, p. 94
} 
populares, que não podem ser confundidas com o folclore. (...) A integração do antigo na vida de hoje e a valorização cuidada das correntes autênticamente (sic) populares, separadas do folclore barato, são os problemas fundamentais do homem moderno. ${ }^{142}$

O presente como continuidade da história e como parte da construção da memória de um povo traz a questão do restauro como prática a ser desenvolvida a partir deste olhar. Azevedo propõe-se a discutir esse tema através do desenvolvimento de três pontos: a crescente valorização do patrimônio, o aspecto cultural empreendido por Lina, e a sistematização da visão social e estética da arquiteta.

$\mathrm{O}$ ato do restauro procura evitar o caminho natural do mundo das coisas: a deterioração, a destruição. É, no entanto a manifestação da passagem do tempo, o envelhecimento que atribui às coisas tangíveis o seu caráter de testemunhas, a sua importância enquanto memória de referências culturais. ${ }^{143}$

A ideia de dar nova vida a um edifício antigo conservando a história formada ao longo de sua existência foi logo executada por Lina no processo de recuperação do conjunto do Unhão em 1959 para abrigar o Museu de Arte Popular da Bahia, ligado ao Museu de Arte Moderna da Bahia. Lina manteve de pé os antigos galpões da fábrica de rapé existentes no Solar do Unhão e preservou também um antigo guindaste como escultura, "realizando uma espécie de monumentalização da cultura do trabalho." ${ }^{144}$ Neste projeto Lina buscou preservar também uma antiga técnica artesanal de encaixe de peças em madeira presente nos carros de boi na confecção da escada helicoidal, de forma a concretizar a função do arquiteto como intérprete da cultura.

\footnotetext{
142 BARDI, Lina Bo. Olho sobre a Bahia. ROSSETTI, 2008, p.107

${ }^{143}$ AZEVEDO, 1995, p.88

${ }^{144}$ AZEVEDO, 1995, p.91
} 


\section{PRENÚNCIO DAS AÇÕES}

A conciliação necessária entre o antigo e o novo e entre as chamadas arte erudita e arte popular como forma de desenvolvimento de uma produção moderna nacional estariam vinculadas a uma atualização do pensamento sobre a cultura.

Neste sentido, voltando ao primeiro número das Crônicas, no texto "Cultura e não cultura", vemos que Lina Bo Bardi retoma a crítica à cultura burguesa que, segundo ela, a partir de uma lógica estabelecida por seus intelectuais, propõe um "diagnóstico frio sobre os problemas humanos" através do literato, acabando por se afastar das soluções práticas para os problemas dos homens, uma vez que, a despeito das particularidades de cada população, ele decide operar por meios universais.

Um criticismo cosmopolita superficial, com finalidade em si próprio, tomou o lugar da cultura útil ao homem, substituindo-a por uma pseudocultura, que faz brilhar através de uma luz refletida somente o literato erudito. A solução dos problemas reais dos diversos países foi substituída por uma panaceia universal distribuída com incredulidade e indiferença.

(...)

Entre o literato caviloso e eloquente, o crítico de arte ou poeta metafísico incompreensível, o cientista e o técnico isolado, está a massa dos homens que olha com desânimo os problemas da existência real, abandonados pela cultura. ${ }^{145}$

Essa massa, que por vezes não possuía nem a infraestrutura básica para a vida, e tampouco tinha disposição para decifrar os enigmas da arte determinados por estes literatos, ao procurar solução para seus problemas essenciais colocava em prática uma cultura genuína que se desenvolvia por meio da tradição.

Esta parte da humanidade, levada pelas necessidades a resolver por si mesmo o próprio problema existencial e não possuindo essa pseudocultura, tem a força necessária ao desenvolvimento de uma nova e verdadeira cultura.

Essa força latente existe em alto grau no Brasil, onde uma forma primordial de civilização primitiva (não no sentido de ingênua, e sim composta de elementos essenciais, reais e concretos) coincide com as formas mais avançadas do pensamento moderno. ${ }^{146}$

\footnotetext{
145 BARDI, Lina Bo. Cultura e não cultura. In: RUBINO;GRINOVER, 2009, p. 87-88

${ }^{146}$ BARDI, Lina Bo. Cultura e não cultura. In: RUBINO;GRINOVER, 2009, p. 89
} 
Como já havia sido destacado anteriormente na revista Habitat, a cultura popular aproximava-se da modernidade por sua simplicidade e racionalidade na solução de problemas práticos, criando produtos com valores estéticos e éticos de tal modo a serem utilizados como base para um posterior desenvolvimento da cultura e dos meios de produção modernos.

Assim, ao identificar a urgência de se criar condições para a preservação e o desenvolvimento dessa cultura tradicional, Lina propõe:

Salvaguardar ao máximo as forças genuínas do país procurando ao mesmo tempo estar ao corrente do desenvolvimento internacional, será a base da nova ação cultural, procurando, acima de tudo, não diminuir ou elementarizar (sic) os problemas, apresentando-os ao povo como um alimento insosso e desvitalizado, não eliminar uma linguagem que é especializada e difícil mas que existe, interpretar e avaliar estas correntes e, sobretudo, será útil lembrar as palavras de um filósofo da práxis, "não se curvem ao falar com as massas, senhores intelectuais, endireitem as costas". ${ }^{147}$

A atenção às culturas tradicionais sem perder de vista o desenvolvimento da cultura moderna engendraram a estratégia de atuação de Lina no Brasil, que passou a se definir a partir de ações pontuais anunciadas em seus textos.

No artigo "A arte industrial"148, a criação de um Museu de Artesanato e Arte Industrial aliado a uma Escola de Arte Industrial aparecem como possibilidade de fazer com que a rápida transformação do processo artesanal, sofrido durante os anos 1950, pudesse caminhar para uma evolução cultural dos meios de produção em que todos os agentes estivessem igualmente envolvidos com o trabalho.

Essa preocupação de Lina derivou de sua observação sobre uma possível confusão de termos ocorridos no momento em que a produção popular passou a contar com ações de incentivo do governo, que por sua vez, repercutiam no aumento da produção e acabavam por colocar em risco a riqueza cultural que envolviam os produtos do fazer popular. Diante disso, Lina faz um alerta sobre as definições dos termos envolvidos nesta questão:

O que é artesanato? A expressão de um tempo e de uma sociedade, um trabalhador que possui um capital mesmo modesto, que lhe permita trabalhar a matéria-prima e

\footnotetext{
147 BARDI, Lina Bo. Cultura e não cultura. In: RUBINO;GRINOVER, 2009, p. 89-90. Neste trecho, embora não tenham encontrado nenhuma referência direta, Rubino e Grinover especulam que o filósofo mencionado seria Gramsci.

148 BARDI, Lina Bo. Arte industrial. In: RUBINO;GRINOVER, 2009, p. 107
} 
vender o produto acabado, com lucro material e satisfação espiritual, sendo o objeto projetado e executado por ele mesmo. O que é artesão, hoje? É um executor, um especialista sem capital que empresta o próprio serviço a quem a ele fornece a matéria-prima, seja dono ou cliente, e recebe um salário em troca do próprio trabalho de execução. É o assim chamado proletário.

Que é a arte popular, quando verdadeira? É Arte, com A maiúsculo.

Qual seria a pergunta justa para uma válida resposta? Evidentemente a seguinte: existe uma razão eficiente que justifique as injeções oficiais a esse pseudoartesanato? Evidentemente não. Porque desse modo tira-se do artesão a razão mesma de sua existência, que dizer, a satisfação de poder criar o objeto artisticamente e ser materialmente o proprietário desse objeto e, em seguida, o seu vendedor. ${ }^{149}$

As injeções oficiais referidas por Lina tratam principalmente daquelas iniciativas que fizeram com que o artesanato nordestino fosse transformado em objeto de linha de produção para a comercialização em lojas de lembranças para turistas, como o já mencionado caso da ARTENE.

A transição para um modo de produção industrial em várias escalas acabou por intensificar a cisão entre técnico e operário executor, de maneira que,

O arquiteto que projeta um edifício não convive com o pedreiro, o carpinteiro ou o ferreiro. O desenhista de objetos domésticos, com o ceramista, o vidraceiro. O desenhista de móveis com o marceneiro. Cada um por conta própria. O desenhista técnico tem complexo de inferioridade pela ausência de competência prática. O operário executor é aviltado pela falta de satisfação ética do próprio trabalho. 150

Para a arquiteta, a ajuda oficial seria parte de uma transição necessária "enquanto o artista popular é artista pura e simplesmente e não pode sofrer influências dirigidas." Contudo, considera que o esforço para a evolução da produção deveria caminhar para a qualificação de equipes que estivessem preparadas para colaborar entre si. "Uma participação coletiva, não mais individual; o resultado técnico do artesanato dos nossos dias: a indústria."151

Desse modo, a ideia da criação do Museu é apresentada como forma de garantir a preservação da produção artesanal existente a partir da coleta ${ }^{152}$ de objetos antigos e modernos que pudessem integrar um museu vivo, "que constituísse a raiz da cultura histórico-popular do país." A escola de arte

\footnotetext{
${ }^{149}$ BARDI, Lina Bo. Arte industrial. In: RUBINO;GRINOVER, 2009, p. 107-108

150 BARDI, Lina Bo. Arte industrial. In: RUBINO;GRINOVER, 2009, p. 109

151 BARDI, Lina Bo. Arte industrial. In: RUBINO;GRINOVER, 2009, p. 110

152 Processo já visto na Itália e no Brasil como mostra o artigo Cerâmica do Nordeste.
} 
industrial teria como preocupação a questão apontada por Lina sobre a crescente cisão entre técnico e operário no processo de produção trazendo uma programação que

Permitisse o contato entre técnicos, desenhistas e executores. Que expressasse, no sentido moderno, aquilo que foi o artesanato, preparando novas levas, não para futuras utopias, mas para a realidade que existe e que todos conhecem: o arquiteto de prancha que desconhece a realidade da obra, operário que não sabe "ler" uma planta, o desenhista de móveis que projeta uma cadeira de madeira com as características do ferro, o tipógrafo que compõe mecanicamente sem conhecer as leis elementares da composição tipográfica e assim por diante. ${ }^{153}$

Em um documento escrito em $1963^{154}$, Lina define as diretrizes para a Escola que funcionaria nas dependências do conjunto do Unhão e cuja viabilidade se daria por um orçamento específico já definido, bem como um possível convênio com a SUDENE, com o Governo do Estado da Bahia e a Fundação Museu de Arte Moderna da Bahia.

A escola de arte industrial anunciada no artigo "Arte industrial" na realidade acabou sendo definida posteriormente como escola de artesanato, pois para Lina em um país jovem cuja a produção ainda permanecia tão ligada à terra, o estudo imediato do desenho industrial seria precoce e inútil pelo fato de existirem poucas indústrias nacionais ainda em fase experimental de implantação. Além disso, o estudo sobre a produção artesanal já em atividade no Nordeste deveria ser realizado para que pudesse configurar de fato a base para um desenho industrial nacional ${ }^{155}$, já que "a "produção em série", que devese (sic) hoje levar em consideração como base da arquitetura moderna, existe na própria natureza, e intuitivamente, no trabalho popular." ${ }^{156}$ Esta pesquisa sobre o artesanato, principalmente de Salvador e do Recôncavo Baiano, seria desenvolvida pelo Departamento de Pesquisa e Documentação.

O projeto para a Escola de Artesanato foi elaborado de maneira que sua estrutura de funcionamento ficasse bastante clara: informações como quantidade de alunos, processo de seleção e características espaciais para abrigar cada tipo de atividade constavam neste documento. Também estavam descritos os cursos a serem ministrados, que por sua vez, compreendiam o trabalho específico com materiais como por exemplo o ferro, o vidro, a pedra e a madeira, além de técnicas de artes como pintura,

\footnotetext{
153 BARDI, Lina Bo. Arte industrial. In: RUBINO;GRINOVER, 2009, p. 109

154 Data estimada por PEREIRA (2008,p.242)

155 BARDI, Lina Bo. Projeto da Escola de Artesanato. In: PEREIRA, 2008, p.245

${ }^{156}$ BARDI, 2002, p.28
} 
tipografia e estamparia. $\mathrm{O}$ estudo sobre a representação gráfica e a História da Arte também foram destacados.

As instalações do conjunto do Unhão não deixariam de contar com espaço para apresentação de música, dança, teatro, cinema, exposições e debates, já que além da formação técnica, a escola tinha como objetivo contribuir para a formação do pensamento crítico de sua comunidade.

A eliminação da fratura Projeto-Execução apontada por Lina com a formação de mestres de ofício iniciaria sua atuação no campo do desenho industrial, mas poderia expandir-se para uma escala maior na arquitetura. O conhecimento sobre as propriedades dos materiais e a reflexão sobre as necessidades do homem tomariam o lugar do projeto elaborado a partir dos preceitos da forma. Pretendia-se desta maneira retomar "a produção de Arte ligada à vida prática: o Artesanato transformado em Industrial Design." 157

${ }^{157}$ BARDI, Lina Bo. “Projeto da Escola de Artesanato”. In: PEREIRA, 2008, p.245 

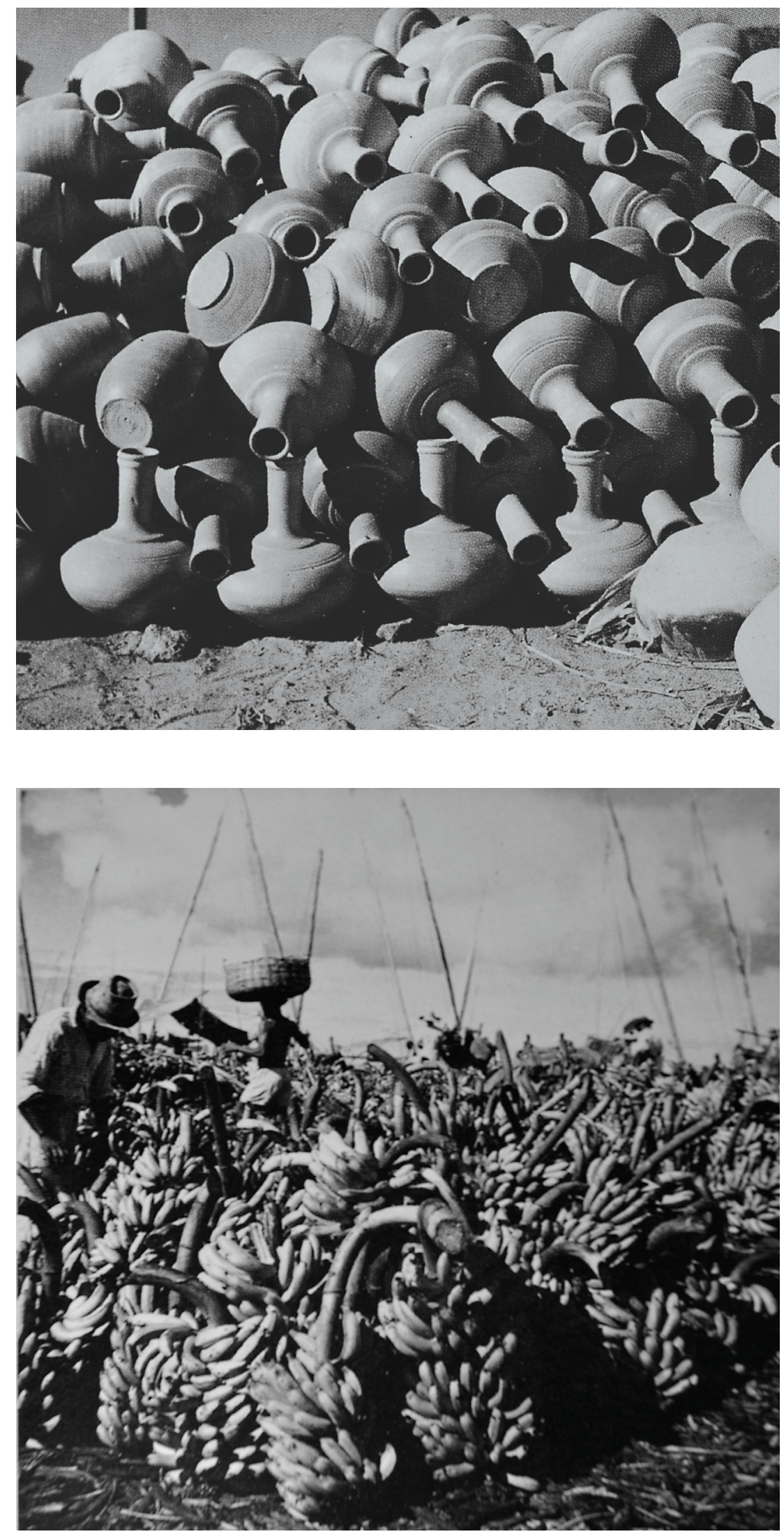

FIG.67-68 Fotos que mostram a produção em série feita pelo povo

Em sua "Contribuição Propedêutica ao Ensino da Teoria da Arquitetura Lina destaca está questão com mais imagens

Fonte: FERRAZ, 1993, p.89 
FIG.69 Página do primeiro número de "Crônicas de arte, de história, de costume, de cultura da vida" Fonte: FERRAZ, 1993, p.130

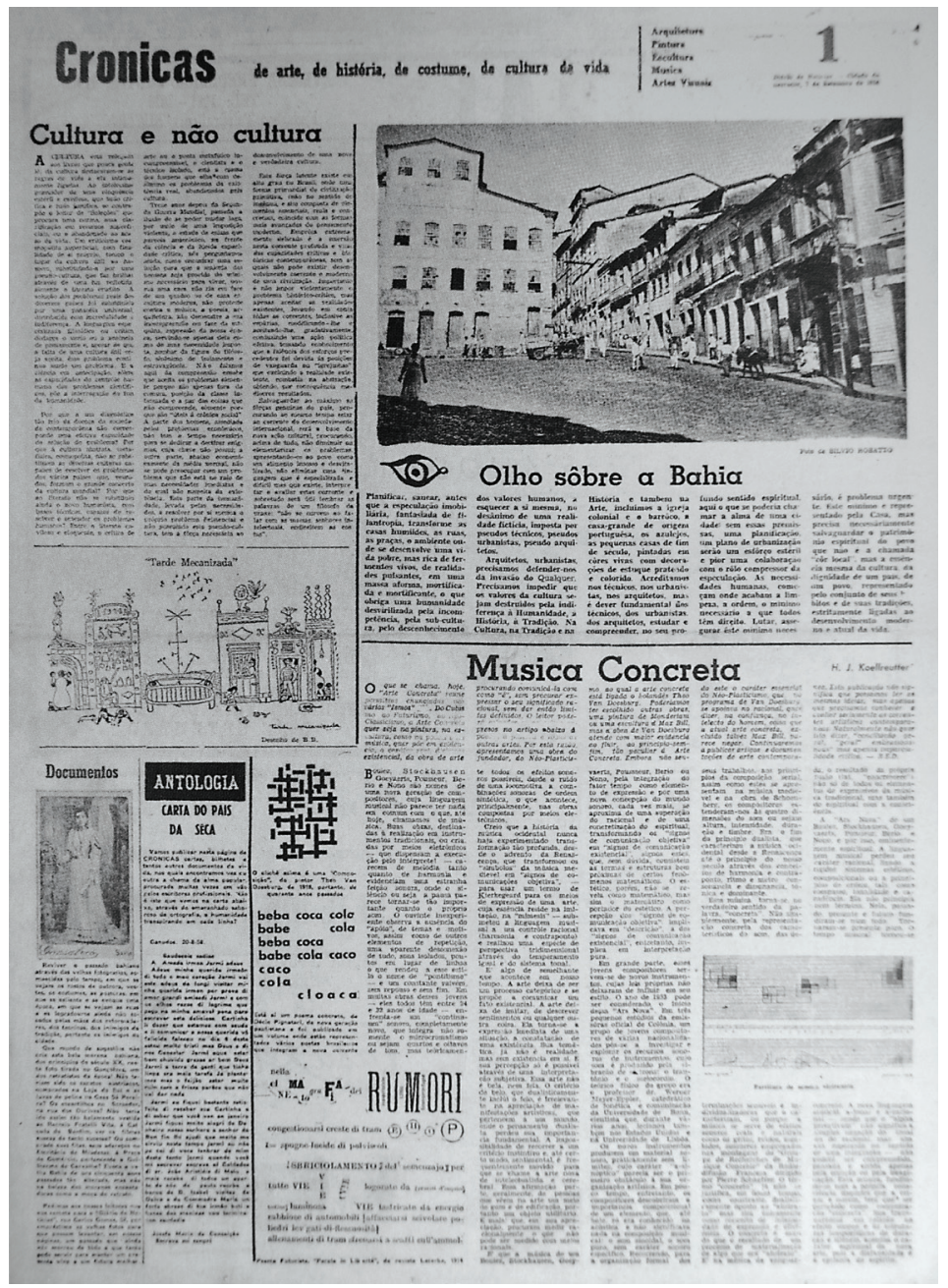



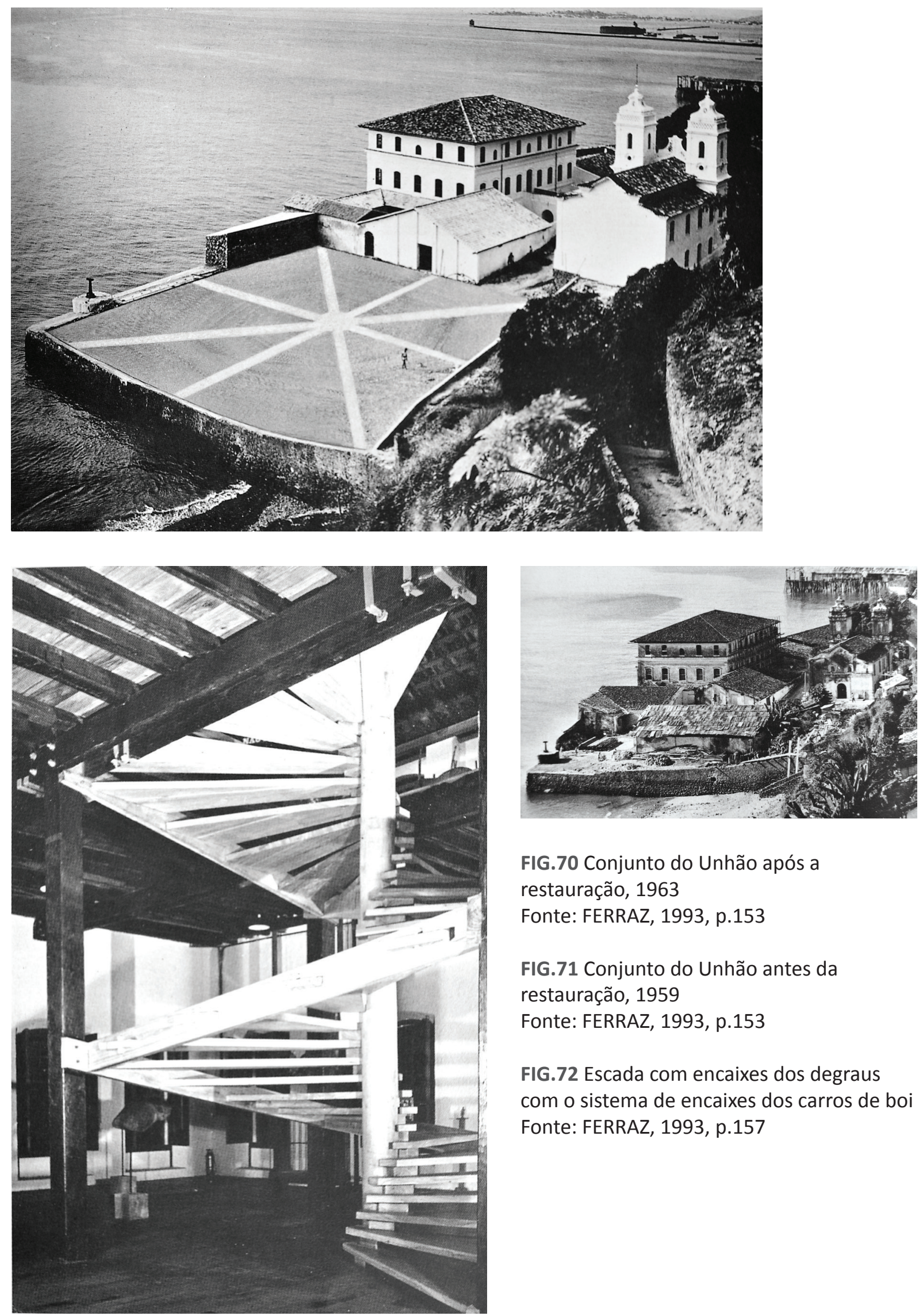

FIG.70 Conjunto do Unhão após a restauração, 1963

Fonte: FERRAZ, 1993, p.153

FIG.71 Conjunto do Unhão antes da restauração, 1959

Fonte: FERRAZ, 1993, p.153

FIG.72 Escada com encaixes dos degraus com o sistema de encaixes dos carros de boi Fonte: FERRAZ, 1993, p.157 


\section{PESQUISA SOBRE OS OBJETOS POPULARES}

O processo de interação entre os indivíduos envolvidos na produção integrou a proposta para a Escola de Artesanato idealizada por Lina e mais adiante também foi adotado pela arquiteta em seus canteiros de obras. Quanto ao trabalho de entendimento sobre a arte como uma atividade estética possível para todos, este extrapola os limites do discurso e sua materialização se inicia com grande força através da organização de exposições.

A primeira delas, realizada em 1959 através da Escola de Teatro da Universidade da Bahia foi a exposição "Bahia no Ibirapuera", no Parque do Ibirapuera em São Paulo. Montada ao lado do pavilhão da Bienal, onde naquele momento também ocorria a "V Bienal Internacional de Artes Plásticas", Lina Bo Bardi pôde dispor novamente a "arte popular" ao lado da "arte erudita". Em parceria com Martim Gonçalves, a exposição foi organizada de forma original e quase cenográfica. ${ }^{158}$

Os diversos objetos posicionados no pavilhão foram agrupados de forma a proporcionar uma leitura sobre a produção popular na Bahia que, antes de qualquer coisa, deveria ter sua imagem desvinculada da ideia de folclore. A descrição dos objetos e a ambientação criada para cada grupo fazendo referência a seu local de origem e sua utilidade tentava comunicar, através de um conceito didático de exposição, a relevância de cada uma das peças. ${ }^{159}$ A proposta de aproximar a arte da Arte tinha o intuito de evidenciar o valor estético inerente a estes objetos e o valor humano que carregavam pela riqueza constituída para além da condição precária em que foram fabricados. Aliás, Lina Bo Bardi não concordava com esta diferenciação:

\footnotetext{
Creia que para mim não existe realmente o conceito de Arte popular, em contraposição ao conceito de Arte Culta. Essa divisão é uma divisão cômoda para os críticos de arte, mas, se analisarmos a arte chamada moderna, principalmente os diversos períodos da criação artística de Picasso, por exemplo, logo concluiremos que ela contém elementos não só populares, mas, eu diria, até mesmo folclorísticos. Sim, talvez pudéssemos sintetizar tudo na célebre questão de contraste entre Forma e Conteúdo: eis aí, para mim, a divergência que pode haver entre a arte chamada popular e a chamada culta: séria, porém, difícil, insisto, delimitar as fronteiras entre uma e outra. ${ }^{160}$
}

\footnotetext{
${ }^{158}$ Característica que Lina leva adiante tanto para sua expografia quanto para sua arquitetura.

159 PEREIRA, 2008, p.104-105

160 Lina Bo Bardi em entrevista para Leo Gilson Ribeiro em 17 de dezembro de 1970. Apud RISÉRIO, Antônio. Avant-garde na Bahia. São Paulo: Instituto Lina Bo e P.M. Bardi, 1995, p. 236
} 
Consta no folheto da exposição o desejo de que se reconhecesse a poesia na efemeridade desses objetos do cotidiano, "o seu reabsorver-se no momento histórico, o seu não querer resistir ao tempo." Esse entendimento, uma vez assimilado por parte dos "instruídos", poderia trazer a libertação das "categorias", e assim não mais se teria "receio de reconhecer o valor estético numa flor de papel ou num objeto fabricado com lata de querosene." ${ }^{\prime 161}$ Então, a reivindicação sobre o direito ao exercício estético da arte atrelada à vida do homem foi elaborada.

Saímos da Antropologia Cultural e não da Arte. A exposição, com seu chão de folhas secas, seus grandes Orixás, suas colchas de retalhos, seus objetos cotidianos, comunicava junto à grande documentação fotográfica de Pierre Verger, Gautherot, Silvio Robatto e Enneas Mello, toda a violência poética de um mundo ainda intacto. ${ }^{162}$

A tentativa de aproximação do público geral com a chamada arte erudita foi realizada por Lina desde o período em que estava envolvida com as atividades desenvolvidas no Museu de Arte de São Paulo. A ideia da formação de um público para os museus foi levada para o Museu de Arte Moderna da Bahia (MAMB), cuja direção ficou sob responsabilidade da arquiteta de 1960 a 1963.

Funcionando inicialmente no foyer do Teatro Castro Alves, o museu contou com exposições de pintura, desenho, escultura, fotografia, gravura, entre outras expressões artísticas dispostas sempre de forma didática procurando constituir uma relação de proximidade entre o espectador comum e a obra de arte. ${ }^{163}$

Ao utilizar-se das hastes de aço fincadas sobre bases de concreto para expor pinturas suspensas no ar, ao eliminar sempre que possível as molduras dos quadros, ao colocar as bailarinas de Degas dançando no espaço à altura do olhar do espectador e ao se negar a usar a crítica convencional para fazer o visitante entender a obra exposta, não é outra a intenção de Lina senão a de tornar as visitas às exposições uma experiência particular de cada um com a obra de arte. ${ }^{164}$

O rompimento com a maneira tradicional de expor e o caráter didático das mostras possibilitava o encontro entre todos os tipos de público e as mais diversas manifestações artísticas, reforçando a possibilidade do entendimento da arte como uma atitude estética que poderia ser tomada por

\footnotetext{
161 Trecho do texto do catálogo da Exposição Bahia, escrito por Lina Bo Bardi e Martim Gonçalves. In: FERRAZ, 1993, p.134

162 Lina Bo Bardi sobre a exposição “Bahia no Ibirapuera” In: SUZUKI, M. (Coord.). Tempos de Grossura: o Design no Impasse. São Paulo: Instituto Lina Bo e P. M. Bardi, 1994

163 PEREIRA, 2008

164 PEREIRA, 2008, p.128
} 
qualquer um e cuja diferenciação dos produtos residia apenas nas condições ambientais em que o artista estava inserido. Conforme Lina coloca no folheto de inauguração do MAMB, "uma época nova já começou e quem não chega a compreender sua necessidade lúcida e rigorosa, melancólica sem pieguice, profundamente poética, corre o perigo de ficar de fora." ${ }^{165}$

Com parceria da Universidade da Bahia, sobretudo com a Escola de Teatro, e toda criatividade capaz de superar a falta de estrutura financeira do museu, além das exposições, o foyer do TCA também abrigou cursos de expressão artística para crianças e jovens de Salvador. ${ }^{166}$ Mais uma vez, o caráter didático do museu prevaleceu favorecendo a diversidade.

A convergência entre diferentes formas de arte pretendiam também manter vivo o debate sobre o encaminhamento futuro da cultura no país e a questão da possível associação entre artesanato e indústria defendida pela arquiteta. Sob essa ótica, entre as exposições presentes no foyer do TCA podemos citar a mostra das cerâmicas de Francisco Brennand. No texto para o catálogo da exposição das cerâmicas do artista, Lina expõe sua preocupação sobre o momento de definição dos rumos da cultura brasileira e classifica dois possíveis grupos existentes naquele momento:

O Brasil, hoje, está dividido em dois: o dos que querem estar a par, dos que olham constantemente para fora, procurando captar as últimas novidades para jogá-las, revestidas de uma apressada camada nacional, no mercado da cultura, e o dos que olham dentro de si e à volta procurando fatigadamente, nas poucas heranças duma terra nova e apaixonadamente amada, as raízes duma cultura ainda informe para construí-la com uma seriedade que não admite sorrisos. Procura fatigada no emaranhado de heranças esnobemente desprezados por uma crítica improvisada que as define drasticamente como regionalismo e folklore. ${ }^{167}$

Para o primeiro grupo descrito e para aqueles que não tinham noção da complexidade da formação da sociedade contemporânea e dos modernos meios de produção industrial restaria um entendimento equivocado sobre a relação entre artesanato e indústria, promovendo assim as associações: "artesanato-antigo, indústria-moderna: artesanato-inferior, indústria-superior."168 Quando na realidade, segundo a arquiteta, após a superação de um entusiasmo pela máquina em detrimento da visão sobre o artesanato no início do século XX, o modo de produção moderno operaria de uma maneira integrada.

\footnotetext{
165 Folheto de inauguração do MAMB. In: FERRAZ, 1993, p. 139

166 PEREIRA, 2008, p.157-158

167 Catálogo da exposição “Brennand cerâmica”. In: RUBINO;GRINOVER, 2009, p. 114

${ }^{168}$ Catálogo da exposição "Brennand cerâmica”. In: RUBINO;GRINOVER, 2009, p. 114 (grifo do autor)
} 
Na máquina que produz o objeto padrão, pensado e desenhado num sentido de artesanato-industrial, está a verdadeira síntese da arte aplicada moderna, o seu ponto final. ${ }^{169}$

A cerâmica de Francisco Brennand estaria enquadrada no mundo da procura, ainda não atrelado à indústria, mas consciente sobre a importância da simplificação aristocrática e popular ao inserir sua técnica no universo dos produtos utilitários, como pratos e placas conforme é mencionado no catálogo.

A ligação de Brennand com a indústria não o levou ainda à procura de formas, à transferência de sua sensibilidade aristocrática e camponesa na produção do objeto que acompanha o homem na vida de cada dia, como as grandes civilizações orientais fizeram. Mas Brennand chegará a isso, é um processo fatal. ${ }^{170}$

Ainda com o espírito da busca pela "verdadeira" arte do homem e seus produtos do cotidiano, o conjunto do Unhão é inaugurado para abrigar as atividades do Museu de Arte Popular da Bahia em 1963 com a "Exposição Nordeste". Tratava-se de uma mostra de objetos coletados tanto por Lina em suas viagens pelo Recôncavo baiano, quanto por outros artistas em diversas partes do Nordeste como no Ceará e em Pernambuco. ${ }^{171}$

A arquiteta considera os objetos produzidos no Nordeste como fatos populares, elementos que são suportes para uma existência, para uma vida que se desenvolve sob condições adversas. Não são obras de arte, os objetos não são produzidos nunca como obras de exceção, mesmo no caso dos ex-votos que, como afirma Lina, são sempre produtos para atender às necessidades de uma existência humana. ${ }^{172}$

A Civilização do Nordeste ${ }^{173}$ apresentada nesta exposição trouxe a produção de objetos utilitários criados para todos os níveis de necessidade a partir daquilo que já havia sido descartado pela sociedade industrial. A partir do "lixo", onde "cada objeto risca o limite do "nada", da miséria. Esse limite e a

\footnotetext{
${ }^{169}$ Catálogo da exposição “Brennand cerâmica”. In: RUBINO;GRINOVER, 2009, p. 115 (grifo do autor)

170 Catálogo da exposição Brennand cerâmica. In: RUBINO;GRINOVER, 2009, p. 115

171 BARDI, Lina Bo. Cinco anos entre os brancos. In: RUBINO; GRINOVER, 2009, p. 135

172 PEREIRA, 2007, p.196

173 "Civilização. Procurando tirar da palavra o sentido áulico-retórico que a acompanha. Civilização é o aspecto prático da cultura, é a vida dos homens em todos os instantes." Trecho do texto do catálogo da Exposição Nordeste, escrito por Lina Bo Bardi. In: FERRAZ, 1993, p.158
} 
contínua e martelada presença do "útil" e "necessário" é que constituem o valor desta produção, sua poética das coisas humanas não gratuitas, não criadas pela mera fantasia." ${ }^{174}$

Mais uma vez é colocada em evidência a constituição de uma arte derivada da necessidade de solucionar os problemas reais. "Arte popular é o que mais longe está daquilo que se costuma chamar de Arte pela Arte" ${ }^{\prime 175}$, reforçando a inadequação do enquadramento destes objetos ao que seria o folklore que, por sua vez, foi definido por Lina como "uma herança estática e regressiva, cujo aspecto é amparado paternalisticamente pelos responsáveis da cultura."

Estabelece-se assim a "acusação de um mundo que não quer renunciar à condição humana apesar do esquecimento e da indiferença" que se encontram em "um esforço desesperado de cultura." ${ }^{176} \mathrm{O}$ caráter político da atuação de Lina manifestou-se no tom de denúncia sobre o real significado dos produtos da cultura popular.

Lina certamente deseja despir as manifestações populares de toda aura sentimental que as distancia de uma efetiva práxis social e da possibilidade de inseri-las nas relações de produção e de consumo. Não se trata de comercializá-las como fetiche, como souvenir de um tempo e lugar distantes ou como singularidades exóticas de uma pseudo prática artesanal, mas de extrair das suas soluções a inventividade, para ampliar o repertório da produção industrial, agora nutrida do saber regional. ${ }^{177}$

\footnotetext{
174 Trecho do texto do catálogo da Exposição Nordeste, escrito por Lina Bo Bardi. FERRAZ, 1993, p.158

175 BARDI, Lina Bo. Arte popular e pré-artesanto nordestino. In: SUZUKI, 1994, p.25

176 Trecho do texto do catálogo da Exposição Nordeste, escrito por Lina Bo Bardi. In: FERRAZ, 1993, p.158

177 JORGE, Luís Antônio. O espaço seco - imaginário e poéticas da arquitetura moderna na América. São Paulo, FAUUSP, Tese de doutorado, 1999, p.95
} 

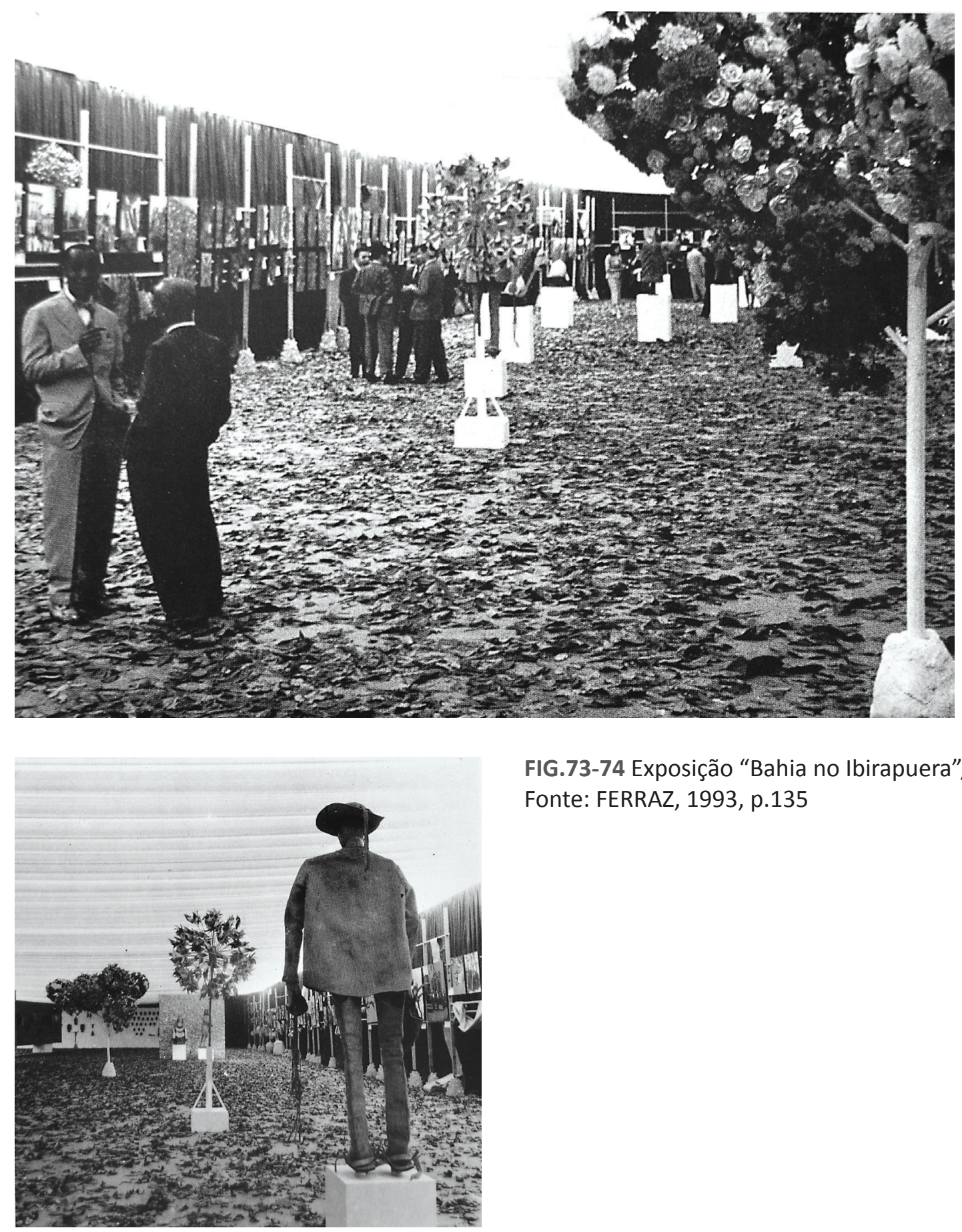

FIG.73-74 Exposição "Bahia no Ibirapuera”, 1959 Fonte: FERRAZ, 1993, p.135

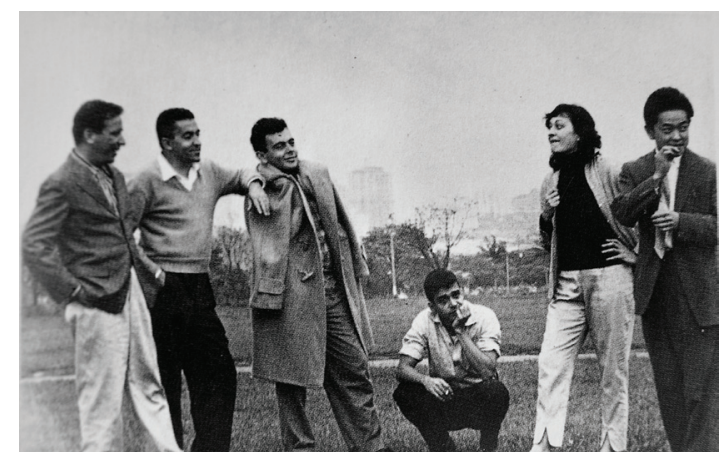

FIG.75 Lina Bo Bardi com Martim Gonçalves, Vivaldo Costa Lima, Glauber Rocha e Luis Hosska para a montagem da exposição "Bahia" no Ibirapuera Fonte: FERRAZ, 1993, p.134 
Exposições no foyer do Teatro Castro Alves

FIG.76 Exposição “Carrancas do São Francisco" Fonte: FERRAZ, 1993, p.140

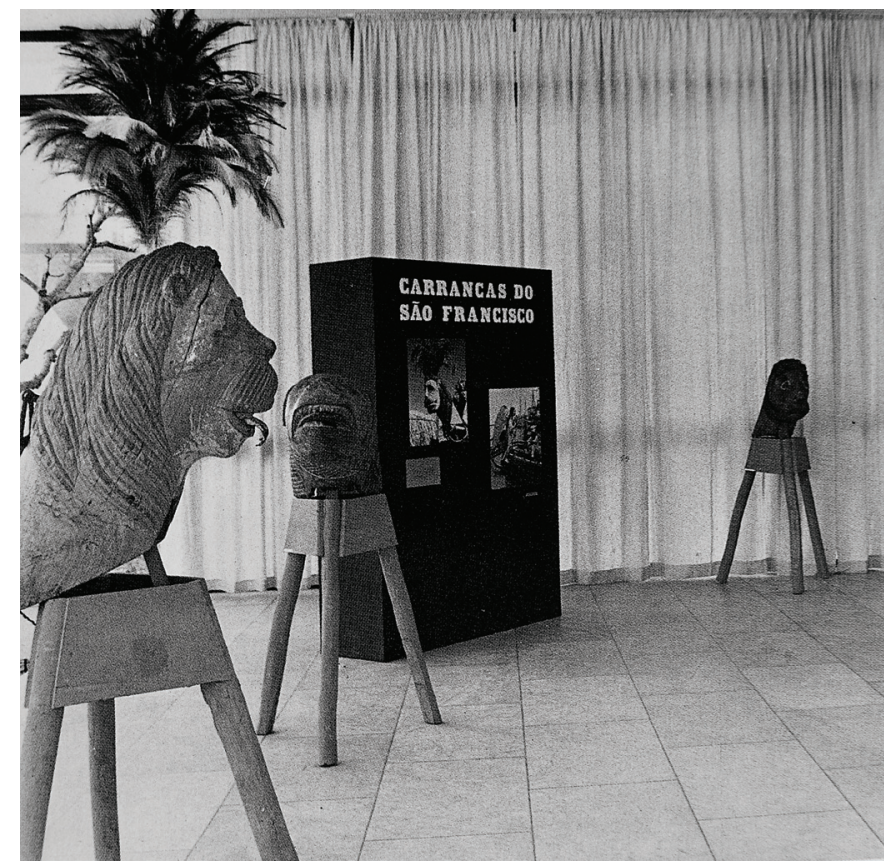

FIG.77 Exposição de cristais gigantes "Formas Naturais" Fonte: FERRAZ, 1993, p.138
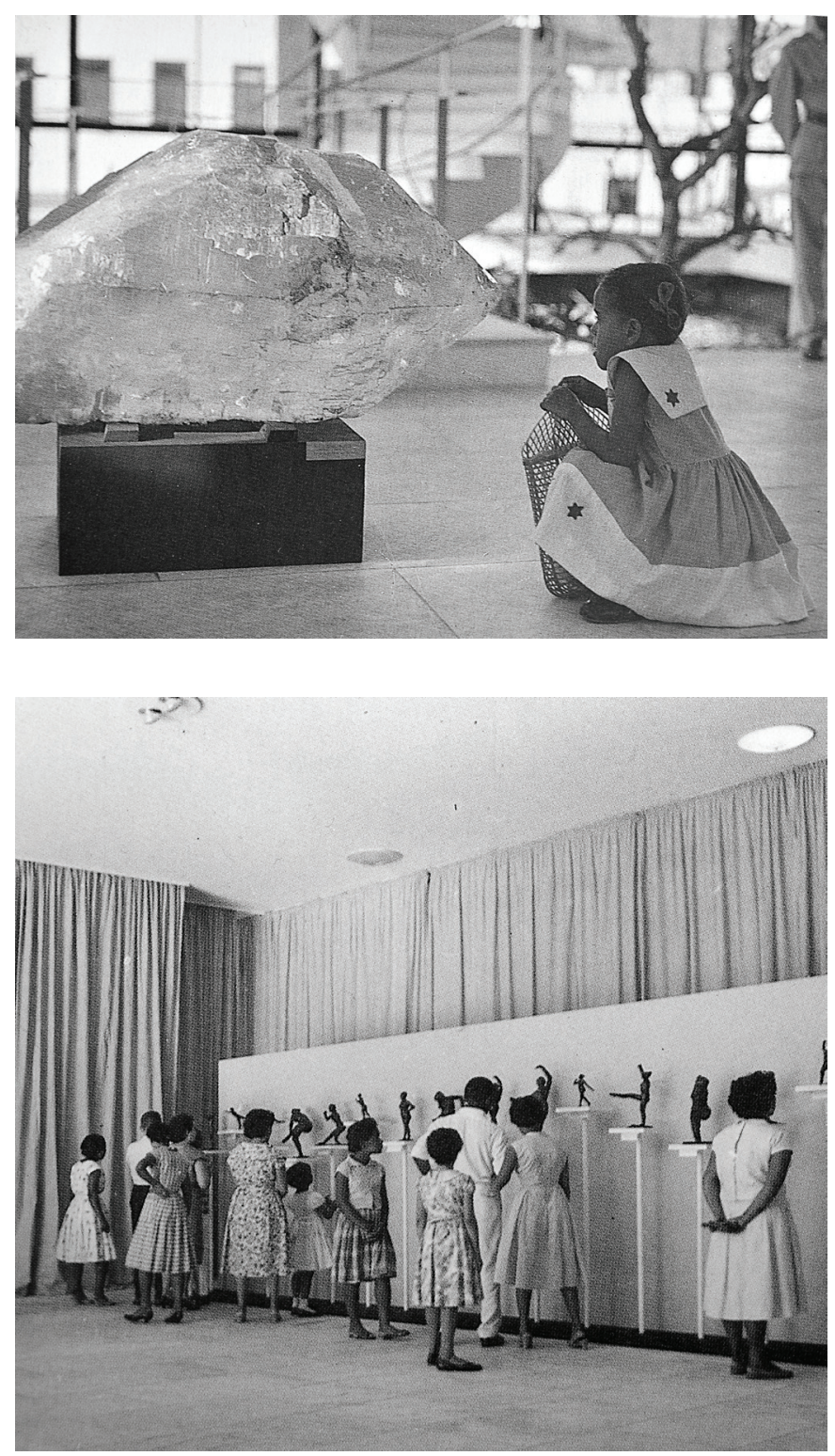

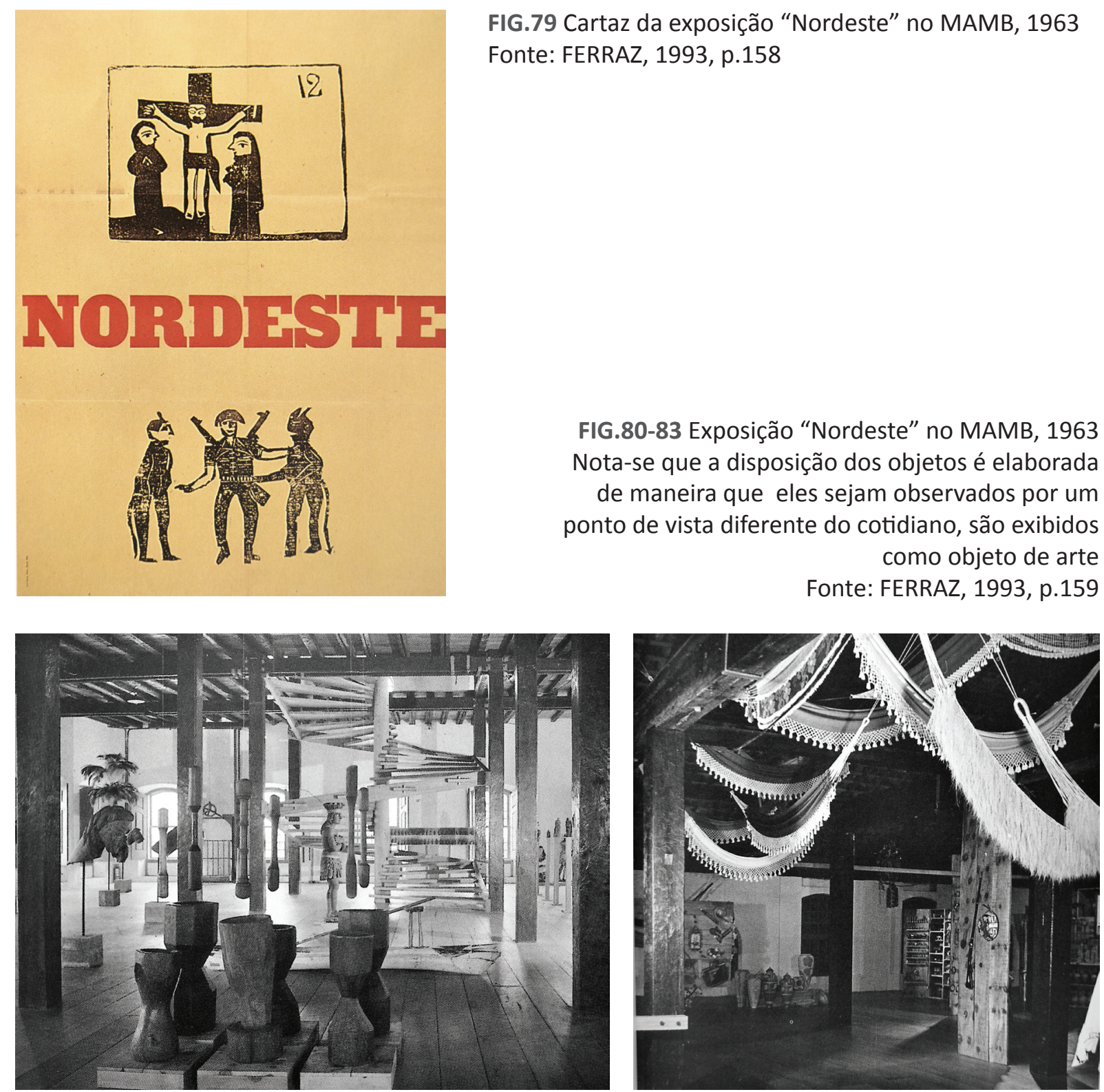

FIG.80-83 Exposição “Nordeste" no MAMB, 1963 Nota-se que a disposição dos objetos é elaborada de maneira que eles sejam observados por um ponto de vista diferente do cotidiano, são exibidos como objeto de arte Fonte: FERRAZ, 1993, p.159
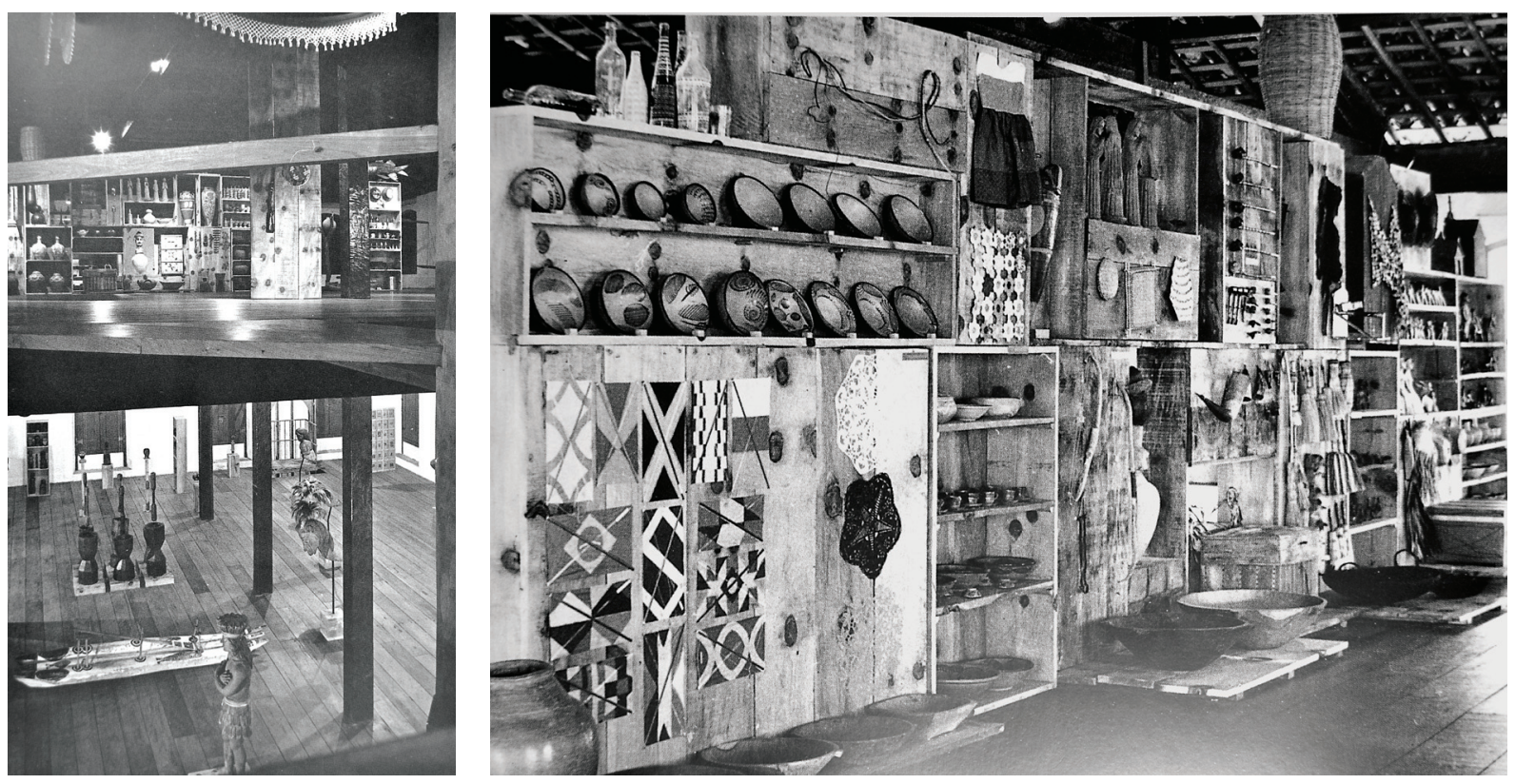



\subsection{BASES PARA INTERPRETAÇÃO DA CULTURA POPULAR}

A atuação de Lina Bo Bardi no Brasil entre os anos de 1947 a 1964 foi marcada por um período intenso de pesquisas e ações acerca da cultura moderna e sua conciliação com a chamada cultura popular. Este processo esteve permanentemente vinculado aos princípios de leitura elaborados pela arquiteta ainda na Itália a partir de suas experiências, além do contato direto com o debate sobre a formação da modernidade nacional italiana como visto no primeiro capítulo.

Embora tenha se aproximado de manifestações da cultura popular brasileira já em seus primeiros anos com os artigos para a revista Habitat, a descoberta do Brasil popular e arcaico para Lina se deu em grande parte no Nordeste, lugar onde a arquiteta encontrou uma originalidade sincera no meio da pobreza de recursos, configurando uma busca pelo entendimento sobre os meios de vida e de produção.

O empenho necessário à conquista do simples, é o mesmo percorrido pela aventura da modernidade, o mesmo instaurado pelos primeiros modernos na busca por uma estética decorrente das novas técnicas construtivas e do emprego de novos materiais, como reflexo também de uma nova ordem social, decorrente da organização industrial da produção e do trabalho.

(...)

na obra de Lina, o simples deve resultar numa síntese, num ideal de economia, porém dentro de um elenco de elementos cuidadosamente escolhidos para representar o despojamento e, sobretudo, combater a ideia burguesa de ostentação. ${ }^{178}$

178 JORGE, 1999, p.90-91 


\section{ARTE E ARQUITETURA PARA A VIDA DO HOMEM}

Uma das grandes preocupações presentes no trabalho de Lina é o alcance da arte, que é entendida como um exercício estético e técnico capaz de ser desenvolvido por qualquer pessoa independente de sua condição econômica, social e intelectual. A arte estaria inerente à vida a partir da criação de soluções para atender às necessidades cotidianas. Dessa maneira, se define a arte e a arquitetura para a vida do homem.

Para a construção da desejada modernidade nacional, no entanto, seria necessário que todos compreendessem essa dimensão da arte para que a comunicação entre os agentes não permanecesse dividida como estava até então, onde de um lado estavam os intelectuais detentores da Arte e formuladores das teorias e de outro o povo gerador da arte e executor da prática.

Como forma contribuir para a formação de uma modernidade que não conservasse essa cisão, Lina esteve envolvida na formulação de ações didáticas que tinham como intuito aproximar esses dois universos. Fez a "arte popular" compartilhar espaço com a "arte erudita" dentro de suas publicações e dos museus, mostrou a arte erudita desvinculada da crítica tradicional e de forma didática para que pudesse ser inteligível a qualquer tipo de público, e promoveu cursos no MASP e no MAMB que também trabalharam neste sentido.

\section{O COTIDIANO COMO CONSTRUÇÃO DA HISTÓRIA}

A percepção sobre a importância da história na construção do presente manifestou-se diversas vezes nos textos, nas exposições e na arquitetura de Lina. Esta visão, que tem origem em sua formação na Escola de Roma, passa por uma análise que chega a definição de presente histórico.

Nas Crônicas do Diário de Notícias de Salvador, ao falar sobre a cidade, Lina reforçou a importância da preservação do patrimônio como parte de uma iniciativa moderna, acreditando que o respeito a evolução histórica do lugar manteria as condições de preservação da autenticidade da cultura do povo.

Em seus textos é recorrente a crítica ao conceito de cidade idealizada, que consideraria a cidade como elemento estanque a ser trabalhado na prancheta. A arquiteta incluiu ainda nesta crítica a ação do mercado imobiliário como forma de prática dessa cidade idealizada de maneira estratégica para captação do lucro. Para ela, a intervenção nas cidades deveria se pautar nos avanços da tecnologia e ao mesmo tempo levar em conta os valores culturais sedimentados. 
O conceito de recuperação do patrimônio seria atrelado à ideia de "dar nova vida" ao lugar, transformando sua história em presente vivo. Processo este que foi aplicado pela arquiteta no restauro do conjunto do Unhão.

\section{O SABER FAZER}

O pensamento sobre o artesanato como possibilidade de formação de um desenho industrial foi carregado por Lina desde seu trabalho com Gio Ponti na Itália, e chega como possibilidade no Brasil. Entretanto, diante dos acontecimentos políticos e da maneira como a indústria foi desenvolvida no país, o que restou de valoroso nesta produção para ser aplicado no desenho industrial nacional eram os meios de criação e a originalidade conferida às soluções de problemas cotidianos.

Os artigos da revista Habitat trouxeram várias amostras de possibilidades de soluções técnicas e estéticas para questões do dia a dia, como visto nas casas feitas pelo povo onde sua elaboração parte da construção do abrigo e chega nos pequenos utensílios domésticos.

O saber fazer popular estaria, então, ligado ao fato de que o povo, a partir da extração de materiais da natureza, ou ainda, reaproveitando os materiais descartados pela indústria e pelo consumo, seria capaz de produzir tudo aquilo de necessário para sua sobrevivência diária atingindo qualidades técnicas e estéticas.

Observa-se que em seus projetos Lina Bo Bardi procurou estabelecer elementos de diálogo direto com este saber fazer popular, como ocorre nas casas projetadas em 1958 e no caso do encaixe do carro de boi presente de diversas formas, cuja mais icônica encontra-se na escada do Unhão. 

CAPÍTULO 3

INVENÇÃO DA MEMÓRIA

SESC POMPÉIA E IGREJA DO ESPÍRITO SANTO DO CERRADO 



\subsection{ANTECEDENTES}

Ao longo dos anos, os princípios de leitura sobre a cultura popular formados a partir da experiência de Lina Bo Bardi na Itália e em suas primeiras décadas no Brasil, foram se consolidando e formando uma base interpretativa sobre o qual a arquiteta trabalhou em seus textos, exposições, no desenho de mobiliário e em sua arquitetura.

Após sair da Bahia em 1964, em decorrência da tomada do regime militar e o consequente fechamento do MAMB, Lina desenvolveu estudos para diversos projetos. Alguns não construídos, como o Museu para o Instituto Butantã em São Paulo, o Pavilhão de Exposições para o Parque Lage no Rio de Janeiro, o estudo urbanístico para a praia de Itamambuca em Ubatuba e uma fábrica de perfumes em Santana do Parnaíba. Entre os projetos construídos está a retomada do acompanhamento das obras do MASP na Avenida Paulista, inaugurado em 1968, a arquitetura cênica para peças de teatro e filmes, a Igreja Espírito Santo do Cerrado em Uberlândia, o SESC Pompéia em São Paulo, a Capela Santa Maria dos Anjos em Vargem Grande Paulista, o Teatro Oficina em São Paulo, além de outros projetos realizados em seu posterior retorno a Salvador. ${ }^{179}$

Todos esses casos carregaram o desenvolvimento do olhar de Lina sobre os elementos da cultura popular atribuindo a essa expressão um sentido mais metodológico do que estético. Sendo assim, procuramos aqui investigar de que maneira esses elementos registrados por Lina em seus escritos, exposições e projetos foram interpretados e incorporados em suas obras construídas utilizando os casos da Igreja do Espírito Santo do Cerrado (1976-1982) e do SESC Pompéia (19771986) em primeiro plano para esta análise. Consideramos que estes projetos, construídos

\footnotetext{
179 FERRAZ, 1993
} 
praticamente de forma simultânea, são importantes e representativos de um momento em que Lina utilizou

(...) o emprego de métodos primitivos, rudimentares, em suas obras de arquitetura e design, como uma tese para um desenvolvimento diferenciado - mais ainda - do Brasil em relação ao resto do mundo. Dizia que, infelizmente, o sofisticado requinte do trabalho indígena, de altíssima abstração estava irremediavelmente perdido, e que não se podia correr risco de folclorizar o que sobrara. (...) Então, propunha ser necessário usar o que restara da técnica acaboclada, lançar mão da grossura. ${ }^{180}$

Faz-se necessário ainda esclarecer que o recorte temporal determinado para este estudo tem seu início no ano de 1976, quando Lina quebra o silêncio de seus textos com o artigo "Planejamento Ambiental: 'Desenho' no Impasse" para a revista Malasartes ${ }^{181}$, inicia o projeto para a igreja de Uberlândia, e visita pela primeira vez a antiga fábrica da Pompéia para a intervenção que ocorreria a partir do ano seguinte.

Este momento foi marcado pela declarada desesperança da arquiteta em relação a tudo que vinha sendo construído para a elaboração de uma modernidade nacional, não só no sentido local, mas também no âmbito do andamento das discussões internacionais sobre uma possível superação da modernidade. "Na avalanche-câncer da desorientação tudo é englobado e desvanece numa obsolescência total, num rápido envelhecimento e perda de sentido, numa 'completa perda de metáfora'."182

Segundo a arquiteta, a utopia sobre a regeneração do homem através das artes foi revelada e sua produção se rendeu ao mundo das cifras. "A arte não é tão inocente: a grande tentativa de fazer do desenho industrial a força regeneradora de toda uma sociedade faliu e transformou-se na mais estarrecedora denúncia da perversidade de um sistema." 183 Restaria a urgente revisão do planejamento ambiental em todas as escalas, desde o desenho industrial até o urbanismo, de maneira que o recomeço partisse da aceitação de uma realidade sobre a lógica de produção industrial já estabelecida.

Assim, dando continuidade ao seu posicionamento já verificado na "Exposição Nordeste", de 1963, os objetos coletados por Lina, que faziam parte de um montante residual do capitalismo, foram transformados em documentos ativos de cultura com valor de denúncia nas posteriores exposições da

\footnotetext{
180 SUZUKI, 2010, p.92 (grifo do autor)

181 Editorial brasileiro de arte publicado entre os anos de 1975 e 1976 que trazia como característica os textos de grande caráter crítico sobre a produção artística e a cultura nacional

182 BARDI, Lina Bo. “Planejamento ambiental - "Desenho" no impasse”, Malasartes, Rio de Janeiro, no2, dez-fev 1975-1976, p.4

183 Idem
} 
arquiteta, e conforme Azevedo (1995, p.60) "é este o sentido da invenção da memória em Lina Bo: reintroduzir os objetos já esquecidos na memória, tornando-os ativos, pelo menos enquanto documentos de cultura. Neste esquema interpretativo incluirá tanto elementos já descartados do ponto de vista do ciclo industrial quanto objetos feitos manualmente."

As exposições passaram a apresentar este caráter de denúncia sobre a condição de vida de um povo que vivia à margem do desenvolvimento. Da mesma maneira, em seus textos do período pós-1964 Lina adota tal posicionamento e manifesta a perda de esperança em um projeto de Brasil Moderno com base na tradição popular.

Enquanto estava na Bahia, Lina acreditava na possibilidade do desenvolvimento da cultura brasileira de forma autônoma, fora de um colonialismo cultural, cujas bases estavam se formando em torno de uma estrutura favorável composta pela "existência de uma universidade em expansão (...), uma classe estudantil que, embora confusamente, e agindo às vezes em sentido contrário aos próprios interesses, estava no caminho mais certo para uma tomada de consciência política e cultural, mas sobretudo, o caráter profundamente popular da Bahia e de todo o Nordeste."184

No entanto, o golpe militar de 1964 fez cessar qualquer esperança de progresso neste sentido ao provocar completa estagnação cultural. No texto "Cinco anos entre os brancos", Lina diz ainda que a criação de um museu culturalmente livre como o MAMB só foi possível graças a um momento de "equívoco" no país, no qual outros movimentos culturais se desenvolveram em torno da pesquisa sobre a cultura popular. "Não foi um programa ambicioso, era apenas um caminho"185, que as circunstâncias políticas do país não deixaram evoluir.

Conforme a arquiteta, com o plano de modernização industrial empreendido rapidamente durante o regime militar, o país acabou por repercutir na falência de um projeto de desenvolvimento cultural importante. Esta aceleração da modernização além de influir nos produtos utilitários também teve resultados alarmantes na produção das cidades e no processo de desvalorização da cultura local.

Os marcos sinistros da especulação imobiliária, o não-planejamento habitacionalpopular, a proliferação especulativa do desenho industrial - gadgets, objetos - na maioria supérfluos - pesam na situação cultural do país, criando gravíssimos entraves, impossibilitando o desenvolvimento de uma verdadeira cultura autóctone. Uma tomada de consciência coletiva é necessária, qualquer divagação é um delito na hora

184 BARDI, Lina Bo. Cinco anos entre os brancos. In: RUBINO; GRINOVER, 2009, p. 133

185 BARDI, Lina Bo. Cinco anos entre os brancos. In: RUBINO; GRINOVER, 2009, p. 131 
atual. A desculturação (sic) está em curso. Se o economista e o sociólogo podem diagnosticar com desprendimento, o artista deve agir, além de ligado ao intelectual, como parte ligada ao povo ativo. ${ }^{186}$

Entretanto, mesmo diante da frustração sobre os rumos tomados pelo país, Lina ainda acreditava na possibilidade de ação a partir de suas potencialidades, como podemos ver em seu relato para o IAB em um conjunto de depoimentos organizados em 1979, cujo tema era Arquitetura e Desenvolvimento Nacional: "o Brasil tem possibilidade de ser profundo nas coisas, por suas raízes populares. Vocês têm possibilidades muito grandes, só olhando com um pouco mais de atenção, de se apoderar das realidades verdadeiras o país. Isto vale para a arte para a arquitetura e para muitos outros assuntos." ${ }^{187}$

Em seu texto "Um balanço dezesseis anos depois", Lina alerta para a urgência de uma revisão cultural que deveria ser feita principalmente pelos artistas brasileiros após o reconhecimento da derrota sobre o desejo de se construir uma indústria tomando como base a produção popular. Produção que inclusive é questionada pela arquiteta ao constatar que "o artesanato como corpo social nunca existiu no Brasil, o que existiu foi uma imigração rala de artesãos ibéricos ou italianos e, no século XIX, manufaturas. O que existe é um pré-artesanato doméstico esparso, artesanato nunca." ${ }^{188}$

Também para Lina a atenção à distinção entre o pré-artesanato e o folklore seria fundamental para que não se caísse na armadilha do romantismo paternalístico criado pela "Grande Cultura central, para eliminar, colocando no devido lugar, incômodas e perigosas posições da cultura popular periférica." ${ }^{189}$ Sendo assim, fazia-se necessário avaliar profundamente, de maneira crítica e objetiva, os meios de produção popular para que se encontrasse sua verdadeira significação dentro dos novos processos modernos: “Procurar com atenção as bases culturais de um País, (sejam quais forem: pobres, míseras, populares) quando reais, não significa conservar as formas e os materiais, significa avaliar as possibilidades criativas originais". ${ }^{190}$

O conteúdo dos textos de Lina caminhou lado a lado com as propostas de sua arquitetura, que também colocava em discussão seu modo de produção e sua relação com as pessoas e com o ambiente. Conforme Grinover (2010, p.21),

(...) percebemos que na estrutura de seus textos há sempre uma indagação crítica e uma atitude propositiva. Mas mesmo em face dos eventos repressores de 1964-69, a

\footnotetext{
186 BARDI, Lina Bo. Um balanço dezesseis anos depois. In: SUZUKI, 1994, p.11

187 BASTOS,M.;ZEIN,R. Brasil: Arquiteturas após 1950. São Paulo: Editora Perspectiva, 2010. p.208

188 BARDI, Lina Bo. Um balanço dezesseis anos depois. In: SUZUKI, 1994, p.12 (grifo do autor)

189 BARDI, Lina Bo. Por que Nordeste?. In: SUZUKI, 1994, p.20 (grifo do autor)

190 BARDI, Lina Bo. Por que Nordeste?. In: SUZUKI, 1994, p.21 (grifo do autor)
} 
arquiteta procurou uma saída para os abismos de um ideário modernista que não se completou na realidade, seja artística, seja social ou econômica em nosso país. Na década de 80, a questão não era mais o 'ser ou não ser' do objeto artístico e sua percepção, mas sim o contexto, o ambiente, o habitat. Nesse ponto estaria a natureza da conexão entre obra, artista e usuário.

Dessa maneira,

Lina se voltará para a esfera do residual, do que fica à margem do sistema industrial, enquanto resgate de uma dimensão humana perdida. Neste sentido apresenta os projetos da Capela em Ibiúna - troncos de madeira, telhado de palha, e da Igreja do Espírito Santo do Cerrado - tijolos, paliçada, telhas de barro. ${ }^{191}$

Neste cenário, a invenção da memória ${ }^{192}$ aparece como um movimento de resistência ao fim do movimento cultural de afirmação nacional, ainda que Lina tenha preservado a poética de suas criações. Jorge $(1999$, p.85) propõe o entendimento sobre "os processos pelos quais a arquiteta Lina Bo Bardi transformava a realidade e a apreendia em obra de arquitetura" através da interpretação de Italo Calvino sobre a visibilidade na literatura, que diz sobre o caráter imaginativo e criativo do poeta. "A primeira impressão, quando observamos o trabalho da arquiteta, é a de estarmos presenciando uma chuva de imagens provenientes de uma inesgotável fonte de imaginação." ${ }^{193}$ Entretanto, todos os elementos constituintes de suas obras são carregados de significados e dos "porquês" necessários à racionalidade pretendida na arquitetura.

A realização do trabalho de levantamento e de registros da realidade nacional, o exercício de invenção da memória brasileira, pode ser caracterizado como uma busca sempre presente em Lina, uma tentativa de entender o País, procurar decifrar os seus significados. Sua caminhada por todos os cantos do Brasil do qual Lina dizia se sentir [...] cidadão de todas as cidades, desde Cariri, ao Triângulo Mineiro, às cidades do

\footnotetext{
${ }^{191}$ AZEVEDO, 1995, p.61

192 O período adotado refere-se ao período descrito em AZEVEDO, Mirandulina M. M. A experiência de Lina Bo Bardi no Brasil (1942-1992). São Paulo, FAAUSP, Dissertação de Mestrado, 1995. Azevedo procura neste texto estudar o percurso de Lina Bo Bardi no Brasil estabelecendo uma articulação entre suas experiências como arquiteta e as questões políticas e culturais do país. Considerando que este percurso de quarenta e cinco anos atravessou um momento de intensa transformação na política e na cultura nacional, a autora procura dividir a atuação de Lina em três fases, de modo que, "A primeira fase - Projeto de Brasil Moderno (1947-1957), onde a instância cultural mais geral era perpassada pela ideologia da Modernidade, sendo praticamente assimilada por Lina Bo Bardi. As outras duas fases - Memória do Brasil Arcaico (1958-1964), e principalmente a última - Invenção da Memória Brasileira (1976-1992) são respostas originais a tendência regressiva do meio cultural no país; de um lado, influenciado em grande parte pelas sequelas do regime militar e de outro pela própria situação recessiva do capitalismo a nível mundial." (AZEVEDO,1995,p.2-3)
}

193 JORGE, 1999, P.85 
interior e às da fronteira ${ }^{194}$, lembra e remonta o seu próprio período de atuação italiana, quando também se dedicou, várias vezes, a percorrer seu país na condição de repórter dos periódicos de arquitetura, buscando da mesma forma o conhecimento da essência da nação no seu povo, para fundar a partir dessa essência, uma cultura moderna. ${ }^{195}$

194 BARDI, Lina Bo. Curriculum Literário. In: FERRAZ, 1993, p.12

195 PEREIRA, 2007, p.35 


\subsection{PREMISSAS PARA DOIS PROJETOS DE LINA BO BARDI}

A cultura popular esteve presente nos projetos de Lina Bo Bardi a partir de uma interpretação metodológica e de um posicionamento político que a fazia transformar em ação seus questionamentos sobre os meios de produção industrial colocados em detrimento da riqueza da cultura tradicional.

Neste sentido, embora possamos observar em suas obras a inserção de referências diretas e a utilização de objetos de fatura popular, fica evidente que para a arquiteta consolida-se ao longo do tempo a ideia de que "a brasilidade seria uma questão técnica e socialmente inerente às responsabilidades políticas do arquiteto" (e que) "a cultura popular é uma questão estratégica para Lina Bo Bardi."196

No desenvolvimento do projeto para a Igreja do Espírito Santo do Cerrado nota-se que a estreita relação estabelecida entre a igreja e a população local repercutiu em um esforço conjunto para a construção de uma obra de poucos recursos, mas que possuía um projeto sofisticado e que levava em conta a capacidade de mobilização do povo para a construção de um espaço próprio.

Já no caso do SESC Pompéia, o dado sobre a tradição popular aparece nas mais diversas formas, tanto através da apropriação dos espaços da antiga fábrica, quanto pela interferência direta dos operários nos resultados da obra, ou ainda através de elementos que procuram aproximar o homem da natureza.

Para que possamos montar nossa breve análise sobre os elementos da cultura popular adotados para a invenção destas memórias, os projetos são tratados aqui a partir de questões inerentes a suas concepções, não entrando no mérito de suas alterações posteriores. Tampouco são tratadas as

196 ROSSETTI,2002,p.7 
minúcias de projeto e construção. Desse modo, reforçamos o objetivo de entender os procedimentos de Lina para a criação dos projetos a partir de suas condições iniciais.

\section{IGREJA DO ESPÍRITO SANTO DO CERRADO}

O projeto para a Igreja do Espírito Santo do Cerrado, desenvolvido durante os anos 1970, configurouse como uma ação política onde Lina pôde trabalhar em função das necessidades do povo e com o povo a partir do conhecimento de técnicas tradicionais de construção e com a simplicidade de materiais necessária a uma obra que seria gerada com poucos recursos e em esquema de mutirão.

Por seu caráter social e inventivo este é um projeto registrado em muitos dos trabalhos trabalhos acadêmicos e publicações que tratam da obra de Lina Bo Bardi. Contudo, um estudo mais aprofundado elaborado por Lazzarin (2015) ${ }^{197}$ traz os pormenores do desenvolvimento desta obra apresentando textos publicados no período e cartas trocadas por Lina Bo Bardi, Edmar de Almeida e Frei Egidio Parisi que mostram a forte relação deste projeto com a comunidade e a possibilidade de conciliação entre a prática e os ideias e percepções manifestadas por Lina em seus textos publicados a partir de 1976.

O convite para a construção do conjunto religioso partiu do Frei Egidio Parisi, membro da Ordem Franciscana vinda da Itália nos anos 1950 e instalada no Triângulo Mineiro, que atuava no desenvolvimento social local por meio da educação de da cultura. A aproximação de Lina ao freis franciscanos ocorreu através de Edmar de Almeida ${ }^{198}$, que vivenciava as ações da igreja junto à população do cerrado e que tinha conhecimento da necessidade da construção de um espaço dedicado à paróquia e às atividades comunitárias no bairro do Jaraguá.

Conforme Lazzarin $(2015$, p.16), Frei Egidio era também um grande admirador da cultura brasileira, colecionador de objetos locais e participante ativo da formação cultural da região.

\footnotetext{
"Frei Egídio manifestava continuamente suas ideias à necessidade de desenvolvimento social, intelectual e cultural sobre a materialidade da vida moderna. Percorreu o centro-oeste brasileiro em missão e concretizou ações, principalmente, nas cidades de Uberlândia, Araguari e Canápolis, onde atuou junto à direção da
}

\footnotetext{
197 Para informações mais aprofundadas sobre a construção desse conjunto e sobre os processos posteriores ver LAZZARIN, Ariel L. "A Igreja Divino Espírito Santo do Cerrado e suas alternativas à arquitetura brasileira". São Carlos, EESC-USP, dissertação de mestrado, 2015

198 O artista plástico mineiro Edmar de Almeida, por sua vez, foi apresentado a Lina Bo Bardi por Flávio Império com quem a arquiteta vinha desenvolvendo trabalhos de cenografia entre os anos 1960 e 1970
} 
Paróquia Nossa Senhora de Fátima, no atual Bairro Martins. Possuía capacidade de transitar entre elites e pobres e canalizava investimentos oriundos do sucesso econômico local para obras que respondessem à carência social desse mesmo processo desenvolvimentista."

Ao tomar conhecimento da dimensão do papel social desta obra, a resistência inicial de Lina Bo Bardi ao convite para este projeto, justificada por seu posicionamento comunista e ateu, em pouco tempo deu lugar à concepção de um projeto que substituiria a pequena construção de tábuas erguida pelo povo ao lado do terreno da futura igreja de Dona Lina.

Em 1976 o projeto é iniciado pela arquiteta que toma como base as necessidades da comunidade descritas por Edmar de Almeida e pelo Frei Egidio Parisi ao mesmo tempo em que leva adiante alguns princípios de projeto elaborados em estudos anteriores.

Assim seguiu o desenvolvimento do projeto, cartas de Edmar de Almeida Ihe enviavam os desejos, necessidades e acontecimentos da obra enquanto Lina, entre uma visita e outra ao local, retornava as cartas com desenhos e instruções para construção que seria feita por operários contratados e por moradores locais em mutirão. A obra seguiria também amparada pelo cálculo de estruturas desenvolvido pelo engenheiro Rodolfo Ochoa ${ }^{199}$.

\section{SESC POMPÉIA}

Em 1977, ainda envolvida no projeto para a igreja de Uberlândia, a convite da diretoria do SESC, Lina iniciou o projeto para um novo conjunto no bairro da Pompéia, em São Paulo. Um estudo para esta nova unidade já havia sido feito anteriormente pelo arquiteto Júlio Neves ${ }^{200}$, cujo projeto considerava a utilização apenas do terreno limpo para uma construção completamente nova, o que implicaria na demolição dos edifícios da antiga fábrica lá instalada, contudo, segundo ele, o projeto não foi adiante por questões de custos. ${ }^{201} \mathrm{Em}$ virtude da mudança de postura da diretoria da instituição quanto à possibilidade de preservação da fábrica existente no terreno ${ }^{202}$, Lina Bo Bardi, que anos antes havia

\footnotetext{
199 Engenheiro Civil chileno, amigo do Frei Egídio, e que colaborou com a construção do conjunto religioso do Jaraguá e com uma nova casa para os frades franciscanos no mesmo período (LAZZARIN, 2015, p.48)

200 Júlio Neves (1932) arquiteto paulista e presidente do MASP entre os anos de 1994 e 2007

201 OLIVEIRA, Raíssa Pereira Cintra de Oliveira. Permanência e inovação: o antigo e o novo nos projetos urbanos de Lina Bo Bardi. São Paulo, FAUUSP, Dissertação de Mestrado, 2008. p.19

202 Edifício residencial do século XIX transformado em centro para comércio e lazer na década de 1960, localizado em São Francisco, nos Estados Unidos
} 
realizado a restauração do conjunto do Unhão para a instalação do MAMB em Salvador, foi convidada para repetir a experiência na fábrica da Pompéia ${ }^{203}$.

Tratava-se da reforma e adaptação da fábrica construída no ano de 1938 pela firma Mauser \& Cia Ltda, utilizada pela Fábrica Nacional de Tambores da IBESA (Indústria Brasileira de Embalagens) e posteriormente como local de linha de montagem de uma indústria de geladeiras. Em 1971 o SESC comprou o terreno da fábrica, e entre os anos de 1973 e 1976 utilizou o local para suas atividades, mesmo que de forma ainda precária. ${ }^{204}$

O conhecimento técnico e o olhar atento aos costumes populares fizeram com que Lina pautasse a concepção do SESC Pompéia fundamentalmente em dois pontos: técnica e tradição. A arquiteta também participou ativamente da definição programática do edifício e do plano de atividades da instituição naquele conjunto, o que incluiu o planejamento de suas conhecidas exposições.

Para Jorge (1999), esta obra tira do silêncio a arquitetura brasileira dos anos 1970, tornando-se também um marco diante da prática e do ensino sobre a revitalização no país.

Este projeto é um acontecimento para a geração de arquitetos formada nos anos 80, que reconhecia na obra um ponto de inflexão na história da arquitetura contemporânea; dissonante num contexto marcado pela afasia; extravagante, provocativo e delirante onde só se via repetição; poético e criativo, ocupando um vazio de debates e reflexão. ${ }^{205}$

Como destaca Rossetti (2002), no SESC Pompéia o moderno estava na escala das preocupações, no desejo do alcance social do projeto, no espaço contínuo, no uso de tecnologias arrojadas, na preocupação com a transformação dos meios técnicos de produção e no desejo de participação democrática. Por outro lado, o cultural estava na forma de relacionar materiais e referências culturais, "na vitalidade dos espaços e na singela materialidade da obra."206

\footnotetext{
203 Para mais informaç̃̃es sobre o projeto para o SESC Pompéia ver:

LATORRACA, Giancarlo (org.). Cidadela da liberdade. São Paulo: Instituto Lina Bo e P.M. Bardi, 1999

${ }^{204}$ ALMEIDA,2009,p.107

205 JORGE, 1999, p.108

206 ROSSETTI,2002, p.37
} 


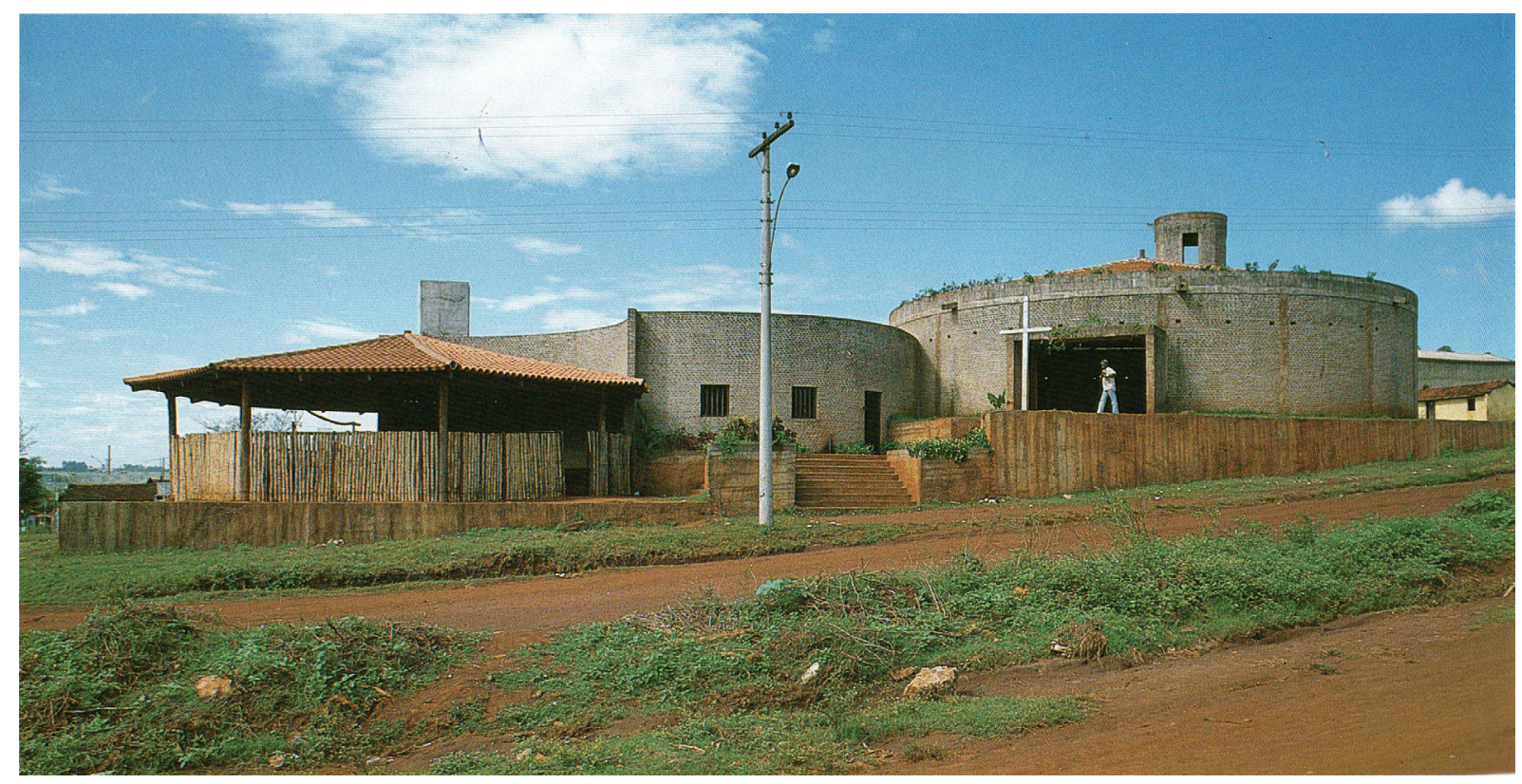

FIG.84 Igreja do Espírito Santo do Cerrado após a construção

Fonte: FERRAZ, 1993, p.215
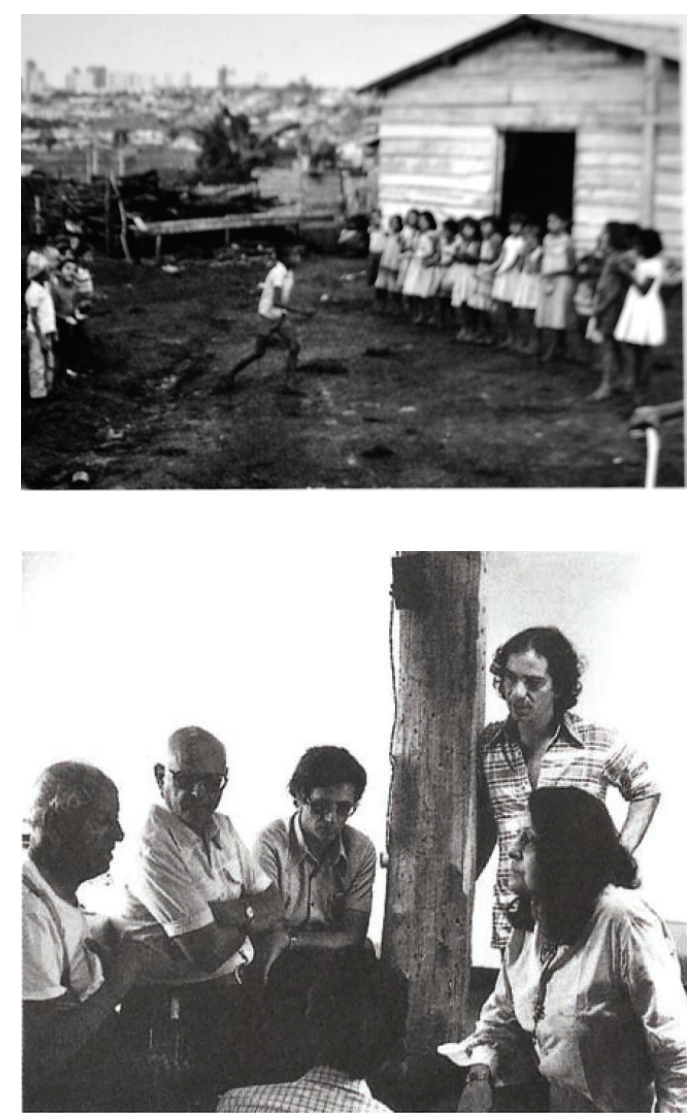

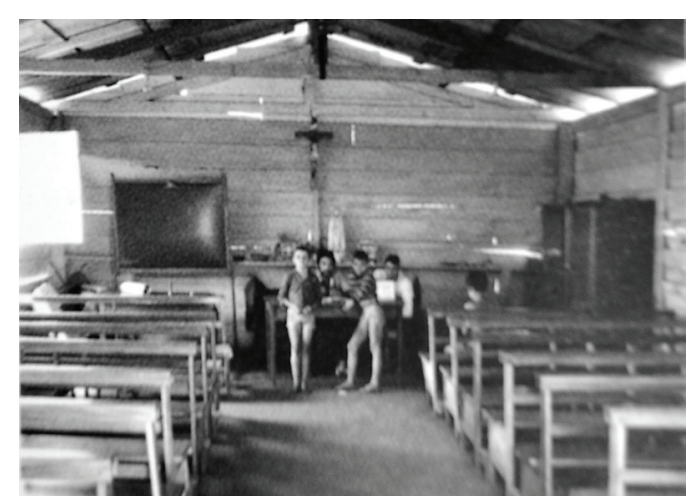

FIG.85-86 Igreja de tábuas construída ao lado do terrno da nova construção ainda vazio Fonte: FERRAZ, 1999

FIG.87 Lina em reunião para definições de projeto Fonte: FERRAZ, 1999 


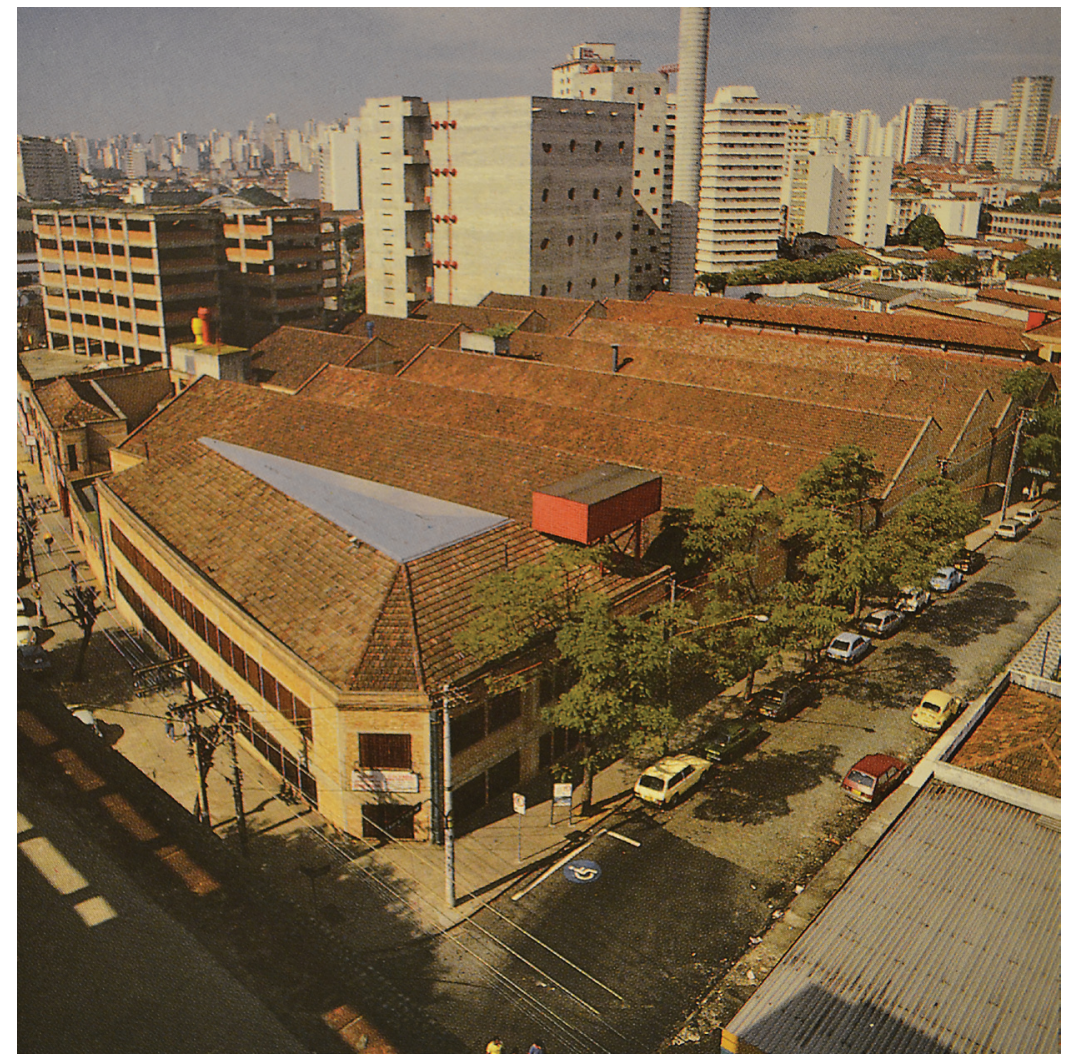

FIG.88 SESC Pompéia após a restauração dos galpões e construção das novas torres Fonte: FERRAZ, 1993, p.220

FIG.89 Vista do conjunto da fábrica da Pompéia antes da reforma Fonte: OLIVEIRA, 2007, p.16

FIG.90 Utilização do galpão da fábrica antes do restauro Fonte: OLIVEIRA, 2007, p.22
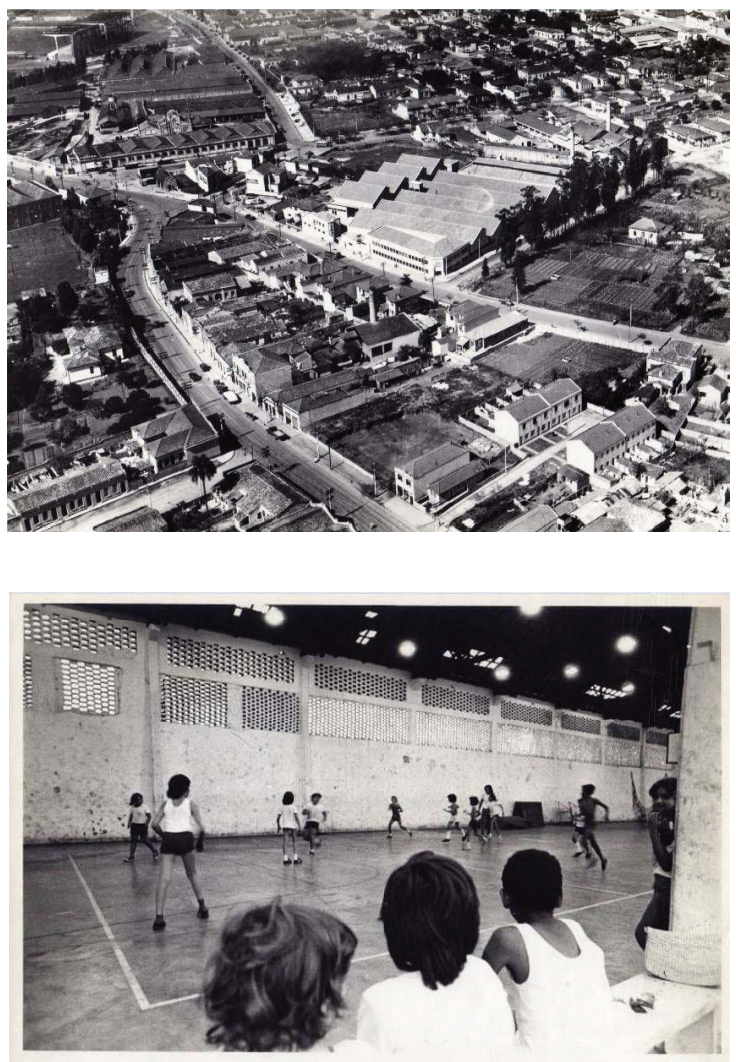


\subsection{ARQUITETURA PARA A VIDA DO HOMEM}

As conhecidas aquarelas de Lina Bo Bardi, cuja iniciação esteve a cargo de seu pai Enrico Bo, foram marcantes em sua trajetória, tanto nos editoriais em que participou como ilustradora quanto em seus projetos. Os primeiros desenhos da arquiteta, ainda criança, que representavam de maneira realista casas e figuras femininas, anos depois passaram a retratar o cotidiano urbano, tornando-se um exercício de percepção e registro daquilo que acontecia a sua volta. Talvez essa tenha sido uma das primeiras formas de aproximação da arquiteta com as noções de narrativa que permearam seus projetos de arquitetura e fizeram com que o olhar para o cotidiano e para a cultura do povo extrapolasse o limite do reconhecimento para o nível da compreensão.

Anos mais tarde, outra grande influência para suas aquarelas veio a partir dos trabalhos do arquiteto Gio Ponti, com quem Lina trabalhou em diversos tipos de projetos, como já mencionado anteriormente neste trabalho.

A narrativa construída nos desenhos de Lina Bo Bardi para seus projetos tinha como objetivo comunicar suas ideias e dizer sobre seus pensamentos e propostas para que o modo de vida dos lugares de intervenção fosse preservado, mesmo que seus desenhos não configurassem a "melhor representação" para a arquitetura. 


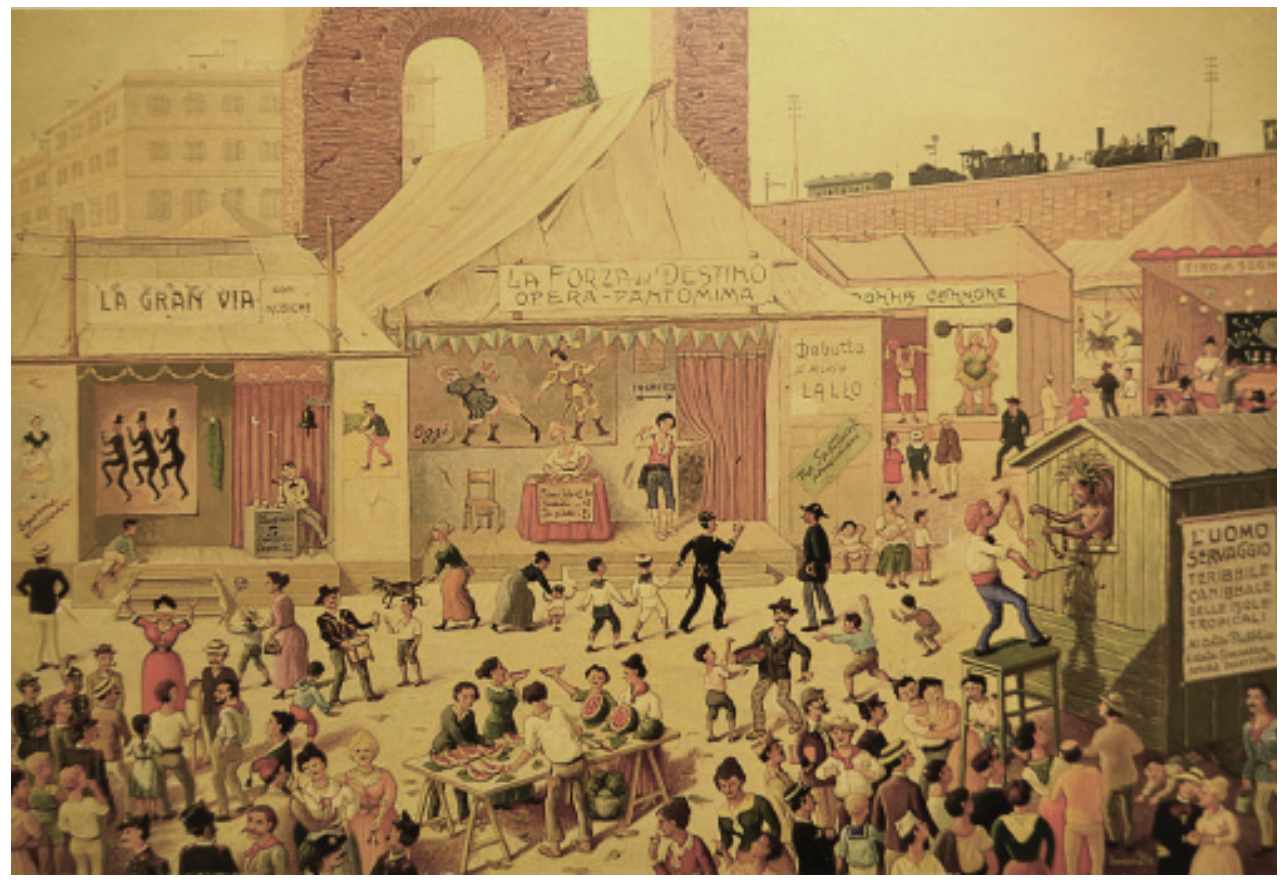

FIG.91 "Festa de Noantri in Trestevere" Lina Bo Bardi, 1929

Fonte: FERRAZ, 1993, p.18

FIG.92 "Piazza Guglielmo Pepe" - Enrico Bo Fonte: FERRAZ, 1993, p.33

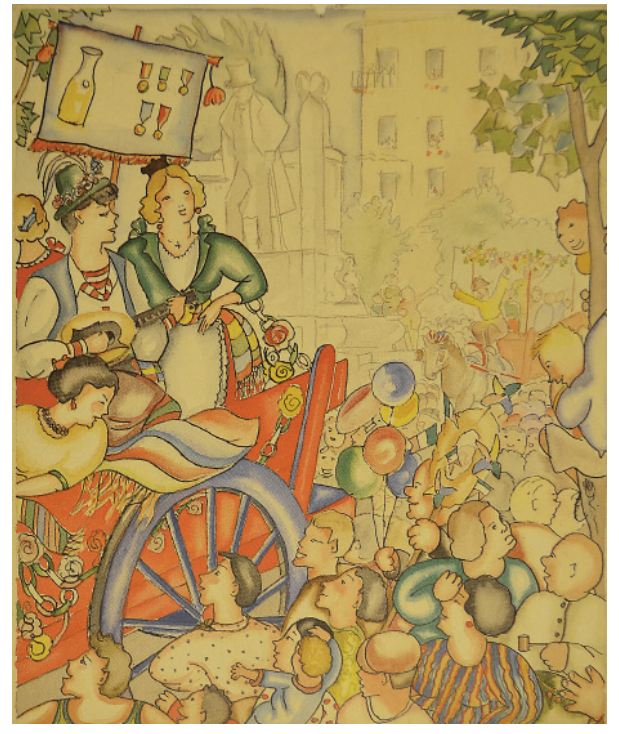

FIG.93 Figurinos para peça de teatro - Gio Ponti, 1939

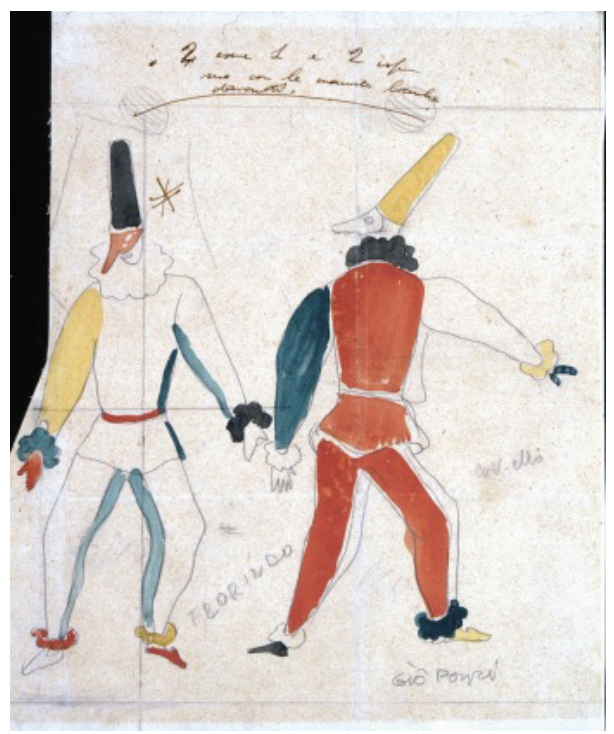




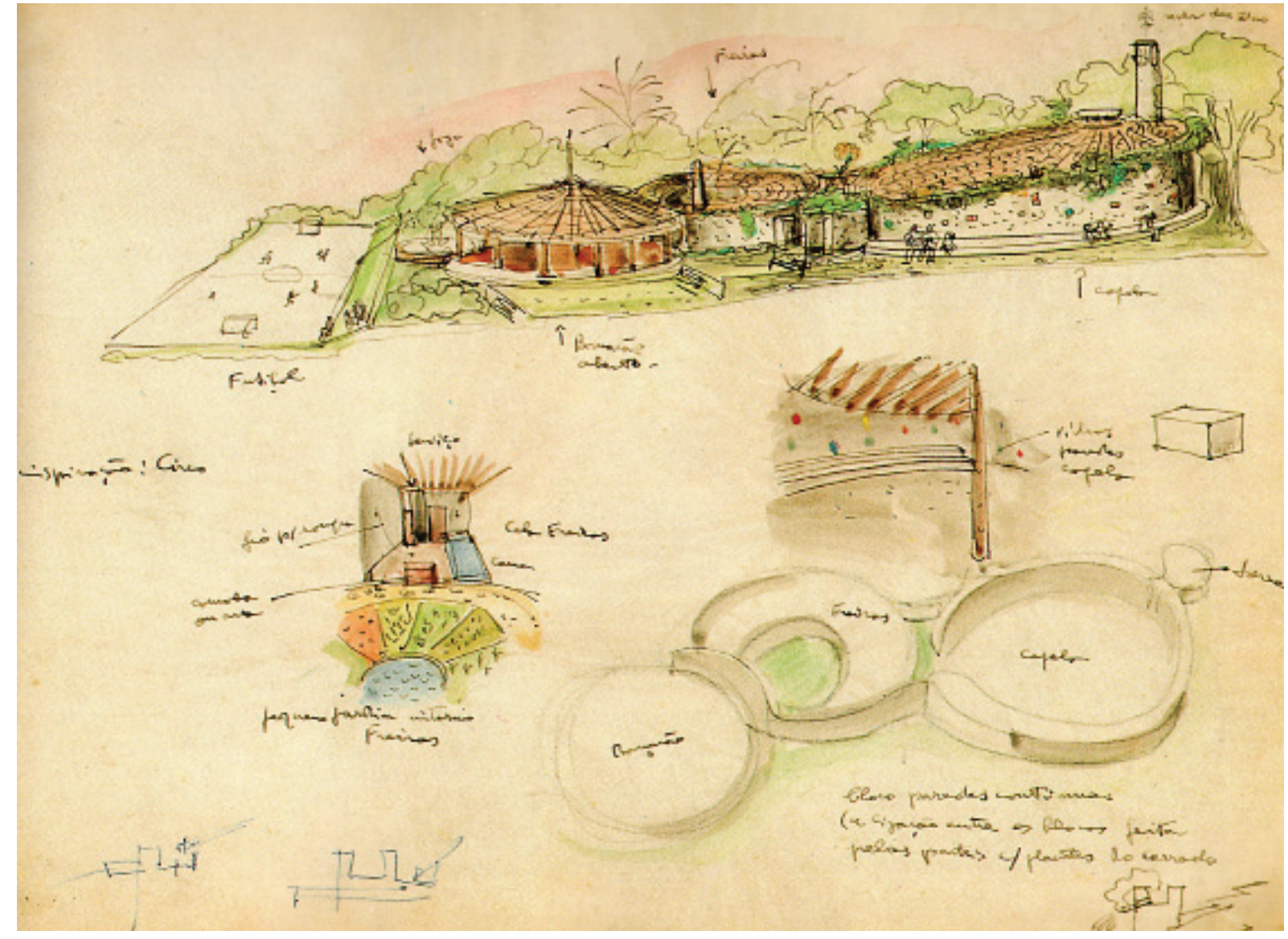

FIG.94 Aquarelas de Lina Bo Bardi para estudo do projeto para a Igreja do Espírito Santo do Cerrado Fonte: FERRAZ, 1993, p.211

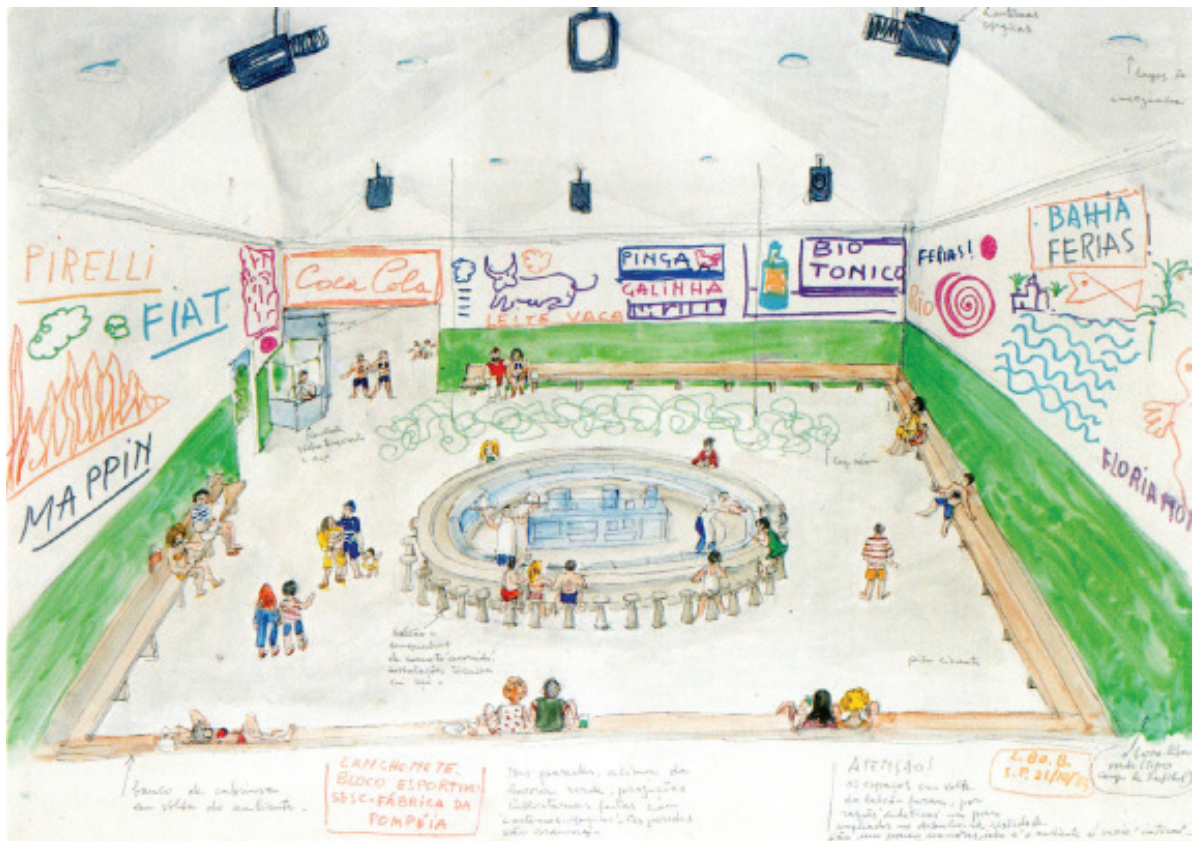

FIG.95 Aquarelas de Lina Bo Bardi para estudo do projeto para o SESC Pompéia Fonte: FERRAZ, 1993, p.211 
A ênfase nas ideias e a coerência entre elas e as imagens geratrizes do projeto, ao mesmo tempo em que evitam a retórica do desenho pelo desenho, desmistificam o ato criador em prol de uma pedagogia poética. O projeto parece resultar de um processo de trabalho amistoso e afetivo ofertado à sociedade, ao mesmo tempo que demonstra a validade das especulações no âmbito da linguagem da arquitetura. ${ }^{207}$

Esta construção imaginária do cotidiano inerente à concepção do edifício se mostra bastante evidente tanto nos croquis para a Igreja do Espírito Santo Cerrado, quanto para o SESC Pompéia. Cada desenho ilustra a vida dos ambientes representados, como se quisesse demonstrar que não há arquitetura sem o homem agindo sobre o espaço construído. Neste sentido, o entendimento das condições e relações pré-existente nos lugares de intervenção foi sempre um dado fundamental para a elaboração dos projetos da arquiteta.

\section{IGREJA DO ESPÍRITO SANTO DO CERRADO}

As descrições de Edmar de Almeida para a concepção do projeto para a igreja do Jaraguá não se limitavam apenas às questões funcionais do conjunto, havia o desejo de que aquele fosse um lugar de acolhida a população local em suas atividades comunitárias e que fizesse parte da vida daquelas pessoas de forma profunda, assim como demonstra o trecho de uma de suas cartas, escrita em 1976, reproduzida por Lazzarin (2015, p.44):

CAPELA DO SANTO ESPÍRITO - Apesar da casa e o barracão serem os primeiros a construir pois, as irmãs tomarão conta da construção, o pessoal que primeiro a igreja. D. Lina faça-a bela e simples, retrato desse povo tão bom. O gosto que têm pela beleza é mais que um anseio, espécie de fome e apetite que os tira do peso do trabalho, do sofrimento, das carências. Acho triste, a maioria dos artistas brasileiros não percebem o conceito de beleza que traz o povo e o que seria e é arte para eles... Toda riqueza que trazem impossível de extravasá-la no cotidiano aparece nos domingos, no descanso da noite, à beira do fogo, nas festas, nas canções, procissões. Alegria simples e inteira, cristalina.

Lina Bo Bardi não só compreende a importância desta construção para comunidade como também procura ampliar a dimensão de sua proposta ao colocar em prática formas e arranjos já estudados em

\footnotetext{
207 JORGE, 1999, p.87
} 
outros projetos combinados a um modo de produção que poderia se aproximar de outras populações com poucos recursos, mas com demandas essenciais como, por exemplo, a habitação.

Nossa experiência não é a de uma "elite folclórica", mas, um teste de viabilidade, tendo em vista a possibilidade de uma produção habitacional ao alcance econômico do povo e realizada com a elaboração ativa desse mesmo povo. ${ }^{208}$

\section{A POÉTICA DAS FORMAS}

Os estudos para o conjunto da igreja desde o início apresentavam a forma curva e a utilização de materiais ligados ao ambiente já verificados em projetos de Lina Bo Bardi desde os anos 1950. A Casa Valéria P. Cirell e a Casa do Chame-Chame, ambas de 1958, são representativas da consolidação deste movimento iniciado desde a idealização da Casa de Vidro.

A busca pela utilização de formas orgânicas e materiais tradicionais presentes em seus projetos, ainda que trouxessem elementos coincidentes, demonstrando a tentativa de amadurecimento de determinadas ideias, sempre estava intimamente ligada à relação "solo, clima e ambiente" e às necessidades específicas de cada caso.

No projeto para a Igreja do Espírito Santo do Cerrado, o programa foi implantado num terreno em declive cujas construções cilíndricas foram dispostas em três níveis com acessos independentes a partir da rua. Do nível mais alto para o mais baixo estão a igreja, a casa paroquial, um barracão para reuniões e festas com uma pequena churrasqueira ao lado e no quarto nível, mais baixo, foi mantido o campo de futebol $^{209}$ já utilizado pela população.

O volume central, destinado à residência das freiras, elaborado a partir de um centro demarcado por um claustro de terra batida para onde as janelas se voltavam, foi projetado com o dimensionamento mínimo possível para os ambientes, tornando o espaço condizente com o que pregam os franciscanos por meio de sua simplicidade e inexistência de apego material ${ }^{210}$.

\footnotetext{
208 Lina em FERRAZ, 1993, p.214

209 Que hoje dá lugar a um salão paroquial.

210 Hoje essas divisões internas sofreram diversas alterações em virtude da instalação da administração da igreja no lugar da residência.
} 
As formas circulares, já experimentadas por Lina em projetos anteriores, e a maneira como o programa foi distribuído ao longo do terreno trazem sentidos que vão além do significado formal, conforme as interpretações de Oliveira (2014) e Jorge (1999):

Interior e exterior ondulantes, sempre em movimento, nesse conjunto tudo gira, nada é estático. Como uma engrenagem, um mecanismo onde cada parte depende da outra, o conjunto funciona em ajuda mútua, onde cada peça é capaz de transmitir movimento e força ao todo. ${ }^{211}$

(...) alia no espaço físico e territorial, os temperamentos e características típicos de Minas Gerais: o sentimento religioso do mundo e a sociabilidade que o celebra - as festas: a quermesse, a folia, a pelada. A circularidade está presente no circo (referência citada por Lina), mas também no ciclo desses rituais e na visão de um tempo e uma natureza que se expressam ciclicamente para os olhos do nosso povo. ${ }^{212}$

Segundo Oliveira (2014), Lina procurou neste projeto reverter os signos que levam ao transcendente e começa esse processo ao girar o posicionamento do altar para o sentido norte-sul ao contrário do convencional leste-oeste. Também o centro do conjunto, usualmente atribuído à nave, neste projeto é deslocado e multiplicado, contrariando assim a visão centralizadora das religiões ocidentais. ${ }^{213}$

\section{SESC POMPÉIA}

Desde a primeira visita à fábrica da Pompéia Lina Bo Bardi manifestou especial atenção não só à construção já existente e de valor peculiar para a arquitetura, mas também às relações humanas já estabelecidas naquele local.

Entrando pela primeira vez na então abandonada Fábrica de Tambores da Pompeia, em 1976, o que me despertou curiosidade, em vista de uma eventual recuperação para transformar o local num centro de lazer, foram aqueles galpões distribuídos racionalmente conforme os projetos ingleses do começo da industrialização européia, nos meados do século XIX.

\footnotetext{
211 OLIVEIRA, Olívia. Lina Bo Bardi: Obra construida. Buit work. Barcelona: Gustavo Gilli, 2014. p.90

212 JORGE, 1999, p.110

${ }^{213}$ OLIVEIRA, 2014, p.91-92
} 
Todavia, o que me encantou foi a elegante e precursora estrutura de concreto. Lembrando cordialmente o pioneiro Hennebique, pensei logo no dever de conservar a obra. (...)

Na segunda vez que lá estive, um sábado, o ambiente era outro: não mais a elegante e solitária estrutura hennebiquiana mas um público alegre de crianças, mães, pais, anciãos passava de um pavilhão para outro. Crianças corriam, jovens jogavam futebol debaixo da chuva que caía dos telhados rachados, rindo com os chutes de bola na água. (...) Pensei: isso tudo deve continuar assim, com toda essa alegria. ${ }^{214}$

Para o projeto do SESC Pompéia Lina Bo Bardi operou mais uma vez a partir da combinação entre o dado humano e suas relações para estabelecer a configuração e os dados técnicos da construção, consolidando talvez da forma mais completa a possibilidade e o desejo da integração entre homem e arquitetura.

\section{A POÉTICA DAS FORMAS}

Lina Bo Bardi segue transformando significados ao levar a rua para dentro do SESC Pompéia, por onde acontecem os principais acessos para os edifícios do conjunto. Por ela faz-se o acesso direto à administração, ao galpão de atividades gerais, ao teatro, aos ateliês, ao almoxarifado, às oficinas de manutenção e ao restaurante-choperia.

Nesta rua central, a integração entre o homem, o ambiente, a arquitetura e a natureza é constituída através da configuração dos espaços e da utilização de materiais que potencializam a vida daquele lugar. A areia de assentamento dos paralelepípedos trocada por terra permite o crescimento de plantas entre as pedras, e nas laterais do passeio as valas de concreto revestidas com seixos rolados permitem que se possa ouvir o barulho da chuva caindo no chão. Enquanto o trânsito de pessoas em um único eixo promove a convivência.

Essa mesma ideia dinâmica de integração com o ambiente também permeou o galpão de atividades gerais, para o qual Lina estudou soluções que distribuíssem o programa em níveis com diferentes pés diretos acessados por ramplas sinuosas. As rampas não permaneceram no projeto final, mas os diferentes níveis foram criados a partir de volumes de concreto aparente para que se pudesse distribuir a biblioteca, o espaço para exibição de vídeos, o espaço de estar e o galpão de exposições.

\footnotetext{
214 Lina Bo Bardi em LATORRACA, 1999, p.27
} 
Ventilação e iluminação foram garantidas pela manutenção dos sheds e muxarabis, e pela colocação de telhas de vidro. No espaço de estar foram colocados ainda uma lareira e o Rio São Francisco, um espelho d'água de traçado espontâneo determinado livremente durante a obra.

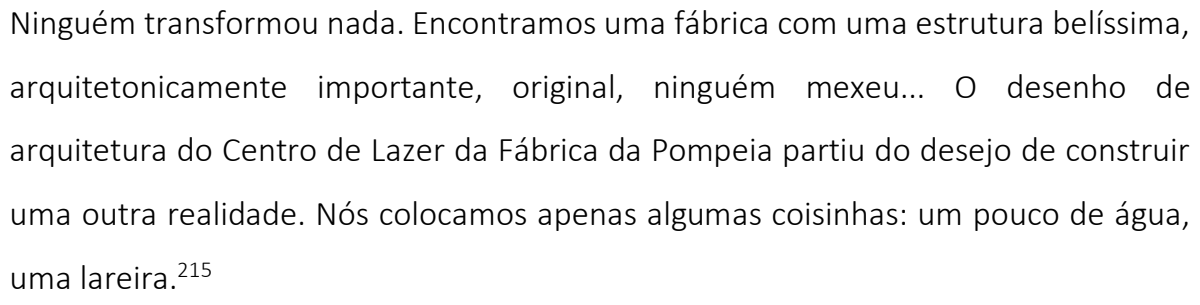

O teatro ocupa o único galpão cuja iluminação ocorre por lanternim ao invés dos sheds, mantendo a característica da construção industrial já existente antes da reforma. No espaço do foyer as telhas originais foram substituídas por telhas de vidro, e o piso por paralelepípedo como continuação da rua principal. A sala de teatro constitui-se por um palco central cuja plateia se distribui em dois blocos opostos de cadeiras.

Para a construção dos novos blocos que abrigam o conjunto esportivo, o apoio e a caixa d'água, a decisão pelos volumes verticais deveu-se ao contraste que estabeleceriam com os volumes horizontais da fábrica e como forma de inserção do conjunto do SESC à paisagem da cidade que se formava a sua volta. As duas torres que formam este conjunto foram interligadas por passarelas que se projetam sobre uma área non aedificandi por onde passa o Córrego das Águas Pretas, sobre o qual segue um deck de madeira que conforma uma "praia".

Ainda sobre as torres, as aberturas do bloco de apoio são retangulares e dispostas de forma compositiva não lógica, as quais estão localizadas em alturas diversas em cada trecho do edifício, fazendo com que a percepção interna e externa da entrada de luz se dê de maneira variada. As aberturas do bloco esportivo, por sua vez, foram posicionadas de forma regular, mas são literalmente buracos abertos nas paredes.

215 Lina em LATORRACA,1999, p. 27 


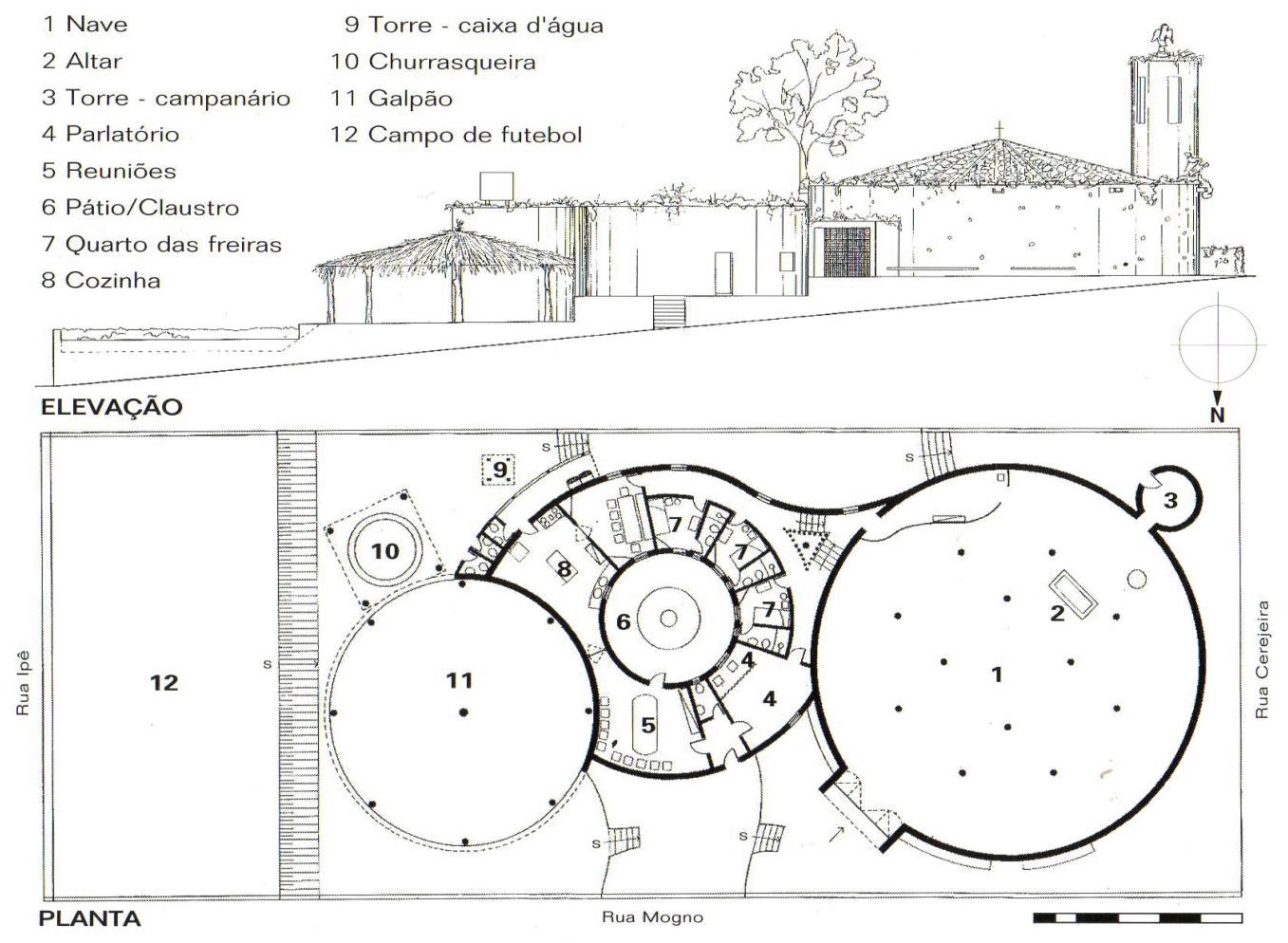

FIG.96 Planta e Elevação da Igreja do Espírito Santo do Cerrado Fonte: FERRAZ, 1993, p.221
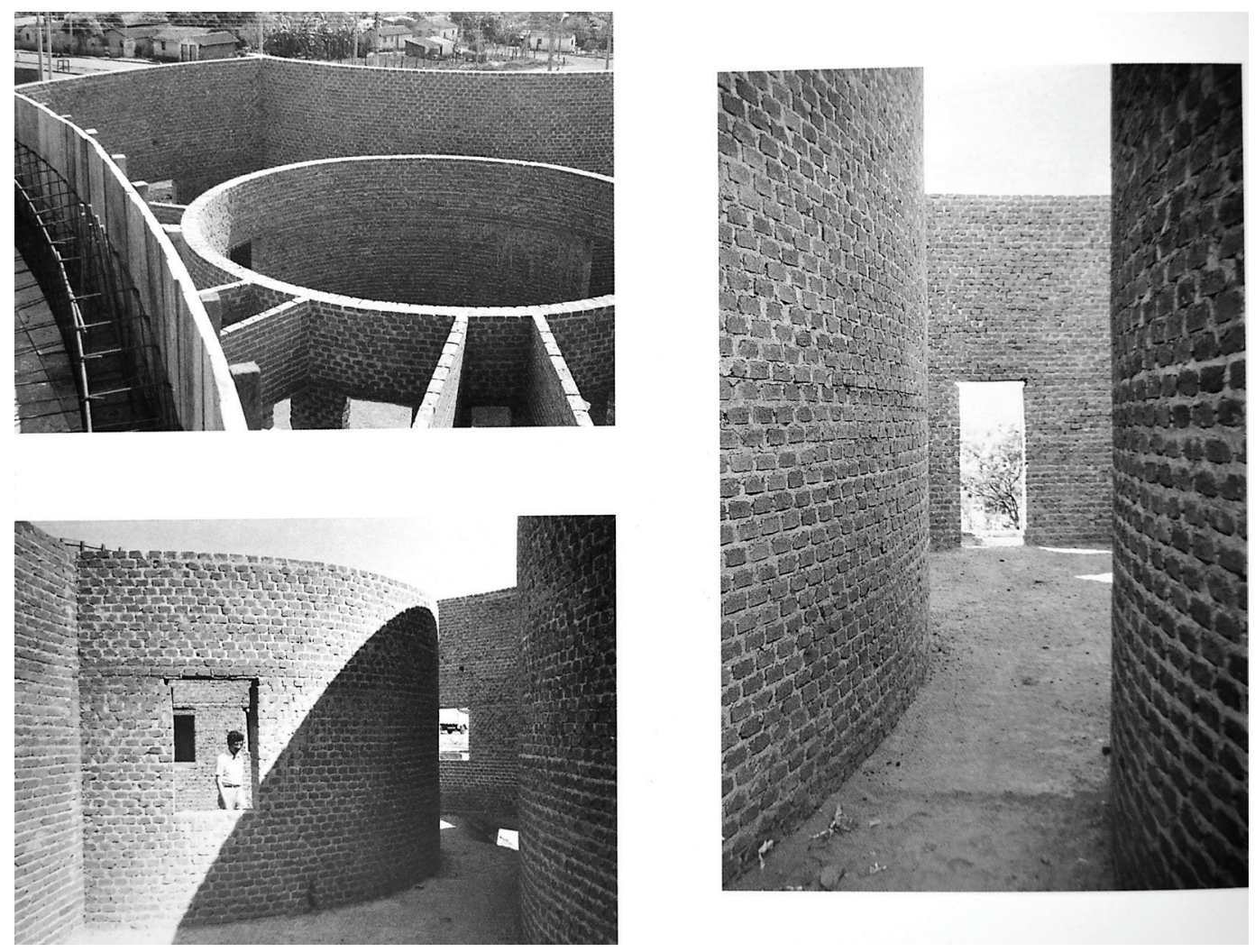

FIG.97-99 Paredes curvas da igreja em construção Fonte: FERRAZ, 1999 


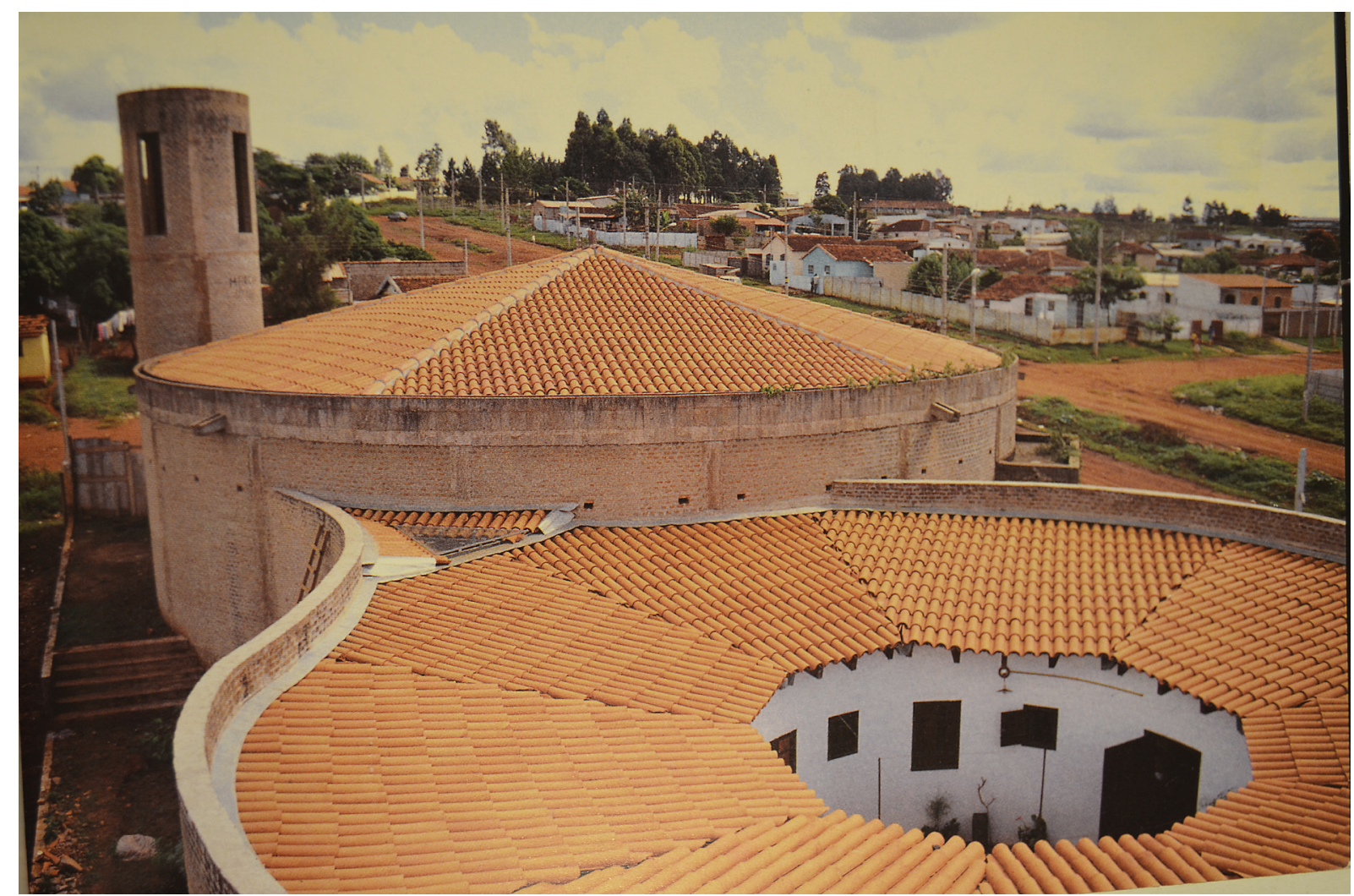

FIG.100 Vista dos telhados da igreja

Fonte: FERRAZ, 1999

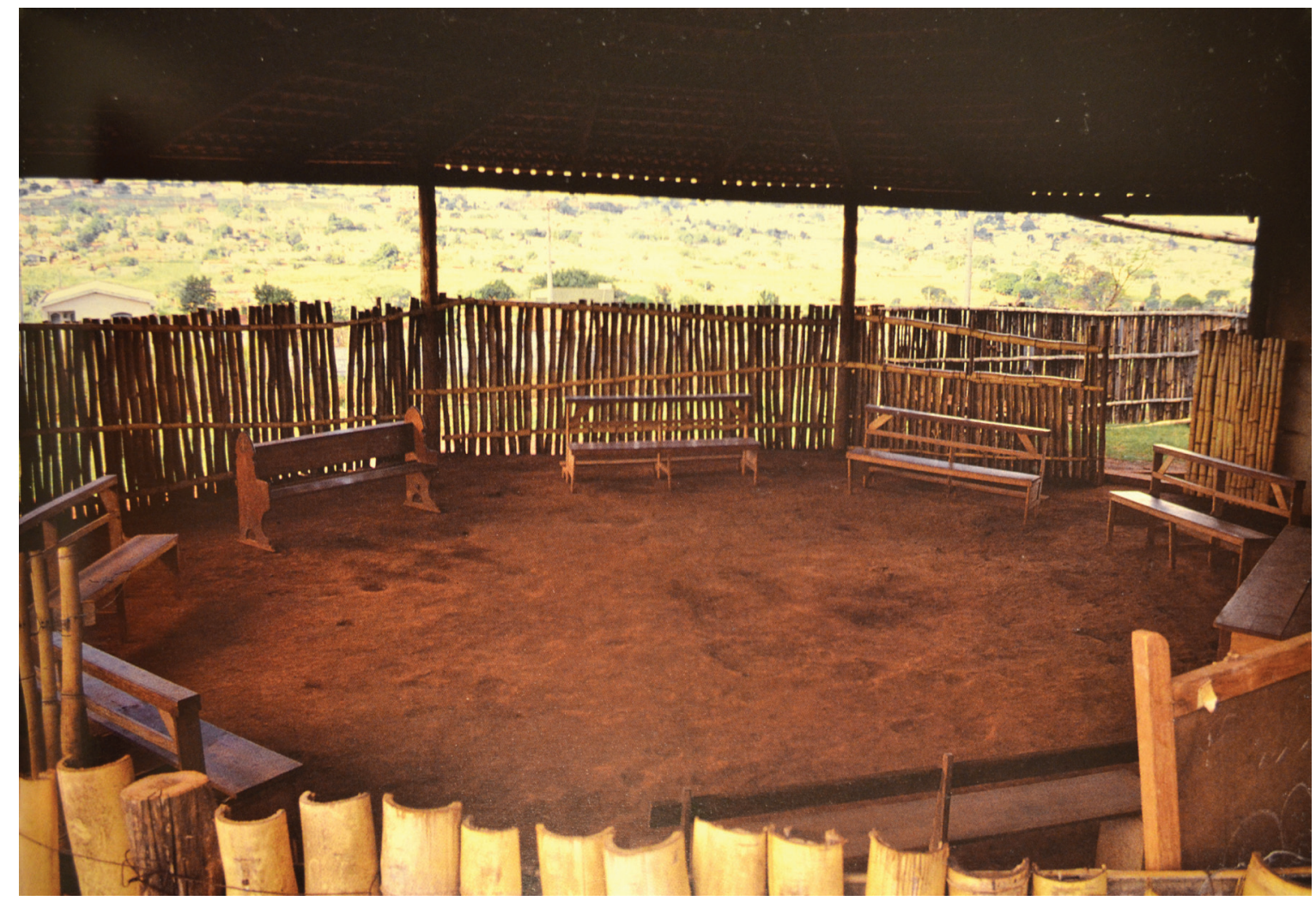

FIG.101 Centro comunitário com piso em terra batida e fechamento em bambu Fonte: FERRAZ, 1993, p.213 


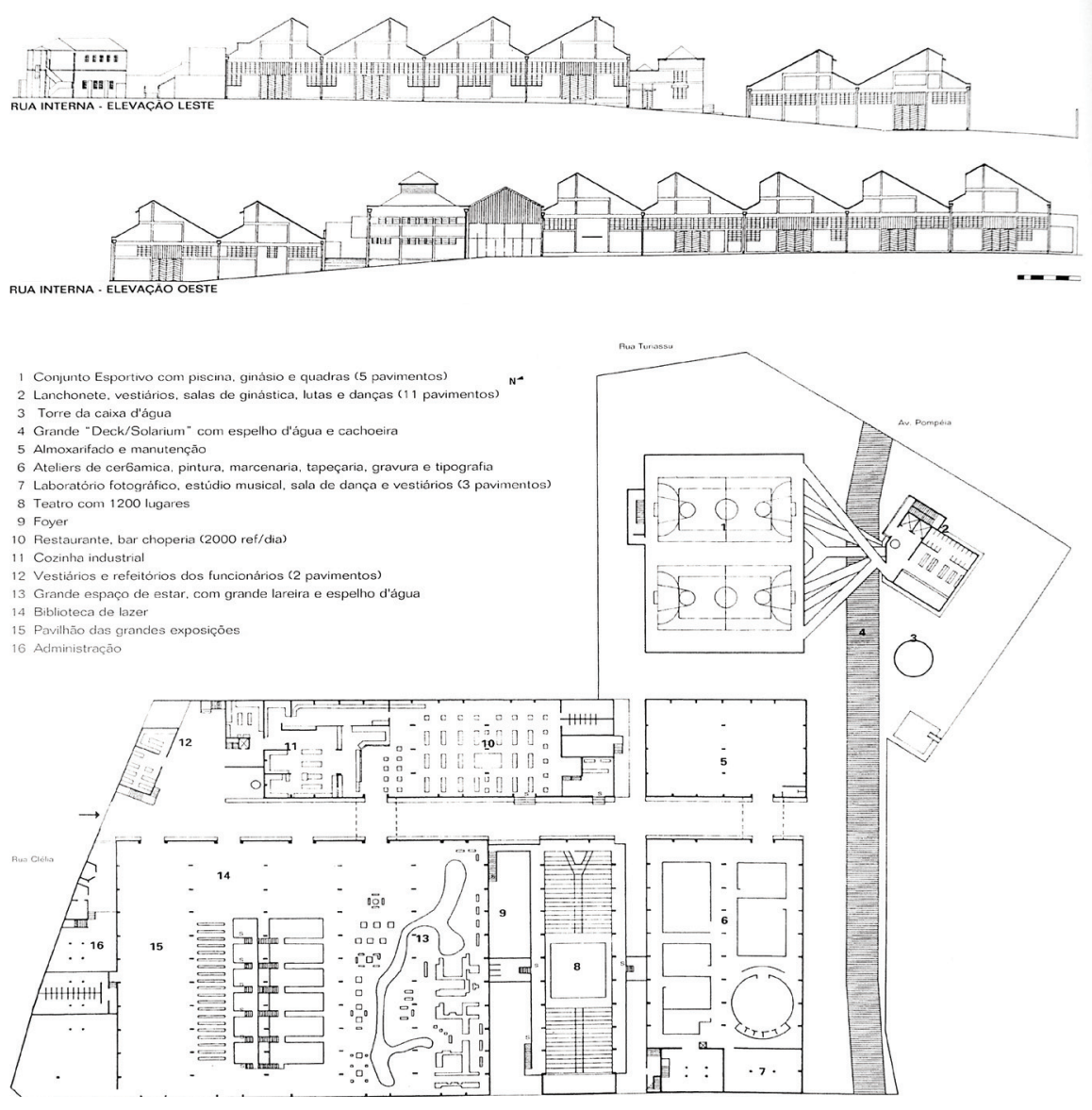

FIG.102 Planta e Cortes do SESC Pompéia Fonte: FERRAZ, 1993, p.222

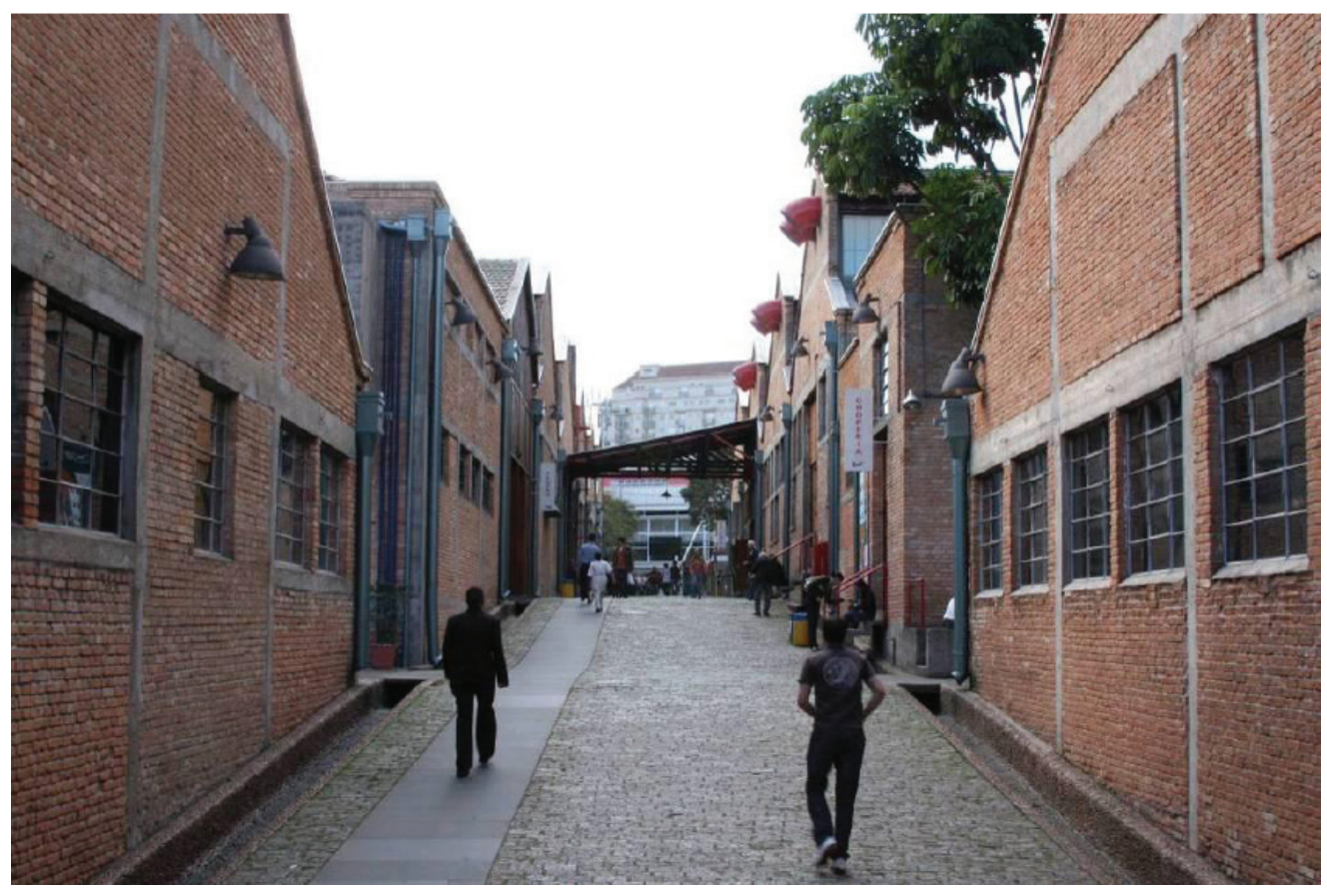

FIG.103 Rua central de acesso ao conjunto do SESC Pompeia Nota-se opiso em blocos e as calhas laterais de seixos rolados. Fonte: SUZUKI, 2010, p.145 

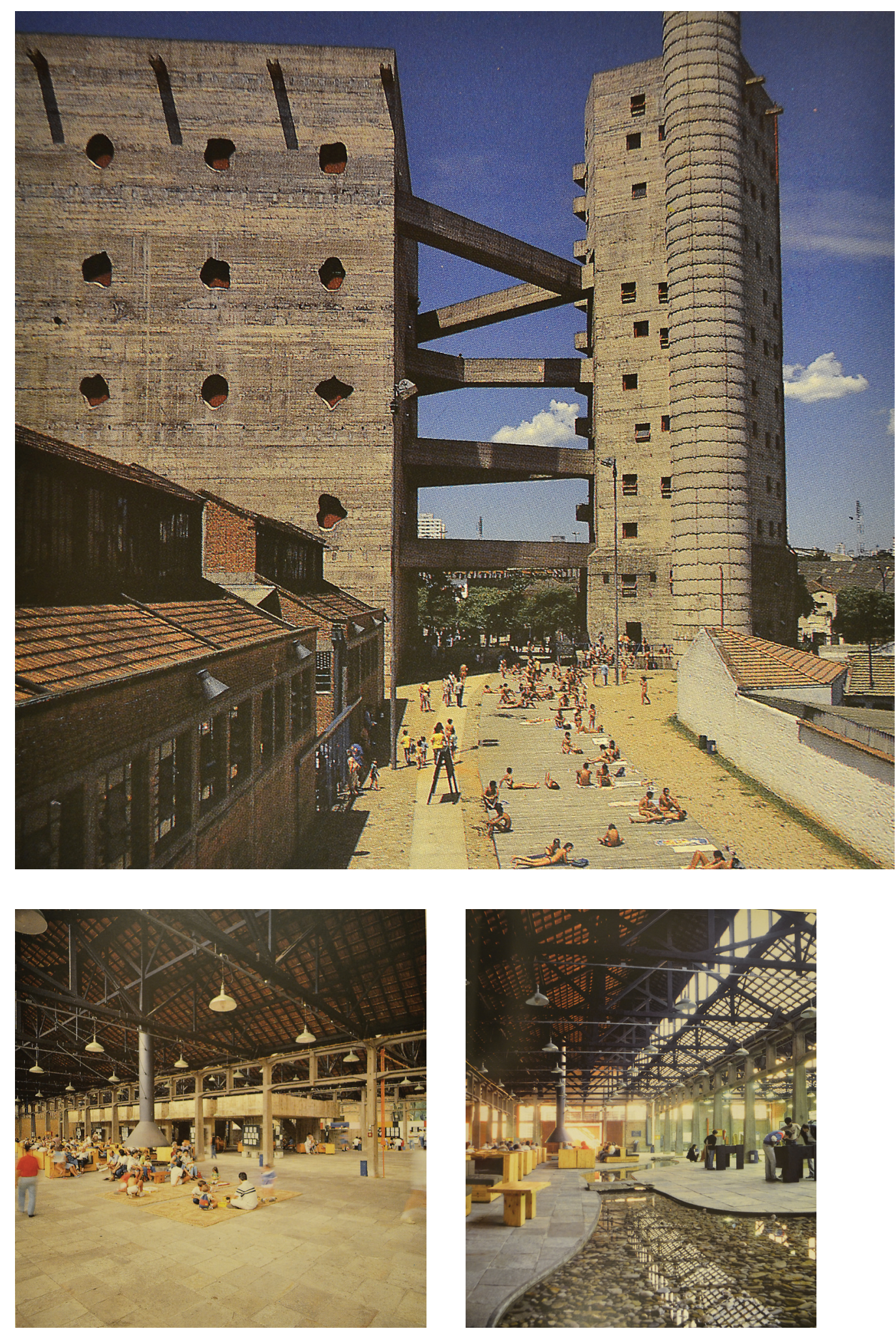

FIG.104 "Praia" e blocos esportivos ao fundo com suas janela buraco Fonte: FERRAZ, 1993, p.230

FIG.105 Galpão com atividades em diferentes níveis Fonte: OLIVEIRA, 2014, p.134

FIG.106 "Rio São Francisco" e lareira ao fundo Fonte: LATORRACA, 1999, p.79 


\subsection{PRESENTE HISTÓRICO}

Lina sempre trabalhou com o presente, com o que estava acontecendo a sua volta e com o que tinha em suas mãos. Um presente consciente de sua história e formado por ela como um processo contínuo.

\footnotetext{
Por "continuidade histórica" deveríamos entender uma repetição de sequências e atividades aprendidas e herdadas tradicionalmente e não uma operação reflexiva de cada fase sobre a precedente. O termo história, tal como utiliza Lina, é sinônimo de tempo, de um passado vivo que está incidindo diretamente sobre nós e incitando-nos à ação, não tendo nada a ver com aquela disciplina que organiza e arquiva o passado. 216
}

E o tempo trabalhado por Lina era um tempo não linear, cujos elementos se misturavam. $O$ tempo da memória do homem está presente em seus projetos. É a concisão apontada por Oliveira (2006) que fez com que soluções e materiais fossem utilizadas repetidamente, em diversos projetos da arquiteta, conformando diferentes combinações e eliminando assim a noção temporal de execução dessas obras. ${ }^{217}$ Tal postura se assemelha em grande parte à consideração feita por Pagano (1935) sobre a questão do tempo nas construções rurais italianas:

Ma quello che più risalta nella costruzione rurale è la sua astrazione da un tempo cronologicamente definito secondo attributi stilistici. La costruzione rurale è un "fatto" architettonico risolto con finalità puramente tecniche e utilitarie, con un procedimento spontaneo, esente da ogni principio teorico. La assenza constante di

\footnotetext{
216 OLIVEIRA, Olívia. Lina Bo Bardi: Sutis substâncias da arquitetura. São Paulo, Barcelona: Romano Guerra, Gustavo Gilli, 2006. p.20

${ }^{217}$ A autora se utiliza deste fato para em seu estudo fazer uma leitura simultânea de toda a obra através desses elementos reconhecíveis.
} 
qualsiasi preconcetto stilistico ha data nei secoli a questa manifestazione edilizia un carattere inconfondibile di ingenuità, di freschezza, di sincerità. ${ }^{218}$

Esse conceito de tempo não linear pode ser observado, por exemplo, na Casa de Vidro, onde objetos coletados ao longo dos anos em diversos lugares foram se somando e, sem conflito, fizeram parte do mesmo espaço moderno. É o registro da construção da história como contínua transformação. “Acreditamos necessário restabelecer a presença do homem na obra de arte, restabelecendo as dimensões humanas depois das abstrações idealísticas." 219

Azevedo (1995) propõe-se a discutir esse tema através do desenvolvimento de três pontos: a crescente valorização do patrimônio, o aspecto cultural empreendido por Lina, e a sistematização da visão social e estética da arquiteta. "O ato do restauro procura evitar o caminho natural do mundo das coisas: a deterioração, a destruição. É, no entanto a manifestação da passagem do tempo, o envelhecimento que atribui às coisas tangíveis o seu caráter de testemunhas, a sua importância enquanto memória de referências culturais."220

Assim, o chamado presente histórico para Lina Bo Bardi vem dessa noção da construção do presente como continuidade da história a partir de aspectos culturais, como explicou a arquiteta:

\footnotetext{
O passado, visto como presente histórico, é ainda vivo, é um presente que ajuda a evitar as várias arapucas. Diante do presente histórico, nossa tarefa é forjar um outro presente, "verdadeiro", e para isso é necessário não um conhecimento profundo de especialista, mas uma capacidade de entender historicamente o passado, saber distinguir o que irá servir para novas situações de hoje que se apresentam a vocês, e tudo isso não se aprende somente nos livros. ${ }^{221}$
}

A continuidade histórica dos projetos de Lina se estende na relação do projeto com a cidade. Isso não só na implantação da arquitetura e no cuidado com seus acessos e percursos, mas também na preocupação com a manutenção da relação humana cultivada anteriormente no local de intervenção, como ocorre de forma bastante evidente nos projetos da Igreja do Espírito Santo do Cerrado, no SESC Pompéia.

\footnotetext{
218 PAGANO, 1935, p.10-11

219 Folheto de inauguração do MAMB. In: FERRAZ, 1993, p.139

220 AZEVEDO, 1995, p.88

221 Transcrição de trecho da conferência em homenagem a Lina Bo Bardi na Faculdade de Arquitetura e Urbanismo da Universidade de São Paulo, em 1989. RUBINO, Silvana; GRINOVER, Marina (org). Lina por escrito: textos escolhidos de Lina Bo Bardi. São Paulo: Cosac Nayfi, 2009, p.165
} 
Para a arquiteta, a intervenção nas cidades deveria se pautar nos avanços da tecnologia e ao mesmo tempo levar em conta os valores culturais sedimentados.

\footnotetext{
Lina definirá o arquiteto como um misto de conhecedor das questões técnicas sobre a cidade e de alguém que possui a capacidade de ler, de codificar estruturas culturais intrínsecas que se estabelecem diferentemente em cada espaço urbano, constatadas pela vivência experimentada sobre o mesmo.

$(\ldots)$

Assim, entendendo a tradição cultural como viva e dinâmica, passível de transformações, é que Lina irá propor uma ação sobre a mesma, mais com o sentido de transformá-la do que de conservá-la. ${ }^{222}$
}

\section{IGREJA DO ESPÍRITO SANTO CERRADO}

O entendimento do presente como um processo contínuo dos acontecimentos do passado, responsáveis pela formação da história e da memória de um povo, carregou para a prática da intervenção em espaços pré-existentes o dado da permanência das marcas do tempo aliada à adequação necessária à sobrevida das construções de forma compatível com a evolução da cultura tradicional local. Este conceito, na obra de Lina Bo Bardi, é aplicado também à preservação dos materias e das técnicas de construção como forma de afirmação da cultura de determinada população.

Contrária a postura de Violet-Le-Duc do retorno ao estado original da obra, Lina operou segundo os conceitos do restauro crítico ${ }^{223}$ em suas obras, defendendo um funcionalismo que considerava também a memória coletiva e o modo de vida característico do lugar.

A ideia de restauro possuía para Lina Bo Bardi um sentido ampliado. Não se referia estritamente a preservação de arquiteturas já construídas e que se encontrassem em estágio de deterioração física, mas a conceitos construtivos vernaculares ameaçados de se reproduzirem. O projeto da Capela de Ibiúna (SP) e da Igreja do Espírito Santo do Cerrado (MG). São restauros do conceito de construir vernacular: estrutura de rústicos troncos de madeira, palha, barro, tijolos de barro, e construção realizada pela comunidade em questão. A construção em si, nestes casos, funciona como

\footnotetext{
222 PEREIRA, 2007, p.79

223 "A arquiteta se fundamentou no método da restauração crítica, desenvolvida na Itália por Carlo Scarpa e Franco Albini. Esse modelo de restauração trabalha o respeito pela tradição e ao mesmo tempo reconhece o valor funcional da realidade." (OLIVEIRA,2007,p.33)
} 
mecanismo de preservação de memórias construtivas vernaculares que tendem a desaparecer. ${ }^{224}$

No caso da igreja, o presente histórico esteve na manutenção da relação do povo com o lugar transformando apenas o espaço físico de suas relações.

\section{SESC POMPÉIA}

Na Fábrica da Pompéia, o cuidado com os materiais esteve presente tanto no que era antigo como no que era novo, e fazendo as intervenções a sua maneira, a arquiteta foi capaz de transformar um galpão fabril em um espaço de convivência humana.

Para este projeto Lina reuniu elementos de memória em diversas escalas, como por exemplo remetendo a torre esportiva aos fortes coloniais, utilizando signos regionais populares nos objetos projetados para o conjunto, ou ainda "reconstruindo" a chaminé da fábrica com a torre cilíndrica de $75 \mathrm{~m}$ de altura para a caixa d'água.

A manutenção da estrutura de Hennebique ${ }^{225}$ foi o primeiro passo da obra. Em seguida foi retirado o reboco externo das paredes a fim de revelar os tijolos posicionados de forma racional. As portas em madeira de lei também foram preservadas, assim como as telhas originais que foram limpas e recolocadas. O eixo principal de circulação foi mantido como uma rua, como se convidasse a cidade a entrar no conjunto, remetendo às ruas e vielas de São Paulo e suas vilas operárias.

Ao assumir a manutenção do galpão industrial antigo, Lina assumiu também a possibilidade do permanente convívio dessa construção com a cidade que cresceria a sua volta. A circulação central do conjunto industrial existente, que já se mostrava no primeiro desenho de Lina, foi liberada como uma rua, como um eixo urbano ${ }^{226}$, que sobrepunha escalas, trazia a cidade para o edifício e o edifício como continuação desta cidade. A construção das torres verticais também se mostrou como um ícone para o desejo de inserção do conjunto na paisagem urbana. Como destaca Rosseti (2006,p.6), "os projetos de Lina Bo Bardi transformam o sentido dos lugares em referências urbanas efetivas. Com isso, a arquiteta consegue determinar a qualidade das relações do projeto com a trama e com a vitalidade da cidade."

\footnotetext{
${ }^{224}$ AZEVEDO, 1995, p.94-95

225 François Hennebique (1842-1921), engenheiro francês

${ }^{226}$ SUZUKI,2010,p.144
} 


\subsection{O SABER FAZER}

Ao crer nas possibilidades técnicas que a modernidade poderia trazer como evolução aliada a uma tradição cultural construtiva, Lina era capaz de incorporar a cultura tradicional de forma reflexiva ao contexto moderno estabelecendo um diálogo entre essas duas frentes e consolidando o papel do arquiteto como intérprete da cultura. ${ }^{227}$

Recusando a ideia de espaço abstrato, genérico, slogan do Modernismo, a arquiteta propôs o espaço à escala da situação antropológica. Talvez seja esta a característica mais marcante na abordagem da arquiteta: - a ausência de regras fixas na resolução do projeto the garantia um elevado grau de liberdade de escolha. A solução praticamente resultava dos dados do problema ${ }^{228}$

A íntima ligação de Lina com a cultura popular através do olhar apurado Ihe indicava as possibilidades de um fazer arquitetônico munido das qualidades inventivas observadas, distante de uma estética idealizada, reconhecendo a funcionalidade do objeto popular "em concordância com os postulados do design moderno, portanto distante da gratuidade dos adereços burgueses. Uma arquitetura francamente afetiva e radicalmente seca." 229

\section{ARQUITETURA POBRE}

O saber fazer também esteve ligado à prática profissional do arquiteto, ciente de suas responsabilidades e da importância de seu comprometimento com a construção. A aproximação com a obra, segundo Oliveira (2006), ocorre como forma de barrar a idealização do tempo praticada pela

\footnotetext{
${ }^{227}$ AZEVEDO, 1995, p.80

228 AZEVEDO, 1995, p.82

229 JORGE, 1999, p.99
} 
arquitetura projetiva, de forma que todas as limitações e vantagens no decorrer da construção foram incorporadas à concepção do edifício. "Uma atitude construtiva que se relaciona ao "bem fazer", também presente no labor popular e nas atividades tradicionais - tecer, arar, caçar, cozinhar, curar, cantar, narrar, dançar, etc - em cuja execução jamais intervém a ideação da atividade." 230

Neste sentido, a presença do fazer popular estava marcado não só pela interpretação da própria arquiteta a partir de suas pesquisas e observações em períodos anteriores, mas também no contato direto desse saber fazer popular com a obra através do trabalho dos operários.

\footnotetext{
Se objetos de fatura popular faziam parte da desordem do escritório de obra, como lembranças de determinada sensibilidade estética que Lina queria manter viva, foi a presença mesma do escritório na obra - o entendimento da arquitetura como construção, o detalhamento 'artesanal' -, o que destacou o projeto do Sesc-Pompéia da produção brasileira dos anos 70.231
}

Assim como Pagano, Lina acreditava no instinto construtivo e na evolução técnica de seus produtos através de um conhecimento evoluído por gerações. Sendo assim, as construções populares não caracterizariam manifestações espontâneas, mas ações conscientes de suas possibilidades e limitações. E este foi um importante aprendizado carregado por Lina para seus projetos.

(...) Aproveitei ao máximo a experiência de cinco anos passados no Nordeste, a lição da experiência popular, não como romantismo folclórico mas como experiência de simplificação. Através de uma experiência popular cheguei àquilo que poderia chamar de Arquitetura Pobre. Insisto, não do ponto de vista ético. ${ }^{232}$

Sobre a construção do conjunto para o SESC Pompéia Lina foi enfática ao dizer que a "ideia inicial de recuperação do dito Conjunto foi a de "Arquitetura Pobre", isto é, não no sentido de indigência, mas no sentido artesanal que exprime Comunicação e Dignidade máximas através dos menores e humildes meios." 233

\section{IGREJA DO ESPIRITO SANTO}

A construção da Igreja do Espírito Santo, iniciada somente em 1979, foi viabilizada pela doação dos projetos de Lina Bo Bardi e Rodolfo Ochoa, pela utilização de materiais locais, doados ou

\footnotetext{
230 OLIVEIRA,2006, p.31-32

231 BASTOS;ZEIN,2010, p.209

232 Anotações pessoais de Lina sobre o MASP. FERRAZ, 1993, p.100

233 Lina Bo bardi em LATORRACA,1999,p.27
} 
reaproveitados de demolições, pela ajuda financeira da organização alemã Adveniat ${ }^{234}$ e sobretudo, pela mobilização da comunidade para a construção deste projeto através dos mutirões.

Para as alvenarias curvas foram eleitos os tijolos de barro com pilares e vigas de concreto armado, enquanto as coberturas circulares eram de telha canal estruturadas por pilares de madeira local (aroeira). A vedação, do também circular centro comunitário, foi composta por bambus de meia altura que lembram uma paliçada indígena.

As formas curvas do projeto, embora tenham causado um espanto inicial como relata Vicente de Paula Mariano, um dos trabalhadores contratados da obra, em entrevista a Lazzarin (2015, p.69), não se apresentaram como um entrave diante da capacidade técnica da tradição construtiva popular de criar soluções diante da necessidade carregada pelo carpinteiro.

(...) Como é que você vai fazer redondo? Como é que você vai aprumar o tijolo redondo? (...) E aí eu te pergunto. Como é que eu fiz? Sabe que é que eu fiz? Fui lá no centro, assentei, peguei um pau, finqui o pau com três metros de altura, aprumei ele bem aprumadinho nos quatro lados dele, peguei uma corda (...) e pus assim o pau e eu pus no pau tipo duma argola... (...) Então o cara assentava três tijolos e espichava e dava o prumo. Aí subia mais um pouquinho, assentava mais, espichava e... Pra não ficar você aprumando de tijolo em tijolo. (...) Pois é... E eu que inventei isso. Ai fui eu que inventei na época lá... Porque vou inventar porque senão nós vai ficar dez anos aqui assentando tijolo aqui, uai... ${ }^{235}$

Com a finalização das alvenarias, a solução definitiva para a cobertura do conjunto foi determinada por Lina Bo Bardi após uma visita à obra em $1980^{236}$. Entre diversas possibilidades elaboradas desde o início da concepção do projeto em 1976, Lina detalhou aquela que mais se adequava a situação encontrada na construção, e os desenhos enviados à obra foram acompanhados de instruções de montagem do conjunto. A cobertura em telha canal, disposta sobre uma estrutura em aroeira, recebeu um recorte triangular acima do altar cuja vedação foi feita com telhas translúcidas, permitindo a entrada de iluminação natural.

Em 1981 a obra encontrava-se em fase de acabamentos. Na cota mais alta, a construção destinada à igreja receberia os visitantes, com um piso de pedra Goiás, a partir do Norte com uma porta de madeira

\footnotetext{
234 Organização católica criada em 1961 na Alemanha, na cidade de Essen, que tem como objetivo auxiliar os pobres da América Latina através da igreja

235 Entrevista do carpinteiro Vicente de Paula Mariano concedida a Lazzarin (2015, p.67)

236 LAZZARIN, 2015, p.77-81
} 
treliçada. Em todo o perímetro das paredes de alvenaria de tijolos de barro estavam distribuídas aberturas que auxiliariam tanto na iluminação quanto na ventilação 237 .

O uso de materiais simples e a adoção de um sistema de produção ligado diretamente ao povo praticados na construção da Igreja do Espírito Santo do Cerrado fizeram parte do posicionamento político e construtivo adotado por Lina, reforçando os argumentos de seu discurso após a desilusão diante da utopia moderna ocasionada pelas consequências do golpe de 1964 .

\section{SESC POMPÉIA}

No SESC Pompéia, entre 1977 a 1986, projeto e obra andaram juntos em duas fases de desenvolvimento. A primeira, de 1977 a 1982 foi dedicada à reforma da antiga fábrica para abrigar o conjunto de atividades gerais, administração e restaurante. Na segunda fase, de 1982 a 1986 foi realizada a construção do novo conjunto de torres verticais destinados às atividades esportivas, apoio e à caixa d'água. No decorrer de todo o tempo de obra, Lina esteve atenta a todos os detalhes, desde os cuidados com o projeto e a obra, até o desenvolvimento de mobiliário e de detalhes de pintura e azulejo desenvolvidos por artistas convidados.

Durante nove anos (1977 a 1986), desenvolvemos com Lina o projeto do SESCPompéia, numa atividade diária em meio ao canteiro de obras: acompanhamento dos trabalhos, experimentações in loco e grande envolvimento de técnicos, artistas e, sobretudo, operários. Esta postura foi, também, uma verdadeira revolução no "modus operandi" da prática arquitetônica vigente. Tínhamos um escritório dentro da obra; o projeto e o programa eram formulados como em um amálgama, juntos e indissociáveis; ou seja, a barreira que separava o virtual do real não existia. Era arquitetura de obra feita, experimentada em todos os detalhes. ${ }^{238}$

Para a caixa d'água, por exemplo, Lina tomou como referência a textura do concreto das torres da cidade satélite, de Barragán. ${ }^{239}$ Tal textura dos anéis de concreto foi conseguida com a utilização sacos de estopa presos às formas que ao serem soltos permitiam que o concreto escorresse. $O$ piso do galpão dos ateliês foi composto por placas de concreto salpicadas de seixos de rios, cuja quantidade foi

\footnotetext{
${ }^{237}$ Porém, em uma intervenção posterior essas aberturas foram fechadas e as paredes rebocadas e pintadas de branco no interior da construção.

238 FERRAZ, Marcelo. Numa velha fábrica de tambores. SESC-Pompéia comemora 25 anos.Minha Cidade, São Paulo, 08.093, Vitruvius, abr 2008 <http://www.vitruvius.com.br/revistas/read/minhacidade/08.093/1897> Consultado em 10 de julho 2013

239 OLIVEIRA,2007,p.94
} 
medida pelos pedreiros durante o preparo do concreto. A marca dos operários também esteve na composição aleatória dos azulejos de Rubens Gerchman, e nos objetos que compõem a placa de comunicação do restaurante, esculpidos em madeira por um carpinteiro.

Sendo o projeto executivo realizado no canteiro de obras, foram permitidas muitas decisões, principalmente de acabamentos, que não seriam possíveis no projeto executivo entregue num só pacote para o cliente. As divergências, erros de percurso, caminhos possíveis que existem no cotidiano faziam parte do processo de trabalho. Lina borrou nesse momento a fronteira entre o erudito e o popular relacionando artistas, técnicos e operários, situação de troca que se traduziu numa arquitetura simples, clara, repleta de poesia. Raízes de toda a sua história ligada à condição estrangeira e ao esforço de integração no novo contexto cultural, a arquiteta teve a capacidade de produzir uma nova realidade, através de uma releitura de valores. (...) Durante a realização da obra, seguia os experimentos 'in loco'. Nesses experimentos o espaço obteve soluções que carregavam um pouco da cultura dos operários, incorrendo valores do povo, criando identidade. ${ }^{240}$

A preservação da memória e a sequência permitida a evolução do saber fazer da tradição construtiva foram aplicados através do uso dos conhecimentos e da materialidade brasileira.

A calçada externa, o passeio público, que contorna o SESC-Pompéia, os condutores de águas pluviais que ladeiam o passeio de paralelepípedos entre os galpões da antiga fábrica, são pacientemente revestidos de seixos rolados, numa tarefa artesanal, onde a marca da mão laboriosa e paciente se expressa, valendo-se dessas "semipreciosidades" naturais. Assim também é realizado o mosaico de cacos cerâmicos coloridos dos banheiros do SESC-Pompéia. Constrói-se, então, uma espécie de bijuteria arquitetônica, relicário de restos e gestos próprios de uma arquitetura que se faz fazendo. 241

\footnotetext{
240 OLIVEIRA,2007,p.42

241 JORGE, 1999, 106
} 

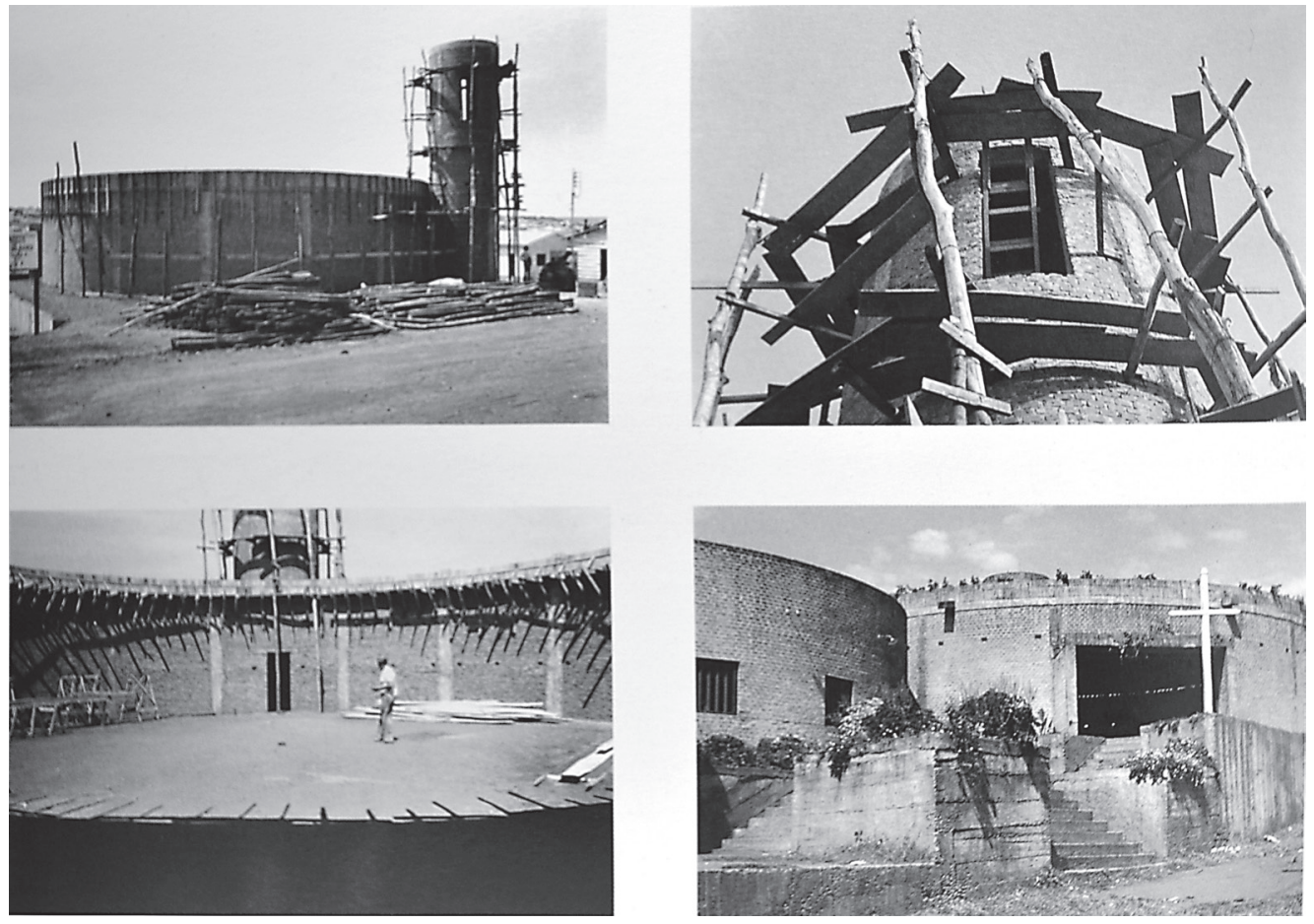

FIG.107-110 Igreja do Espírito Santo do Cerrado em construção Fonte: FERRAZ, 1999 


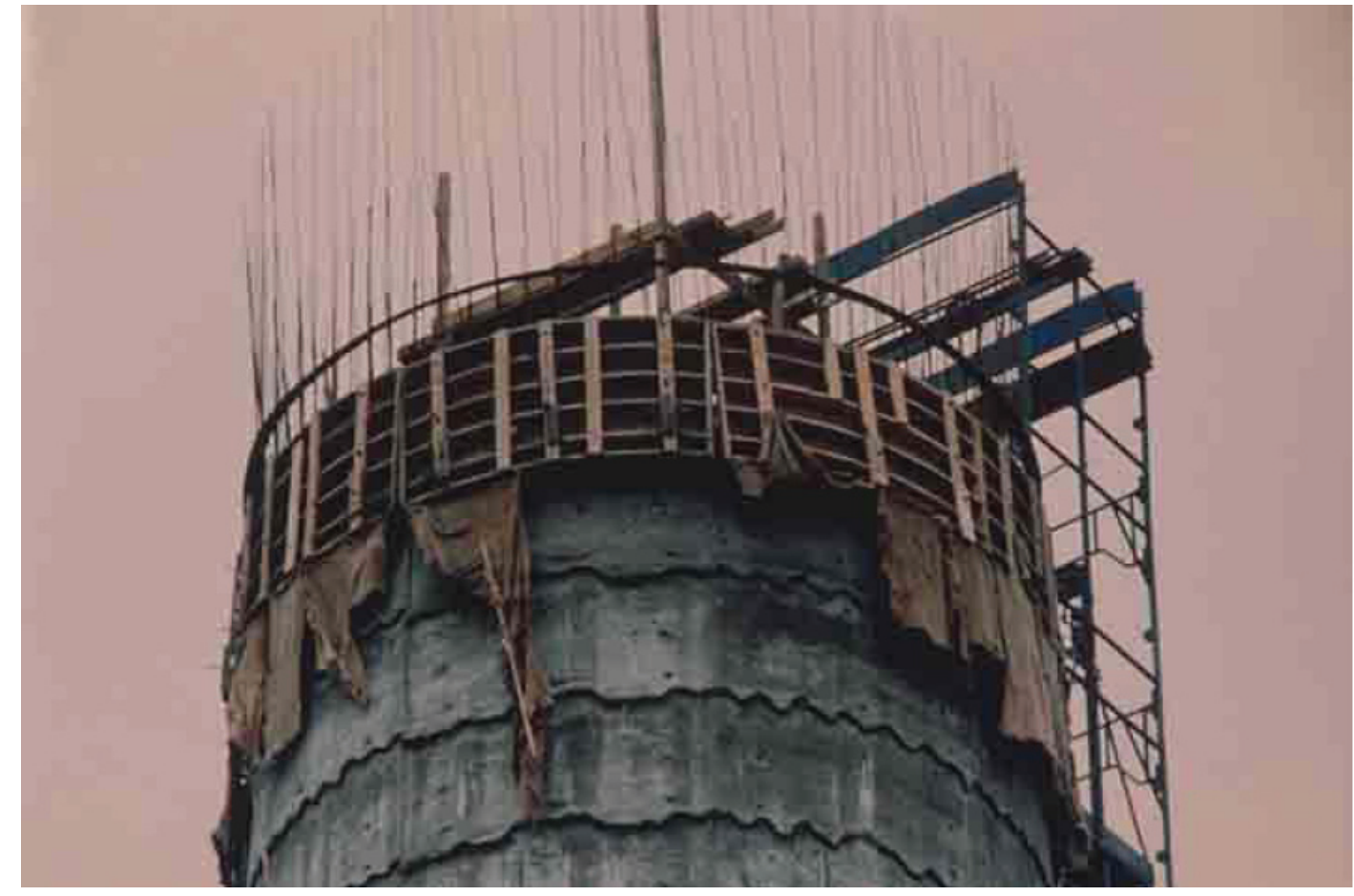

FIG.111 Detalhe da construção da caixa d'água do SESC Pompéia Fonte: OLIVEIRA, 2007, p.95

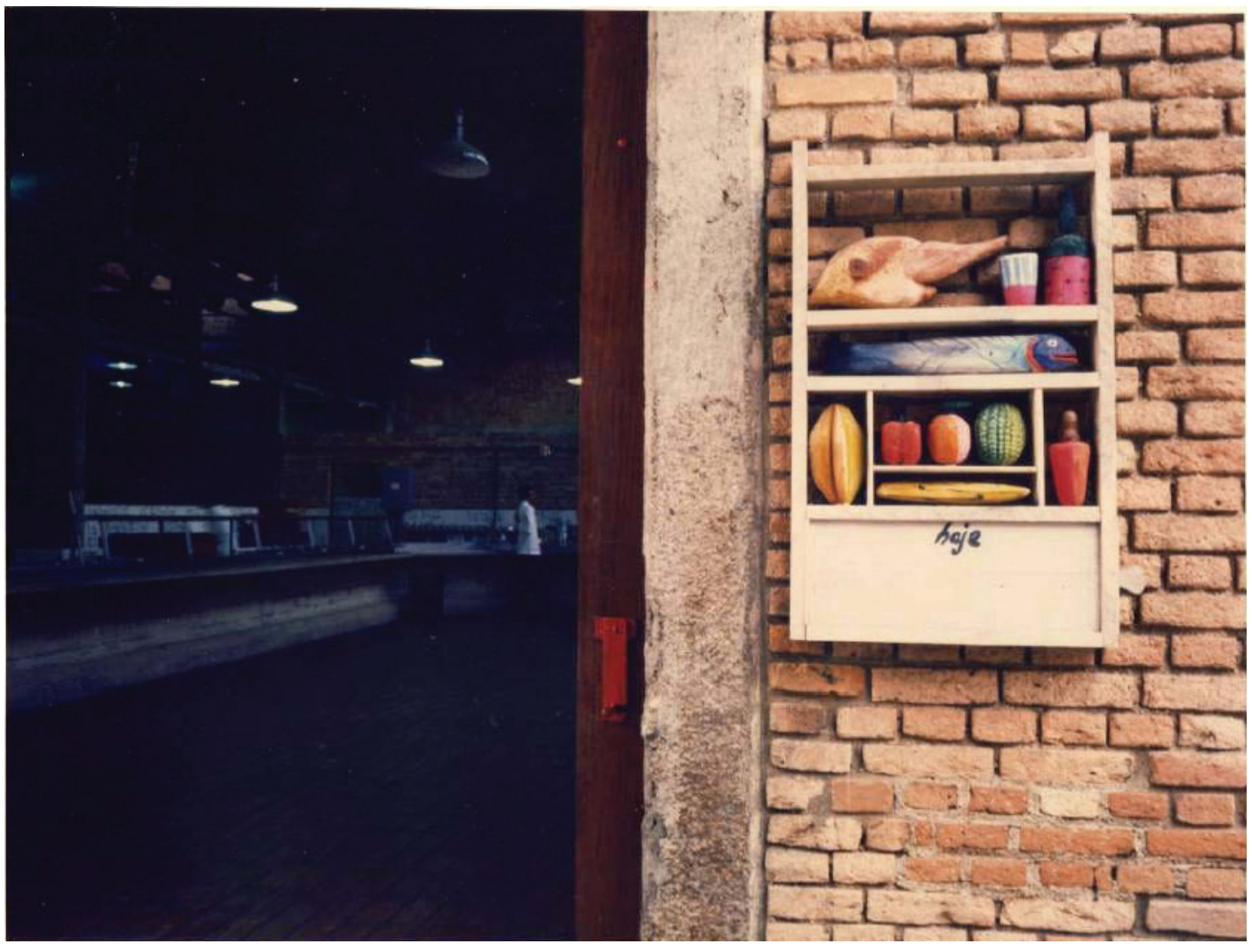

FIG.112 Placa do restaurante desenhada por Lina e executada pelo marceneiro da obra Fonte: OLIVEIRA, 2007, p.77 



\section{CONSIDERAÇÕES FINAIS}

A questão da cultura popular na obra de Lina Bo Bardi alcança uma dimensão mais profunda quando olhamos para o seu processo de formulação desde o período na Itália. Percebemos como o conceito de apropriação do espírito das "artes menores" passa, ao longo do tempo, pela avaliação de diversas teorias e vertentes ideológicas que procuraram respostas para a modernidade além dos estudos da academia. A ideia moderna da busca por um "novo homem" carregou como principal fundamento a noção da necessidade da elaboração de um racionalismo que libertasse qualquer produção artística do academicismo estagnador a que estava submetida a produção italiana.

Nesse sentido, os debates empreendidos através dos editoriais de arquitetura foram fundamentais para a formação do pensamento crítico de uma geração ao qual Lina Bo Bardi fazia parte. Ao participar ativamente desse cenário, a arquiteta pôde desenvolver seus próprios meios de leitura sobre a cultura popular e basear sua atuação a partir desses princípios. As interlocuções estabelecidas por Lina na Itália, de forma direta ou indireta, repercutiram na formação de seu olhar sobre a modernidade e sobre a relação da elaboração deste conceito com as questões reais enfrentadas pela sociedade italiana, dentro de um contexto de questionamentos ideológicos e de consequências drásticas de guerra.

Constatamos que, de seus aprendizados sobre a formação de uma modernidade nacional, um dos pontos mais notáveis reside na percepção do trabalho com a cultura popular a partir da apreensão de seus fundamentos metodológicos, uma vez que, como vemos enunciado por Pagano, é nessas civilizações que são encontradas as expressões mais verdadeiras de simplicidade e racionalidade para a solução de questões cotidianas. Também de Gio Ponti a arquiteta carregou essa noção através do trabalho com produtos de desenho industrial que tomavam como base a produção artesanal.

Após os acontecimentos da guerra, a mudança de Lina para o Brasil the dá um novo fôlego para trabalhar a partir desse olhar sobre a modernidade e sobre a cultura popular. Seus esforços em 
empreender no país um desenvolvimento técnico e estético para a produção industrial e arquitetônica manifesta-se em primeiro momento em suas pesquisas para a revista Habitat. Também é notável o empenho de Lina junto a Pietro Maria Bardi em introduzir uma cultura didática de convivência com a arte, tanto do público leigo em relação à cultura erudita, quanto do público intelectual em relação aos produtos das culturas populares arcaicas do país.

Contudo, o momento de maior representação desse esforço didático de intercâmbio de cultural e, sobretudo, de valorização de uma das expressões da cultura popular brasileira acontece no período em que a arquiteta passa na Bahia. A escolha pelo recorte da cultura africana como representante de uma cultura nacional, e a produção do sertão como representante de racionalidade e simplicidade produtiva repercute em ações como as atividades do MAMB e a proposta de uma escola de desenho industrial que seria capaz de integrar os conhecimentos de projetistas e executores.

Lina queria que o Brasil tivesse uma indústria a partir do seu artesanato, a partir das habilidades que estão na mão do povo, do olhar da gente, com originalidade.

Podia reinventar os talheres da gente comer, os pratos em que come, a camisa de vestir, o sapato. Havia toda uma possibilidade de que o mundo fosse refeito, o mundo do nosso consumo, como alguma coisa que tivesse ressonância em nosso coração. Lina era das pessoas que ajudava a gente a pensar nesse rumo, a buscar coisas nesse rumo, uma prosperidade que fosse de todos e uma beleza que fosse alcançável, atingível. $^{242}$

A partir de 1964, apesar da tomada do regime militar, e da consequente interrupção de seus trabalhos, a arquiteta passa a operar com mais vigor na esfera da produção de espaços críticos, que muitas vezes colocam em questionamento até mesmo os preceitos modernos de concepção da arquitetura.

Vemos através do estudo sobre os projetos para a Igreja do Espírito Santo do Cerrado e para o SESC Pompéia, presentes neste trabalho, o empenho vivaz da arquiteta de trazer à tona a noção da possibilidade de concepção de arquiteturas de qualidade e aderentes à vida de suas populações mesmo diante de quadros de dificuldades, como a falta de recursos materiais. Ou ainda, no caso do SESC Pompéia, a lição sobre a possibilidade do trabalho em conjunto para a produção de espaços reconhecíveis aos mais diversos tipos de pessoas.

242 Darcy Ribeiro em depoimento no filme "Lina Bo Bardi", de 1993 
Assim, o exercício do pensamento crítico sobre a história e a atenção às tradições e aos saberes de quem lida com as situações mais extremas, mostram-se como hipóteses comprovadas para a formação de uma modernidade acessível a todos.

Desse modo, através da interpretação de um pequeno fragmento de tantos outros possíveis acerca da questão da cultura popular como método, este breve estudo traz o alerta para a oportunidade de muitos outros desdobramentos acerca da questão da cultura popular na arquitetura, não só na obra de Lina Bo Bardi por meio da investigação sobre outros projetos, mas também na Itália em seu contexto de formação da modernidade, e também no Brasil, a partir de sua grande diversidade de expressões genuínas e cada vez mais ocultas pela lógica econômica da construção das cidades. 


\section{BIBLIOGRAFIA}

\section{TESES E DISSERTAÇÕES}

ALMEIDA, Eneida. O "construir no construído" na produção contemporânea: relações entre teoria e prática. São Paulo, FAUUSP, Tese de Doutorado, 2009

AZEVEDO, Mirandulina M. M. A experiência de Lina Bo Bardi no Brasil (1942-1992). São Paulo, FAAUSP, Dissertação de Mestrado, 1995

CAMPELLO, Maria de Fátima de M. Lina Bo Bardi: as moradias da alma. São Carlos, EESC-USP, dissertação de mestrado, 1997

GRINOVER, Marina Mange. Uma ideia de arquitetura: escritos de Lina Bo Bardi. São Paulo, FAUUSP, Dissertação de Mestrado, 2010

JORGE, Luís Antônio. O espaço seco - imaginário e poéticas da arquitetura moderna na América. São Paulo, FAUUSP, Tese de doutorado, 1999

LAZZARIN, Ariel L. A Igreja Divino Espírito Santo do Cerrado e suas alternativas à arquitetura brasileira. São Carlos, EESC-USP, dissertação de mestrado, 2015

MACHADO, Vanessa R. Dos "parangolés" ao "eat me: a gula ou a luxúria?". São Carlos, EESC-USP, tese de doutorado, 2014

OLIVEIRA, Liana Paula P. de. A capacidade de dizer não - Lina Bo Bardi e a fábrica da Pompéia. São Paulo, Universidade Presbiteriana Mackenzie, Dissertação de Mestrado, 2007

OLIVEIRA, Raíssa Pereira C. de O. Permanência e inovação: o antigo e o novo nos projetos urbanos de Lina Bo Bardi. São Paulo, FAUUSP, Dissertação de Mestrado, 2008

ROSSETTI, Eduardo P. Tensão moderno/popular em Lina Bo Bardi: nexos de arquitetura. Salvador, PPGAU-FAUFBA, dissertação de mestrado, 2002

RUBINO, Silvana Barbosa. Rotas da modernidade: trajetória, campo e história na atuação de Lina Bo Bardi, 1947-1968. Campinas, Universidade Estadual de Campinas, tese de doutorado, 2002.

STUCHI, Fabiana Terenzi. Revista Habitat: um olhar moderno sobre os anos 50 em São Paulo. São Paulo, FAUUSP, Dissertação de Mestrado, 2006

SUZUKI, Marcelo. Lina e Lú cio. São Carlos, EESC-USP, tese de doutorado, 2010 


\section{PERIÓDICOS}

ANELI, Renato. Ponderações sobre os relatos da trajetória de Lina Bo Bardi na Itália. In: Revista Pós. São Paulo: FAUUSP, 2010, no27

ARTE popular. Habitat, São Paulo, no5, out-dez 1951, p.55

BARDI, Lina Bo. Amazonas: o povo arquiteto. Habitat, São Paulo, no1, out-dez 1950, p.68-73

Artes Menores - Notas para criação de uma cadeira de Desenho Industrial. Ângulos, Salvador, n.16, dez.1960, p. 121-124 Apud. GRINOVER, Marina Mange. Uma ideia de arquitetura: escritos de Lina Bo Bardi. São Paulo, FAUUSP, Dissertação de Mestrado, 2010, p. 178-181

Bela criança. Habitat, São Paulo, no2, jan./ mar. 1951

. Desenho Industrial. Habitat, São Paulo, no5, out-dez 1951, p.62-63

. Do is o bjetos. Habitat, São Paulo, no5, out-dez 1951, p.64

. Um restaurante. Habitat, São Paulo, no2, jan-mar. 1951, p.39

BARDI, Pietro Maria. Para uma nova cultura do homem. Habitat, São Paulo, no2, jan-mar 1951, p.1

BELÉM . Habitat, São Paulo, no9, out-dez 1952, p.47

CASA de 7 mil cruzeiros. Habitat, São Paulo, no3, abr-jun 1951, p.4-5

CONSTRUIR é viver. Habitat, São Paulo, no7, abr-jun 1952, p.3-9

CERÂMICA do Nordeste. Habitat, São Paulo, no2, jan-mar 1951, p.72-74

CAMPELLO, Maria de Fátima de M. B. Lina Bo Bardi: a casa moderna e a cabana primitiva. In: Docomomo Bahia: 50 anos de Lina Bo B ardi na Encruzilhada da Bahia e do Nordeste, 2009, Salvador. Disponível em: <http://www.docomomobahia.org/linabobardi_50/14.pdf> Acesso em: 15 mar. 2013

CZERNA, Renato Cirell. Carta a berta. Habitat, São Paulo, nํ3, abr-jun 1951, p.1

DE GIORGI, Manolo. Vicissitudes of the 1940s. In: FIELL, Peter; FIELL, Charlotte (org.). Domus, vol.I, 1928-1939. Koln: Taschen, 2006. p.11

EX-VOTOS do nordeste. Habitat, São Paulo, no1, out-dez 1950, p.72

FERRARA, Lucrécia D'Aléssio. A ciência do olhar atento. Trans/Form/Ação, Marília, v. 9-10, p. 01-07, Jan. 1987. Disponível em: <http://www.scielo.br/scielo.php?script=sci_arttext\&pid=S0101$31731987000100001 \& \operatorname{lng}=e n \& n r m=i s o>$

FIELL, Peter; FIELL, Charlotte (org.). Dom us, vol.I, 1928-1939. Koln: Taschen, 2006.

HABITAT: REVISTA DAS ARTES NO BRASIL. São Paulo, no 1-15, 1950-1954

MóVEIS novos. Habitat, São Paulo, no1, out-dez 1950, p.53-59 
NOSSOS instrumentos musicais. Habitat, São Paulo, no7, abr-jun 1952, p.42

O POVO é arquiteto. Habitat, São Paulo, no10, jan-mar 1953, p.52

PAGANO, Giuseppe. Arquitettura rurale in Italia. Casabella, Milão, no 96, dez. 1935, p. 16-23 . Case Rurale. Casabella, Milão, no 86, fev. 1935, p. 8-15 . Documentti di Architettura Rurale. Casabella, Milão, no95, 1935, p.18-25 . Struttura e architettura. In: Dopo Sant'Elia. Milão: Domus, 1935, p.37-119

POR uma enciclopédia brasileira. Habitat, São Paulo, out-dez no9, 1952, p.1

PORQUE o povo é arquiteto? Habitat, São Paulo, no3, abr-jun 1951, p.3

PREFÁCIO. Habitat, São Paulo, no1, out-dez 1950, p.1

SIMIONATTO, Ivete. Cadernos do cárcere. Revista Brasileira de Ciências Sociais. São Paulo, v. 17, no 48, p. 212-215, fev. 2002. Disponível em: <http://www.scielo.br/scielo.php?script=sci_arttext\&pid=S010269092002000100016\&lng=en\&nrm=iso> Acesso em: 23 nov. 2015

\section{LIVROS}

ADAMSON, Walter L. Futurism and Italian Intervention in World Wa r I. In: GREENE, Vivien (org.). Italian Futurism 1909-1944: reconstructing the universe. New York: Guggenheim Museum Publications, 2014. p.175-183

ARGAN, Giulio Carlo. Arte Moderna: do Iluminismo aos movimentos contemporâneos. São Paulo: Companhia da Letras,1992.

1993. História da arte como história da cidade. São Paulo: Martins Fontes,

BAKHTIN, Mikhail. A cultura popular na Idade Média: o contexto de François Rabelais. São Paulo: HUCITEC / Editora UNB, 2008

BARDI, Lina Bo. Contribuição propedêutica ao ensino da Teoria da Arquitetura. Tese apresentada ao Concurso da Cadeira de Teoria da Arquitetura na Faculdade de Arquitetura e Urbanismo da Universidade de São Paulo. São Paulo: Instituto Lina Bo e P. M. Bardi, 2002. Edição facsímile do original de 1957

BASTOS, Maria Alice Junqueira. Pós-Brasília: Rumos da Arquitetura Brasileira. São Paulo: Perspectiva, 2007

BASTOS, Maria Alice Junqueira; ZEIN, Ruth Verde. Brasil: arquiteturas após 1950. São Paulo: Perspectiva, 2010

BENEVOLO, Leonardo. A História da Arquitetura Moderna. Barcelona: Gustavo Gili, 2004 
BENJAMIN, Walter. A Obra de Arte na Era da reprodutibilidade técnica. In: Obras Escolhidas. São Paulo: Brasiliense, 1994, p.165-196

BRUAND, Yves. Arquitetura contemporânea no Brasil. São Paulo: Editora Perspectiva, 2002

COHEN, Jean-Louis. O futuro da arquitetura desde 1889: Uma história mundial. São Paulo: Cosac Naify, 2013

COSTA, L. Registro de u ma vivência. São Paulo: Empresa das Artes, 1995

DE FUSCO, Renato. La idea de arquitectura - historia de la critica desde Viollet-le-duc a Persico. Barcelona: Editorial Gustavo Gili, 1976 [1968]

DEBENEDETTI, E. ; SALMONI, A. Arquitetura italiana em São Paulo. São Paulo: Instituto Cultural ítalo-Brasileiro, 1993

FERRARA, Lucrécia D’Aléssio. Estratégia dos signos. São Paulo: Perspectiva, 1986

FERRAZ, Marcelo (Coord.), Instituto Lina Bo e P.M. Bardi. Lina Bo Bardi. São Paulo: Empresa das Artes, 1993

FERRAZ, Marcelo Carvalho; LATORRACA, Giancarlo (Orgs.). Igreja Espírito Santo do Cerrado . São Paulo; Lisboa, Blau, Instituto Lina Bo e P.M. Bardi, 1999.

FRAMPTON, Kenneth. História crítica da arquitetura moderna. São Paulo: Martins Fontes, 1997

GREENE, Vivien (org.). Italian Futurism 1909-1944: reconstructing the universe. New York: Guggenheim Museum Publications, 2014

HOLLANDA, Heloisa B. de; GONÇALVES, Marcos A. Cultura e participação nos anos 60 . São Paulo: Brasiliense, 1982. Coleção Tudo é história, no41

LATORRACA, Giancarlo (org.). Cidadela da liberdade. São Paulo: Instituto Lina Bo e P.M. Bardi, 1999

LE CORBUSIER. Por u ma arquitetura. Estudos. São Paulo: Perspectiva, 1973

MEYER, Esther da Costa. Drawn into the Future: Urban Vision by Mario Chiattone and Antonio Sant'Elia. In: GREENE, Vivien (org.). Italian Futurism 1909-1944: reconstructing the universe. New York : Guggenheim Museum Publications, 2014. p.141-155

OLIVEIRA, Olívia. Lina Bo Bardi: Obra construída. Buit work. Barcelona: Gustavo Gilli, 2014

Lina Bo Bardi: Sutis substâncias da arquitetura. São Paulo, Barcelona: Romano Guerra, Gustavo Gilli, 2006

PEREIRA, Juliano. Lina Bo Bardi. BAHIA, 1958 - 1964. Uberlândia, EDUFU, 2008

RIBEIRO, Darcy. O povo brasileiro: a formação e o sentido do Brasil. São Paulo: Companhia das Letras, 2012 
RICOUER, P. História e verdade: civilização universal e culturas nacionais. Rio de Janeiro: Forense, 1968 RISÉRIO, Antônio. Avant-garde na Bahia. São Paulo: Instituto Lina Bo e P.M. Bardi, 1995

RUBINO, Silvana; GRINOVER, Marina (Org). Lina por escrito: textos escolhidos de Lina Bo Bardi. São Paulo: Cosac Nayfi, 2009

SABATINO, Michelangelo. Pride in Modesty: modernist architecture and the vernacular tradition in Italy. Toronto: University of Toronto Press, 2012.

SALARIS, Claudia. The invention of the programmatic avant-garde. In: GREENE, Vivien (org.). Italian Futurism 1909-1944: reconstructing the universe. New York: Guggenheim Museum Publications, 2014. p. 22-49

STRINATI, Domenic. Cultura popular. Uma introdução. São Paulo: Editora Hedra, 2000

SUZUKI, M. (Coord.). Tempos de Grossura: o Design no Impasse. São Paulo: Instituto Lina Bo e P. M. Bardi, 1994

VELOSO, Caetano. Verdade Tropical. São Paulo: Companhia das Letras, 1997.

ZEVI, Bruno. Saber ver arquitetura. São Paulo: Martins Fontes, 1996

\section{SITES}

ITAÚ Cultural. Enciclopédia Itaú Cultural. Mestre Vitalino. Disponível em: <http://enciclopedia.itaucultural.org.br/pessoa9523/mestre-vitalino> Acesso em: 03 de janeiro de 2015

MARTINS, Maria Lúcia. Augusto Rodrigues: um educador com arte. Educação Pública. Disponível em: <http://www.educacaopublica.rj.gov.br/biblioteca/educacao/0069_09.html> Acesso em: 03 de janeiro de 2015

ICOM Internacional. Preservação e divulgação do patrimônio natural e cultural mundial, do presente e do futuro, tangível e intangível. Portugal, 2015. Disponível em: <http://www.icom-portugal.org/pagina,123,152.aspx> Acesso em 05 de janeiro de 2015 